\title{
Supported Liquid Catalysts for Removal of High Temperature Fuel Cell
} Contaminants

\author{
Final Report \\ Start Date: October 1, 1998 \\ End Date: September 30, 1999 \\ Alan W. Weimer (PI), Peter Czerpak, and Patrick Hilbert \\ Department of Chemical Engineering \\ University of Colorado \\ Boulder, CO 80309-0424 \\ sumo
}

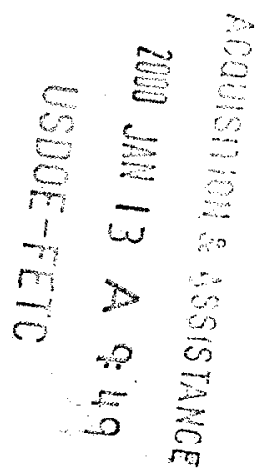

Report Issued: January, 2000

Final Report: DE-FG26-98FT40122 


\section{DISCLAIMER}

Portions of this document may be illegible in electronic image products. Images are produced from the best available original document. 


\section{Disclaimer}

This report was prepared as an account of work sponsored by an agency of the United States Government. Neither the United States Government nor any agency thereof, nor any of their employees, makes any warranty, express or implied, or assumes any legal liability or responsibility for the accuracy, completeness, or usefulness of any information, apparatus, product, or process disclosed, or represents that its use would not infringe privately owned rights. Reference herein to any specific commercial product, process, or service by trade name, trademark, manufacturer, or otherwise does not necessarily constitute or imply its endorsement, recommendation, or favoring by the United States Government or any agency thereof. The views and opinions of authors expressed herein do not necessarily state or reflect those of the United States Government or any agency thereof. 


\section{Abstract}

A novel catalytic synthesis gas oxidation process using molten carbonate salts supported on compatible fluidized iron oxide particles ("supported-liquid-phase-catalyst" (SLPC) fluidized bed process) was investigated. This process combines the advantages of large scale fluidized bed processing with molten salt bath oxidation. Molten salt catalysts can be supported within porous fluidized particles in order to improve mass transfer rates between the liquid catalysts and the reactant gases. Synthesis gas can be oxidized at reduced temperatures resulting in low $\mathrm{NO}_{\mathrm{x}}$ formation while trace sulfides and halides are captured in-situ. Hence, catalytic oxidation of synthesis gas can be carried out simultaneously with hot gas cleanup. Such SLPC fluidized bed processes are affected by inter-particle liquid capillary forces that may lead to agglomeration and de-fluidization of the bed. An understanding of the origin and strength of these forces is needed so that they can be overcome in practice.

Process design is based on thermodynamic free energy minimization calculations that indicate the suitability of eutectic $\mathrm{Na}_{2} \mathrm{CO}_{3} / \mathrm{K}_{2} \mathrm{CO}_{3}$ mixtures for capturing trace impurities in-situ $\left(<1 \mathrm{ppm} \mathrm{SO}_{\mathrm{x}}\right.$ released) while minimizing the formation of $\mathrm{NO}_{\mathrm{x}}(<10 \mathrm{ppm})$. Iron oxide has been identified as a preferred support material since it is non-reactive with sodium, is inexpensive, has high density (i.e. inertia), and can be obtained in various particle sizes and porosities. Force balance modeling has been used to design a surrogate ambient temperature system that is hydrodynamically similar to the real system, thus allowing complementary investigation of the governing fluidization hydrodynamics.

The primary objective of this research was to understand the origin of and to quantify the liquid capillary interparticle forces affecting the molten carbonate SLPC fluidized bed process. Substantial theoretical and experimental exploratory results indicate process feasibility. The potential environmental gain from success is enormous, impacting all areas of the world where coal is burned to supply steam or direct industrial heat. Project success may lead to an integrated combustion system providing for simultaneous catalytic oxidation and hot gas cleanup of raw synthesis gas from an upstream coal gasifier. 


\section{Table of Contents}

I. Executive Summary 5

II. Introduction 6

A. Problem Statement $\quad 6$

$\begin{array}{ll}\text { B. Objectives } & 7\end{array}$

III. Background Science $\quad 7$

A. Supported Liquid Phase Molten Salt Catalysis 7

B. Fluidized Bed Considerations $\quad 8$

IV. Experimental Results and Discussion $\quad 8$

A. Viable Support Materials Selection $\quad 8$

B. Trace Contaminant Capture 9

C. Fluidization of Supported Molten Salt 10

D. Force Balance Analysis 13

E. Surrogate System Design 14

V. Summary and Conclusions 19

$\begin{array}{ll}\text { VI. Nomenclature } & 20\end{array}$

VII. References $\quad 21$

Appendix A (Thermodynamic Modeling) 26

Appendix B (Experimental Procedures and Results) 111

\section{List of Graphical Materials}

Figure 1. SLP Molten Salt Fluidized Bed Catalytic Combustor with In-situ Hot Gas Cleanup $\quad 6$

Figure 2. Supported Liquid Phase Catalyst (SLPC) 7

Figure 3. Effect of $\mathrm{LiNO}_{3}$ Addition on Fluidization for Non-porous Particles 11

Figure 4. Effect of $\mathrm{LiNO}_{3}$ Addition on Fluidization for Porous Particles 11

Figure 5. Designed Experiment Results for Molten $\mathrm{LiNO}_{3}$ Loading 12

Figure 6. Pendular Liquid Bridge Between Two Spherical Particles 13

Figure 7. Fluidized Bed Apparatus for Liquid-Capillary Force Balance Studies 15

Figure 8. Laser Imaging System Interfaced to Current laboratory Fluid Bed 16

Figure 9. Using the Pulsed Laser for Real Time Imaging of Fluidization Process 17

Figure 10. Visisizer Output for Measured Particle Size Distribution $\quad 18$ 


\section{Executive Summary}

An investigation was carried out for the use of supported molten salt catalysts to (1) selectively capture trace contaminants in synthesis gas being fed to fuel cells (without oxidation) and (2) to simultaneously combust/cleanup hot synthesis gas being fed to a fluidized bed combustor. The first application is directed towards hot gas cleanup without oxidation while the second is directed towards hot gas cleanup with simultaneous oxidation, both applications using supported molten salt. In both instances, thermodynamic free energy minimization studies were carried out in order to evaluate the effectiveness of the molten salt. Studies focused on both the possible reaction with certain fluidized solid support materials and the ability to effectively capture trace contaminants in the synthesis gas stream. Experimental studies were also carried out to evaluate the ability to support molten salt on fluidized particles. Theoretical force balance studies complemented the experimental work and provided an understanding of the inter-particle forces that need to be overcome in practice.

Thermodynamic calculations indicated that certain molten salt catalyst support materials such as $\mathrm{Fe}_{2} \mathrm{O}_{3}, \mathrm{ZrO}_{2}$, and $\mathrm{CaO}$ were non-reactive and, hence, compatible with molten carbonate salts. However, the studies also indicated that it was difficult, if not impossible, to capture trace contaminants without oxidizing the synthesis gas. Details regarding the thermodynamic studies are reported in Appendix A.

Experimental studies focused on "proof-of-concept" experiments with regard to the feasibility of fluidizing support particles in the presence of a liquid molten salt. It was found that porous particles that could contain molten salt within the particles could be fluidized with the molten salt content approaching $10 \mathrm{wt} \%$. It was also found that larger particles could support more salt than finer particles. Details regarding the experimental studies are reported in Appendix B.

Theoretical force balance studies focused on an understanding of the liquid capillary interparticle forces controlling the process hydrodynamics. An expression was derived that accounted for such forces in a supported liquid phase catalyst (SLPC) process. Inertial forces and surface tension forces were found to be important. It is essential that inertial forces overcome surface tension forces in order to maintain fluidization in the bed. Hence, the theoretical development explained why larger more dense particles that were porous were best at supporting liquids in fluidized systems. A surrogate ambient temperature system was designed based upon these results. Some preliminary results with the surrogate system are presented.

. In general, it was found from the thermodynamic free energy minimization studies that trace contaminants in synthesis gas could not be captured independent of oxidation using supported molten salts. Hence, the original intention of using a molten salt SLPC system for removal of high temperature fuel cell contaminants did not appear feasible since the synthesis gas would ultimately oxidize. In view of this, the project focused on the possibility of using molten carbonate SLPC processes for simultaneous low temperature oxidation processing and hot gas cleanup.

The body of this report is concerned with presenting the summarized results for the feasible case of using a supported molten carbonate eutectic salt mixture $\left(\mathrm{Na}_{2} \mathrm{CO}_{3} / \mathrm{K}_{2} \mathrm{CO}_{3}\right)$ as a selective oxidizer for synthesis gas oxidation and simultaneous hot gas cleanup. A product gas containing less than $1 \mathrm{ppm} \mathrm{SO}$ and $<10 \mathrm{ppm} \mathrm{NO}$ can be obtained for such a process. The appendices can be referred to for details and are self-contained with their own references. Although the results presented here are very encouraging and support further research in the area, they are preliminary. A Provisional Patent Application has been filed for this novel process. 


\section{Introduction}

A novel method allowing the selective oxidation of synthesis gas at reduced temperatures with almost no $\mathrm{NO}_{\mathrm{x}}, \mathrm{SO}_{\mathrm{x}}$, or halide emissions is to use a molten salt oxidation catalyst supported by particles in a fluidized bed (Figure 1). This large-scale method for reduced temperature selective oxidation, with simultaneous in-situ capture of trace contaminants ( $\mathrm{S}, \mathrm{Cl}$ species, etc.), is one in which catalytic molten salt (e.g. $\mathrm{Na}_{2} \mathrm{CO}_{3} / \mathrm{K}_{2} \mathrm{CO}_{3}$ eutectic mixtures) oxidation is carried out within the pores of compatible fluidized support particles. Such a process combines the advantages of fluidized bed combustion and molten salt bath oxidation. It takes advantage of the large fluidized bed particle surface area and increased residence time (over a conventional molten salt bath) to provide for increased mass transfer rates per unit volume of the reactor between active salt surfaces and combustible species. The potential environmental gain from success is enormous, impacting all areas of the world where synthesis gas is produced from coal and burned to supply electricity. Project success may lead to an integrated combustion system providing for simultaneous catalytic oxidation and hot gas cleanup of raw synthesis gas from an upstream coal gasifier.

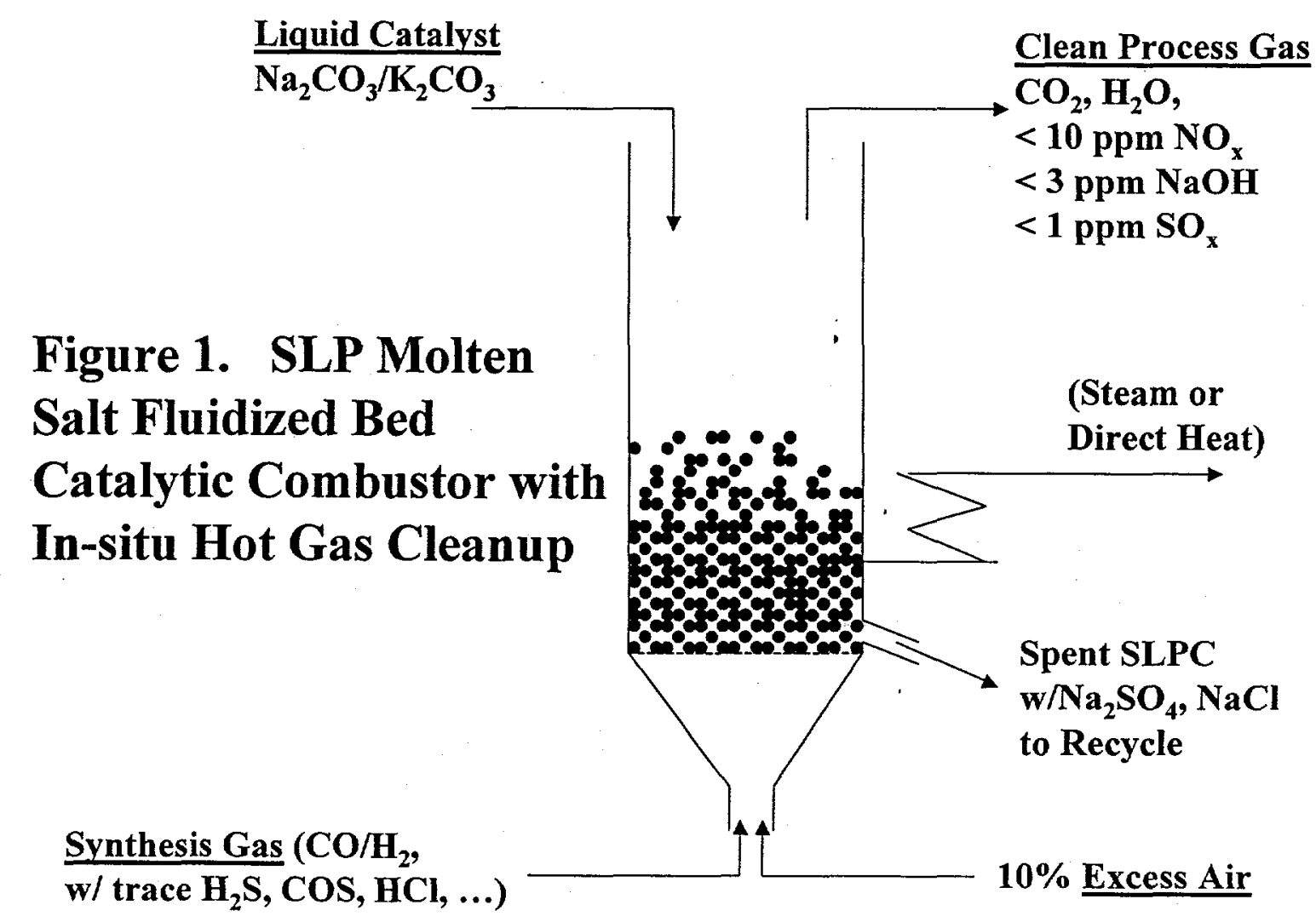

\section{A. Problem Statement}

The primary concern with this process is the fluidizability of particles in the presence of a supported molten salt both without and with reaction occurring. Hence, a focus of this research is an understanding of the liquid capillary forces affecting the fluidization of such support particles. 


\section{B. Objectives}

The research involves substantial exploratory theoretical (thermodynamic free energy minimization calculations for selecting suitable particle support materials and molten salts; particle force balance calculations for understanding governing inertial and liquid capillary forces) and experimental ("proof of concept" experiments demonstrating the fluidization of particles supporting molten salts) results that indicate process feasibility. A surrogate system has also been designed that allows fluidization hydrodynamics to be investigated at ambient temperature. The surrogate system is hydrodynamically similar to the real system. The objective of the research is a basic understanding of the liquid capillary forces controlling fluidization of the supported molten carbonate fluidized bed process.

\section{Background Science}

\section{A. Supported Liquid Phase Molten Salt Catalysis}

Molten salts have been used to catalyze various oxidation reactions ${ }^{1-5}$. Most non-charged materials are soluble in molten salts. This solubility is probably related to the crystal structure of salts in the molten state. Data from X-rays taken at temperatures above their melting point indicate that molten salts still retain a quasi-lattice structure. The solubility of the reactants (solute) in the molten salt is based on the theory that the solute assumes an electronic charge in the semi-crystalline melt. This charge gives the solute an electrostatic orientation similar to the ionic component of the molten salt. The process of polarizing or orienting the normally neutral species results in a reduction of the energy required to initiate and sustain chemical reactions. In addition, there are substantial decreases in the unburned hydrocarbon products $^{6}$ relative to conventional oxidation. Molten carbonates, such as $\mathrm{Na}_{2} \mathrm{CO}_{3}$ and $\mathrm{K}_{2} \mathrm{CO}_{3}$, have been particularly active in simultaneously capturing trace sulfides and halides that react with the salt and are retained in the melt as inorganic salts rather than released to the atmosphere as volatile gases ${ }^{7-11}$.

One of the possibilities to heterogenize a homogeneously catalyzed (liquid) reaction system is the use of SLPCs ${ }^{12-16}$. SLP catalysis is the coating of a porous support particle's pores with a catalytically

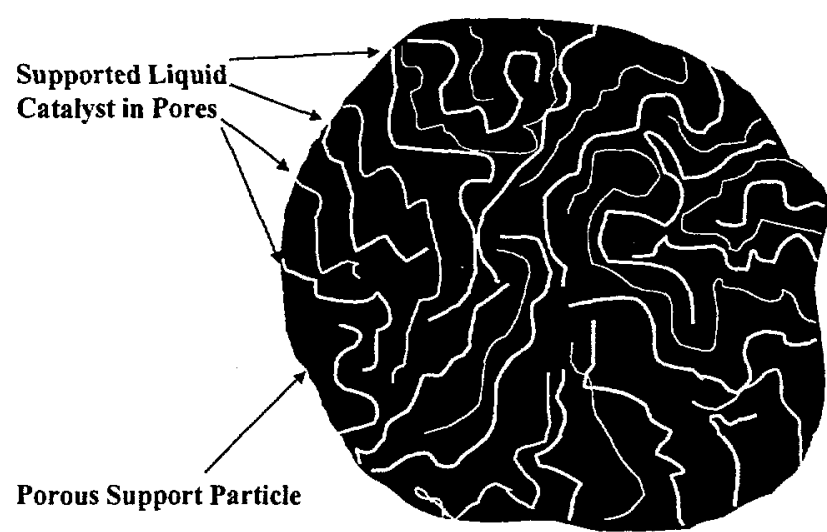

Figure 2. Supported Liquid Phase Catalyst (SLPC) active liquid to catalyze gas phase reactions (Figure 2). These hybrid contacts have the advantage, compared to a homogeneously catalyzed reaction in a liquid/gas reaction system (e.g. bubble column reactor or, for this work, a molten salt bath), to make possible a much larger gas/liquid exchange area per unit volume of the reactor, as well as a reduction of the educt's path length in the catalyst solution. 
There have only been three studies reported for SLPC molten salt systems (all in fixed bed systems): (1) the hydrodechlorination of $\mathrm{CCl}_{4}$ with $\mathrm{H}_{2}$ over several silica-supported $\mathrm{PdCl}_{2}$-containing molten salt catalysts ${ }^{17}$, (2) the dissociation of methanol to synthesis gas over supported molten $\mathrm{Cu}-\mathrm{Cl}-$ $\mathrm{KCl}$ or $\mathrm{CuCl}-\mathrm{ZnCl}_{2}-\mathrm{KCl}$ on $\mathrm{SiO}_{2}, \mathrm{Al}_{2} \mathrm{O}_{3}$, and $\mathrm{ZnSiO}_{3}$ supports ${ }^{18}$ and (3) the catalytic oxidation of diesel exhaust particulates over various supported binary eutectic salt mixtures ${ }^{19}$.

\section{B. Fluidized Bed Considerations}

Compared to fixed beds, fluidized bed reactors are most suitable for the performance of a SLP-catalyzed reaction because of their inherent isothermal behavior, high volumetric throughputs, and very large surface area for reaction provided by the fluidized particles ${ }^{20}$. The suitability for SLP catalyzed reactions has been demonstrated using a hydroformylation reaction catalyzed by an $\mathrm{Rh}$ complex dissolved in di-Me glycol phthalate on a fluidized alumina support ${ }^{21-27}$. Although fluidization of support particles with liquid loadings has been demonstrated, a critical need is to understand the effect of liquid loading, liquid properties, support particle properties and fluidized bed hydrodynamics on the tendency of the fluidized bed to defluidize, the result of particle agglomeration. ${ }^{28-30}$. It is particularly crucial to understand these effects for the particular system of interest, supported molten carbonate salts on compatible particles at reaction conditions.

The presence of a molten salt liquid phase dispersed within a solid phase support powder induces undesirable agglomerative effects resulting from liquid capillary forces between the particles. Extensive exploratory work presented below indicates that suitable support particles can be fluidized in the presence of a substantial loading of molten salt. The support particles must be non-reactive with the molten salt, must have internal porosity to contain the SLPC internally, and must have substantial inertia (size, density, and velocity) to overcome agglomerative surface forces.

\section{Experimental Results and Discussion}

There is no previous work (other than the preliminary results to be presented here) in which molten salt has been investigated for use as an SLPC for fluidized particles. Our preliminary studies have focused on (1) selecting suitable support materials for the molten carbonates, (2) thermodynamic calculations to assess the capture of trace contaminants for these systems, (3) high temperature "proof-of-concept" fluidization studies to assess the viability of fluidization in the presence of a SLP molten salt, (4) particle force balance modeling to develop an understanding of the preliminary experimental results, and (5) design of a hydrodynamically similar surrogate system to allow ambient temperature studies.

\section{A. Viable Support Material Selection}

A support material must be selected that is low cost and compatible with $\mathrm{Na}_{2} \mathrm{CO}_{3} / \mathrm{K}_{2} \mathrm{CO}_{3}$ and raw coal gasifier product gases at typical gasifier outlet temperatures, i.e. $815^{\circ} \mathrm{C}(1088 \mathrm{~K})$. Since fluidized bed coal combustion processes typically use fluidizable $\mathrm{SiO}_{2}(500$ to $1000 \mu \mathrm{m}$ average particle size) particles and since spray dried $\mathrm{Al}_{2} \mathrm{O}_{3}$ is readily available and used extensively for fluidized bed catalytic processes (such as fluidized catalytic cracking, FCC), a first inclination would be to extend the use of these materials to the SLP carbonate catalyst systems. However, for coal 


\section{Table 1. Free Energy Minimization Products (Reactivity of $\mathrm{Na}_{2} \mathrm{CO}_{3}$ with SLPC Support Materials) \\ $T=1100 \mathrm{~K}$ \\ (1 mole $\mathrm{Na}_{2} \mathrm{CO}_{3}+9$ moles Support $\rightarrow$ Products)}

$\underline{\text { Support }}$

\section{Gaseous Products}

1 mole $\left(\sim 100 \% \mathrm{CO}_{2}\right)$

$\mathrm{SiO}_{2}$

$\mathrm{Al}_{2} \mathrm{O}_{3}$

\section{Other Products}

$19 / 3{\text { mole } \mathrm{SiO}_{2}}_{1} ; 1 / 3$ mole $\mathrm{Na}_{6} \mathrm{Si}_{8} \mathrm{O}_{19}$

$\mathrm{SiC}$

None

8 moles $\beta$-SiC; 2 moles $\mathrm{C} ; 1$ mole $\left(\mathrm{Na}_{2} \mathrm{O}\right)\left(\mathrm{SiO}_{2}\right)$ $\mathrm{Na}_{2} \mathrm{CO}_{3}+9 \mathrm{SiC} \rightarrow 8 \mathrm{SiC}+2 \mathrm{C}+\left(\mathrm{Na}_{2} \mathrm{O}\right)\left(\mathrm{SiO}_{2}\right)$

$\mathrm{ZrO}_{2}$

None

(No Reaction Products @ $1100 \mathrm{~K}$ )

1 mole $\mathrm{Na}_{2} \mathrm{CO}_{3} ; 9$ moles $\mathrm{ZrO}_{2}$

$\mathrm{Fe}_{2} \mathrm{O}_{3}$

None

(No Reaction Products@1100 K)

1 mole $\mathrm{Na}_{2} \mathrm{CO}_{3} ; 9$ moles $\mathrm{Fe}_{2} \mathrm{O}_{3}$

None

$\mathrm{CaO}$ (No Reaction Products @1100 K)

1 mole $\mathrm{Na}_{2} \mathrm{CO}_{3} ; 9$ moles $\mathrm{CaO}$

combustion systems, sodium (Na) salts are "sticky" and have been reported to create problems in fluidized bed boilers ( $\mathrm{SiO}_{2}$ based fluidization) fed with high $\mathrm{Na}$ content coal ${ }^{31,32}$. In order to address this concern, preliminary free energy minimization calculations using the $\mathrm{F}^{*} \mathrm{~A}^{*} \mathrm{C}^{*} \mathrm{~T}$ (Facility for the Analysis of Chemical Thermodynamics) software ${ }^{33}$ were carried out in order to screen potential support materials by evaluating equilibrium products for various $\mathrm{Na}_{2} \mathrm{CO}_{3}$ /support material systems at $\mathrm{T}=1100 \mathrm{~K}$ and $\mathrm{P}=1 \mathrm{~atm}$. Some of the results are summarized in Table 1. Clearly, $\mathrm{SiO}_{2}, \mathrm{Al}_{2} \mathrm{O}_{3}$, and $\mathrm{SiC}$ are reactive with $\mathrm{Na}_{2} \mathrm{CO}_{3}$ and, hence, are not suitable catalyst supports for the system of interest. Sodium carbonate $\left(\mathrm{Na}_{2} \mathrm{CO}_{3}\right)$ reacts with $\mathrm{SiO}_{2}$ to produce sodium silicate $\left(\mathrm{Na}_{6} \mathrm{Si}_{8} \mathrm{O}_{19}\right)$ and reacts with $\mathrm{Al}_{2} \mathrm{O}_{3}$ to produce $\beta$-alumina $\left(\mathrm{Na}^{*} \mathrm{Al}_{9} \mathrm{O}_{14}\right)$ as the thermodynamically stable products for these systems, respectively. Silicon carbide ( $\mathrm{SiC}$ ) was looked at as a possible high temperature stable species, however, preliminary thermodynamic calculations indicate the formation of sodium metasilicate $\left[\left(\mathrm{Na}_{2} \mathrm{O}\right)\left(\mathrm{SiO}_{2}\right)\right]$ as the stable product. This investigation indicates that $\mathrm{Fe}_{2} \mathrm{O}_{3}, \mathrm{CaO}$, and $\mathrm{ZrO}_{2}$ are stable non-reactive materials in the presence of $\mathrm{Na}_{2} \mathrm{CO}_{3}$ at $\mathrm{T}=1100 \mathrm{~K}$. The $\mathrm{Fe}_{2} \mathrm{O}_{3}$ particles are readily available and low cost. $\mathrm{Fe}_{2} \mathrm{O}_{3}$ also has a high density $(5.28 \mathrm{~g} / \mathrm{cc})$ and can be obtained in relatively large particle sizes with various internal porosities. Hence, $\mathrm{Fe}_{2} \mathrm{O}_{3}$ is a desirable fluidized bed support material for the SLP molten salt process.

\section{B. Trace Contaminant Capture}

Thermodynamic calculations have been extended to evaluate equilibrium product species for systems of raw coal gasifier (synthesis gas) product gases $/ 10 \%$ excess air, both without and with (Table 2) $\mathrm{Na}_{2} \mathrm{CO}_{3}$ /support materials being present at temperatures of 1100 and $1200 \mathrm{~K}$. It is clear in 
evaluating the equilibrium products of combustion for a typical gasifier using Illinois No. 6 coal (air feed) $/ 10 \%$ excess air $^{34}$ that $\mathrm{SO}_{\mathrm{x}}$ forms at large concentrations $(>$ $3000 \mathrm{ppm}$ ) for all temperatures and that the formation of $\mathrm{NO}_{\mathrm{x}}$ increases with increased temperature. Hence, a most desirable situation is one in which the complete combustion can be carried out at reduced temperatures (catalytic) where the resulting $\mathrm{NO}_{\mathrm{x}}$ concentration is low $(<10 \mathrm{ppm}$ for $\mathrm{T}<1100 \mathrm{~K})$ and where $\mathrm{SO}_{\mathrm{x}}$ formation is virtually $\mathrm{y}_{\infty}$. eliminated. Such a process appears viable from the preliminary free energy minimization results summarized in Table 2 . In this case, for combustion at temperatures less than approximately $1100 \mathrm{~K}$ and with $\mathrm{Na}_{2} \mathrm{CO}_{3}$ /support present at 1 mole $\mathrm{Na}_{2} \mathrm{CO}_{3}$ per 100 moles of gasifier product $(+10 \%$ excess air), the resulting $\mathrm{SO}_{\mathrm{x}}$ concentration is $<1 \mathrm{ppm}$ and $\mathrm{NO}_{\mathrm{x}}$ concentration is $<10 \mathrm{ppm}$ (see Table 2). As noted in earlier referenced studies with molten carbonates, typical molten salt bath combustion operating temperatures are well below $1100 \mathrm{~K}$, thus supporting low $\mathrm{NO}_{\mathrm{x}}$ concentrations. It is important to note (Table 2$)$ that volatile $\mathrm{NaOH}$ concentration will be low $(\approx 3 \mathrm{ppm}$ at $\mathrm{T}=1100 \mathrm{~K})$.

\section{Fluidization of Supported Molten Salt}

"Proof-of-concept" experiments demonstrated that porous support particles can be fluidized in the presence of substantial molten salt loadings (between 5 and $10 \mathrm{wt} \%$ ). These positive experimental results, along with a fundamental understanding of the governing force balances (i.e. liquid capillary vs. inertial, etc.) to be discussed below, provide motivation for surrogate system studies.

A high temperature fluidized bed reactor for the loading of particles with molten salts under fluidized conditions was designed, constructed, and instrumented for "proof-of-concept" fluidization studies ${ }^{35,36}$. The approach taken was to start out at low temperatures using a low melting temperature salt $\left(\mathrm{LiNO}_{3}, \mathrm{mp}=251^{\circ} \mathrm{C}[524 \mathrm{~K}]\right)$ supported on $\mathrm{SiO}_{2}$ and $\mathrm{Al}_{2} \mathrm{O}_{3}$. Fluidization studies were carried out initially for non-porous silica particles $(350,550,850,1100 \mu \mathrm{m}$; see Figure 3$)$ and then for porous alumina ( $450 \mu \mathrm{m}, \mathrm{SA}=318 \mathrm{~m}^{2} / \mathrm{g}$, Figure 4) and silica (110 to $227 \mu \mathrm{m}$, Figure 5) support particles at temperature up to $500^{\circ} \mathrm{C}$. Experiments were carried out to investigate the parameters needed to fluidize support particles in the presence of a substantial liquid loading of molten salt. A $7.5 \mathrm{~cm}$ diameter Inconel ${ }^{\mathrm{TM}}$ fluidized bed with a perforated plate distributor was constructed and placed within a vertical tube furnace for heating. Three hundred fifty grams $(350 \mathrm{~g})$ of support particles were fluidized with air. The bed was equipped with various differential pressure transmitters to study the fluidization of support particles. Minimum fluidization velocity was determined at ambient and operating temperature for every particle system. The addition of salt to the bed was carried out for superficial gas velocities, $u_{0}$, that ranged up to 3 times minimum, i.e. $u_{0} / u_{m f}=3$. The salt was added 


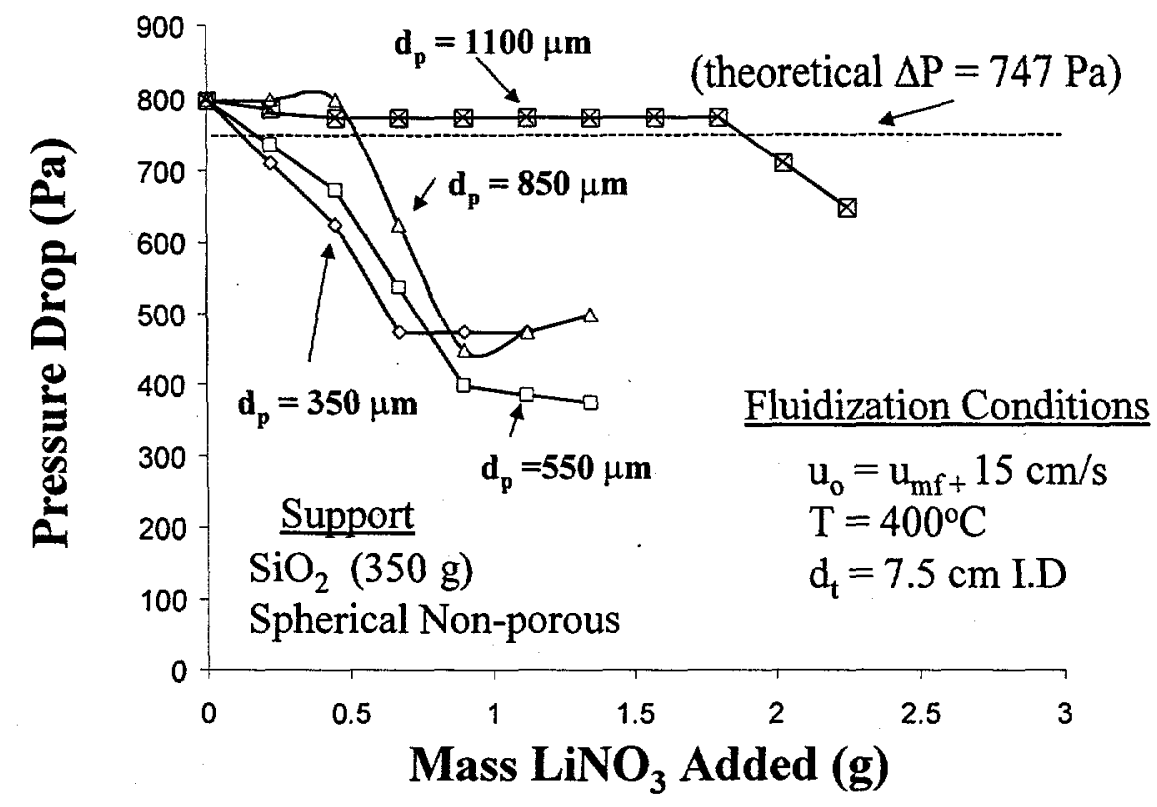

Figure 3. Effect of $\mathrm{LiNO}_{3}$ Addition on Fluidization for Non-porous Silica Particles $\left(T=400^{\circ} \mathrm{C}\right)$

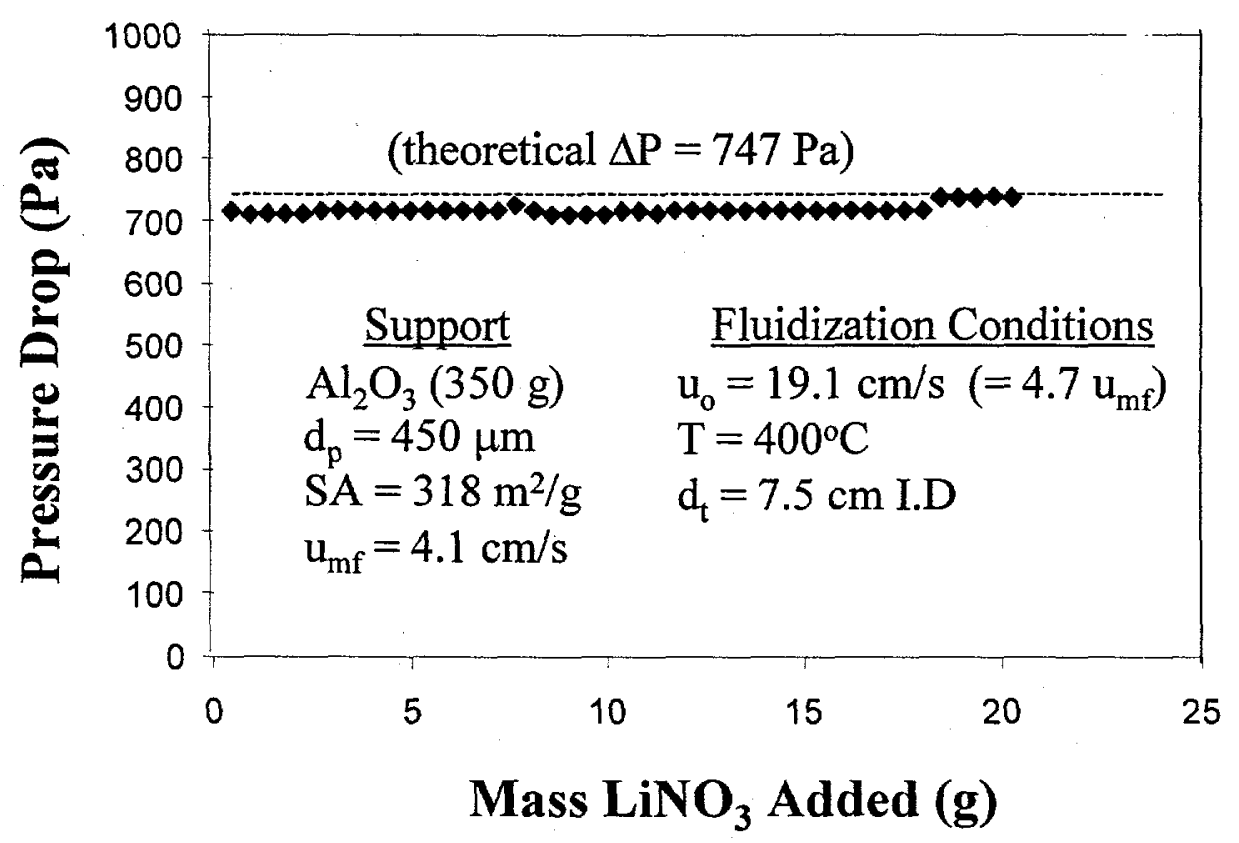

Figure 4. Effect of $\mathrm{LiNO}_{3}$ Addition on Fluidization for Porous Alumina Particles $\left(\mathrm{T}=\mathbf{4 0 0}^{\circ} \mathrm{C}\right)$ 
as a concentrated aqueous salt solution that was injected into the fluidized bed from above. The water flashed off with an initial decrease in bed temperature that quickly recovered within seconds. Material balances were carried out on the salt after each run. Inductively coupled plasma (ICP) analytical methods were used to verify the salt loading. For example, when using $\mathrm{LiNO}_{3}$ as the additive salt, Li concentration was measured by ICP in the spent support particles after the runs so as to verify its addition to the bed.

De-fluidization occurred almost immediately upon addition of salt to non-porous silica (glass beads) particles (Figure 3). The particles agglomerate and drop out of fluidization, resulting in a decreased bed pressure drop. It was found, however, that larger particles could maintain fluidization for increased salt loadings. Nonetheless, only $1.75 \mathrm{~g} \mathrm{LiNO}_{3}$ could be added per $350 \mathrm{~g}$ of support, even for $1100 \mu \mathrm{m}$ diameter particles.

Substantial $\mathrm{LiNO}_{3}\left(>20 \mathrm{~g} \mathrm{LiNO}_{3} / 350 \mathrm{~g}\right.$ support) could be loaded within the porous fluidized alumina support particles $\left(450 \mu \mathrm{m}, 318 \mathrm{~m}^{2} / \mathrm{g}\right.$, Figure 4$)$. The fluidization in the bed was maintained for over a week during this experiment. The experiment was shut down prior to any de-fluidization. These results clearly indicate that porous support particles are needed so the liquid phase can fill part

\section{Effect of Temperature, Gas Velocity, and Support on Critical Loading $\left(\mathrm{W}_{1} / \mathrm{W}_{\mathrm{B}}\right)$}

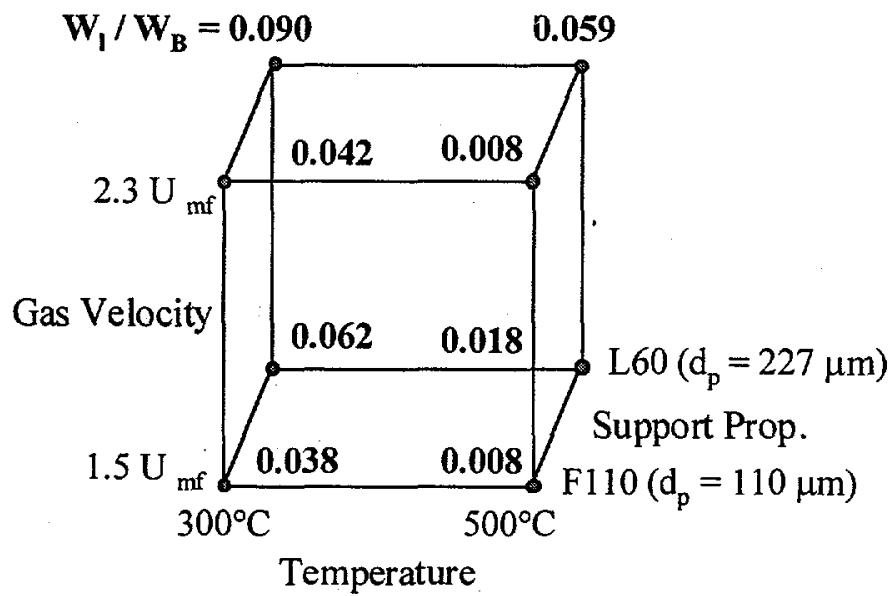

\section{Figure 5. Designed Experiment Results for Molten $\mathrm{LiNO}_{3}$ Loading}

of the internal pore volume while allowing the external agglomerative liquid capillary surface forces to be minimized.

A designed experiment (see Figure 5) was carried out to determine the effect of temperature $\left(300^{\circ} \mathrm{C}, 500^{\circ} \mathrm{C}\right)$, superficial gas velocity $\left(u_{\mathrm{o}} / \mathrm{u}_{\mathrm{mf}}=1.5,2.3\right)$, and support particle diameter $(110,227 \mu \mathrm{m}$ $\mathrm{SiO}_{2}$ ) on the amount of molten $\mathrm{LiNO}_{3}$ that could be loaded on the porous particles prior to defluidization. Salt loading values of up to $0.090 \mathrm{~kg}$ molten salt loading per $\mathrm{kg}$ bed support material 
(i.e. $\mathrm{W}_{\mathrm{l}} / \mathrm{W}_{\mathrm{B}}$ ) were sustained under fluidized conditions. Larger particles enable a correspondingly larger critical salt loading. This is because they have fewer surface contacts to form liquid bridges (smaller agglomerates formed) and higher separate particle kinetic energy when fluidized that enable the agglomerates to collide with more energy to break them apart. Increased gas velocity also correlates to having a higher particle kinetic energy. Elevated temperatures reduce the critical salt loading. The gas viscosity increases (smaller $\mathrm{N}_{\mathrm{Re}}$ ), which interacts with the decreasing liquid coating's surface tension and viscosity. It is believed that these competing phenomena cause the capillary forces due to liquid bridging to be smaller. Again, these results confirmed that porous support particles can be fluidized in the presence of a substantial liquid loading (almost $10 \%$ by mass).

\section{Force Balance Analysis}

A modified force balance is considered in order to better understand the experimental results. It accounts explicitly for liquid capillary cohesive forces between porous particles supporting liquids. The Ergun equation was developed as a correlation for determination of pressure drop in a nonflowing bed of particles ${ }^{37}$ :

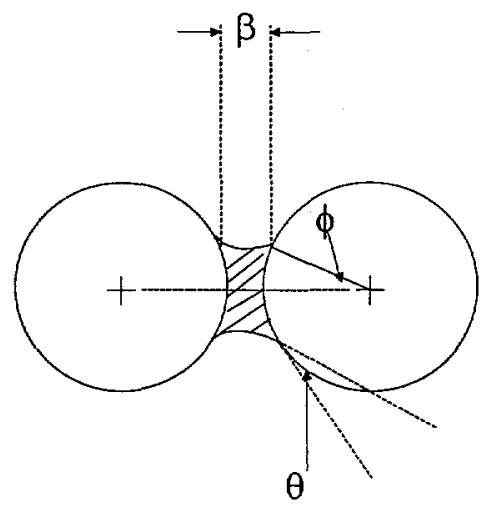

Figure 6. Pendular Liquid Bridge Between Two Spherical Particles

$$
\Delta \mathrm{P}\left(\mathrm{g}_{\mathrm{c}}\right) / 1=150\left(\left(1-\varepsilon_{\mathrm{mf}}\right)^{2} /\left(\phi_{\mathrm{s}}{ }^{2} \varepsilon_{\mathrm{mf}}{ }^{3}\right)\right) \mu_{\mathrm{g}} \mathrm{u}_{\mathrm{mf}} /\left(\mathrm{d}_{\mathrm{p}}{ }^{2}\right)+1.75\left(\left(1-\varepsilon_{\mathrm{mf}}\right) /\left(\phi_{\mathrm{s}} \varepsilon_{\mathrm{mf}}{ }^{3}\right)\right) \mathrm{u}_{\mathrm{mf}}{ }^{2} \rho_{\mathrm{g}} / \mathrm{d}_{\mathrm{p}}
$$

At the point of minimum fluidization, according to Wen and $\mathrm{Yu}^{38}$ :

$$
\Delta \mathrm{P}\left(\mathrm{g}_{\mathrm{c}}\right) / \mathrm{l}=\left(1-\varepsilon_{\mathrm{mf}}\right) \mathrm{g}\left(\rho_{\mathrm{p}}-\rho_{\mathrm{g}}\right)
$$

Wen and $\mathrm{Yu}^{38}$ equated these two equations and developed a relationship for calculating the minimum fluidization velocity, $u_{m f}$. However, for many systems operating at elevated temperatures, $u_{m f}$ of the particles departs from the traditional value due to a "stickiness" that develops between the particles ${ }^{39-}$ ${ }^{41}$. At this temperature, often referred to as the sintering temperature, interparticle forces ${ }^{42,43}$ become significant. Liss et al. ${ }^{44}$ added a cohesive force term accounting for a surface stress to equation (2):

$$
\Delta \mathrm{P}\left(\mathrm{g}_{\mathrm{c}}\right) / 1=\left(1-\varepsilon_{\mathrm{mf}}\right) \mathrm{g}\left(\rho_{\mathrm{p}}-\rho_{\mathrm{g}}\right)+6 \mathrm{~S}\left(1-\varepsilon_{\mathrm{mf}}\right) / \mathrm{d}_{\mathrm{p}}
$$

They carried out experiments to develop the cohesive number's, $N_{C_{o}}=6 \mathrm{~S} /\left(\left(\rho_{\mathrm{p}}-\rho_{\mathrm{g}}\right) \mathrm{d}_{\mathrm{p}} \mathrm{g}\right)$, dimensionless temperature functionality at minimum fluidization conditions.

In the case where a liquid phase is intentionally introduced into the bed of particles, a different expression for the cohesive force is needed. Research has shown that capillary forces ${ }^{45}$, when present, are typically an order of magnitude higher than van der Waals forces ${ }^{46-48}$, unless a separate liquid phase is introduced ${ }^{49,50}$ in which case they are much higher ${ }^{51}$. When this happens, only the interparticle forces due to the surface tension of the liquid need to be considered.

The cohesive force that results during a pendular state of liquid loading seen in Figure (6) for a fully wetting liquid (i.e. contact angle of zero) is a function of the liquid surface tension, particle 
diameter, and $\phi$ (the angle defining the size of the liquid bridge) seen in figure 6. Clift ${ }^{52}$ expresses this relationship for a smooth spherical surface as:

$$
F_{c}=\pi d_{p} \sigma[1 /(1+\tan (\phi)]
$$

Equation (4) does not account explicitly for liquid loading, q, i.e. liquid contained within the pores of porous fluidized support particles (a measure of the pore volume filled with liquid). By introducing the lumped parameter, $\psi=\psi(\mathrm{q}$, surface properties), equation (4) can be rewritten as:

$$
\mathrm{F}_{\mathrm{c}}=\pi \mathrm{d}_{\mathrm{p}} \sigma \psi
$$

Equation (5) is the cohesive force with units of force. It more explicitly accounts for SLPC surface properties via $\psi$.

If we divide $F_{c}$ by the volume of the sphere and $1 /\left(1-\varepsilon_{\mathrm{mf}}\right)$ we can derive an expression for the cohesive force per unit volume:

$$
F_{c} / V=6 \sigma \psi\left(1-\varepsilon_{m f}\right) / d_{p}^{2}
$$

Similar to the process used by Liss et $\mathrm{al}^{44}$, we now rewrite equation (3) as:

$$
\Delta \mathrm{P}\left(\mathrm{g}_{\mathrm{c}}\right) / 1=\left(1-\varepsilon_{\mathrm{mf}}\right) \mathrm{g}\left(\rho_{\mathrm{p}}-\rho_{\mathrm{g}}\right)+6 \sigma \psi\left(1-\varepsilon_{\mathrm{mf}}\right) \mathrm{g}_{\mathrm{c}} / \mathrm{d}_{\mathrm{p}}^{2}
$$

Equating equations (1) and (7) and rearranging we obtain:

$$
150\left(\left(1-\varepsilon_{\mathrm{mf}}\right) /\left(\phi_{\mathrm{s}}{ }^{2} \varepsilon_{\mathrm{mf}}{ }^{3}\right)\right) \mathrm{N}_{\mathrm{Re}}+\left(1.75 /\left(\phi_{\mathrm{s}} \varepsilon_{\mathrm{mf}}{ }^{3}\right)\right) \mathrm{N}_{\mathrm{Re}}{ }^{2}=\mathrm{N}_{\mathrm{Ga}}+6\left(\mathrm{~N}_{\mathrm{Re}} / \mathrm{N}_{\mathrm{Ca}}\right) \psi
$$

where:

$$
\begin{aligned}
& N_{G a}=\left(\rho_{g}\left(\rho_{p}-\rho_{g}\right) d_{p}^{3} g\right) / \mu_{g}^{2} \\
& N_{R e}=\rho_{g} u_{m f r} d_{p} / \mu_{g} \\
& N_{C a}=u_{m f} \mu_{g} /\left(\sigma g_{c}\right)
\end{aligned}
$$

\section{E. Surrogate System}

From the force balance relationship derived above, $\mathrm{N}_{\mathrm{Re}}, \mathrm{N}_{\mathrm{Ga}}$, and the ratio of $\mathrm{N}_{\mathrm{Re}} / \mathrm{N}_{\mathrm{Ca}}$ should be identical for the real and surrogate systems to be hydrodynamically similar. In addition, low vapor pressure liquids should be used so as to minimize volatile loss of liquid during the studies. Silicone oils are a desirable liquid for surrogate investigations ${ }^{53-55}$.

The targeted real process for investigation is one using $1 \mathrm{~mm} \mathrm{Fe}{ }_{2} \mathrm{O}_{3}$ support particles loaded with molten $\mathrm{Na}_{2} \mathrm{CO}_{3}$ at $950^{\circ} \mathrm{C}(1223 \mathrm{~K})$ being fluidized with a typical fuel gas $/ 10 \%$ excess air mixture (see Table 3). The calculated base surrogate system is one using $400 \mu \mathrm{m}$ silica support particles loaded with silicone oil at ambient temperature and fluidized with a 50/50 gas mixture of argon/nitrogen. The ambient temperature studies will evaluate the effect of varying particle porosity, $\varepsilon_{\mathrm{p}}$, and liquid loading, q on $\psi$. A comparison of the real and base surrogate systems is given in Table 
3. The surrogate system will allow ambient temperature experimentation for determining the functionality of $\psi$ in the real $\mathrm{Fe}_{2} \mathrm{O}_{3}$ supported molten $\mathrm{Na}_{2} \mathrm{CO}_{3}$ process.

It is important to note that this approach can be applied to an understanding of liquid capillary forces for SLPC systems in general. For example, $\mathrm{N}_{\mathrm{Re}}, \mathrm{N}_{\mathrm{Ga}}$, and $\mathrm{N}_{\mathrm{Re}} / \mathrm{N}_{\mathrm{Ca}}$ can be adjusted and fixed for different systems (systems other than the supported molten salt system).

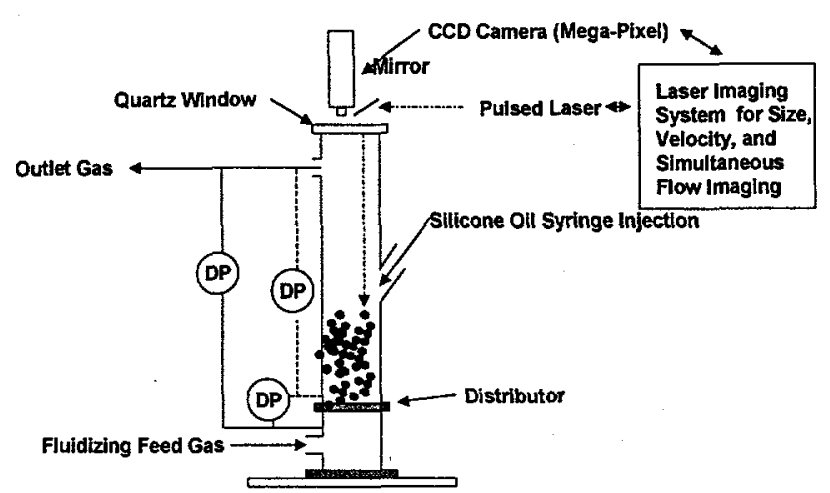

Figure 7. Fluidized Bed Apparatus for Liquid-Capillary Force Balance Studies Using Surrogate Silicone Oil/Silica System

\section{Table 3. Similarity Between Real System and Ambient Temperature Surrogate System}

\section{$\underline{\text { Real System }}$}

Particle Diameter, $d_{p}(m)$

Particle Density, $\rho_{\mathrm{p}}\left(\mathrm{kg} / \mathrm{m}^{3}\right)$

Gas Density, $\rho_{\mathrm{g}}\left(\mathrm{kg} / \mathrm{m}^{3}\right)$

Gas Viscosity, $\mu_{\mathrm{g}}(\mathrm{kg} / \mathrm{m}-\mathrm{s})$

Liquid Surface Tension, $\sigma(\mathrm{N} / \mathrm{m})$

Min. Fluidization Vel., $\mathrm{u}_{\mathrm{mf}}(\mathrm{m} / \mathrm{s})$

Temperature, $\mathrm{T}(\mathrm{K})$

Reynolds Number, $\mathrm{N}_{\mathrm{Re}}$

Galileo Number, $\mathrm{N}_{\mathrm{Ga}}$

Capillary Number, $\mathrm{N}_{\mathrm{Ca}}$

Ratio, $\mathrm{N}_{\mathrm{Re}} \mathrm{N}_{\mathrm{Ca}}$
$\begin{array}{cl}\mathrm{Fe}_{2} \mathrm{O}_{3} & ; 1 \times 10^{-3} \\ & ; 5280\end{array}$

Fuel Gas/Air; 0.26 " ; $4.77 \times 10^{-5}$

Molten $\mathrm{Na}_{2} \mathrm{CO}_{3} ; 0.206$

1

1223

5.45

5918

$2.315 \times 10^{-4}$

23530 $\underline{\text { Surrogate System }}$

\begin{tabular}{|c|c|}
\hline$\underset{4}{\mathrm{SiO}_{2}}$ & ; $4 \times 10^{-4}$ \\
\hline $\operatorname{Ar} / \mathrm{N}_{2}$ & $; 1.3$ \\
\hline Silicone & Oil; $1.65 \times 10^{-2}$ \\
\hline & \\
\hline
\end{tabular}

5.42

5905

$2.301 \times 10^{-4}$

23560

Surface tension effects at ambient temperature for other supported liquid systems can be studied by investigating bed behavior using different glycerin/water mixtures.

The primary objectives of this aspect of the research are (1) to understand the origin of the liquid capillary interparticle forces affecting a SLP molten salt fluidized bed process and (2) to quantify these forces so that they can be overcome in practice.

The liquid capillary forces originate from the supported liquid loaded in the pores of the support particles. $\psi$ can be quantified at minimum fluidization conditions from the governing force balance equation derived previously: 


$$
150\left(\left(1-\varepsilon_{\mathrm{mf}}\right) /\left(\phi_{\mathrm{s}}^{2} \varepsilon_{\mathrm{mf}}^{3}\right)\right) \mathrm{N}_{\mathrm{Re}}+\left(1.75 /\left(\phi_{\mathrm{s}} \varepsilon_{\mathrm{mf}}^{3}\right)\right) \mathrm{N}_{\mathrm{Re}}^{2}=\mathrm{N}_{\mathrm{Ga}}+6\left(\mathrm{~N}_{\mathrm{Re}} / \mathrm{N}_{\mathrm{Ca}}\right) \psi
$$

With $\psi$ determined, the liquid capillary forces can be quantified from our proposed liquid capillary force term for SLPC:

$$
\mathrm{F}_{\mathrm{c}}=\pi \mathrm{d}_{\mathrm{p}} \sigma \psi
$$

A $6.5 \mathrm{~cm}$ (2-1/2 inch) I.D. fluidized bed apparatus (made of quartz and Plexiglas ${ }^{\mathrm{TM}}$ ) (Figure 7) was constructed for the experimental program. Typical fluidization parameters such as expanded bed height, $\mathrm{L}_{\mathrm{f}}$, and the minimum fluidization velocity, $\mathrm{u}_{\mathrm{mf}}$, are measured by conventional differential pressure (DP) methods employing transmitters ${ }^{56}$. Three DP measurements are available: (1) across the distributor, (2) across the fluidized particles, and (3) across the distributor and fluidized particles.

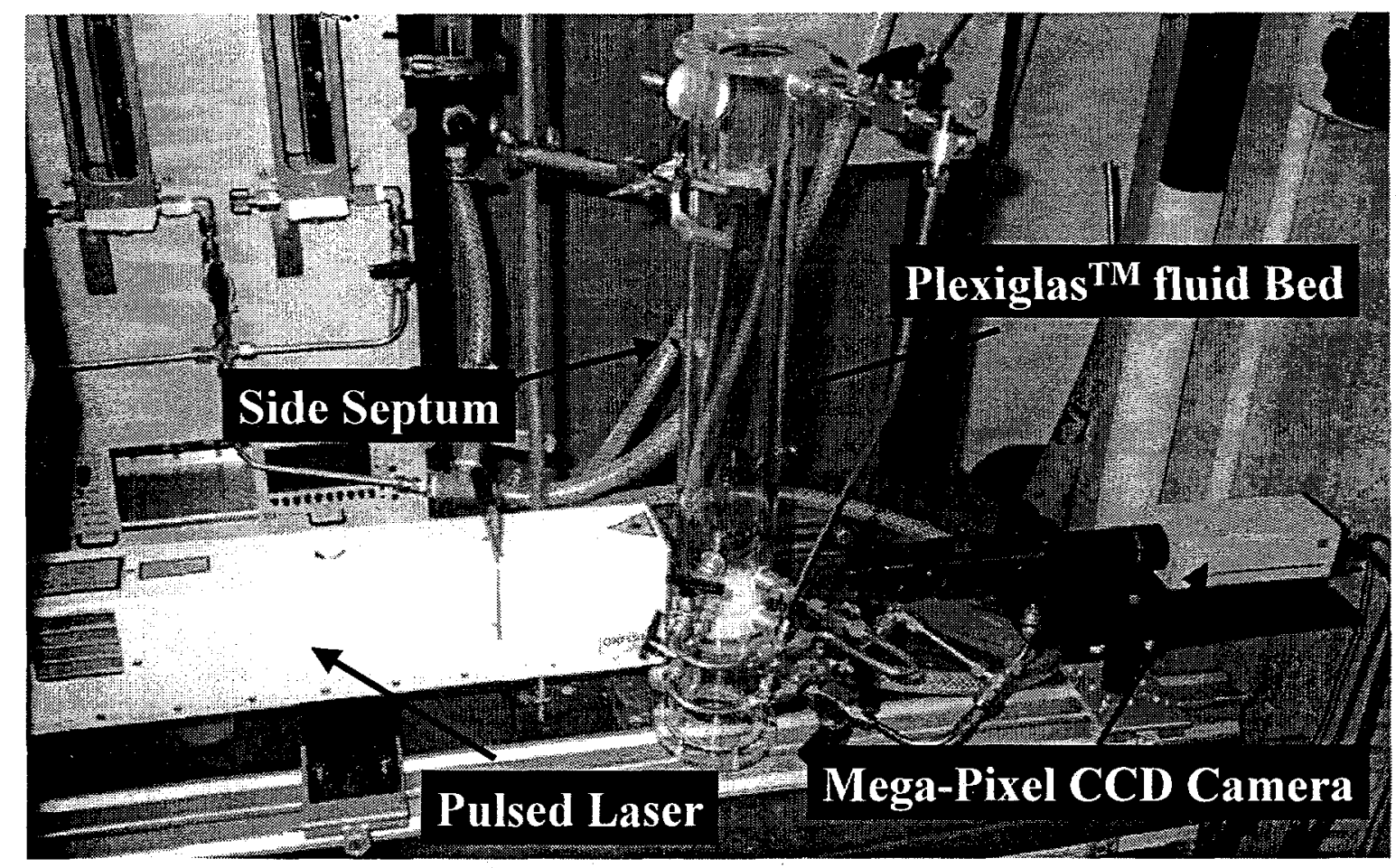

\section{Figure 8. Laser Imaging System Interfaced to Current Laboratory Fluidized Bed (Back Lighting)}

The bed is equipped with a side septum, allowing the accurate injection of silicone oil directly into the fluidized bed via a syringe. Gas flow will be controlled using mass flow controllers.

The bed is also equipped with a recently purchased state-of-the-art Oxford Lasers Company Visisizer ${ }^{\mathrm{TM}}$ MP complete pulsed laser imaging system (Model HSI1000 pulsed laser; Mega Pixels CCD, Software with Pentium III Computer; Oxford Lasers, Inc.; Acton, MA) for high-resolution imaging. It allows direct measurement of particle size and particle velocity within the upper surface of the bed (when set up for front lighting as shown in Figure 7). It can also be set up horizontally 
along the side of the bed with back lit images (fluid bed wall) and allow the visualization of the side of the upper surface of the bed (Figure 8). Particle agglomerate formation can be monitored continuously with this system and important inertial parameters such as particle size (Figures 9 and 10) and velocity can be tracked in real time as a function of liquid loading. Individual particles are tracked via sequential digital snapshots.

The initial approach will be to systematically vary the liquid loading, $q$, so as to determine its effect on the functionality of $\psi$. For example, porous $400 \mu \mathrm{m}$ silica particles (with measured pore volume) will be fluidized with a $50 / 50 \mathrm{~N}_{2} / \mathrm{Ar}$ gas mixture at ambient temperature. The minimum fluidization velocity, $\mathrm{u}_{\mathrm{mf}}$, will be determined using standard pressure drop methods. This measurement of $u_{\mathrm{mf}}$ will be carried out for different loadings (i.e. q) of silicone oil (e.g. Dow Corning $200 \circledR$ polydimethylsiloxane silicone oil) added by injection. Liquid loading experiments can be carried out for $400 \mu \mathrm{m}$ silica particles of different surface areas and porosities in order to develop an expression for $\psi$. For a given set of experiments, $\psi$ is determined by evaluating the force balance equation (equation (8)) at the point of minimum fluidization.

Since the values of $\rho_{p}$ increase with increasing $q$ values according to the equations.o.

\section{Figure 9. Using the Pulsed Laser for Real Time Imaging of Fluidization Process (top view)}

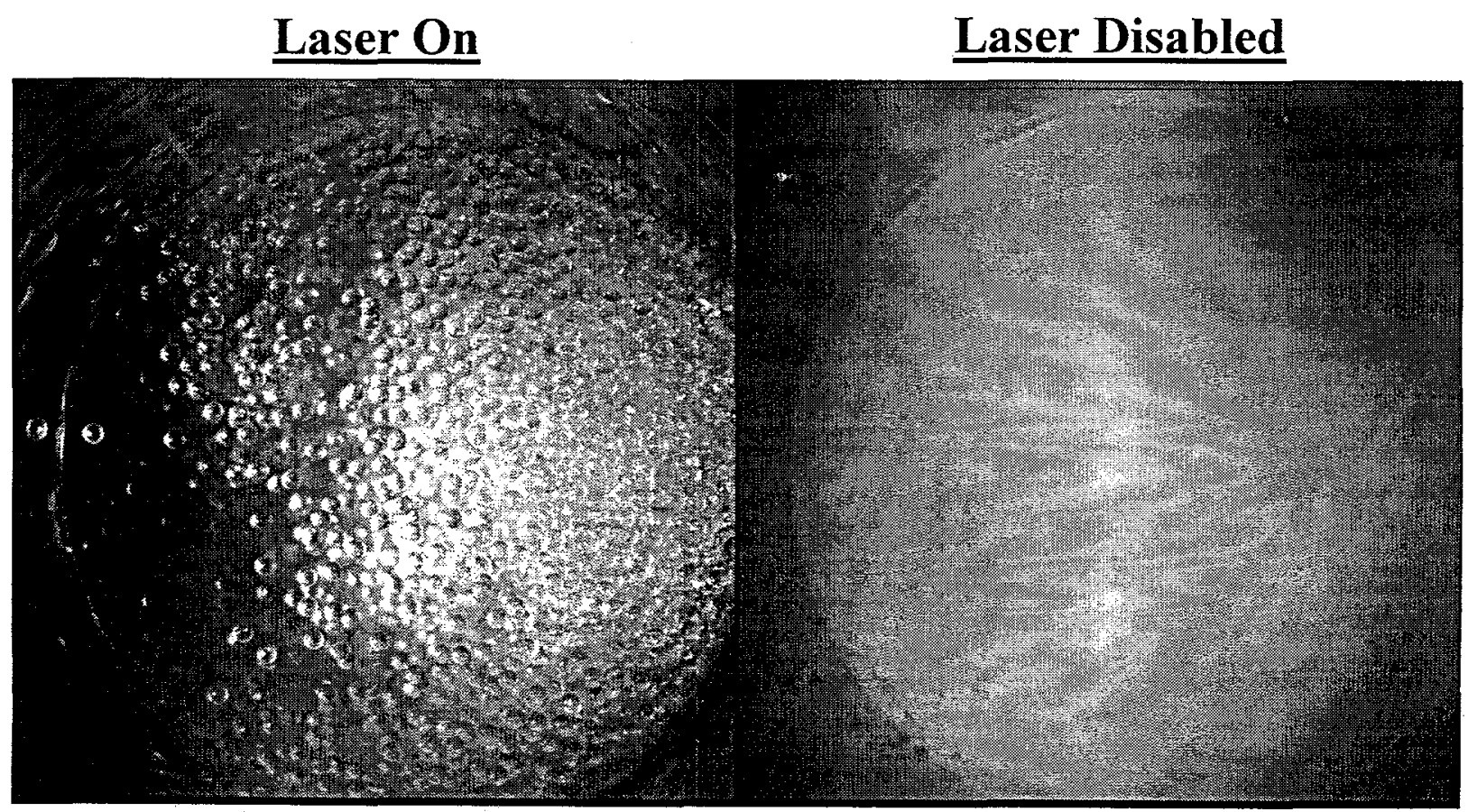

$\rho_{p}=\rho_{p}(@ q=0)+\varepsilon_{p} q \rho_{1}$ 
(assuming no coating of the particle with silicone oil changing the volume - can be verified with the laser system imaging) where $\rho_{1}$ is the density of the impregnating liquid, $u_{\mathrm{mf}}$ values would increase proportionally to $q$ in the absence of interparticle forces. However, Jutka et al. ${ }^{25}$ have shown that the

\section{Figure 10. Visisizer ${ }^{\mathrm{TM}}$ Output for Measured Particle Size Distribution (from laser real time software) Compared to Sieve}

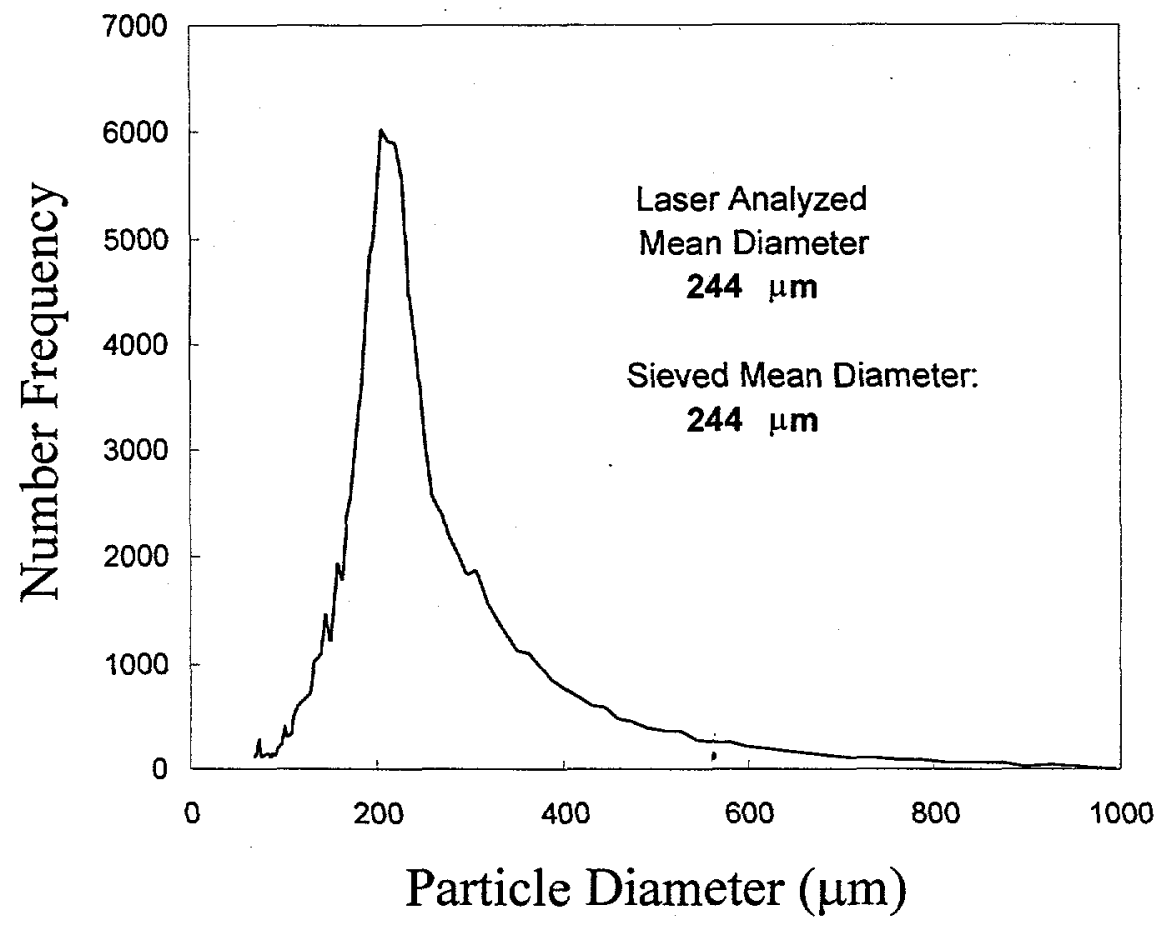

experimentally determined $u_{m f}$ values are higher than the predicted ones and that this difference increases with increased loading, q. As discussed throughout this report, the basis for these forces is the liquid bridges formed between contacting support particles, causing an interaction of the particles due to the Laplace pressure.

We can account for liquid capillary forces in calculating the minimum fluidization velocity, $\mathrm{u}_{\mathrm{mf}}$, by re-arranging equation (8):

$$
u_{\mathrm{mf}}=\left(\mu_{\mathrm{g}} /\left(\rho_{\mathrm{g}} \mathrm{d}_{\mathrm{p}}\right)\right)\left\{\left[\mathrm{C}_{1}^{2}+\mathrm{C}_{2}\left(\mathrm{~N}_{\mathrm{Ga}}+\mathrm{N}_{\mathrm{SLPC}}\right)\right]^{1 / 2}-\mathrm{C}_{1}\right\}
$$

where:

$$
\begin{aligned}
& \mathrm{C}_{1}=42.86\left(1-\varepsilon_{\mathrm{mf}}\right) / \phi_{\mathrm{s}} \\
& \mathrm{C}_{2}=\phi_{\mathrm{s}} \varepsilon_{\mathrm{mf}}{ }^{3} / 1.75 \\
& \mathrm{~N}_{\mathrm{SLPC}}=6 \sigma \mathrm{g}_{\mathrm{c}} \rho_{\mathrm{g}} \mathrm{d}_{\mathrm{p}} \psi / \mu_{\mathrm{g}}{ }^{2}
\end{aligned}
$$

From our theoretical development, the proposed dimensionless number, $\mathrm{N}_{\text {SLPC }}$, in equation (13) accounts for the additional energy alluded to by Jutka et al ${ }^{25}$ that is required to fluidize the support 
particles in the presence of a liquid loading, q. Without this term, equation (13) is identical to that developed by Wen and $\mathrm{Yu}^{38}$ where they proposed that typical values for $\mathrm{C}_{1}$ and $\mathrm{C}_{2}$ for fluidized bed systems are $\mathrm{C}_{1}=33.7$ and $\mathrm{C}_{2}=0.0408$.

It is critical for successful operation of the SLPC reactor process to understand the origin and effect of liquid capillary forces so that they can be measured and overcome in the process. Future work should be directed towards this understanding.

\section{Summary and Conclusions}

Thermodynamic calculations show that $\mathrm{Fe}_{2} \mathrm{O}_{3}$ particles are non-reactive in the presence of sodium salts and that supported $\mathrm{Na}_{2} \mathrm{CO}_{3}$ allows the capture of trace contaminants found in raw synthesis gas. Experimental and force balance modeling studies indicate that molten salts can be supported on fluidized porous support particles and that inertial forces need to dominate (large dense particles are most desirable). The future research includes experimental studies for a surrogate system to investigate the liquid capillary forces for molten $\mathrm{Na}_{2} \mathrm{CO}_{3}$ supported on $1 \mathrm{~mm}$ diameter fluidized $\mathrm{Fe}_{2} \mathrm{O}_{3}$ particles in a synthesis gas combustion environment. The novel molten carbonate SLPC process has potentially broad application for the simultaneous catalytic oxidation of synthesis gas with in-situ capture of trace contaminants ( $\mathrm{S}, \mathrm{Cl}$, etc.) (i.e. hot gas cleanup). 


\section{Nomenclature}

$\mathrm{C}_{1}:=42.86\left(1-\varepsilon_{\mathrm{mf}}\right) / \phi_{\mathrm{s}}$, used in equation (13)

$\mathrm{C}_{2}:=\phi_{\mathrm{s}} \cdot \varepsilon_{\mathrm{mf}}{ }^{3} / 1.75$, used in equation (13)

$\mathrm{d}_{\mathrm{p}}$ : = diameter of a sphere having the same volume as that of a particle $(\mathrm{m})$

$\mathrm{d}_{\mathrm{t}}$ : $\quad=$ tube diameter $(\mathrm{m})$

$\mathrm{F}_{\mathrm{c}}$ : $\quad=$ cohesive force $(\mathrm{N})$

$\mathrm{g}: \quad=$ gravitational acceleration $\left(=9.81 \mathrm{~m} / \mathrm{s}^{2}\right)$

$\mathrm{g}_{\mathrm{c}}: \quad=$ conversion factor $\left(=1 \mathrm{~kg} \cdot \mathrm{m} / \mathrm{N} \cdot \mathrm{s}^{2}\right)$

$\mathrm{L}_{\mathrm{f}}: \quad=$ expanded bed height $(\mathrm{m})$

$\mathrm{l}: \quad=$ distance up fluidized bed $(\mathrm{m})$

$\mathrm{N}_{\mathrm{Ca}}:=$ dimensionless Capillary Number $\left(=\mathrm{u}_{\mathrm{mf}} \cdot \mu_{\mathrm{g}} /\left(\sigma \cdot \mathrm{g}_{\mathrm{c}}\right)\right.$

$\mathrm{N}_{\mathrm{C} 0}:=$ dimensionless Cohesion Number $\left(=6 \cdot \mathrm{S} /\left(\left(\rho_{\mathrm{p}}-\rho_{\mathrm{g}}\right) \cdot \mathrm{d}_{\mathrm{p}} \cdot \mathrm{g}\right)\right)$

$N_{\mathrm{Ga}}:=$ dimensionless Galileo Number $\left(=\left(\rho_{\mathrm{g}} \cdot\left(\rho_{\mathrm{p}}-\rho_{\mathrm{g}}\right) \cdot \mathrm{d}_{\mathrm{p}}{ }^{3} \cdot \mathrm{g}\right) / \mu_{\mathrm{g}}{ }^{2}\right)$

$\mathrm{N}_{\mathrm{Re}}:=$ dimensionless Reynolds Number at minimum fluidization $\left(=\rho_{\mathrm{g}} \cdot \mathrm{u}_{\mathrm{mf}} \cdot \mathrm{d}_{\mathrm{p}} / \mu_{\mathrm{g}}\right)$

$\mathrm{N}_{\mathrm{SLPC}}:=$ derived dimensionless SLPC Number $\left(=6 \cdot \sigma \cdot \mathrm{g}_{\mathrm{c}} \cdot \rho_{\mathrm{g}} \cdot \mathrm{d}_{\mathrm{p}} \cdot \psi / \mu_{\mathrm{g}}{ }^{2}\right)$

q: $\quad=$ loading factor, fraction of pore volume filled with liquid

$\mathrm{S}: \quad=$ surface stress $\left(\mathrm{kg} / \mathrm{m} \cdot \mathrm{s}^{2}\right)$

SA: $\quad=$ surface area per mass of a support particle $\left(\mathrm{m}^{2} / \mathrm{g}\right)$

$\mathrm{T}: \quad=$ temperature $(\mathrm{K})$

$\mathrm{u}_{0}: \quad=$ superficial gas velocity $(\mathrm{m} / \mathrm{s})$

$\mathrm{u}_{\mathrm{mf}}: \quad=$ minimum fluidization velocity $(\mathrm{m} / \mathrm{s})$

$\mathrm{V}: \quad=$ volume $\left(\mathrm{m}^{3}\right)$

$\mathrm{W}_{\mathrm{B}}: \quad=$ total mass of fluidized bed support material $(\mathrm{kg})$

$\mathrm{W}_{1}:=$ total mass of liquid loaded on fluidized bed support material $(\mathrm{kg})$

\section{Greek Letter}

$\psi: \quad=$ proposed dimensionless liquid capillary force term for SLPC

$\varepsilon_{\mathrm{mf}}: \quad=$ fluidized bed voidage at minimum fluidization

$\varepsilon_{\mathrm{p}}: \quad=$ particle porosity (voidage within a support particle)

$\phi: \quad=$ angle defining the size of the liquid bridge for contacting wetted spheres

$\phi_{s}: \quad=$ sphericity of a particle

$\mu_{\mathrm{g}}: \quad=$ gas viscosity $(\mathrm{kg} / \mathrm{m} \cdot \mathrm{s})$

$\rho_{\mathrm{g}}: \quad=$ gas density $\left(\mathrm{kg} / \mathrm{m}^{3}\right)$

$\rho_{\mathrm{l}}: \quad=$ liquid density $\left(\mathrm{kg} / \mathrm{m}^{3}\right)$

$\rho_{\mathrm{p}}: \quad=$ particle density $\left(\mathrm{kg} / \mathrm{m}^{3}\right)$

$\sigma: \quad=$ surface tension $(\mathrm{N} / \mathrm{m})$

$\Delta \mathrm{P}: \quad=$ pressure drop across fluidized bed $\left(\mathrm{N} / \mathrm{m}^{2}\right)$ 


\section{VII: References}

[1] Edwards, B.H., J.N. Paullin, and K. Coghlan-Jordan, "Emerging Technologies for the Control of Hazardous Wastes," J. Hazard Mat., 12, 201 (1985).

[2] Freeman, H.M., "Innovative Thermal Processes for the Destruction of Hazardous Wastes," AIChE Symp. Ser., 81 (243), 139 (1985).

[3] Freeman, H.M., D.A. Olexsey, D.A. Oberacker, and R.E. Mournighan, "Thermal Destruction of Hazardous Waste - A State of the Art Review," J. Hazard. Mat., 14, 103 (1987).

[4] Oppelt, E.T., "Hazardous Waste Destruction," Environ. Sci. Technol., 20 (4), 312 (1986).

[5] Upadhye, R., "Molten Salt Takes the Bang Out of High Explosives," http://www.llnl.gov/str/Upadhye.html (2000).

[6] Greenberg, J., "Method of Catalytically Inducing Oxidation of Carbonaceous Materials by the Use of Molten Salts," U.S. Patent 3647358 (1972).

[7] Edwards, B., J. Paullin, and K. Coghlan-Jordan, "Emerging Technologies for the Destruction of Hazardous Wastes - Molten Salt Combustion," Pollution Technology Rev., $\underline{99}$, 146 (1983).

[8] Johanson, J., S. Yosim, L. Kellogg, and S. Sudar, "Elimination of Hazardous Wastes by the Molten Salt Oxidation Process," Proc. Annu. Res. Symp., 8 ${ }^{\text {th }}$. PN83-210450, 2344 (1983).

[9] Stelman, D., A. Stewart, S. Yosim, and R. Gay, "Treatment of Mixed Wastes by the Molten Salt Oxidation Process," Therm. Treat. Radioact. Hazard. Chem. Mixed. Med. Waste. Proc. Incineration. Conf. $11^{\text {th }}, 795$ (1992).

[10] Upadhye, R., C. Pruneda, and B. Watkins, "Molten Salt Destruction of Energetic Material Wastes as an Alternative to Open Burning, Environ. Sci. Res., 51, 267 (1996).

[11] Yosim, S. and K. Barclay, "Destruction of Hazardous Wastes by Molten Salt Combustion," Proc. Natl. Conf. Hazard. Waste Manage., 146 (1978).

[12] Meyer, C., U. Richers, and D. Hesse, "Distribution of Liquids in Porous Systems and its Relationship to the Stability of Supported Liquid Phase Catalysts, Hung. J. Ind. Chem., 22 (3), 191 (1994).

[13] Rony, P., "Diffusional Kinetics within Supported Liquid Phase Catalysts, J. Catalysis, 14, 142 (1969).

[14] Hoffmeister, M. and D. Hesse, "The Influence of the Pore Structure on the Operational Behavior of Supported Liquid Phase Catalysts," Chem. Eng. Sci., 45 (8), 2575 (1990). 
[15] Gottsleben, F., M. Hoffmeister, and D. Hesse, "Liquid Distribution in Porous Support Materials and Model Calculations on the Exchange Behavior of Supported Liquid Phase Catalysts," DECHEMA Monogram 122 (Katalyse), 269 (1991).

[16] Kolodziej, A.S. and J. Rogut, "A Study of the Internal Diffusion of Gases in Porous Catalysts in the Presence of a Liquid Phase," Chem. Eng. Process., 31 (4), 255 (1992).

[17] Wu, X., Y.A. Letuchy, and D.P. Eyman, "Catalytic Hydrodechlorination of $\mathrm{CCl}_{4}$ over SilicaSupported $\mathrm{PdCl}_{2}$-containing Molten Salt Catalysts: The Promotional Effects of $\mathrm{CoCl}_{2}$ and $\mathrm{CuCl}_{2}$, J. Catalysis, 161 (1), 164-177 (1996).

[18] Schmitz, A.D. D.P. Eyman, and K.B. Gloer, "Highly-active Methanol Dissociation Catalysts Derived from Supported Molten Salts," Energy Fuel, 8 (3), 729-740 (1994).

[19] Jelles, S.J., B.A.A.L. van Setten, M. Makkee, and J.A. Moulijn, "Supported Liquid PhaseCatalysts: A New Approach for Catalytic Oxidation in Diesel Exhaust Particulate Emission Control," Catalysis and Automotive Pollution Control IV, 116, 667-674 (1998).

[20] Ohlrogge, M., "Untersuchungen zum Wirbelschichteinsatz bei der Hydroformylierung von Propen mit Fluessigfilm-Traegerkatalysatoren," Ph.D. Dissertation, University of Hannover, Germany (1988).

[21] Brusewitz, R. and D. Hesse, "Use of Supported Liquid Phase Catalysts in Fluidized Bed Reactors," DECHEMA Monogram 122 (Katalyse), 283 (1991).

[22] Brusewitz, R. and D. Hesse, "Problems in Use of Supported Liquid-Phase Catalysts in Fluidized Bed Reactors," Chem. Eng. Technol., 15, 35-389 (1992).

[23] Hesse, D. and M.S. Redondon de Beloqui, "Effect of Pore Structure on the Operational Behavior of Supported Liquid Phase Catalysts," DECHEMA Monogram 118 (Katalyse), 305 (1989).

[24] Janus, H. and D. Hesse, "Use of Chromatography for Studying the Percolation Probability of Impregnated Support Systems," DECHEMA Monogram 118 (Katalyse), 287 (1989).

[25] Jutka, C., R. Bruesewitz, and D. Hesse, "Investigations on the use of Supported-Liquid-Phase Catalysts in Fluidized Bed Reactors," AIChE Symp. Ser., 88 (289), 122 (1992).

[26] Richers, U. and D. Hesse, "Stability of Supported Liquid Phase Catalysts," Chem. -Ing. Tech., 64 (7), 630 (1992). 
[27] Yin, Y., M. Te, F.-Y. Jiao, G.-G. Su, and R.-X. Gao, "Study of Supported Liquid Phase Catalysts for Hydroformylation of Olefins Contained in FCC Dry Gas," Proc. Int. Conf. Pet. Refin. Petrochem. Process., 2, 614, Int. Acad. Publ., Beijing (1991)

[28] Tardos, G., D. Mazone, and R. Pfeffer, "Destabilization of Fluidized Beds due to Agglomeration. Part 1. Theoretical Model," Canadian J. Chem. Eng., 63, 377 (1985).

[29] Lian, G.P., C. Thornton, and M.J. Adams, "Discrete Particle Simulation of Agglomerate Impact Coalescence," Chem. Eng. Sci., 53 (19), 3381-3391 (1998).

[30] Tardos, G. and R. Pfeffer, "Chemical Reaction Induced Agglomeration and Defluidization of Fluidized Beds,"'Powd. Technol., 85, 29-35 (1995).

[31] Jeffers, S., "Control Problem Waste Feeds in Fluid Beds," Chemical Engineering Progress, May, 59-63 (1999).

[32] Vuthalauru, H.B., T.M. Linjewile, D.-K. Zhang, and A.R. Manzoori, "Investigations into the Control of Agglomeration and Defluidization During Fluidized Bed Combustion of Low-rank Coals, Fuel, $\underline{78}, 419-425$ (1999).

[33] Thompson, W.T., A.D. Pelton, and C.S. Bale, "Facility for the Analysis of Chemical Thermodynamics [FACT]," Thermfact ltd., Mount-Royal, Quebec, Canada (1985).

[34] Mangold, E.C., and M.A. Muradaz, Coal Liquefaction and Gasification Technologies, Ann Arbor Science Publishers, Ann Arbor (1982).

[35] Hilbert, P.M., P.J. Czerpak, and A.W. Weimer, "Supported Liquid Phase Molten Salt Catalytic Fluidized Bed Reactor for Combined Hot Gas Cleanup/Low Temperature Combustion," paper presented at the 1999 Annual AIChE Meeting, Dallas, November (1999).

[36] Weimer, A.W., P.J. Czerpak, and P.M. Hilbert, "Supported Molten Salt Fluidized Bed Process," U.S. Provisional Patent Application, April (1999).

[37] Ergun, S., "Fluid Flow Through Packed Columns," Chem. Eng. Progr., 48, 89 (1952).

[38] Wen, C. and Y. Yu, "A Generalized Method for Predicting the Minimum Fluidization Velocity, AIChE Journal, 12, 610 (1966).

[39] Mikami, T., H. Kamiya, and M. Horioi, "The Mechanism of Defluidization of Iron Particles in a Fluidized Bed," Powder Technol., 89, 231 (1996).

[40] Seville, J., H. Silomon-Pflug, and P. Knight, "Modeling of Sintering in High Temperature Gas Fluidization," Powder Technol., 97, 160 (1998). 
[41] Formisani, B., R. Giromonte, and L. Mancuso, "Analysis of the Fluidization Process of

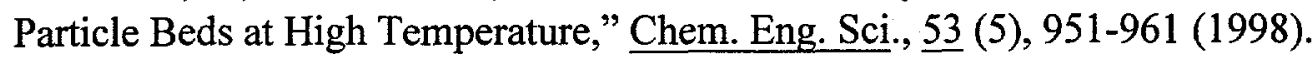

[42] Xie, H.Y., "the Role of Interparticle Forces in the Fluidization of Fine Powders," Powder Technol., 94 (2), 1099-1108 (1997).

[43] Ma, X.X. and K. Kato, "Effect of Interparticle Adhesion Forces on Elutriation of Fine Powders from a Fluidized Bed of a Binary Particle Mixture," Powder Technol., 95 (2), 93-101 (1998).

[44] Liss, B., T.R. Blake, A.M. Squires, and R. Bryson, "Incipient Defluidization of Sinterable Solids," in Fluidization ( $4^{\text {th }}$ International Conference held in Kashikojima, Japan), D. Kunii and R. Toei, Editors, United Engineering Trustees, New York, 249-256 (1984).

[45] Schubert, H., "Capillary Forces - Modeling and Application in Particulate Technology, "Powder Technol., 37, 107 (1984).

[46] Rietema, K., "Theoretical Derivation of Interparticle forces," in The Dynamics of Fine Powders, 65-93, Elsevier Science Publishers (New York), 1991.

[47] Hamaker, H., "The London Van der Waals Attraction Between Spherical Particles," Physica, 4, 1058 (1937).

[48] Lennard-Jones, J., "The Equation of State of Gases and Critical Phenomena," Physica, 4, 941 (1937).

[49] Seville, J.P.K. and R. Clift, "The Effect of Thin Liquid Layers on Fluidization Characteristics," Powder Technol., 37, 117-129 (1984).

[50] Yamazaki, R., N.-S. Han, Z.-F. Sun, and G. Jimbo, "Effect of Chemisorbed Water on Bed Voidage of High Temperature Fluidized Bed," Powder Technol., 84, 15-22 (1995).

[51] Massimilla, L. and G. Donsi, "Cohesive Forces Between Particles of Fluid-Bed Catalysts," Powder Technol., 15, 253-260 (1970).

[52] Clift, R., Particle-Particle Interactions in Gas-Particle Systems," in Powtech '85 Particle Technology, Inst. Chem. Engrs. Symp. Ser. No. 91, 27-44 (1985).

[53] Wright, P.C. and J.A. Raper, "Examination of Dispersed Liquid-Phase Three-Phase Fluidized Beds: Part 1. Non-porous, Uniform Particle Systems, Powder Technol., 97, 208-226 (1998).

[54] Wright, P.C. and J.A. Raper, "Role of Liquid Bridge Forces in Cohesive Fluidization," Trans. IChemE, 76 (A), 753-760 (1998). 
[55] Rhodes, M. J. and L.J. McLaughlin, "Predicting the Influence of Added Liquid on Gas Fluidized Bed Behavior," paper presented at the 1999 Annual AIChE Meeting, Dallas (November, 1999).

[56] Geldart, D. (editor), Gas Fluidization Technology, John Wiley \& Sons (1986). 


\section{Appendix A: Thermodynamic Modeling}

\section{A.1) FACT Introduction}

This section focuses on the results of thermodynamic equilibrium Gibbs Free Energy Minimization Calculations completed using the Facility for the Analysis of Chemical Thermodynamics (FACT) Equilib program module (Bale, Pelton et al. 1996). A variety of combustible gas streams were combined with an array of salts and support particles. The systems developed were tested under low/high temperature conditions and oxidizing/reducing conditions. The results of the FACT simulations were analyzed to determine which systems proved the most effective in capturing sulfur and mercury along with lowering $\mathrm{NO}_{\mathrm{x}}$ production.

For an overview detailing Gibbs Free Energy Minimization Calculations for ideal systems using the Newton-Raphson Solution of the Gibbs Free energy equations, see Smoot's Pulverized-Coal Combustion and Gasification (Smoot and Pratt 1979). The analysis is mathematically cumbersome, but is quite elegant in its ability to predict equilibrium compositions systems based on a fixed output temperature and pressure. The Equilib program module was run in both the ideal gas and ideal solution mode for all of the simulations.

\section{A.2) FACT Input Models}

Two different models were developed to determine the molar ratios of gaseous feed constituents in combination with an array of salts and supports. The first model used $\mathrm{CH}_{4}$ as the combustible reactant mixed with $10 \%$ excess air. The pre-mixed fuel/air was then used to fluidize a bed of fine ceramic particles with a designated salt loading. The model takes into account the effect of temperature, pressure, viscosity and varying voidage at minimum fluidization to obtain accurate molar ratios for input into the FACT Equilib program. This model showed that the $\varepsilon_{\mathrm{mf}}$ was a weak function of temperature and particle size with values typically being around 0.5 . Only a limited number of actual simulations were completed with this model; therefore, the details of the results are not included here. The results exhibited the same trends in terms of sulfur capture and relative reactivity of the support with the chosen salt seen using the second model..

The second model for which a majority of the equilibrium calculations were performed used the off-gas from different coal gasifiers as the combustible reactant. In this model, it was assumed: (1) that the bed voidage at minimum fluidization was 0.5 based on the results from the first model, (2) the salt loading was $10 \mathrm{wt} \%$, and (3) the support had no internal pore volume. These assumptions greatly simplified the necessary calculations to determine the molar ratios of the reactants to be inputted into FACT. Figure A.1 describes how the models were developed. 
Products: Equilibrium output from FACT at a specified temperature and pressure.

Examples $\mathrm{CO}_{2}, \mathrm{H}_{2} \mathrm{O}, \mathrm{NOx}, \mathrm{SO}_{2}, \mathrm{Hg}, \mathrm{N}_{2}$, salt related species.

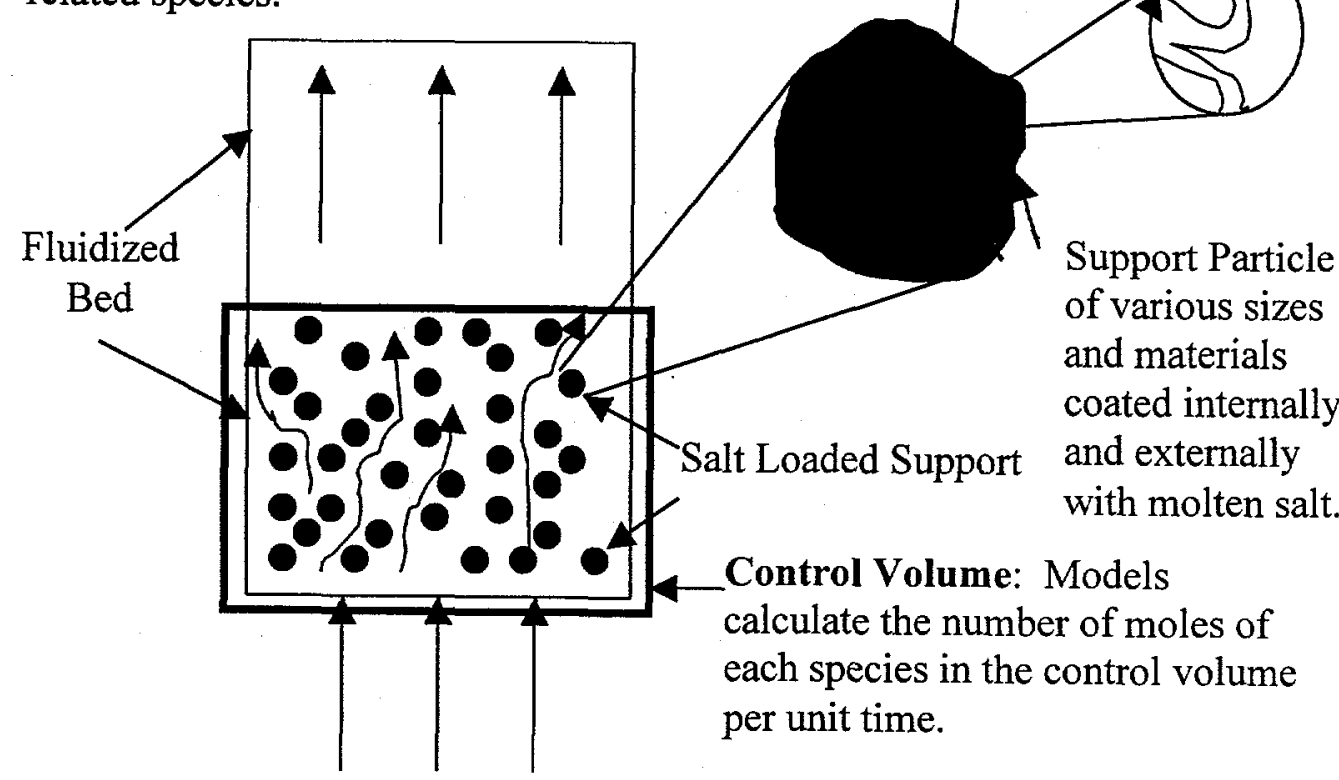

Gas Flow is either a premixed combustible methane/air mixture or the off-gas from a typical gasification process mixed with $10 \%$ excess air.

Figure A.1 FACT entering Molar Ratios Models Diagram. 
The four main purposes of these calculations centered on demonstrating that:

(1) The sulfur present in the off-gas from a typical gasification process is captured in the liquid/solid phase when combusted in the presence of various molten salt/support systems.

(2) The ability to run the combustion reaction at lower temperatures and maintain high combustion efficiencies due to the known oxidative catalytic effect of molten carbonates and nitrates. The result of lower temperature operation being the desirable reduction in the production of $\mathrm{NO}_{\mathrm{x}}$ compounds.

(3) Non-reactive salt/support systems. exist.

(4) The removal of trace amounts of mercury present in the off-gas from a coal gasifier is possible.

\section{A.3) Potential Supports}

The first desirable quality in a support is its chemical stability in the presence of various molten salts at elevated temperatures. Once this is established, cost is mostly likely the next most important characteristic. From the cost standpoint, silica and alumina are the most attractive, in light of their widespread availability in myriad particle size ranges and pore distributions. Unfortunately, as will be demonstrated, these two supports are not stable in the presence of the majority of molten salts investigated. A list of supports investigated is contained in Table A.1.

\section{A.4) Potential Salts}

In the case of the molten salts, the initial selection criteria were based on the salt's melting point and thermal stability. The carbonates were best suited for a temperature range just over $800^{\circ} \mathrm{C}\left(1472^{\circ} \mathrm{F}\right)$ due their melting point and their known oxidative catalytic effect. The nitrates were selected due to their catalytic potential at lower temperatures and lower melting points for low temperature capture in molten carbonate fuel cell systems. $\mathrm{Na}_{2} \mathrm{WO}_{4}$ was chosen due to its melting point being lower than $800^{\circ} \mathrm{C}$ and the potential for forming $\mathrm{Na}_{2} \mathrm{SO}_{4} . \mathrm{Na}_{2} \mathrm{SO}_{4}$ was chosen, as a baseline, assuming that it would not capture additional sulfur from the gas phase. Table A.2 contains the salt species chosen for experimentation along with some of their important properties.

The first step involved determining which salts/supports did not react with each other. It was assumed that, if the salt and support reacted with each other, the system would have been even more difficult to fluidize. From Tables A.1 and A.2, a matrix was created to determine which salt/support systems are stable over a specified temperature range. Table A.3 lists the molar ratios of salt per support based on one mole of support assuming a $10 \%$ weight loading of salt.

Equilib simulations were run from $1100-1500 \mathrm{~K}$ while varying the temperature by $50 \mathrm{~K}$ increments for the all salts with the exception of the nitrates which all dissociates by $1100 \mathrm{~K}$. The nitrate simulations were run from $500-1100 \mathrm{~K}$. FACT Equilib output was inspected to determine if a reaction occurred between the 
salt and support for each system. Table A.4 lists the potential supports in yellow as ' $a$ ' and ' $e$ '. Table A.4 clearly shows that both silica and alumina are reactive with all of the carbonates from $1100-1500 \mathrm{~K}$. They form various glassy compounds. 
Table A.1 List of Potential Supports and Important Properties.

\begin{tabular}{|c|c|c|}
\hline Support & $\begin{array}{c}\text { Molecular } \\
\text { Weight }\end{array}$ & $\begin{array}{c}\text { Density } \\
\left(\mathbf{g m} / \mathbf{c m}^{\mathbf{3}}\right.\end{array}$ \\
\hline $\mathrm{SiO}_{2}$ & 60.08 & 2.6 \\
\hline $\mathrm{Al}_{2} \mathrm{O}_{3}$ & 101.96 & 3.97 \\
\hline $\mathrm{ZrO}_{2}$ & 123.22 & 6.67 \\
\hline $\mathrm{NiO}$ & 74.69 & 5.89 \\
\hline $\mathrm{Fe}_{2} \mathrm{O}_{3}$ & 159.69 & 5.28 \\
\hline $\mathrm{WC}$ & 195.86 & 15.63 \\
\hline $\mathrm{TiO}_{2}$ & 79.88 & 3.84 \\
\hline $\mathrm{CaO}$ & 56.07 & 3.34 \\
\hline$(\mathrm{Ca})_{3}\left(\mathrm{PO}_{4}\right)_{2}$ & 310.07 & 3.14 \\
\hline
\end{tabular}

Table A.2 Selected Salt Species and Important Properties.

\begin{tabular}{|c|c|c|c|}
\hline Salt & Molecular Weight & Melting Point (C) & Density (gm/cm³) \\
\hline $\mathbf{N a}_{\mathbf{2}} \mathbf{C O}_{\mathbf{3}}$ & 105.89 & 858 & $1.9547 @ 900^{\circ} \mathrm{C}$ \\
\hline $\mathbf{K}_{\mathbf{2}} \mathbf{C O}_{\mathbf{3}}$ & 138.2 & 899 & $1.8747 @ 950^{\circ} \mathrm{C}$ \\
\hline $\mathbf{L i}_{\mathbf{2}} \mathbf{C O}_{\mathbf{3}}$ & 73.89 & 618 & $1.806 @ 800^{\circ} \mathrm{C}$ \\
\hline $\mathbf{N a}_{\mathbf{2}} \mathbf{W O}_{\mathbf{4}}$ & 293.82 & 698 & $3.79 @ 780^{\circ} \mathrm{C}$ \\
\hline $\mathbf{N a}_{2} \mathbf{S O}_{\mathbf{4}}$ & 142.04 & 884 & $2.04 @ 950^{\circ} \mathrm{C}$ \\
\hline $\mathbf{C s}_{\mathbf{2}} \mathbf{C O}_{\mathbf{3}}$ & 325.82 & 527 & Not Available \\
\hline $\mathbf{B}_{\mathbf{2}} \mathbf{O}_{\mathbf{3}}$ & 69.62 & 450 & $1.52 @ 1030^{\circ} \mathrm{C}$ \\
\hline $\mathbf{L i N O}$ & 68.95 & 252 & $1.7022 @ 400^{\circ} \mathrm{C}$ \\
\hline $\mathbf{N a N O}_{3}$ & 84.99 & 307 & $1.836 @ 400^{\circ} \mathrm{C}$ \\
\hline $\mathbf{K N O}_{\mathbf{3}}$ & 101.1 & 334 & $1.7537 @ 500^{\circ} \mathrm{C}$ \\
\hline $\mathbf{A g N O}_{\mathbf{3}}$ & 169.87 & 212 & $3.76754 @ 400^{\circ} \mathrm{C}$ \\
\hline
\end{tabular}




\section{A.5) Gasifier Outputs Mixed with 10\% Excess Air}

The next step in this section was to determine a baseline to compare the results for systems containing salt. To accomplish this, outputs from six typical gasifiers were chosen and mixed with $10 \%$ excess air and allowed to equilibrate over the desired temperature range without any salt present. Table A.5 lists the off-gas from various types of coal gasifiers. The gasifiers typically use different rank coal and varying steam/oxygen or steam/air feeds during the gasification process. Table A. 6 lists the mole fractions of gasifier species mixed with $10 \%$ excess air, which were then entered into the FACT Equilib program. The output from the FACT Equilib program represents the equilibrium products from a high temperature combustor used to combust various gasifier product gases with $10 \%$ excess air. 
Table A.3 Molar Ratios between Salts/Support Based on 1 mole of Support and 10 wt\% Loading.

\begin{tabular}{|c|c|c|c|c|c|c|c|c|c|}
\hline Matrix (i,j) & $\mathbf{S i O}_{\mathbf{2}}$ & $\mathbf{A l}_{\mathbf{2}} \mathbf{O}_{\mathbf{3}}$ & $\mathbf{Z r O}_{\mathbf{2}}$ & $\mathbf{N i O}$ & $\mathbf{F e}_{2} \mathbf{O}_{\mathbf{3}}$ & $\mathbf{W C}$ & $\mathbf{T i O}_{2}$ & $\mathbf{C a O}$ & $(\mathbf{C a})_{\mathbf{3}}(\mathbf{P O 4})_{\mathbf{2}}$ \\
\hline $\mathbf{N a}_{\mathbf{2}} \mathbf{C O}_{\mathbf{3}}$ & 0.06 & 0.11 & 0.13 & 0.08 & 0.17 & 0.21 & 0.08 & 0.06 & 0.33 \\
\hline $\mathbf{K}_{\mathbf{2}} \mathbf{C O}_{\mathbf{3}}$ & 0.05 & 0.08 & 0.10 & 0.06 & 0.13 & 0.16 & 0.06 & 0.05 & 0.25 \\
\hline $\mathbf{L i}_{\mathbf{2}} \mathbf{C O}_{\mathbf{3}}$ & 0.09 & 0.15 & 0.19 & 0.11 & 0.24 & 0.29 & 0.12 & 0.08 & 0.47 \\
\hline $\mathbf{N a}_{2} \mathbf{W O}_{\mathbf{4}}$ & 0.02 & 0.04 & 0.05 & 0.03 & 0.06 & 0.07 & 0.03 & 0.02 & 0.12 \\
\hline $\mathbf{N a}_{\mathbf{2}} \mathbf{S O}_{\mathbf{4}}$ & 0.05 & 0.08 & 0.10 & 0.06 & 0.12 & 0.15 & 0.06 & 0.04 & 0.24 \\
\hline $\mathbf{C s}_{\mathbf{2}} \mathbf{C O}_{\mathbf{3}}$ & 0.02 & 0.03 & 0.04 & 0.03 & 0.05 & 0.07 & 0.03 & 0.02 & 0.11 \\
\hline $\mathbf{B}_{\mathbf{2}} \mathbf{O}_{3}$ & 0.01 & 0.16 & 0.20 & 0.12 & 0.25 & 0.31 & 0.13 & 0.09 & 0.50 \\
\hline $\mathbf{L i N O 3}$ & 0.10 & 0.16 & 0.20 & 0.12 & 0.26 & 0.32 & 0.13 & 0.09 & 0.50 \\
\hline $\mathbf{N a N O 3}$ & 0.08 & 0.13 & 0.16 & 0.10 & 0.21 & 0.26 & 0.10 & 0.07 & 0.41 \\
\hline $\mathbf{K N O 3}$ & 0.07 & 0.11 & 0.14 & 0.08 & 0.18 & 0.22 & 0.09 & 0.06 & 0.34 \\
\hline $\mathbf{A g N O 3}$ & 0.04 & 0.07 & 0.08 & 0.05 & 0.10 & 0.13 & 0.05 & 0.04 & 0.20 \\
\hline
\end{tabular}

Table A.4 Reactivity of Various Salt/Support Systems.

\begin{tabular}{|c|c|c|c|c|c|c|c|c|c|}
\hline $\begin{array}{c}\text { Salt, } \\
\text { Support }\end{array}$ & $\mathrm{SiO}_{2}$ & $\mathrm{Al}_{2} \mathrm{O}_{3}$ & $\mathrm{ZrO}_{2}$ & $\mathrm{NiO}$ & $\mathrm{Fe}_{2} \mathrm{O}_{3}$ & WC & $\overline{\mathrm{TiO}_{2}}$ & $\mathrm{CaO}$ & $(\mathrm{Ca})_{3}\left(\mathrm{PO}_{4}\right)_{2}$ \\
\hline $\mathrm{Na}_{2} \mathrm{CO}_{3}$ & & & a & a & a & b. & & a & 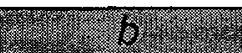 \\
\hline $\mathrm{K}_{2} \mathrm{CO}_{3}$ & & & a & $a$ & a & bat & & a & a \\
\hline $\mathrm{Li}_{2} \mathrm{CO}_{3}$ & & & & a & & & & a & a \\
\hline $\mathrm{Na}_{2} \mathrm{WO}_{4}$ & a & a & a & a & a & 6. & a & a & $a$ \\
\hline $\mathrm{Cs}_{2} \mathrm{CO}_{3}$ & a & a & & a & a & & a & a & $a$ \\
\hline $\mathrm{LiNO}_{3}$ & & & & e & e & & & $\bar{e}$ & $e$ \\
\hline $\mathrm{NaNO}_{3}$ & & & e & e & Bge & & & $e$ & 50 \\
\hline $\mathrm{KNO}_{3}$ & & & a & a & a & & 6 & a & a \\
\hline $\mathrm{AgNO}_{3}$ & & & & & & & & & \\
\hline
\end{tabular}

' $\mathbf{a}$ ' The salt and support are non-reactive over the entire temperature range tested.

' $b$ ' The salt and support are only non-reactive over a part of the temperature range tested.

' $c$ ' The salt and support are reactive over the entire temperature range tested.

'd' The salt is unstable over the entire range tested.

' $e$ ' The salt and support do not react over the entire temperature range, but the salt does dissociate at the higher temperatures of the range tested. 
Table A.5 Gasifier Outputs for 100 moles of Product.

\begin{tabular}{|c|c|c|c|c|c|c|}
\hline & $\begin{array}{c}\text { Lurgi } \\
\text { (Teggers } \\
\text { 1979) }\end{array}$ & $\begin{array}{c}\text { Winkler( } \\
\text { Teggers } \\
\text { 1979) }\end{array}$ & $\begin{array}{c}\text { Kopper- } \\
\text { Totzek } \\
\text { (Teggers } \\
\text { 1979) }\end{array}$ & $\begin{array}{c}\text { Texaco } \\
\text { (Mangold, } \\
\text { Muradaz et } \\
\text { al. 1982) }\end{array}$ & IGCC & $\begin{array}{c}\text { Shell- } \\
\text { Koppers } \\
\text { (Mangold, } \\
\text { Muradaz et } \\
\text { al. 1982) }\end{array}$ \\
\hline $\mathrm{Air} / \mathrm{O}_{2}$ Feed & $\overline{\mathrm{O}_{2}}$ & $\overline{\mathrm{O}_{2}}$ & $\mathrm{O}_{2}$ & Air & Air & $\mathrm{O}_{2}$ \\
\hline $\begin{array}{c}\text { Type of } \\
\text { Coal }\end{array}$ & UNK & Brown & UNK & $\begin{array}{c}\text { low- } \\
\text { bituminous }\end{array}$ & UNK & $\begin{array}{l}\text { W. German } \\
\text { Bituminous }\end{array}$ \\
\hline $\mathrm{CO}$ & 11.55 & 45.00 & 57.00 & 19.46 & 22.90 & 65.60 \\
\hline $\mathrm{CH}_{4}$ & 10.65 & 1.50 & 0.10 & 0.10 & 1.00 & 0.40 \\
\hline$\overline{\mathbf{H}_{2}}$ & 43.15 & 38.45 & 28.70 & 11.61 & 9.50 & 31.30 \\
\hline $\cos$ & 0.15 & 0.05 & 0.03 & 0.05 & 0.00 & 0.00 \\
\hline $\mathrm{H}_{2} \mathrm{~S}$ & 0.30 & 0.15 & 0.20 & 0.52 & 0.10 & 0.40 \\
\hline $\mathrm{NH}_{3}$ & 0.00 & 0.00 & 0.00 & $0.11 \ldots$ & 0.00 & 0.00 \\
\hline $\mathrm{CO}_{2}$ & 32.88 & 13.99 & 12.49 & 7.68 & 4.40 & 1.50 \\
\hline $\mathrm{C}_{2} \mathrm{H}_{6}$ & 0.90 & 0.00 & 0.00 & 0.00 & 0.00 & 0.00 \\
\hline $\mathbf{N}_{2}$ & 0.25 & 0.70 & 1.20 & 59.76 & 60.00 & 0.60 \\
\hline $\mathrm{O}_{2}$ & 0.00 & 0.00 & 0.00 & 0.00 & 0.00 & 0.00 \\
\hline $\mathbf{A r}$ & 0.15 & 0.10 & 0.20 & 0.68 & 2.07 & 0.20 \\
\hline $\mathbf{H g}^{*}$ & $1.06 \mathrm{E}-6$ & $4.12 \mathrm{E}-6$ & $5.22 \mathrm{E}-6$ & $1.78 \mathrm{E}-6$ & $2.10 \mathrm{E}-6$ & $6.00 \mathrm{E}-6$ \\
\hline $\mathrm{HCl}^{*}$ & 0.02 & 0.06 & 0.08 & 0.03 & 0.03 & 0.09 \\
\hline Total Moles & 100 & 100 & 100 & 100 & 100 & 100 \\
\hline
\end{tabular}

${ }^{*} \mathrm{Hg}$ and $\mathrm{HCl}$ were not included in referenced gasifier outputs.

Table A.6 Species Mole Fraction with 10\% Excess Air and Gasifier Output for Various Gasifiers.

\begin{tabular}{|c|c|c|c|c|c|c|}
\hline & Lurgi & Winkler & $\begin{array}{c}\text { Koppers- } \\
\text { Totzek }\end{array}$ & Texaco & IGCC & $\begin{array}{c}\text { Shell- } \\
\text { Koppers }\end{array}$ \\
\hline $\mathbf{C O}$ & $3.24 \mathrm{E}-2$ & $1.34 \mathrm{E}-1$ & $1.75 \mathrm{E}-1$ & $1.06 \mathrm{E}-1$ & $1.17 \mathrm{E}-1$ & $1.83 \mathrm{E}-1$ \\
\hline $\mathbf{C H}_{\mathbf{4}}$ & $2.99 \mathrm{E}-2$ & $4.48 \mathrm{E}-3$ & $3.07 \mathrm{E}-4$ & $5.47 \mathrm{E}-4$ & $5.12 \mathrm{E}-3$ & $1.12 \mathrm{E}-3$ \\
\hline $\mathbf{H}_{\mathbf{2}}$ & $1.212 \mathrm{E}-1$ & $1.15 \mathrm{E}-1$ & $8.81 \mathrm{E}-2$ & $6.35 \mathrm{E}-2$ & $4.86 \mathrm{E}-2$ & $8.74 \mathrm{E}-2$ \\
\hline $\mathbf{C O S}$ & $4.213 \mathrm{E}-4$ & $1.49 \mathrm{E}-4$ & $9.21 \mathrm{E}-5$ & $2.74 \mathrm{E}-4$ & 0.00 & 0.00 \\
\hline $\mathbf{H}_{\mathbf{2}} \mathbf{S}$ & $8.427 \mathrm{E}-4$ & $4.48 \mathrm{E}-4$ & $6.14 \mathrm{E}-4$ & $2.84 \mathrm{E}-3$ & $5.12 \mathrm{E}-4$ & $1.12 \mathrm{E}-3$ \\
\hline $\mathbf{N H}_{\mathbf{3}}$ & 0.00 & 0.00 & 0.00 & $6.02 \mathrm{E}-4$ & 0.00 & 0.00 \\
\hline $\mathbf{C O}_{\mathbf{2}}$ & $9.236 \mathrm{E}-2$ & $4.18 \mathrm{E}-2$ & $3.83 \mathrm{E}-2$ & $4.20 \mathrm{E}-2$ & $2.25 \mathrm{E}-2$ & $4.19 \mathrm{E}-3$ \\
\hline $\mathbf{C}_{\mathbf{2}} \mathbf{H}_{\mathbf{6}}$ & $2.53 \mathrm{E}-3$ & 0.00 & 0.00 & 0.00 & 0.00 & 0.00 \\
\hline $\mathbf{N}_{\mathbf{2}}$ & $5.69 \mathrm{E}-1$ & $2.09 \mathrm{E}-3$ & $5.51 \mathrm{E}-1$ & $6.85 \mathrm{E}-1$ & $6.93 \mathrm{E}-1$ & $5.71 \mathrm{E}-1$ \\
\hline $\mathbf{O}_{\mathbf{2}}$ & $1.51 \mathrm{E}-1$ & 0.00 & $1.46 \mathrm{E}-1$ & $9.51 \mathrm{E}-2$ & $1.02 \mathrm{E}-1$ & $1.51 \mathrm{E}-1$ \\
\hline $\mathbf{A r}^{*}$ & $4.213 \mathrm{E}-4$ & $2.99 \mathrm{E}-4$ & $6.14 \mathrm{E}-4$ & $3.72 \mathrm{E}-3$ & $1.06 \mathrm{E}-2$ & $3.07 \mathrm{E}-4$ \\
\hline $\mathbf{H g}^{*}$ & $2.97 \mathrm{E}-9$ & $1.23 \mathrm{E}-8$ & $1.60 \mathrm{E}-8$ & $9.74 \mathrm{E}-9$ & $1.07 \mathrm{E}-8$ & $1.68 \mathrm{E}-8$ \\
\hline $\mathbf{H C l}{ }^{*}$ & $4.45 \mathrm{E}-5$ & $1.85 \mathrm{E}-4$ & $2.40 \mathrm{E}-4$ & $1.46 \mathrm{E}-4$ & $1.61 \mathrm{E}-4$ & $2.52 \mathrm{E}-4$ \\
\hline $\mathbf{T o t a l}$ & 1 & 1 & 1 & 1 & 1 & 1 \\
$\mathbf{M o l e s}$ & & & & & & \\
\hline
\end{tabular}

Significant gaseous species were selected from the Equilib equilibrium outputs and entered into a spreadsheet. The type of gasifier did not have a significant 
affect on the systems' equilibrium mole fractions for various gaseous species. In light of this fact, the Koppers-Totzek gasifier output was chosen to represent all of gasifiers outputs. Figure A.1 contains the equilibrium speciation for the KoppersTotzek gasifier. The carbon monoxide and hydrogen mole fractions are significantly lower due to the oxidation process. The hydrogen mole fraction was less than 1E-10, which is the reason it is not included in Figure A.2. There are high concentrations of $\mathrm{CO}_{2}$ and $\mathrm{H}_{2} \mathrm{O}$, which is expected after oxidizing the hydrogen and carbon monoxide. The primary species of concern: $\mathrm{NO}_{\mathrm{x}}, \mathrm{SO}_{\mathrm{x}}$ and $\mathrm{Hg}$ are all present. As expected, $\mathrm{NO}_{\mathrm{x}}$ production increases with temperature from about $20 \mathrm{ppm}-\mathrm{v}$ at $1100 \mathrm{~K}$ up to 300 ppm-v at $1500 \mathrm{~K}$. The $\mathrm{SO}_{2}$ concentration is a weak function of temperature with only a slight concentration increase as the temperature goes up. Its typical concentration in the Koppers-Totzek system is around 800.ppm. Figure A.3 shows $\mathrm{SO}_{2}$ mole fractions for all of the gasifiers. The differences in the amount of $\mathrm{SO}_{2}$ are proportional to the amount of sulfur present in the original gas stream. The Texaco Gasifier equilibrium concentration of $\mathrm{SO}_{2}$ is the highest, but it also has the highest concentration of $\mathrm{H}_{2} \mathrm{~S}$ and $\mathrm{COS}$ in its FACT input listed in Table A.5. If the $\mathrm{SO}_{2}$ mole fractions for the respective gasifiers are normalized by the amount of sulfur entering the system, the result seen in Figure A.4 shows that all normalized concentrations are all essentially one. 
Significant Gaseous Species Mole Fraction vs Temperäture for a Koppers-Totzek Gasifier Off-Gas with no Salt/Support Present

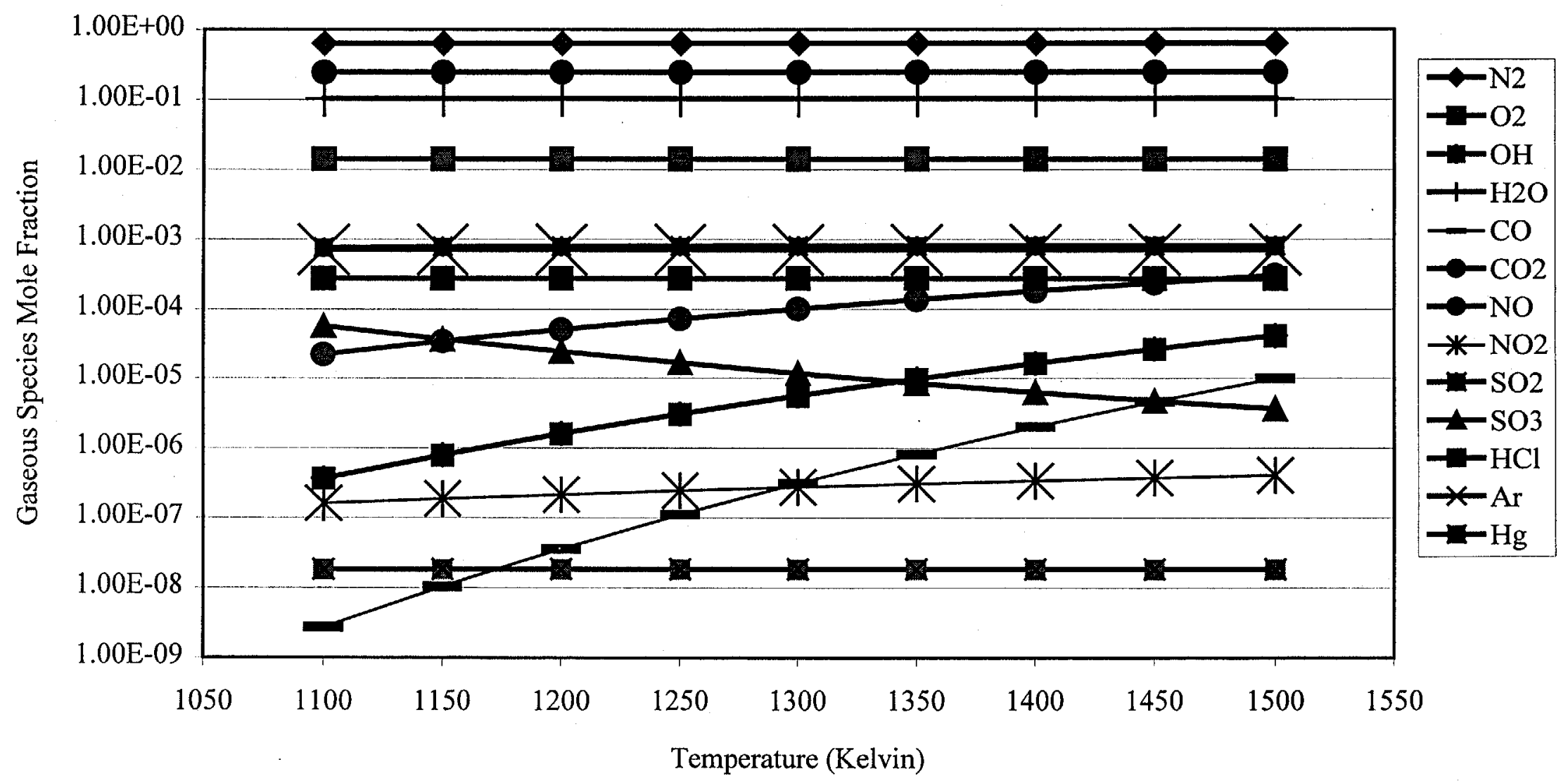

Figure A.2 Significant Gaseous Species for a Koppers-Totzek Off-Gas with no Salt/Support mixed with $10 \%$ Excess Air. 
$\mathrm{SO}_{2}$ Mole Fraction vs Temperature for Six Different Gasifier Outputs with no Salt/Support Present

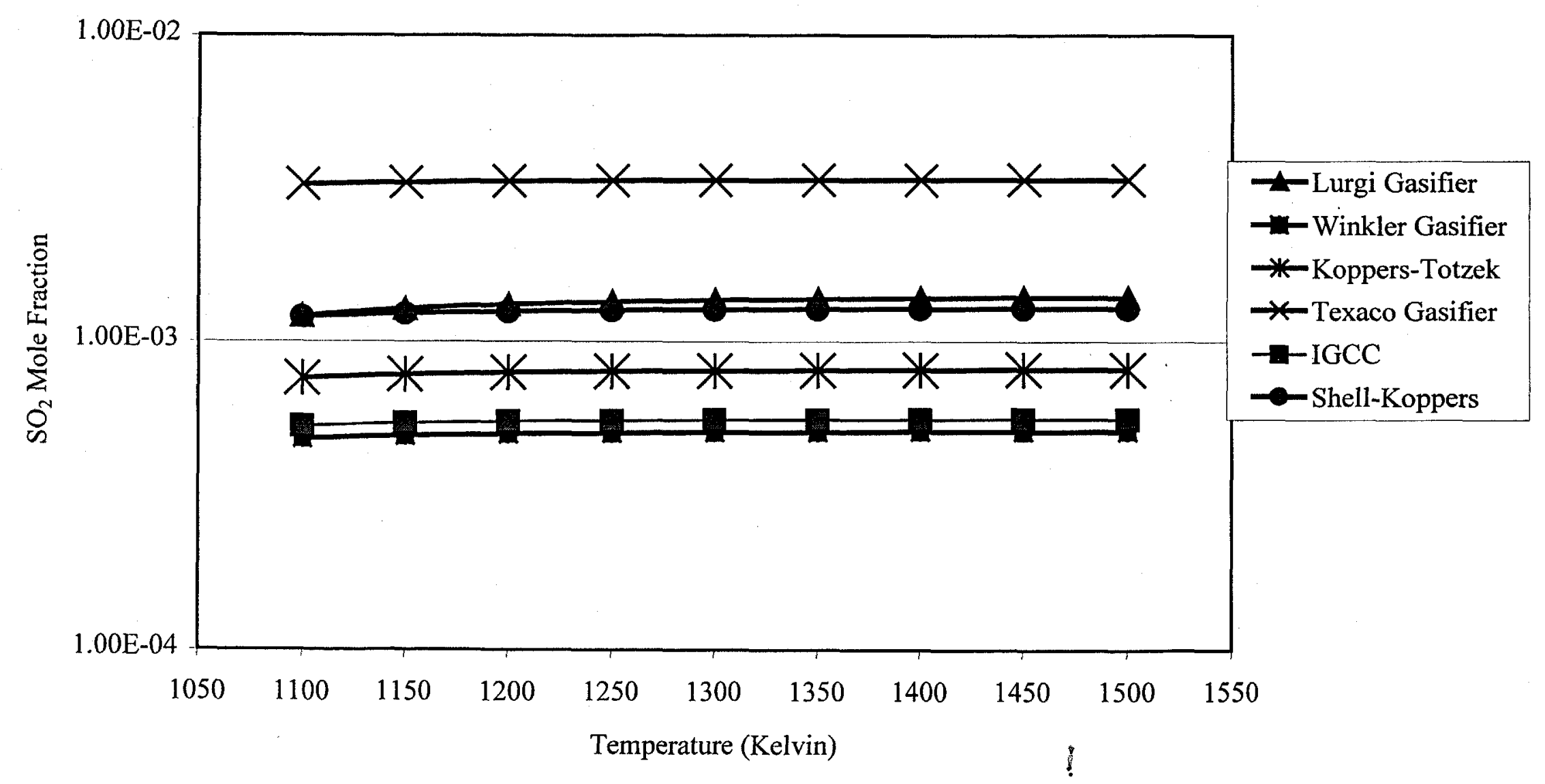

Figure A.3 $\mathrm{SO}_{2}$ Mole Fraction for Six Different Gasifiers with no Salt/Support Present mixed with $10 \%$ Excess Air. 
Normalized $\mathrm{SO}_{2}$ Mole Fraction vs Temperature for Six Different Gasifier Outputs with no Salt/Support Present

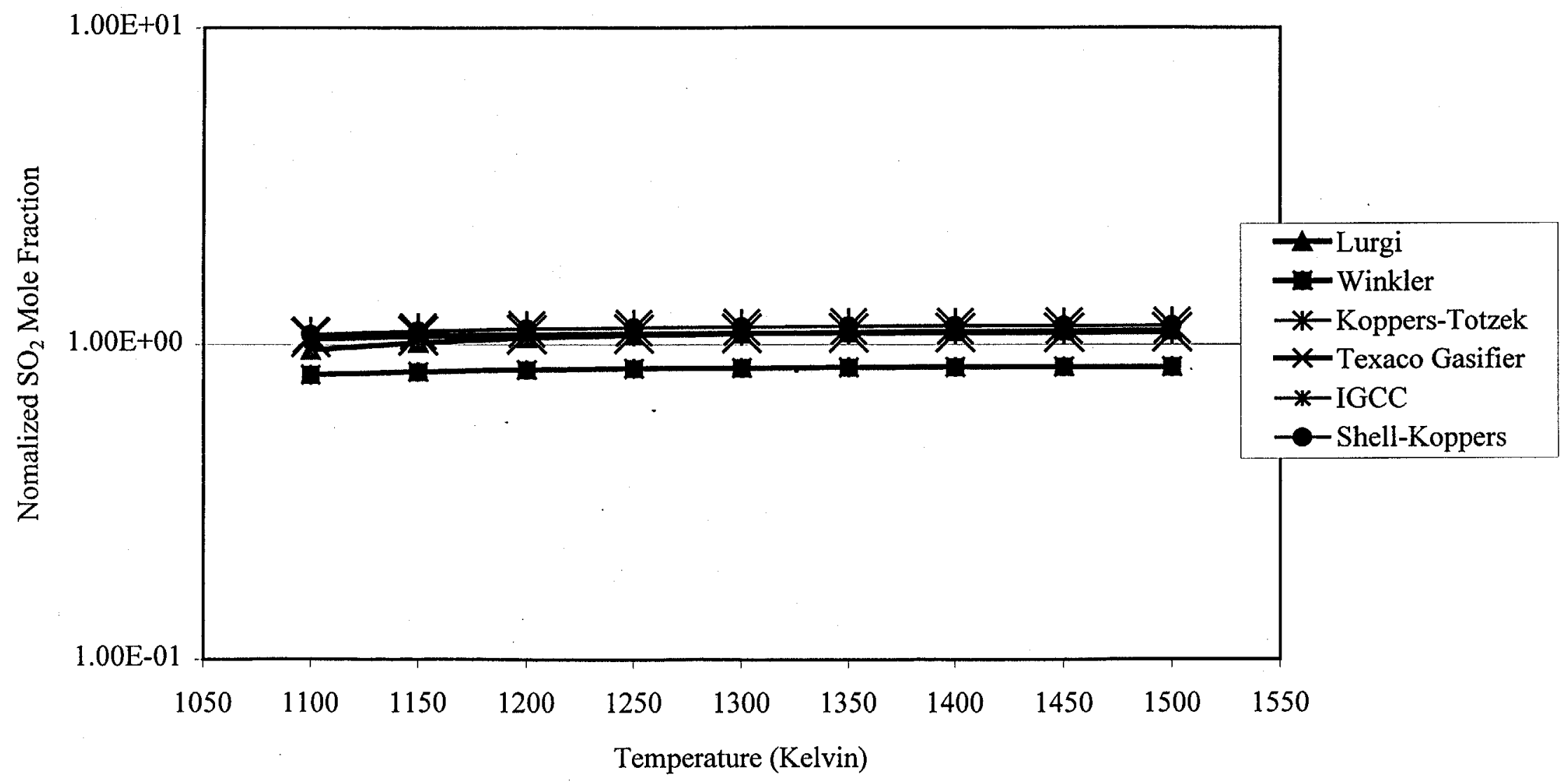

Figure A.4 Normalized $\mathrm{SO}_{2}$ Mole Fraction for Six Different Gasifiers with no Salt/Support Present mixed with $10 \%$ Excess Air. 


\section{A.6) Salt/Support/Gasifier Equilibrium Simulations}

There were four primary regions investigated as dictated by in Figure A.5. High temperature simulations were completed using the carbonates along with $\mathrm{Na}_{2} \mathrm{WO}_{4}, \mathrm{Na}_{2} \mathrm{SO}_{4}$, and $\mathrm{B}_{2} \mathrm{O}_{3}$ in conjunction with the supports found in Table A.1. Each simulation was assigned a three number designator in the form of (i.j.k). ' $i$ ', ' $j$ ', and ' $k$ ' represent the number of the salt, support, and gasifier off-gas used respectively. For example, experiment (1.3.3) signifies a system with $\mathrm{Na}_{2} \mathrm{CO}_{3}, \mathrm{ZrO}_{2}$, and the Koppers-Totzek Off-Gas. Oxidizing condition simulations were completed to test the applicability of these systems as a hot gas clean up strategy where the combustion and clean up processes physically occur within the same fluidized bed reactor. The reducing condition simulations were analyzed to ascertain the feasibility of SLPC with molten salts as a hot gas clean up strategy for molten carbonate fuel cells. 


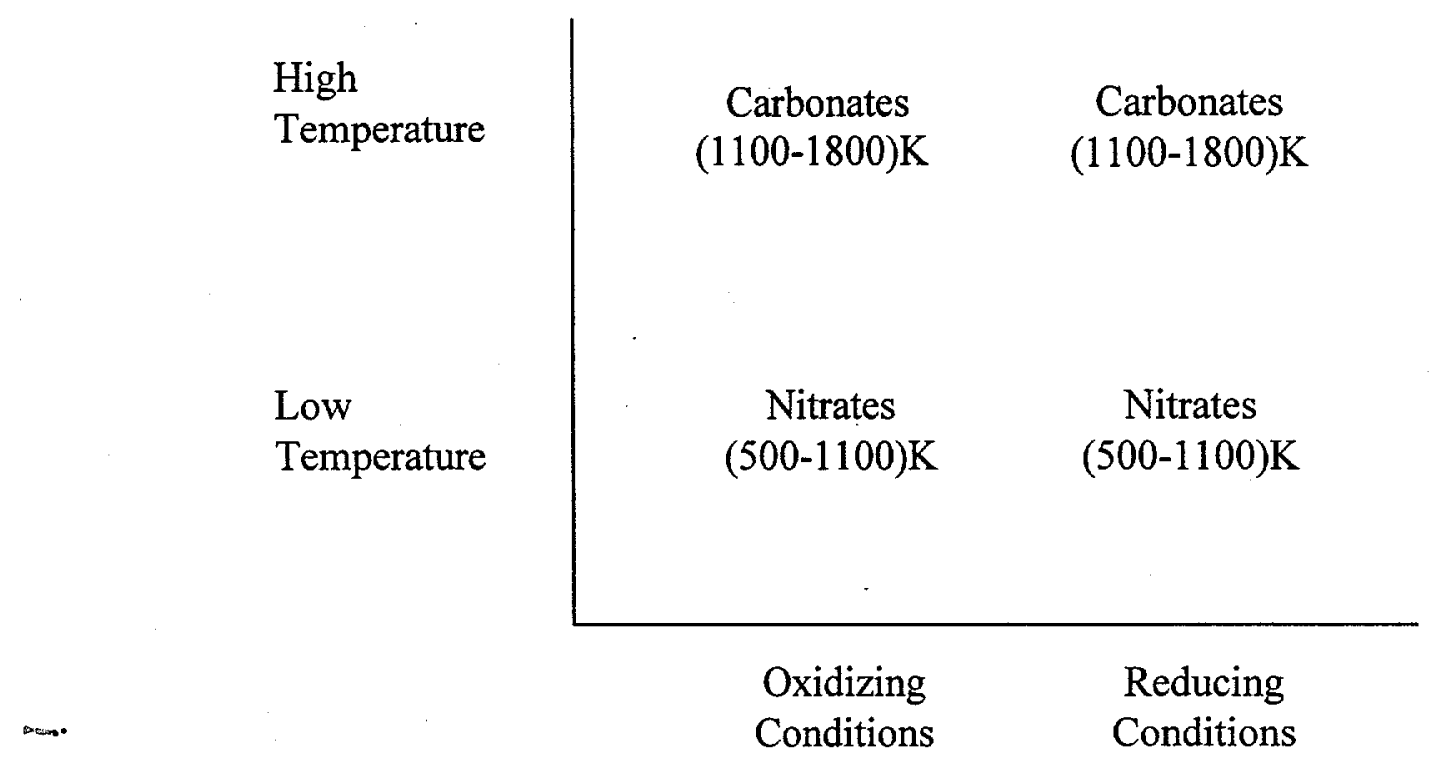

Figure A.5 Experimental Design Matrix for FACT Simulations. 


\section{A.6a) High Temperature/Oxidizing Conditions Simulations}

The initial purpose for exploring the equilibrium speciation with FACT was to investigate systems at high temperature under oxidizing conditions to demonstrate insitu capture of sulfur in the form of a molten sulfate and reduced $\mathrm{NO}_{\mathrm{x}}$ formation compared to current fossil fuel power generation processes. Looking back to Table A.4, there are a large number of possible salt, support, and gasifier combinations that warrant examination. Even after eliminating the systems where the salt and the support react, there are still too many simulations to run. Having seen that the gasifier input does not dramatically affect the equilibrium speciation, simulations were only run for one type of gasifier in each region investigated.

The first step for the high temperature region under oxidizing conditions involved picking a gasifier, in this case the Koppers-Totzek $(k=3)$ was chosen. Next, simulations were run from $1100-1800 \mathrm{~K}$ for each salt with a corresponding nonreactive support. The FACT molar ratio inputs are listed in Table A.7. As long as the support is non-reactive with the salt and gaseous constituents in the system, its presence should not affect the equilibrium speciation. In most cases $\mathrm{ZrO}_{2}$ satisfied this criterion except for the cases where lithium or cesium was present in the system. In these cases, $\mathrm{NiO}$ was substituted as the non-reactive support. Figure A.6 shows the $\mathrm{SO}_{2}$ mole fraction for the high temperature salts. The nitrates were not included in this section due their lack of thermal stability in the temperature region investigated.

After inspecting Figure A.6, a number of observations can be made. First, the supported salts, $\mathrm{Na}_{2} \mathrm{WO}_{4}$ and $\mathrm{B}_{2} \mathrm{O}_{3}$, do not capture any sulfur. No liquid or solid sulfur species form during $\mathrm{Na}_{2} \mathrm{WO}_{4}$ 's and $\mathrm{B}_{2} \mathrm{O}_{3}$ 's respective simulations and their individual $\mathrm{SO}_{2}$ concentrations are very similar to that of $\mathrm{Na}_{2} \mathrm{SO}_{4}$. The $\mathrm{Na}_{2} \mathrm{SO}_{4}$ 's $\mathrm{SO}_{2}$ concentration does start to increase relative to $\mathrm{Na}_{2} \mathrm{WO}_{4}$ 's and $\mathrm{B}_{2} \mathrm{O}_{3}$ 's at $1600 \mathrm{~K}$ due to the gradual thermal decomposition of $\mathrm{Na}_{2} \mathrm{SO}_{4}$.

The second finding, which is more exciting than the first, is that all of the carbonates do in fact capture sulfur in the solid/liquid phase as a sulfate, thus, reducing the amount of $\mathrm{SO}_{2}$ in the gas phase. It appears that $\mathrm{Cs}_{2} \mathrm{CO}_{3}$ is the most effective for capturing sulfur, until a mistake in the FACT thermodynamic database was discovered. The thermodynamic database has $\mathrm{Cs}_{2} \mathrm{CO}_{3}(\mathrm{~s})$ as the stable species above $800 \mathrm{~K}$. Below $800 \mathrm{~K} \mathrm{Cs}_{2} \mathrm{CO}_{3}$ (liquid) is the stable species. With this in mind, $\mathrm{Cs}_{2} \mathrm{CO}_{3}$ would undergo a phase transition at $800 \mathrm{~K}$, but in the direction of decreasing entropy as temperature increases. With results for $\mathrm{Cs}_{2} \mathrm{CO}_{3}$ suspect, $\mathrm{K}_{2} \mathrm{CO}_{3}$ is the best candidate from the perspective of $\mathrm{SO}_{2}$ reduction. The carbonates as a group consistently do a better job capturing sulfur at the lower portion of the temperature range.

Another concern with using the molten salts at elevated temperatures is the amount of salt related gaseous species that form. Figures A.7-A.10 all plot the significant salt related gaseous species for the individual molten carbonate systems. From the four graphs, it appears that $\mathrm{Na}_{2} \mathrm{CO}_{3}, \mathrm{~K}_{2} \mathrm{CO}_{3}$, and $\mathrm{Li}_{2} \mathrm{CO}_{3}$ have approximately the same gaseous species concentrations as a function of temperature. At temperatures greater than $1400 \mathrm{~K}$ the formation of the gaseous salt hydroxide becomes significant reaching concentrations of $10000 \mathrm{ppm}$. From these figures it is obvious that running the process at the lowest temperature that is kinetically feasible 
will facilitate reducing the dissociation of the molten salt and reduce the amount of sulfur leaving the system in the form of a gaseous sulfate. 
Table A.7 FACT entering Molar Ratios for High Temperature Salts, a KoppersTotzek Off-Gas, and a Non-Reactive Support under Oxidizing Conditions.

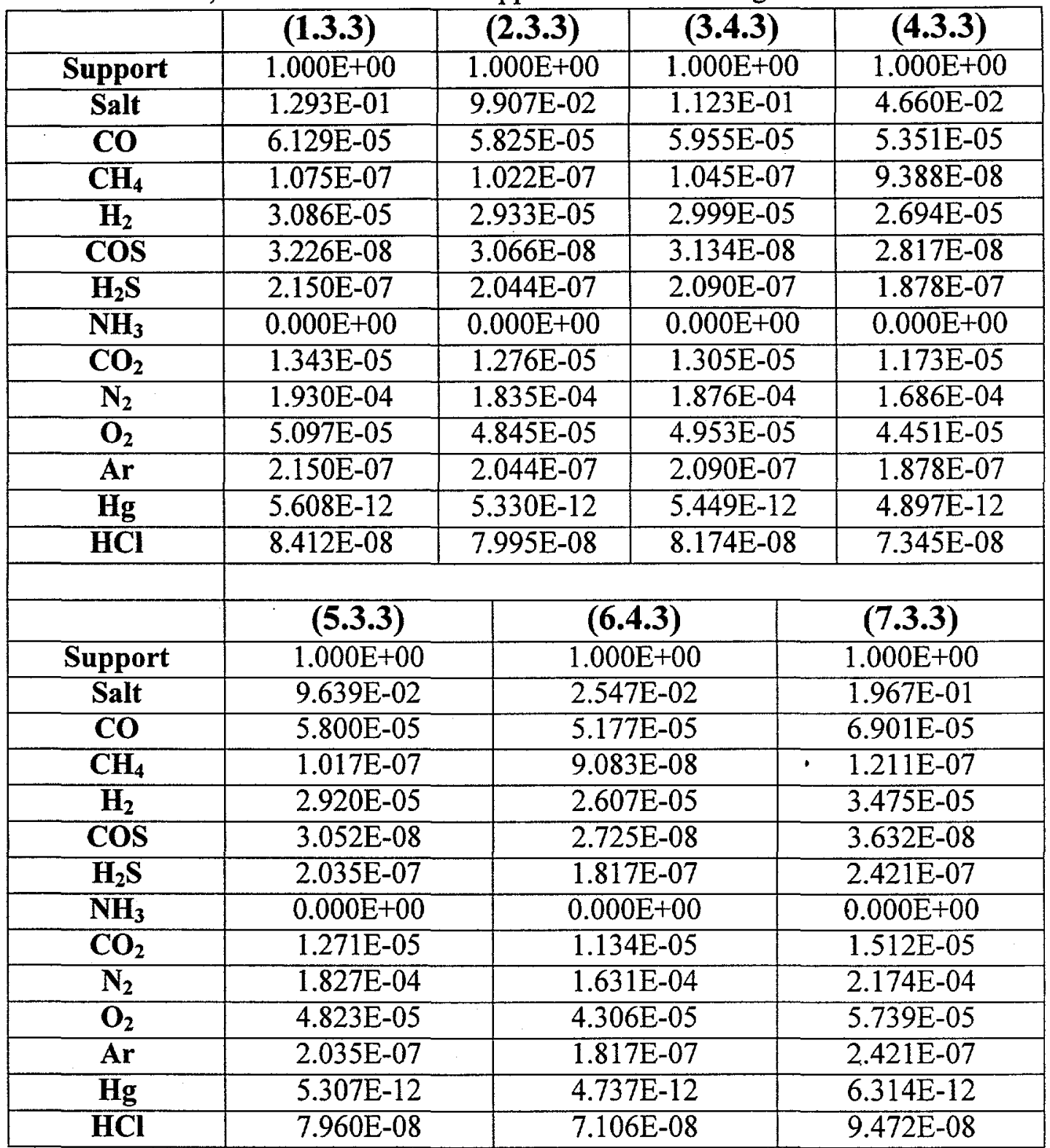


$\mathrm{SO}_{2}$ Mole Fraction vs Temperature for a Koppers-Totzek Gasifier with various Salts/Supports under Oxidizing Conditions

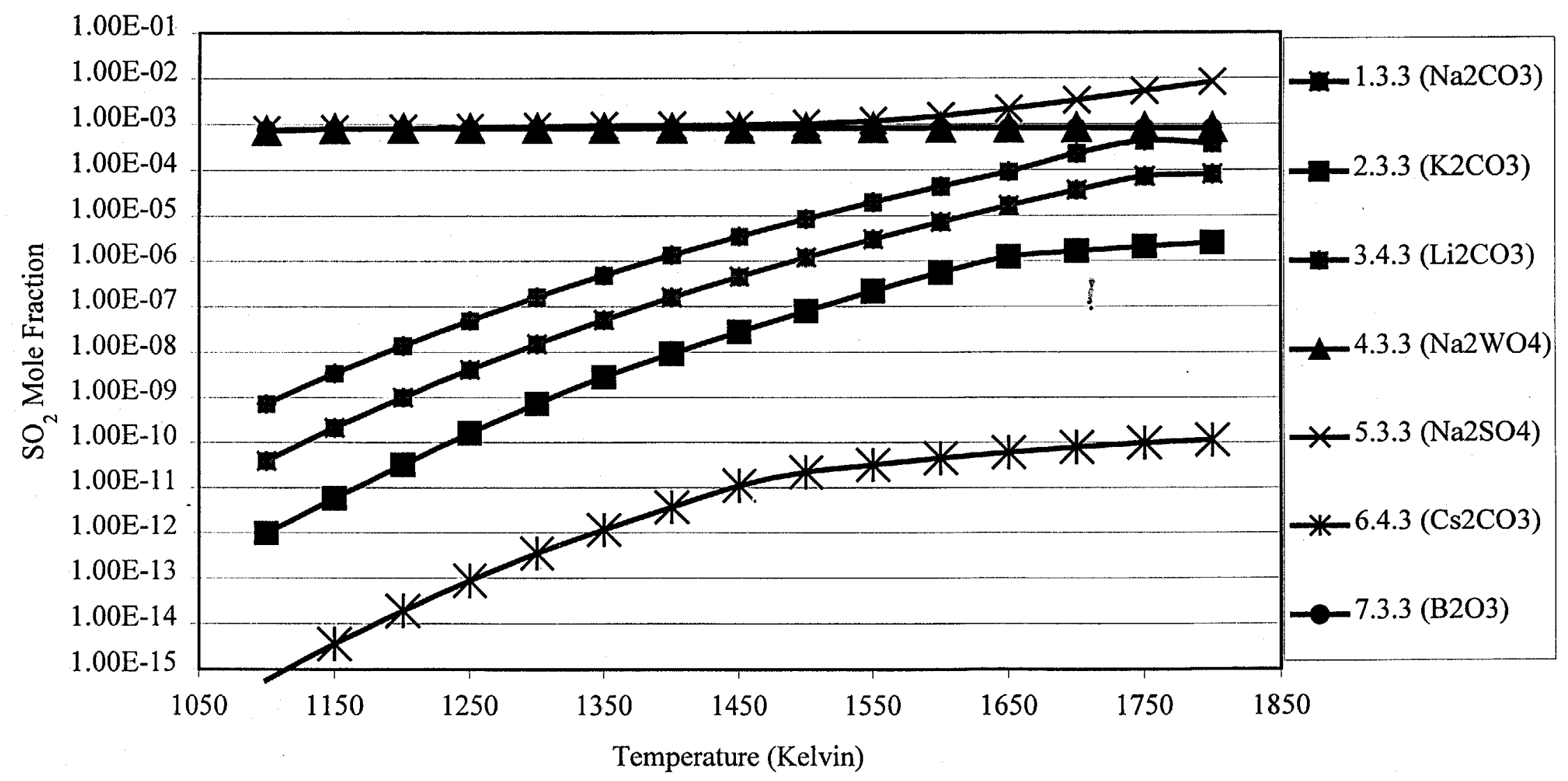

Figure A.6 $\mathrm{SO}_{2}$ Mole Fraction for a Koppers-Totzek Off-Gas and High Temperature Salts with a Non-Reactive Support under Oxidizing Conditions. 
Sodium Gaseous Species vs Temperature for a Koppers-Totzek Gasifier in Oxidizing Conditions (1.3.3)

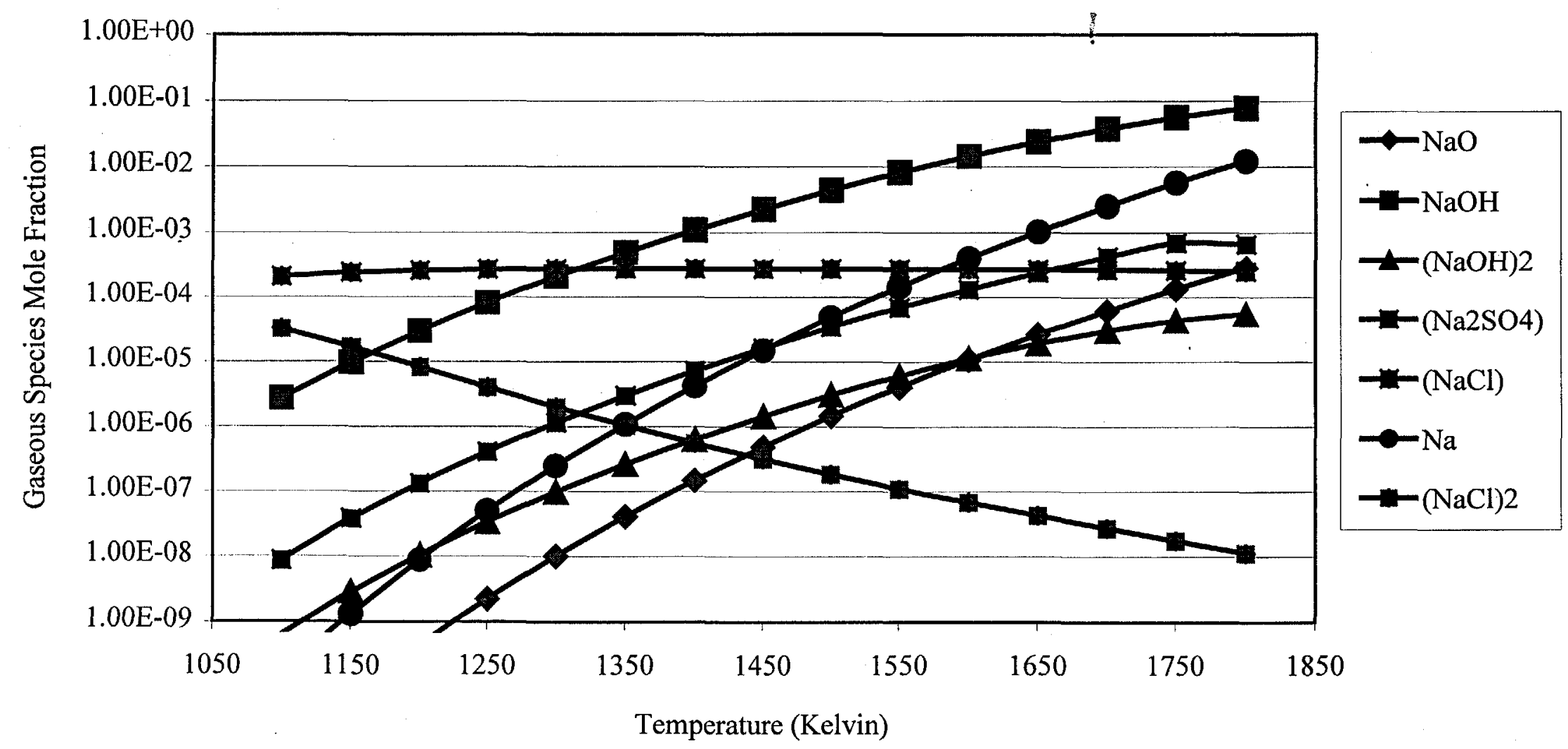

Figure A.7 Sodium Gaseous Species Mole Fraction for $\mathrm{Na}_{2} \mathrm{CO}_{3}$ and a Koppers-Totzek Off-Gas with $\mathrm{ZrO}_{2}$ under Oxidizing Conditions (1.3.3). 
Potassium Gaseous Species vs Temperature for a Koppers-Totzek Off-Gas in Oxidizing Conditions (2.3.3)

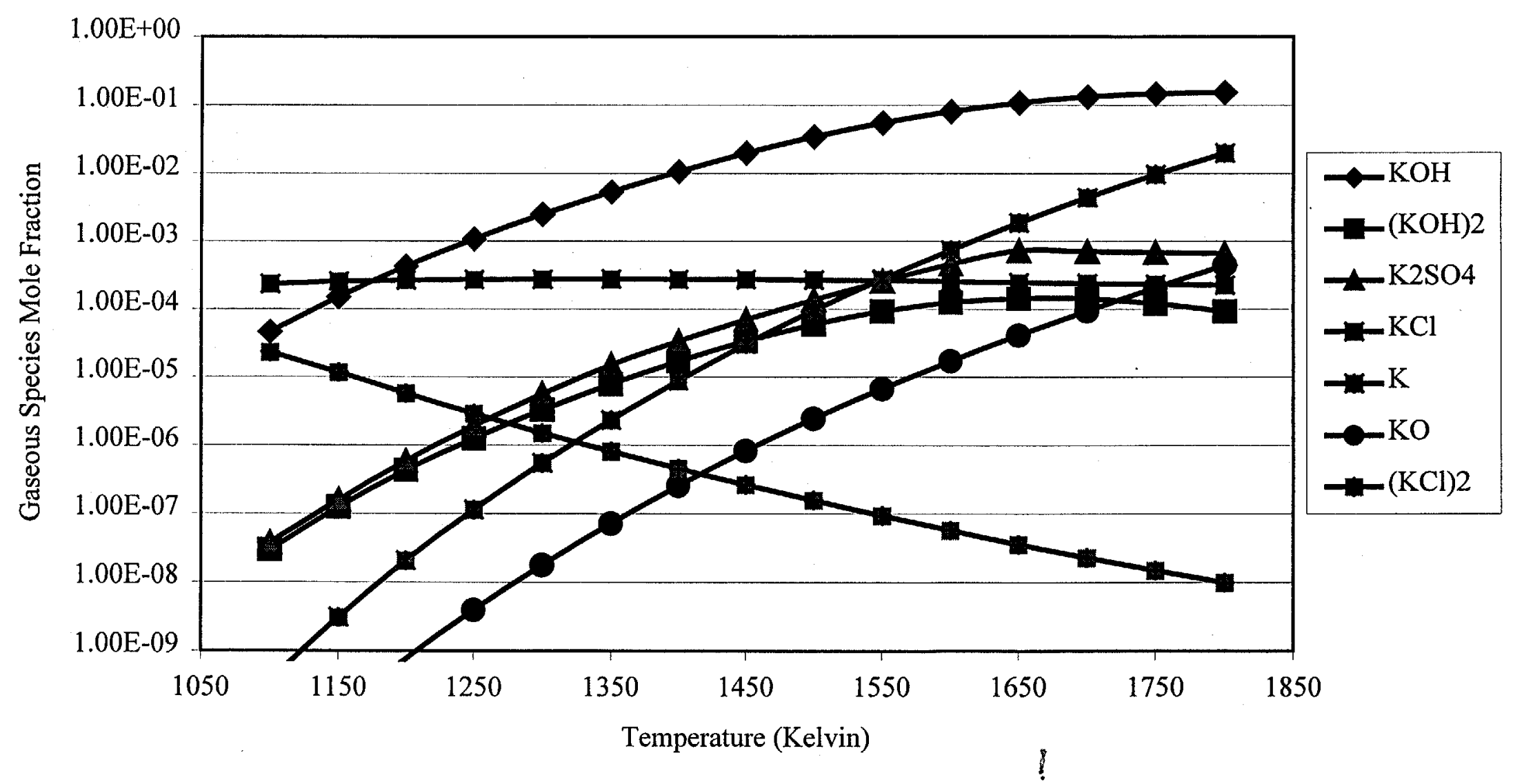

Figure A.8 Potassium Gaseous Species Mole Fraction for $\mathrm{K}_{2} \mathrm{CO}_{3}$ and a Koppers-Totzek Off-Gas with $\mathrm{ZrO}_{2}$ under Oxidizing Conditions (2.3.3). 
Lithium Gaseous Species vs Temperature from a Koppers-Totzek Off-Gas in Oxidizing Conditions for (3.4.3)

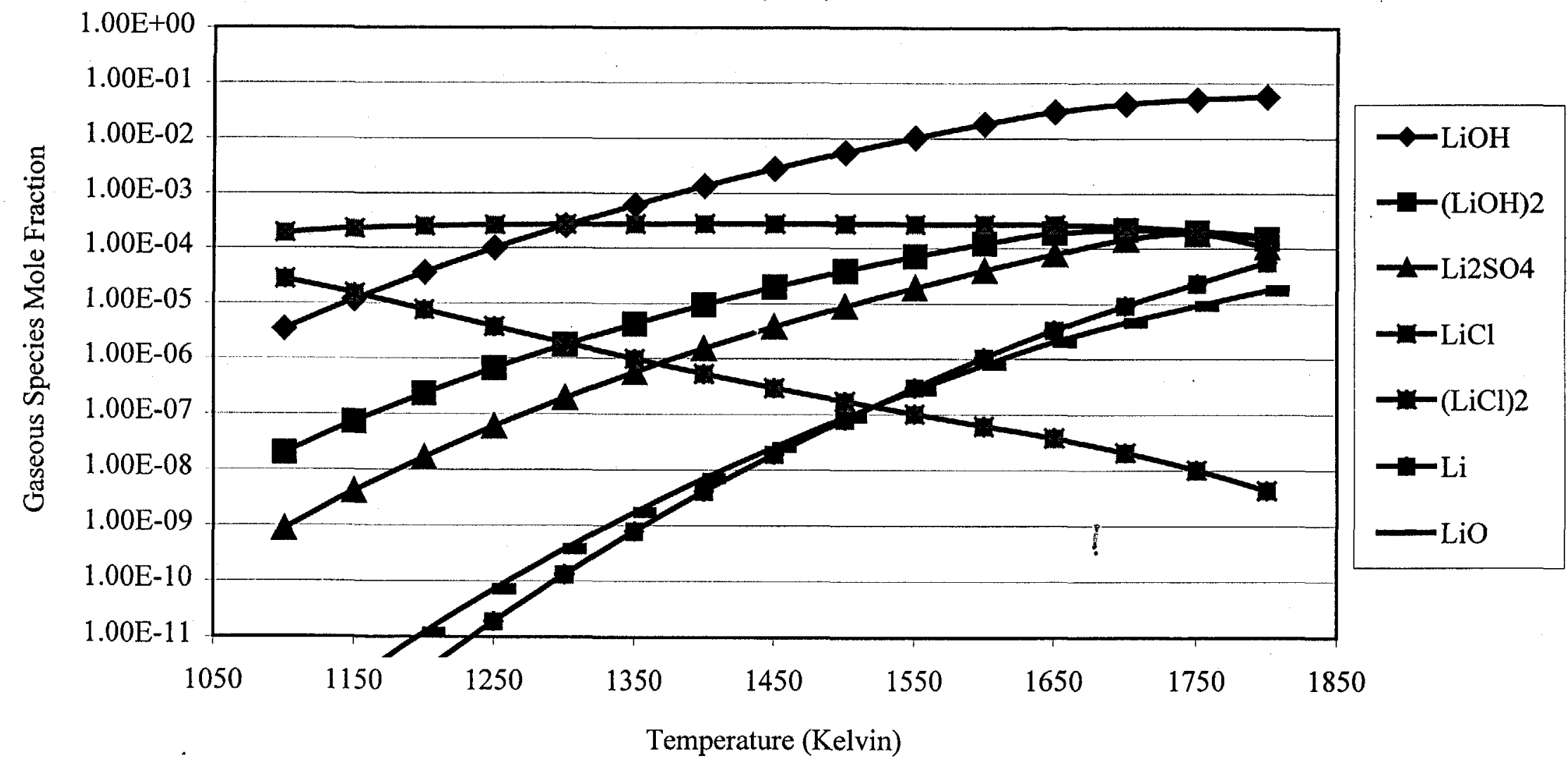

Figure A.9 Lithium Gaseous Species Mole Fraction for $\mathrm{Li}_{2} \mathrm{CO}_{3}$ and a Koppers-Totzek Off-Gas with $\mathrm{NiO}$ under Oxidizing Conditions (3.4.3). 
Cesium Gaseous Species vs Temperature for a Koppers-Totzek Gasifier in Oxidizing Conditions (6.4.3)

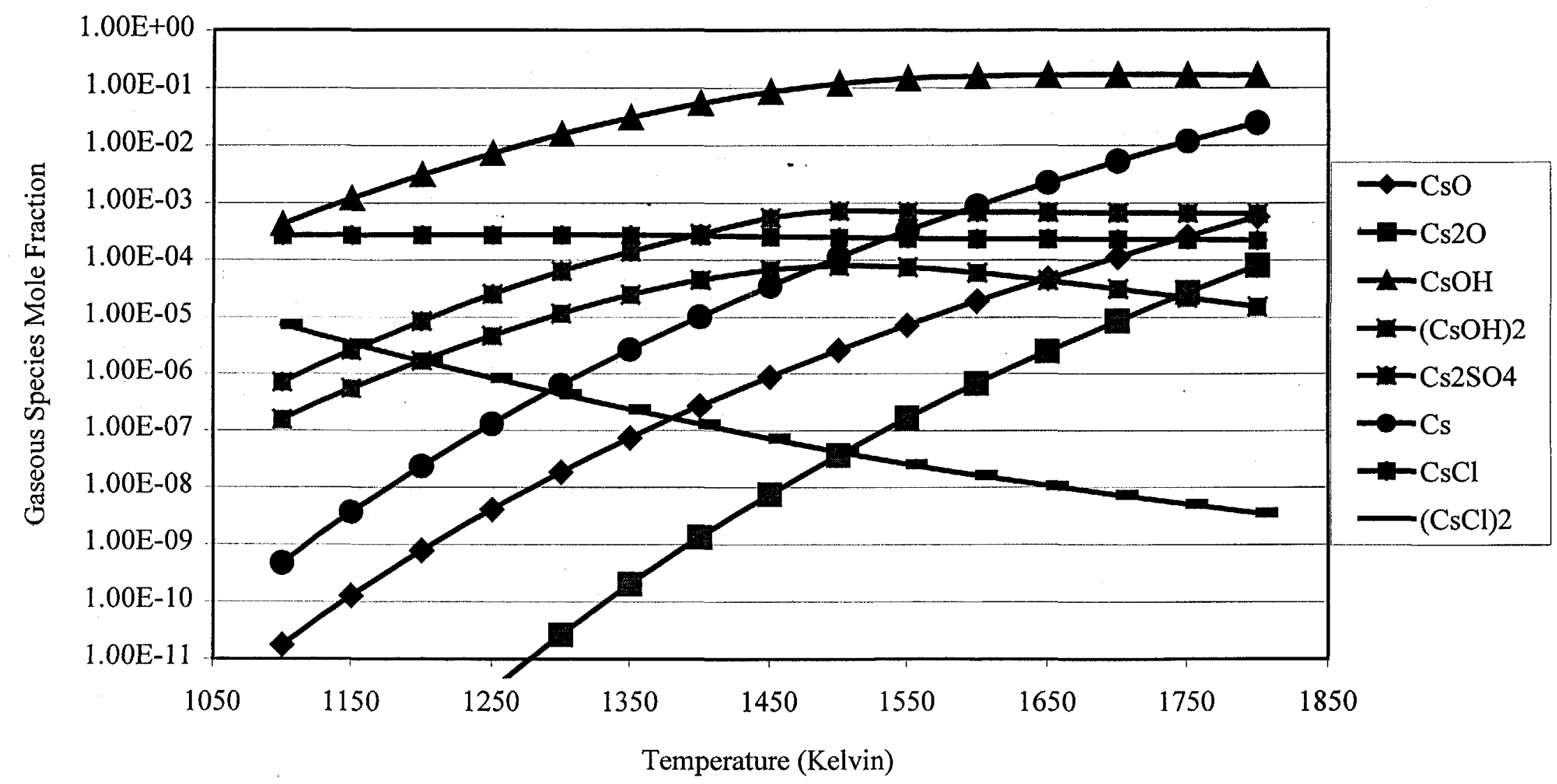

Figure A.10 Cesium Gaseous Species Mole Fraction for $\mathrm{Cs}_{2} \mathrm{CO}_{3}$ a Koppers-Totzek Off-Gas with $\mathrm{NiO}$ under Oxidizing Conditions (6.4.3) 
Since $\mathrm{K}_{2} \mathrm{CO}_{3}$ was the most effective salt for capturing the sulfur, the next logical step was to see how this salt behaved with the other supports. $\mathrm{K}_{2} \mathrm{CO}_{3}$ was run with all supports listed in Table A.1. Even the supports that reacted with $\mathrm{K}_{2} \mathrm{CO}_{3}$, as seen in Table A.4, were used to demonstrate some of the undesirable characteristics of these systems. The FACT entering molar ratios are listed in Table A.8. Figure A.11 shows the $\mathrm{SO}_{2}$ concentrations for $\mathrm{K}_{2} \mathrm{CO}_{3}$ simulations with different supports. $\mathrm{K}_{2} \mathrm{CO}_{3}$ reacts with all of the supports shown in yellow and green, but, it does not react with the supports shown in red and blue. For all of the non-reactive supports $\left(\mathrm{ZrO}_{2}\right.$, $\left.\mathrm{NiO}, \mathrm{Fe}_{2} \mathrm{O}_{3}, \mathrm{CaO}, \mathrm{Ca}_{3}\left(\mathrm{PO}_{4}\right)_{2}\right)$ the $\mathrm{SO}_{2}$ concentration is essentially the same.

There is an exception for $\mathrm{Fe}_{2} \mathrm{O}_{3}$ at temperatures above $1700 \mathrm{~K}$. Just above $1700 \mathrm{~K}, \mathrm{Fe}_{2} \mathrm{O}_{3}$ is no longer stable and decomposes into oxygen and iron. The large amount of oxygen released when iron oxide decomposes dramatically dilutes the gas phase concentration of $\mathrm{SO}_{2}$. The actual number of moles of $\mathrm{SO}_{2}$ present in the gas phase remains the same.

The reactive supports failed to capture any of the sulfur in the liquid or solid phase with the exception of $\mathrm{TiO}_{2}$ at low temperatures. In the case of $\mathrm{TiO}_{2}$, a limited amount of sulfur was captured as $\mathrm{K}_{2} \mathrm{SO}_{4}$ (s) up until $1250 \mathrm{~K}$. At $1250 \mathrm{~K}, \mathrm{~K}_{2} \mathrm{SO}_{4}$ (s) in this system is no longer stable. The reason the $\mathrm{SO}_{2}$ concentration for the reactive systems is lower compared to the systems where no salt or support was present is because the potassium carbonate decomposes into $\mathrm{CO}_{2}$ when the potassium carbonate reacts with the support to form a glassy compound. The decomposition of potassium carbonate dilutes the gas phase with $\mathrm{CO}_{2} . \mathrm{CO}_{2}$ 's mole fraction in the gas phase for the reactive supports is approximately 0.99 , except when the support is WC. In general, the carbonates are unstable with $\mathrm{SiO}_{2}, \mathrm{Al}_{2} \mathrm{O}_{3}, \mathrm{TiO}_{2}$, and $\mathrm{WC}$, as shown earlier in Table A.4.

Initially, from Figure A.11, it appears that WC captures a great deal of sulfur in the gas phase even at elevated temperatures. The reason the $\mathrm{SO}_{2}$ concentration is so low stems from the fact that oxygen reacts with a small portion of WC to form $\mathrm{O}^{2} \mathrm{~W}(\mathrm{OH})^{2}(\mathrm{~g})$. This causes the system to behave is if under reduced conditions. Under reducing conditions, the sulfur would remain as hydrogen sulfide, which is what is observed in this case. The fact that, $\mathrm{H}_{2} \mathrm{~S}$ 's mole fraction was around $10^{-4}$ in the lower temperature region of this system, along with the absence of $\mathrm{K}_{2} \mathrm{SO}_{4}$ in either the liquid or solid phase, demonstrates that this system is ineffective for capturing sulfur even though the $\mathrm{SO}_{2}$ concentration is extremely low.

Figures A.12-A.15 give significant gaseous species concentrations for the non-reactive support systems. From these plots, the increased production of $\mathrm{NO}_{\mathrm{x}}$ with increasing temperature is observed. The concentration levels are consistent with those found for the cases where no salt or support was present. There are high concentrations of nitrogen, carbon dioxide, and water present in all of the systems, which is indicative of the products of a combustion reaction. There also is an appreciable amount of oxygen present, which is expected based on the system being designed for $10 \%$ excess oxygen. Unfortunately, mercury is not present in either the solid or liquid phase. Its concentration is consistent with that seen for when no salt or support is present. Mercury at high temperature does remain in its zero oxidation state, which is consistent with the literature on the subject. 
Figures A.15-18 show the salt related gaseous species for the non-reactive support systems. There are two important trends to take away from these figures. First, the amount of the undesirable salt species, in general, increases with temperature. The second very important concept is that for the non-reactive systems the salt speciation in the gas phase is not a function of the support material used. This concept will reduce the amount of data that needs to be reported for simulations run at lower temperatures with the nitrates in the following section. 
Table A.8 FACT entering Molar Ratios for $\mathrm{K}_{2} \mathrm{CO}_{3}$ and a Koppers-Totzek Off-Gas with various Supports under High Temperature Oxidizing Conditions.

\begin{tabular}{|c|c|c|c|c|}
\hline & $(\mathbf{2 . 1 . 3 )}$ & $(2.2 .3)$ & $(2.4 .3)$ & $(2.5 .3)$ \\
\hline Support & $1.000 \mathrm{E}+00$ & $1.000 \mathrm{E}+00$ & $1.000 \mathrm{E}+00$ & $1.000 \mathrm{E}+00$ \\
\hline Salt & $4.830 \mathrm{E}-02$ & $8.197 \mathrm{E}-02$ & $6.005 \mathrm{E}-02$ & $1.284 \mathrm{E}-01$ \\
\hline $\mathrm{CO}$ & $5.366 \mathrm{E}-05$ & $5.664 \mathrm{E}-05$ & $5.467 \mathrm{E}-05$ & $6.119 \mathrm{E}-05$ \\
\hline $\mathbf{C H}_{4}$ & $9.414 \mathrm{E}-08$ & $9.937 \mathrm{E}-08$ & $9.591 \mathrm{E}-08$ & $1.074 \mathrm{E}-07$ \\
\hline $\mathbf{H}_{2}$ & $2.702 \mathrm{E}-05$ & $2.852 \mathrm{E}-05$ & $2.753 \mathrm{E}-05$ & $3.081 \mathrm{E}-05$ \\
\hline $\mathrm{COS}$ & $2.824 \mathrm{E}-08$ & $2.981 \mathrm{E}-08$ & $2.877 \mathrm{E}-08$ & $3.221 \mathrm{E}-08$ \\
\hline $\mathrm{H}_{2} \mathrm{~S}$ & $1.883 \mathrm{E}-07$ & $1.987 \mathrm{E}-07$ & $1.918 \mathrm{E}-07$ & $2.147 \mathrm{E}-07$ \\
\hline $\mathrm{NH}_{3}$ & $0.000 \mathrm{E}+00$ & $0.000 \mathrm{E}+00$ & $0.000 \mathrm{E}+00$ & $0.000 \mathrm{E}+00$ \\
\hline $\mathrm{CO}_{2}$ & $1.176 \mathrm{E}-05$ & $1.241 \mathrm{E}-05$ & $1.198 \mathrm{E}-05$ & $1.341 \mathrm{E}-05$ \\
\hline $\mathbf{N}_{2}$ & $1.690 \mathrm{E}-04$ & $1.784 \mathrm{E}-04$ & 1.722E-04 & $1.927 \mathrm{E}-04$ \\
\hline $\mathbf{O}_{2}$ & $4.463 \mathrm{E}-05$ & $4.711 \mathrm{E}-05$ & $4.547 \mathrm{E}-05$ & $5.089 \mathrm{E}-05$ \\
\hline Ar & $1.883 \mathrm{E}-07$ & $1.987 \mathrm{E}-07$ & $1.918 \mathrm{E}-07$ & $2.147 \mathrm{E}-07$ \\
\hline Hg & $4.910 \mathrm{E}-12$ & $5.183 \mathrm{E}-12$ & $5.002 \mathrm{E}-12$ & $5.599 \mathrm{E}-12$ \\
\hline \multirow[t]{2}{*}{$\mathrm{HCl}$} & $7.365 \mathrm{E}-08$ & $7.774 \mathrm{E}-08$ & $7.504 \mathrm{E}-08$ & $8.399 \mathrm{E}-08$ \\
\hline & $(2.6 .3)$ & (2.7.3) & (2.8.3) & (2.9.3) \\
\hline Support & $1.000 \mathrm{E}+00$ & $1.000 \mathrm{E}+00$ & $1.000 \mathrm{E}+00$ & $1.000 \mathrm{E}+00$ \\
\hline Salt & $1.575 \mathrm{E}-01$ & $6.422 \mathrm{E}-02$ & $4.508 \mathrm{E}-02$ & $2.494 \mathrm{E}-01$ \\
\hline $\mathrm{CO}$ & $6.435 \mathrm{E}-05$ & $5.504 \mathrm{E}-05$ & $5.339 \mathrm{E}-05$ & $7.617 \mathrm{E}-05$ \\
\hline $\mathrm{CH}_{4}$ & $1.129 \mathrm{E}-07$ & $9.656 \mathrm{E}-08$ & $9.366 \mathrm{E}-08$ & $1.336 \mathrm{E}-07$ \\
\hline $\mathrm{H}_{2}$ & $3.240 \mathrm{E}-05$ & $2.771 \mathrm{E}-05$ & $2.688 \mathrm{E}-05$ & $3.835 \mathrm{E}-05$ \\
\hline COS & $3.387 \mathrm{E}-08$ & $2.897 \mathrm{E}-08$ & $2.810 \mathrm{E}-08$ & $4.009 \mathrm{E}-08$ \\
\hline $\mathrm{H}_{2} \mathrm{~S}$ & $2.258 \mathrm{E}-07$ & $1.931 \mathrm{E}-07$ & $1.873 \mathrm{E}-07$ & $2.673 \mathrm{E}-07$ \\
\hline $\mathrm{NH}_{3}$ & $0.000 \mathrm{E}+00$ & $0.000 \mathrm{E}+00$ & $0.000 \mathrm{E}+00$ & $0.000 \mathrm{E}+00$ \\
\hline $\mathrm{CO}_{2}$ & $1.410 \mathrm{E}-05$ & $1.206 \mathrm{E}-05$ & $1.170 \mathrm{E}-05$ & $1.669 \mathrm{E}-05$ \\
\hline$\overline{\mathbf{N}_{2}}$ & $2.027 \mathrm{E}-04$ & $1.733 \mathrm{E}-04$ & $1.681 \mathrm{E}-04$ & $2.399 \mathrm{E}-04$ \\
\hline $\mathbf{O}_{2}$ & $5.351 \mathrm{E}-05$ & $4.577 \mathrm{E}-05$ & $4.440 \mathrm{E}-05$ & $6.335 \mathrm{E}-05$ \\
\hline $\mathbf{A r}$ & $2.258 \mathrm{E}-07$ & $1.931 \mathrm{E}-07$ & $1.873 \mathrm{E}-07$ & $2.673 \mathrm{E}-07$ \\
\hline $\mathbf{H g}$ & $5.888 \mathrm{E}-12$ & $5.036 \mathrm{E}-12$ & $4.885 \mathrm{E}-12$ & $6.970 \mathrm{E}-12$ \\
\hline $\mathrm{HCl}$ & $8.831 \mathrm{E}-08$ & $7.554 \mathrm{E}-08$ & $7.327 \mathrm{E}-08$ & $1.045 \mathrm{E}-07$ \\
\hline
\end{tabular}


$\mathrm{SO}_{2}$ Mole Fraction vs Temperature for $\mathrm{K}_{2} \mathrm{CO}_{3}$ and a Koppers-Totzek Off-Gas with various Supports under Oxidizing Conditions

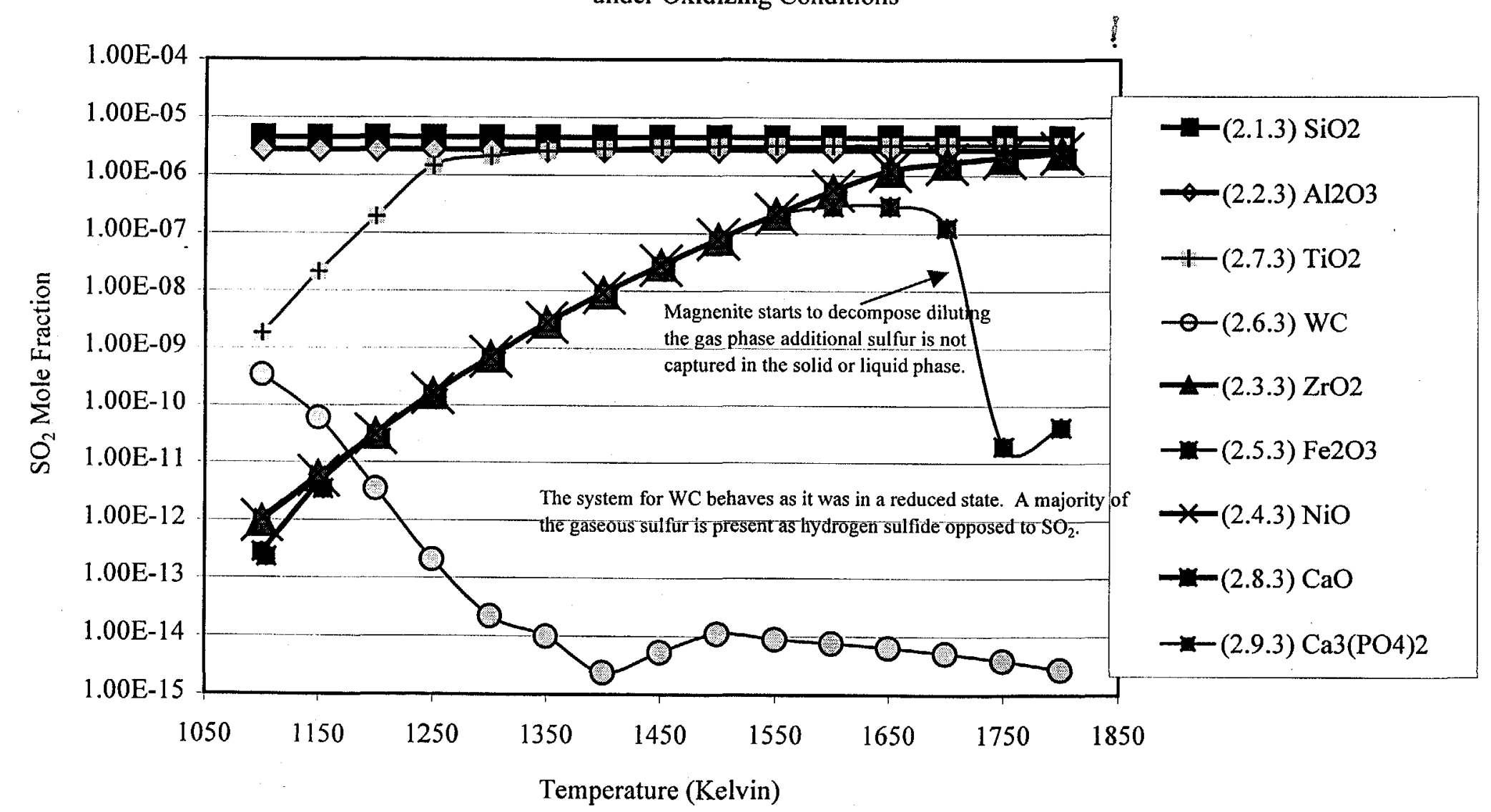

Figure A.11 $\mathrm{SO}_{2}$ Mole Fraction for $\mathrm{K}_{2} \mathrm{CO}_{3}$ and a Koppers-Totzek Off-Gas with various Supports under High Temperature Oxidizing Conditions. 
Significant Gaseous Species vs Temperature for $\mathrm{K}_{2} \mathrm{CO}_{3}$ and a Koppers-Totzek Off-Gas with NiO under Oxidizing Conditions (2.4.3)

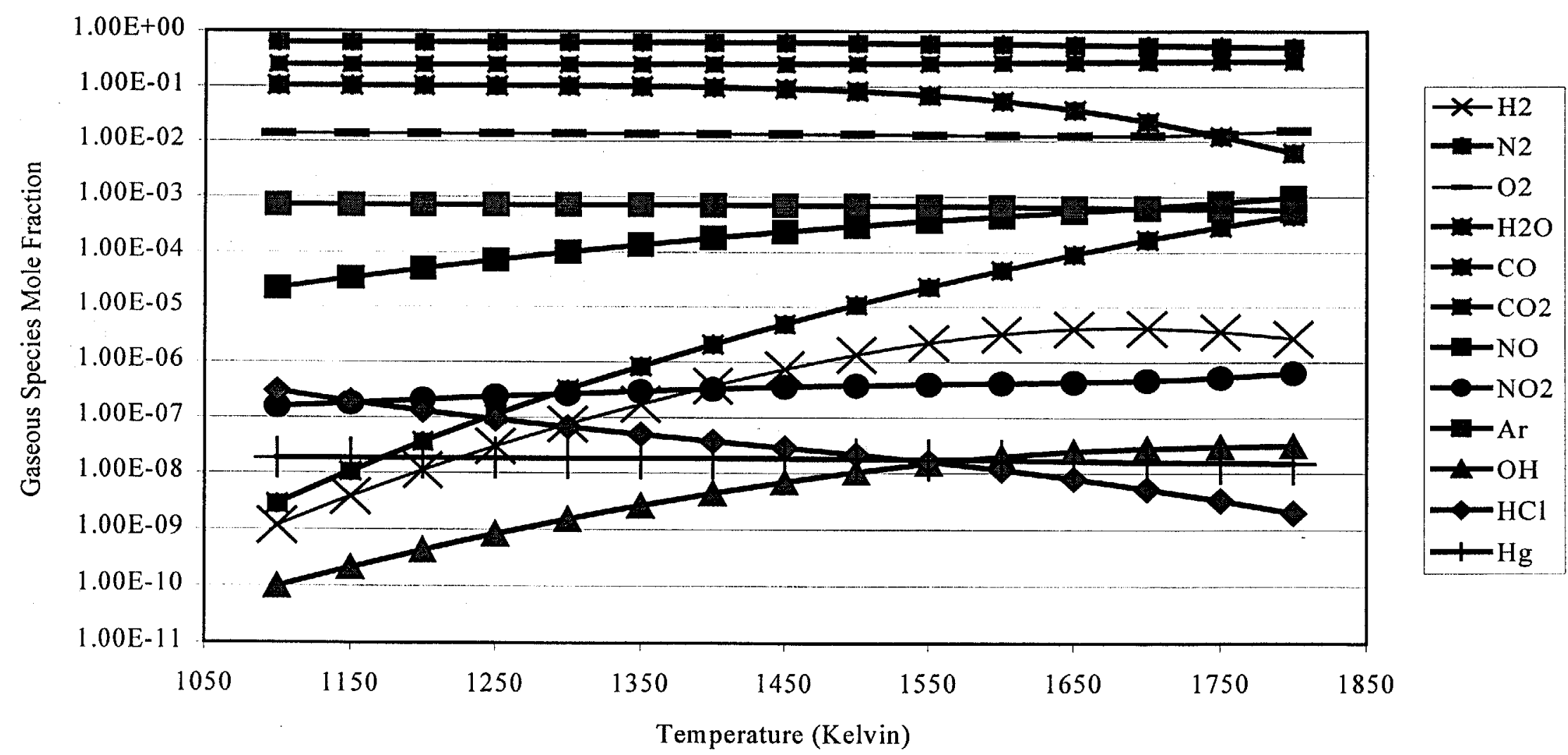

Figure A.12 Significant Gaseous Species Mole Fraction for $\mathrm{K}_{2} \mathrm{CO}_{3}$ and a Koppers-Totzek Off-Gas with NiO under Oxidizing Conditions (2.4.3). 


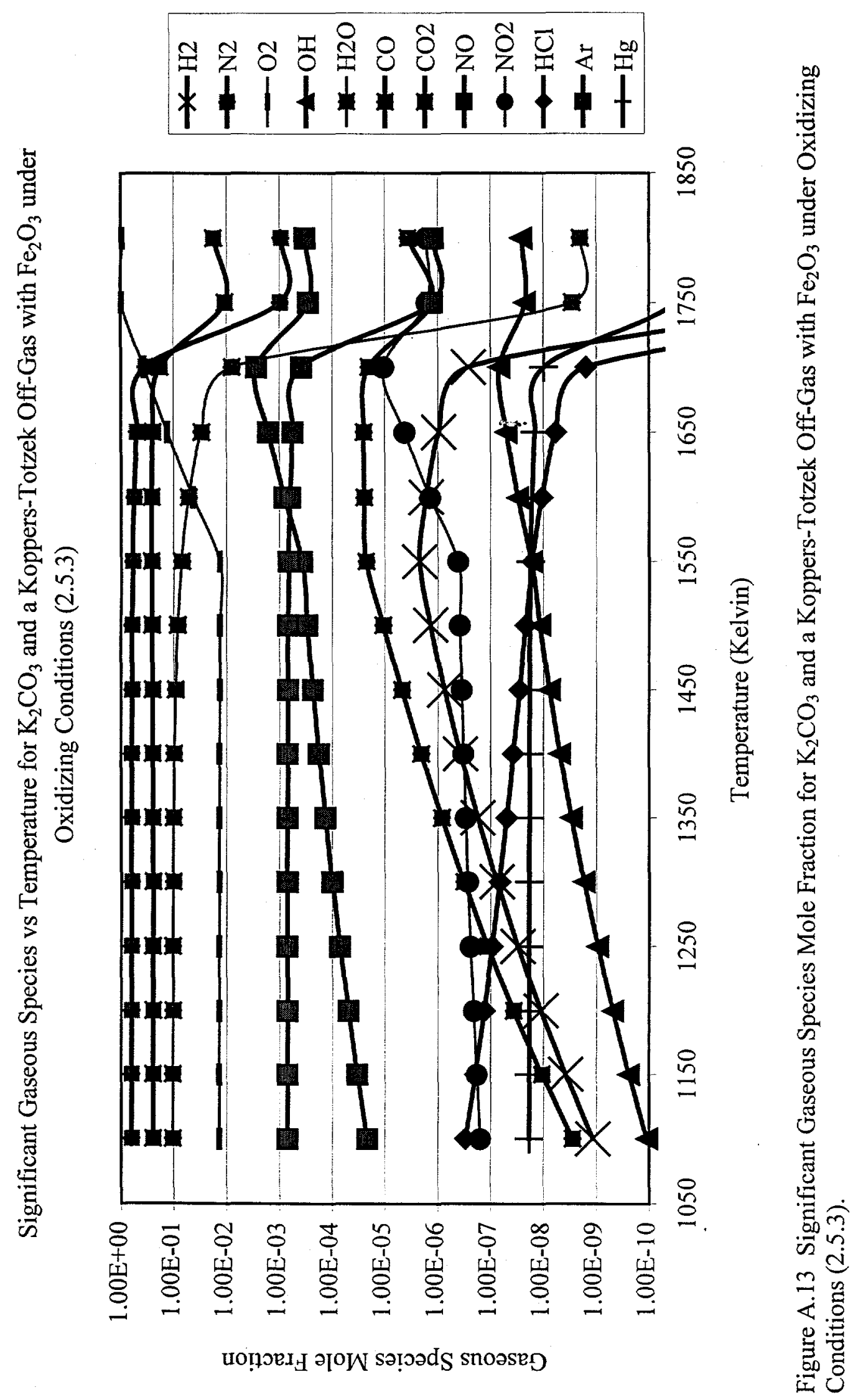


Significant Gaseous Species vs Temperature for $\mathrm{K}_{2} \mathrm{CO}_{3}$ and a Koppers-Totzek Off-Gas with $\mathrm{CaO}$ under Oxidizing Conditions (2.8.3)

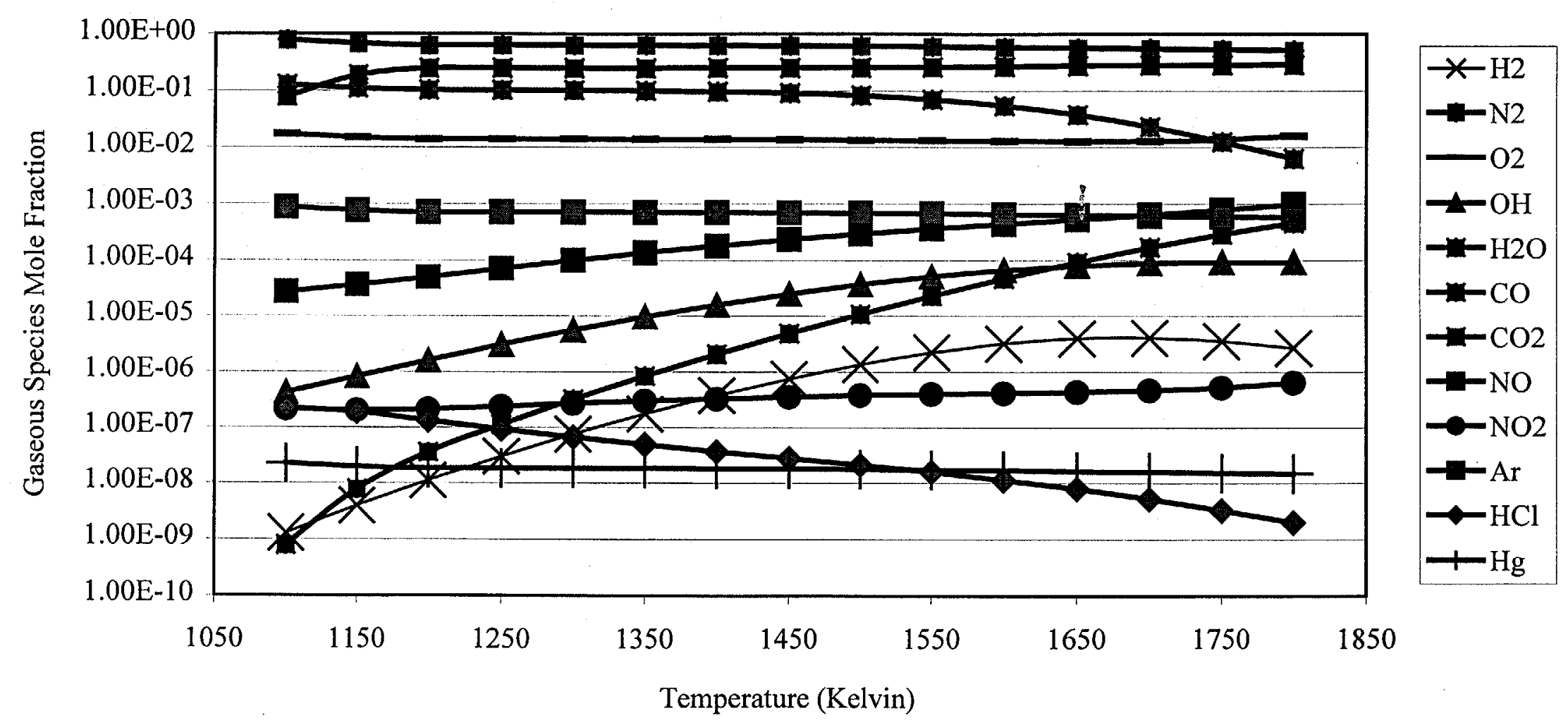

Figure A.14 Significant Gaseous Species Mole Fraction for $\mathrm{K}_{2} \mathrm{CO}_{3}$ and a Koppers-Totzek Off-Gas with $\mathrm{CaO}$ under Oxidizing Conditions (2.8.3). 
Significant Gaseous Species vs Temperature for $\mathrm{K}_{2} \mathrm{CO}_{3}$ and a Koppers-Totzek Off-Gas with $\mathrm{Ca}_{3}\left(\mathrm{PO}_{4}\right)_{2}$ under Oxidizing Conditions (2.9.3)

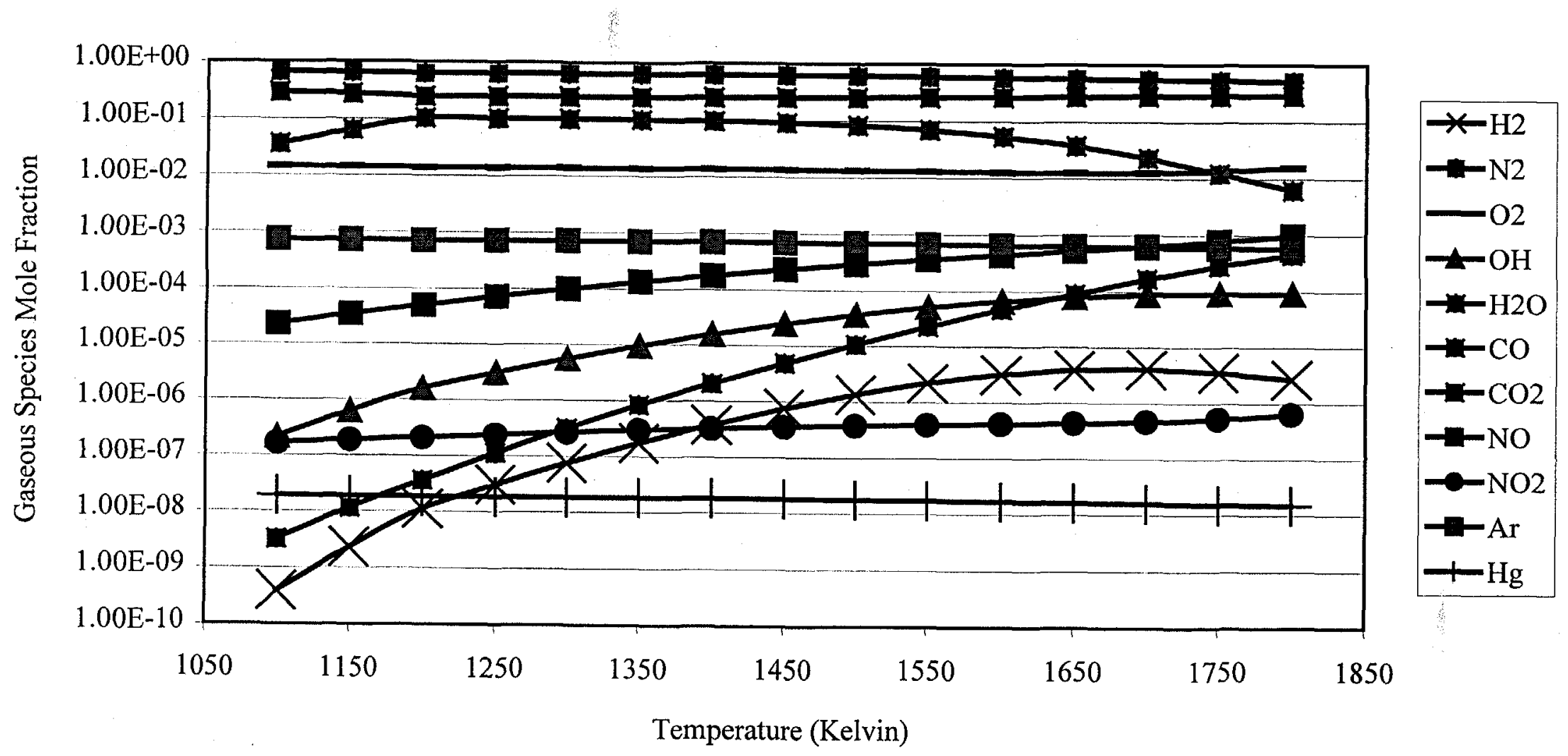

Figure A.15 Significant Gaseous Species Mole Fraction for $\mathrm{K}_{2} \mathrm{CO}_{3}$ and a Koppers-Totzek Off-Gas with $\mathrm{Ca}_{3}\left(\mathrm{PO}_{4}\right)_{2}$ under Oxidizing Conditions (2.9.3). 
Potassium Related Gaseous Species vs Temperature for $\mathrm{K}_{2} \mathrm{CO}_{3}$ and a Koppers-Totzek Off-Gas with NiO under Oxidizing Conditions (2.4.3)

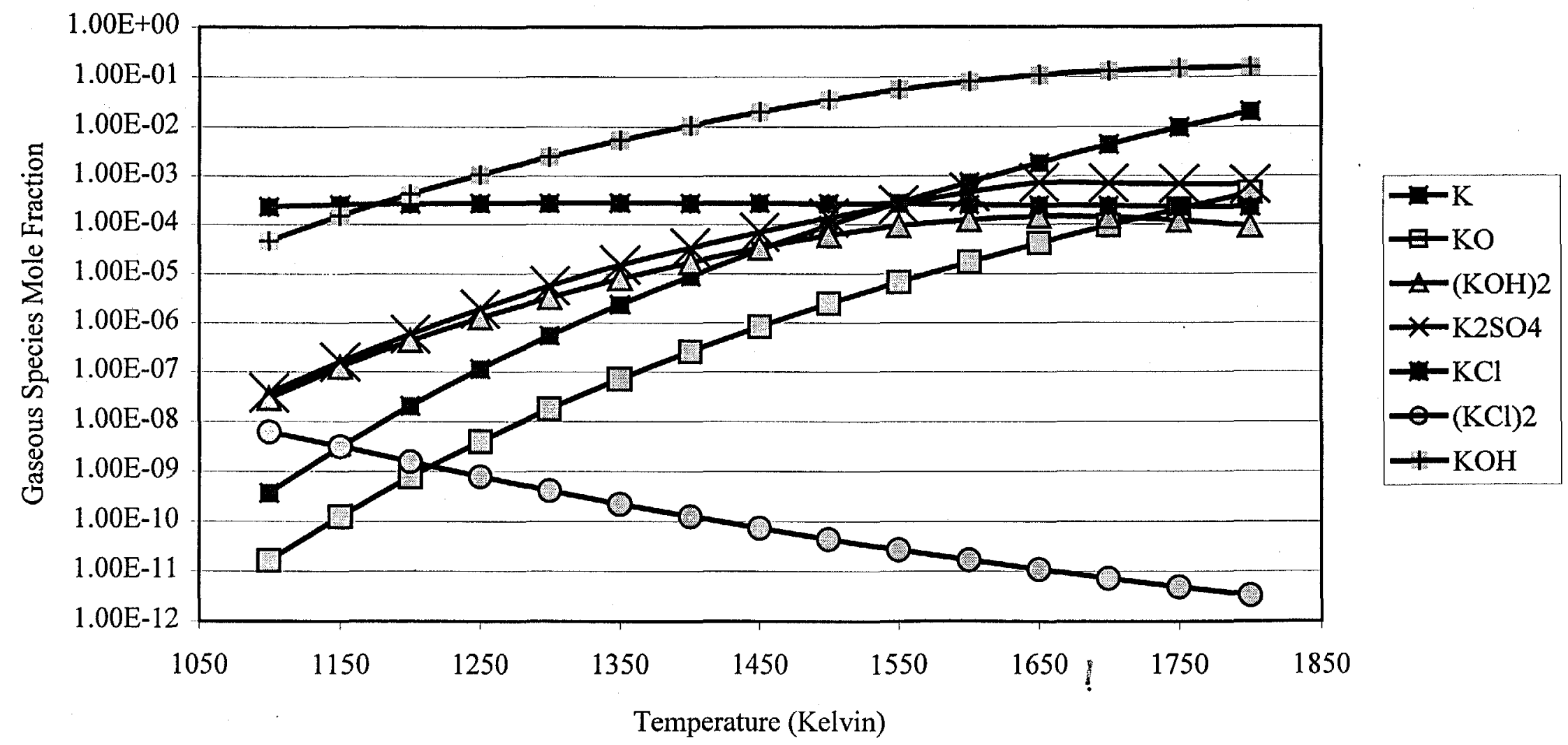

Figure A.16 Potassium Gaseous Species Mole Fraction for $\mathrm{K}_{2} \mathrm{CO}_{3}$ and a Koppers-Totzek Off-Gas with NiO under Oxidizing Conditions (2.4.3). 
Potassium Related Gaseous Species vs Temperature for $\mathrm{K}_{2} \mathrm{CO}_{3}$ and a Koppers-Totzek Off-Gas with $\mathrm{Fe}_{2} \mathrm{O}_{3}$ under Oxidizing Conditions (2.5.3)

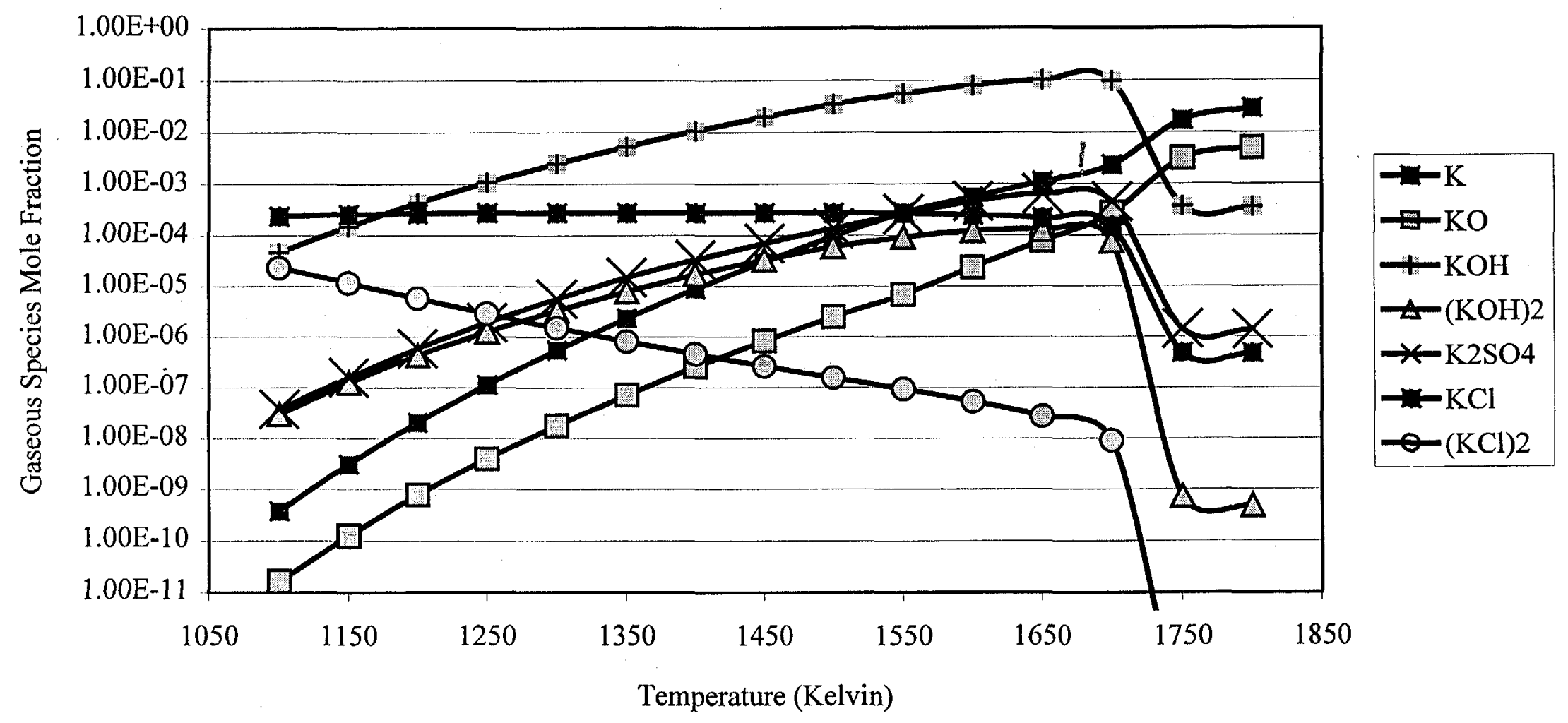

Figure A.17 Potassium Gaseous Species Mole Fraction for $\mathrm{K}_{2} \mathrm{CO}_{3}$ and a Koppers-Totzek Off-Gas with $\mathrm{Fe}_{2} \mathrm{O}_{3}$ under Oxidizing Conditions (2.5.3). 
Potassium Related Gaseous Species vs Temperature for $\mathrm{K}_{2} \mathrm{CO}_{3}$ and a Koppers-Totzek Off-Gas with $\mathrm{CaO}$ under Oxidizing Conditions (2.8.3)

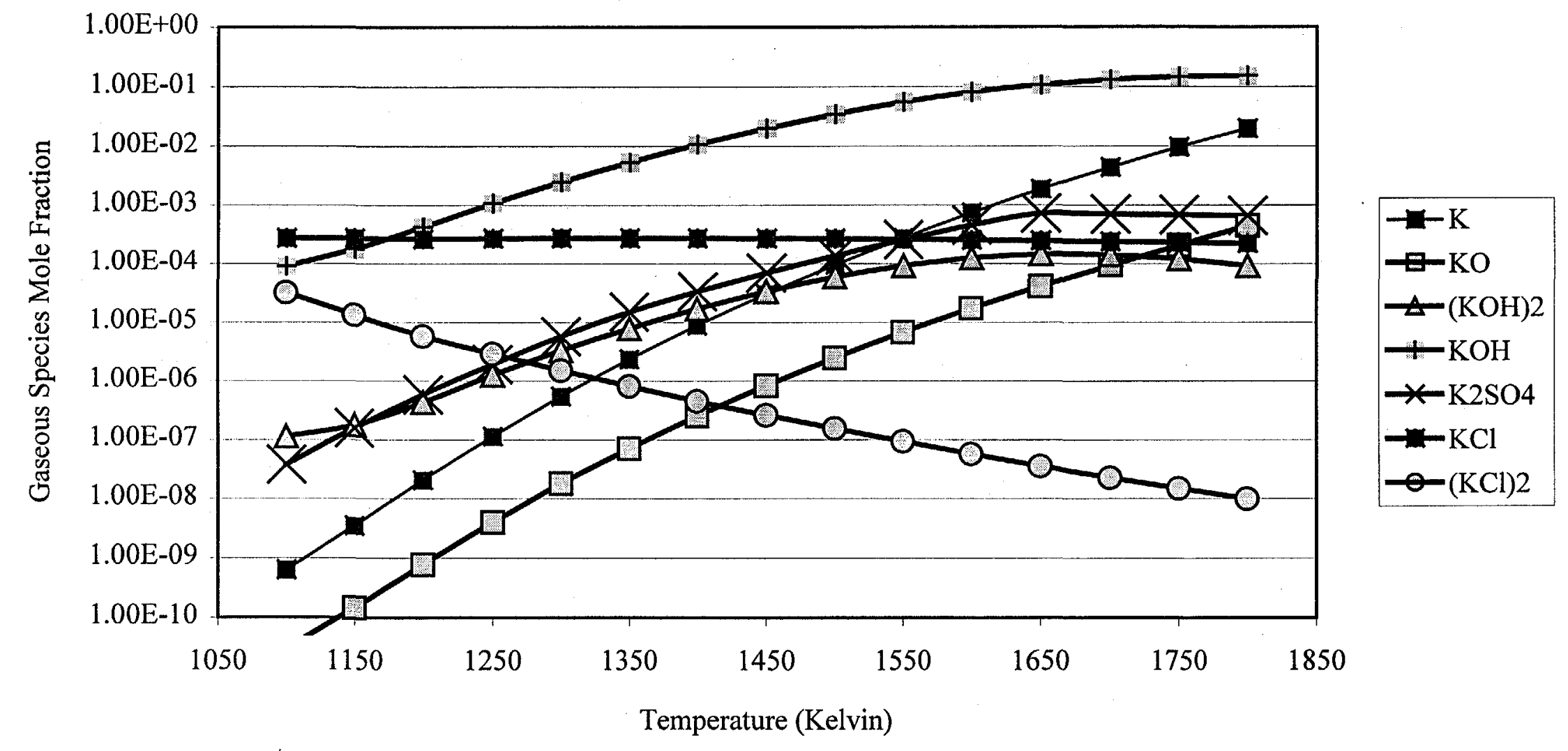

Figure A.18 Potassium Gaseous Species Mole Fraction for $\mathrm{K}_{2} \mathrm{CO}_{3}$ and a Koppers-Totzek Off-Gas with $\mathrm{CaO}$ under Oxidizing Conditions (2.8.3). 
Potassium Related Gaseous Species vs Temperature for $\mathrm{K}_{2} \mathrm{CO}_{3}$ and a Koppers-Totzek Off-Gas with $\mathrm{Ca}_{3}\left(\mathrm{PO}_{4}\right)_{2}$ under Oxidizing Conditions (2.9.3)

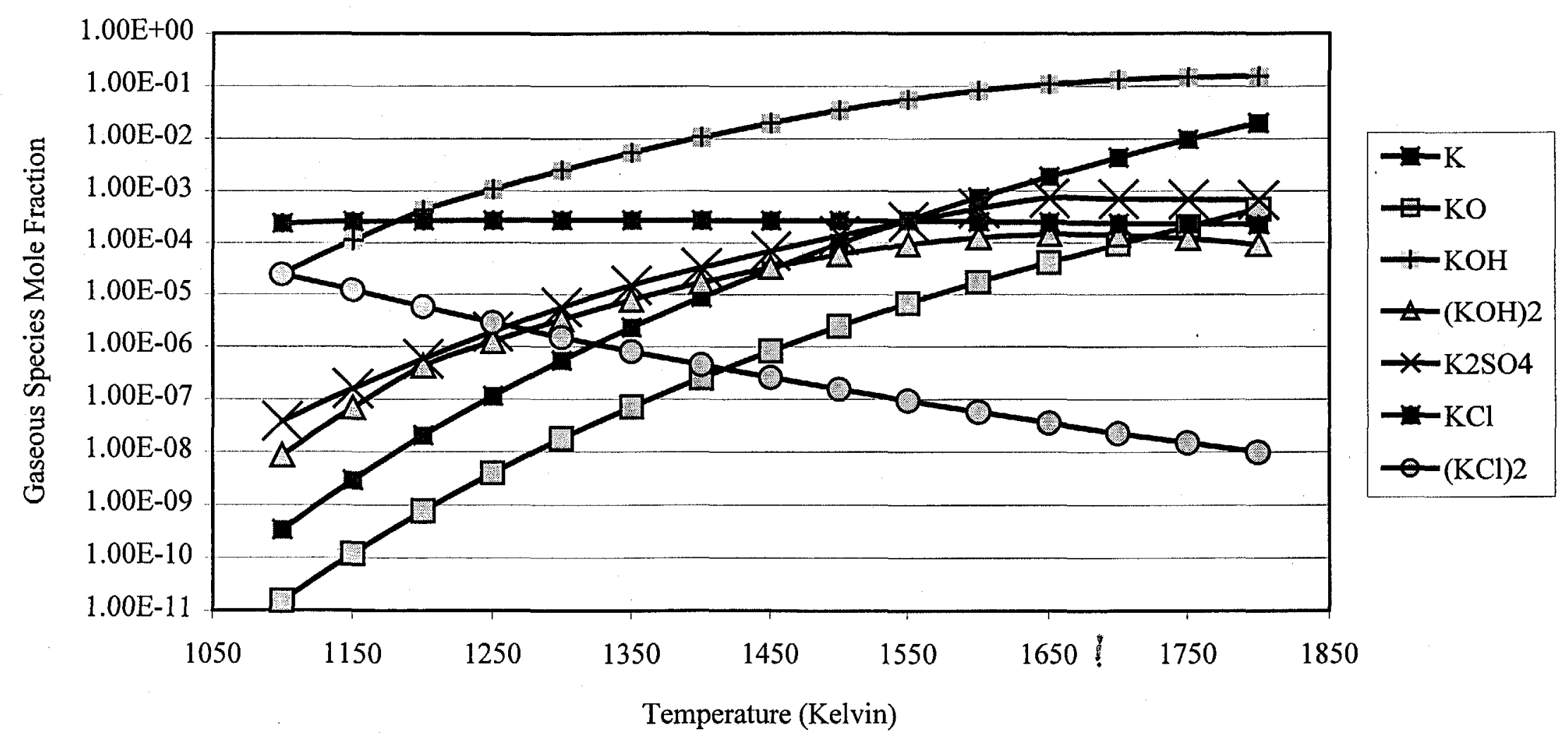

Figure A.19 Potassium Gaseous Species Mole Fraction for $\mathrm{K}_{2} \mathrm{CO}_{3}$ and a Koppers-Totzek Off-Gas with $\mathrm{Ca}_{3}\left(\mathrm{PO}_{4}\right)_{2}$ under Oxidizing Conditions (2.9.3). 
A.6b) High Temperature/Reducing Condition Simulations

Sulfur capture in the liquid and solid phases still occurred at high temperature even without the addition of oxygen to the system. In the cases where molten carbonates were used small amounts of $\mathrm{K}_{2} \mathrm{SO}_{4}$ formed reducing the overall amount of sulfur left in the gas phase. For this series of simulations, the off-gas from a Lurgi gasifier was used to generate the entering FACT molar ratio inputs, listed in Table A.9.

Initially, all of the salts and a non-reactive support were reacted with to determine what happened to the sulfur, $\mathrm{NO}_{\mathrm{x}}$, and mercury. Figures A.20 and A.21 give $\mathrm{H}_{2} \mathrm{~S}$ and $\mathrm{SO}_{2}$ mole fractions as a function of the different high temperature salts. Due to the oxygen deficiency, there was still a large amount of hydrogen sulfide present in the gas along with significant amounts of $\mathrm{SO}_{2}$. Similar to the results for high temperature in an oxygen rich environment the salts: $\mathrm{Na}_{2} \mathrm{WO}_{4}, \mathrm{Na}_{2} \mathrm{SO}_{4}$, and $\mathrm{B}_{2} \mathrm{O}_{3}$ fail to capture sulfur in the solid or liquid phase. The carbonates on the other hand do indeed capture sulfur as a sulfate, except $\mathrm{Li}_{2} \mathrm{CO}_{3}$ In this case, a majority of the sulfur in fact reacts with the support to form $\mathrm{Ni}_{3} \mathrm{~S}_{2}$ (liquid) up until $1250 \mathrm{~K}$. After $1250 \mathrm{~K}, \mathrm{Li}_{2} \mathrm{SO}_{4}$ does form for about another $50 \mathrm{~K}$ until it is no longer stable and sulfur is no longer found in the liquid or solid phase. This accounts for the large increase of $\mathrm{SO}_{2}$ in Figure A.21 for $\mathrm{Li}_{2} \mathrm{CO}_{3} . \mathrm{K}_{2} \mathrm{CO}_{3}$ appears to do the best job capturing the sulfur in light of the suspect thermodynamic data for $\mathrm{Cs}_{2} \mathrm{CO}_{3}$. Even though some of the sulfur is captured, the $\mathrm{H}_{2} \mathrm{~S}$ and $\mathrm{SO}_{2}$ concentrations are greater than the ppm-v level except for $\mathrm{K}_{2} \mathrm{CO}_{3}$ below $1150 \mathrm{~K}$.

The other concern with these systems arises from the low $\mathrm{CO}$ and $\mathrm{H}_{2}$ concentrations. Figure A.22 shows significant gaseous species concentrations as a function of temperature for system (2.3.1). It looks like a significant portion of the $\mathrm{H}_{2}$ and $\mathrm{CO}$ was oxidized to form $\mathrm{H}_{2} \mathrm{O}$ and $\mathrm{CO}_{2}$. Unless these oxidation reactions are somehow kinetically limited, there is no point in using this system in conjunction with a molten carbonate fuel cell. In the following section discussion will focus on where the oxygen comes from that causes the gas streams' oxidation. This same phenomenon was observed for all of the carbonate salts tested. For $\mathrm{Na}_{2} \mathrm{WO}_{4}$, $\mathrm{Na}_{2} \mathrm{SO}_{4}$, and $\mathrm{B}_{2} \mathrm{O}_{3}$, the main gas phase constituents were still $\mathrm{CO}$ and $\mathrm{H}_{2}$, but as previously mentioned these salts failed to capture any sulfur. Figure A.23 gives the salt related gaseous species output for system (2.3.1) Again, the amount of salt species present in the gas phase increases with temperature, and is essentially the same for all of the $\mathrm{K}_{2} \mathrm{CO}_{3}$ systems in this section. $\mathrm{K}_{2} \mathrm{SO}_{4}(\mathrm{~g})$ reaches the ppm level around $1250 \mathrm{~K}$. 
Table A.9 FACT entering Molar Ratios for High Temperature Salts, a Lurgi Off-Gas, and a Non-Reactive Support under Reducing Conditions.

\begin{tabular}{|c|c|c|c|c|}
\hline & (1.3.1) & (2.3.1) & (3.4.1) & $\overline{(4.3 .1)}$ \\
\hline Support & $1.000 \mathrm{E}+00$ & $1.000 \mathrm{E}+00$ & $1.000 \mathrm{E}+00$ & $1.000 \mathrm{E}+00$ \\
\hline Salt & $1.770 \mathrm{E}-01$ & $8.916 \mathrm{E}-02$ & $1.011 \mathrm{E}-01$ & $4.194 \mathrm{E}-02$ \\
\hline CO & $4.396 \mathrm{E}-05$ & $3.783 \mathrm{E}-05$ & $3.858 \mathrm{E}-05$ & $3.506 \mathrm{E}-05$ \\
\hline $\mathrm{CH}_{4}$ & $4.054 \mathrm{E}-05$ & $3.488 \mathrm{E}-05$ & $3.557 \mathrm{E}-05$ & $3.233 \mathrm{E}-05$ \\
\hline$\overline{\mathbf{H}_{2}}$ & $1.642 \mathrm{E}-04$ & $1.413 \mathrm{E}-04$ & $1.441 \mathrm{E}-04$ & $1.310 \mathrm{E}-04$ \\
\hline COS & $5.710 \mathrm{E}-07$ & $4.913 \mathrm{E}-07$ & $5.010 \mathrm{E}-07$ & $4.554 \mathrm{E}-07$ \\
\hline $\mathrm{H}_{2} \mathrm{~S}$ & $1.142 \mathrm{E}-06$ & $9.826 \mathrm{E}-07$ & $1.002 \mathrm{E}-06$ & $9.108 \mathrm{E}-07$ \\
\hline $\mathrm{NH}_{3}$ & $0.000 \mathrm{E}+00$ & $0.000 \mathrm{E}+00$ & $0.000 \mathrm{E}+00$ & $0.000 \mathrm{E}+00$ \\
\hline $\mathrm{CO}_{2}$ & $1.252 \mathrm{E}-04$ & $1.077 \mathrm{E}-04$ & $1.098 \mathrm{E}-04$ & $9.982 \mathrm{E}-05$ \\
\hline $\mathbf{N}_{2}$ & $9.516 \mathrm{E}-07$ & $8.188 \mathrm{E}-07$ & $8.351 \mathrm{E}-07$ & $7.590 \mathrm{E}-07$ \\
\hline $\mathbf{O}_{2}$ & $0.000 \mathrm{E}+00$ & $0.000 \mathrm{E}+00$ & $0.000 \mathrm{E}+00$ & $0.000 \mathrm{E}+00$ \\
\hline Ar & $5.710 \mathrm{E}-07$ & $4.913 \mathrm{E}-07$ & $5.010 \mathrm{E}-07$ & $4.554 \mathrm{E}-07$ \\
\hline $\mathrm{Hg}$ & $4.023 \mathrm{E}-12$ & $3.461 \mathrm{E}-12$ & $3.530 \mathrm{E}-12$ & $3.208 \mathrm{E}-12$ \\
\hline \multirow[t]{2}{*}{$\mathrm{HCl}$} & $6.034 \mathrm{E}-08$ & 5.192E-08 & $5.295 \mathrm{E}-08$ & $4.813 \mathrm{E}-08$ \\
\hline & \multicolumn{3}{|l|}{$(5.3 .1)$} & (7.3.1) \\
\hline Support & $1.000 \mathrm{E}+00$ & 1.0 & $8+00$ & $1.000 \mathrm{E}+00$ \\
\hline Salt & $8.675 \mathrm{E}-02$ & 2.2 & E-02 & $1.770 \mathrm{E}-01$ \\
\hline $\mathrm{CO}$ & $3.768 \mathrm{E}-05$ & 3.4 & E-05 & $4.396 \mathrm{E}-05$ \\
\hline $\mathrm{CH}_{4}$ & $3.474 \mathrm{E}-05$ & 3.1 & E-05 & $4.054 \mathrm{E}-05$ \\
\hline $\mathbf{H}_{2}$ & $1.408 \mathrm{E}-04$ & 1.2 & $\bar{E}-04$ & $1.642 \mathrm{E}-04$ \\
\hline COS & $4.893 \mathrm{E}-07$ & & E-07 & $5.710 \mathrm{E}-07$ \\
\hline $\mathrm{H}_{2} \mathrm{~S}$ & $9.787 \mathrm{E}-07$ & & E-07 & $1.142 \mathrm{E}-06$ \\
\hline $\mathbf{N H}_{3}$ & $0.000 \mathrm{E}+00$ & 0.00 & $E+00$ & $0.000 \mathrm{E}+00$ \\
\hline $\mathrm{CO}_{2}$ & $1.073 \mathrm{E}-04$ & & $E-05$ & $1.252 \mathrm{E}-04$ \\
\hline $\mathbf{N}_{2}$ & $8.156 \mathrm{E}-07$ & 7.3 & E-07 & $9.516 \mathrm{E}-07$ \\
\hline $\mathbf{O}_{2}$ & $0.000 \mathrm{E}+00$ & 0.0 & $E+00$ & $0.000 \mathrm{E}+00$ \\
\hline $\mathbf{A r}$ & $4.893 \mathrm{E}-07$ & & E-07 & $5.710 \mathrm{E}-07$ \\
\hline $\mathrm{Hg}$ & $3.448 \mathrm{E}-12$ & 3.1 & $E-12$ & $4.023 \mathrm{E}-12$ \\
\hline $\mathbf{H C l}$ & $5.172 \mathrm{E}-08$ & 4.6 & E-08 & $6.034 \mathrm{E}-08$ \\
\hline
\end{tabular}


$\mathrm{H}_{2} \mathrm{~S}$ Mole Fraction vs Temperature for a Lurgi Gasifier Off-Gas and a "Non-Reactive" Support with various High Temperature Salts under Reducing Conditions

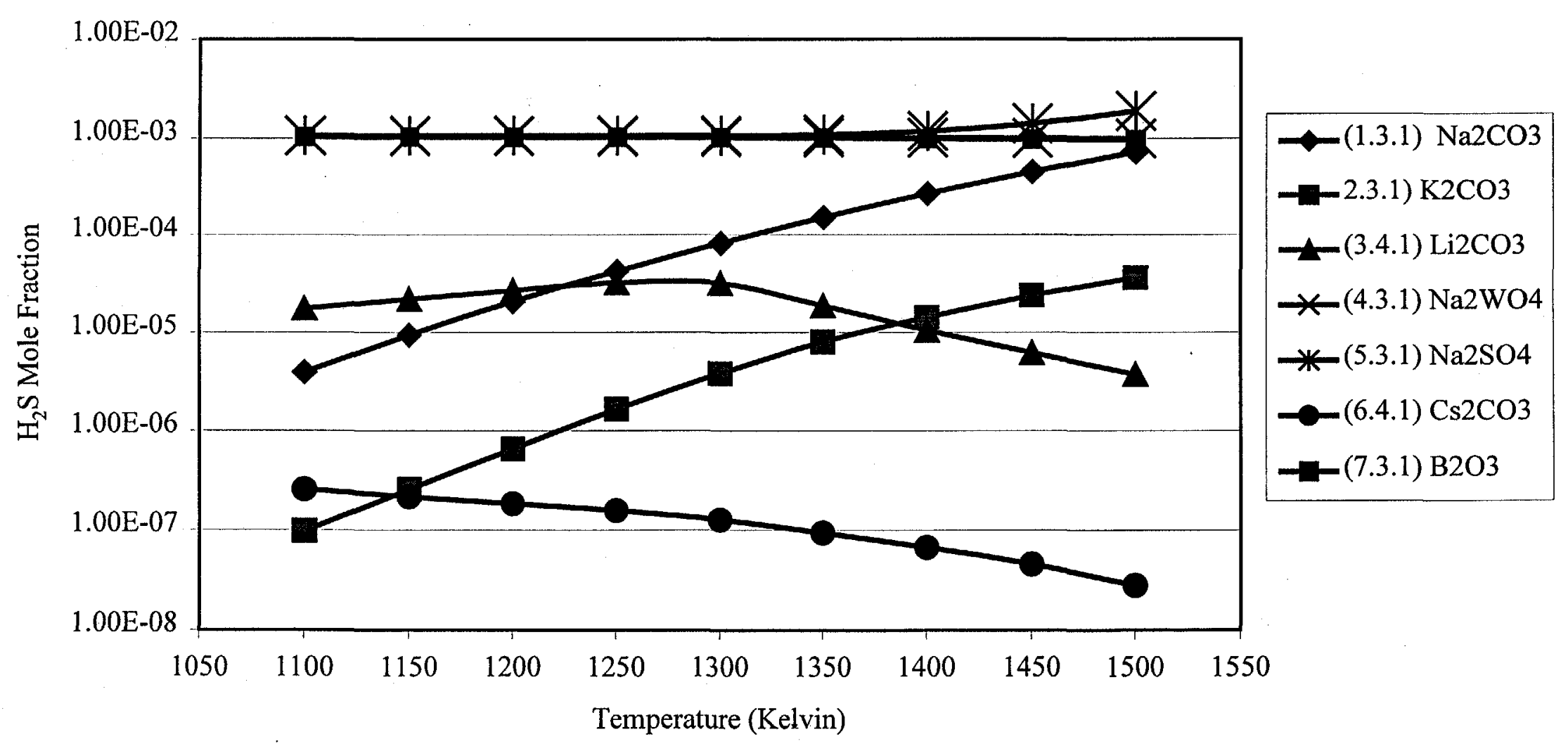

Figure A.20 $\mathrm{H}_{2} \mathrm{~S}$ Mole Fraction for a Lurgi Gasifier Off-Gas and a "Non-Reactive" Support with various High Temperature Salts under Reducing Conditions. 
$\mathrm{SO}_{2}$ Mole Fraction vs Temperature for a Lurgi Gasifier Off-Gas and a "Non-Reactive" Support with various High Temperature Salts under Reducing Conditions

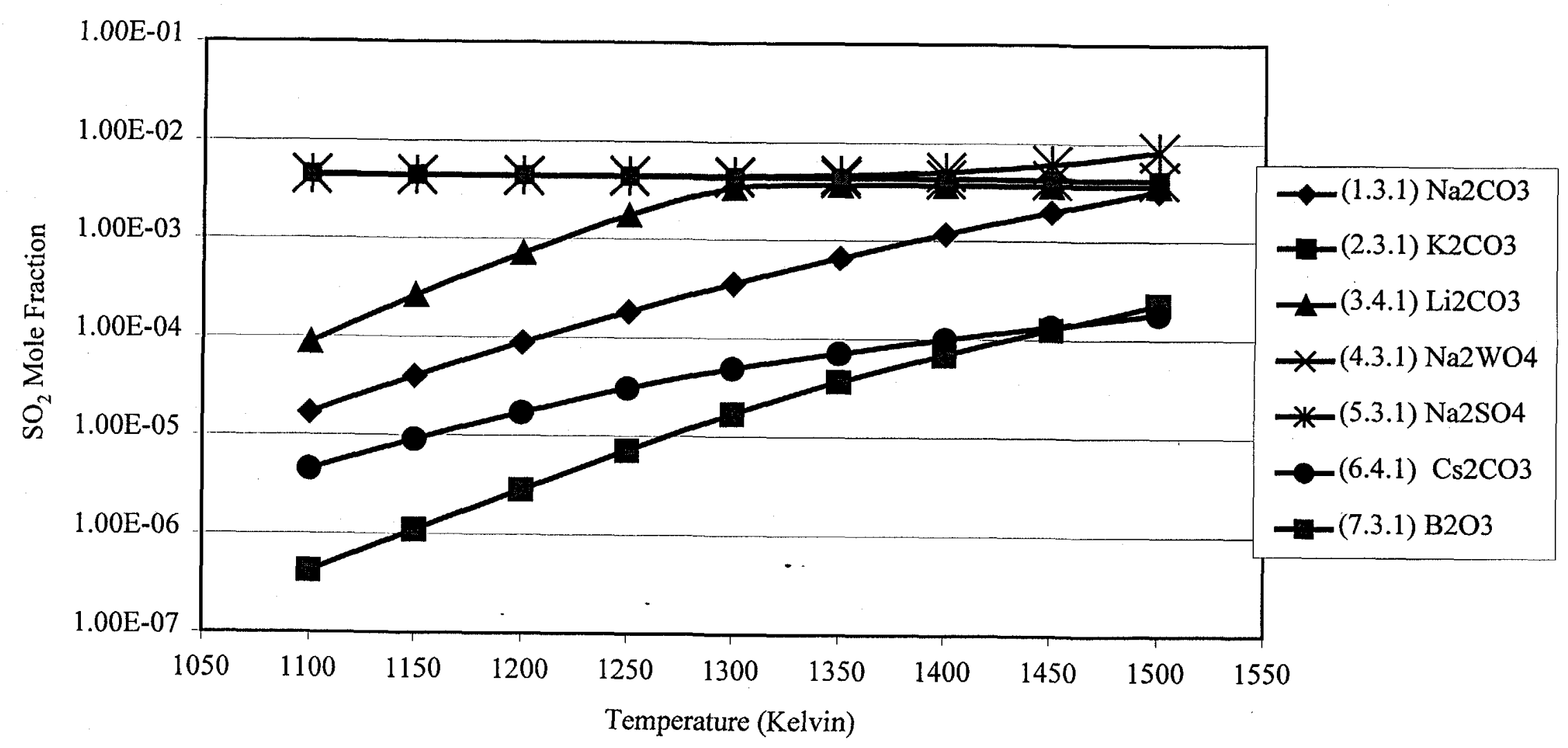

Figure A.21 $\mathrm{SO}_{2}$ Mole Fraction for a Lurgi Gasifier Off-Gas and a "Non-Reactive" Support with various High Temperature Salts under Reducing Conditions. 
Significant Gaseous Species Mole Fraction vs Temperature for $\mathrm{K}_{2} \mathrm{CO}_{3}$ and a Lurgi Off-Gas with $\mathrm{ZrO}_{2}$ under Reducing Conditions (2.3.1)

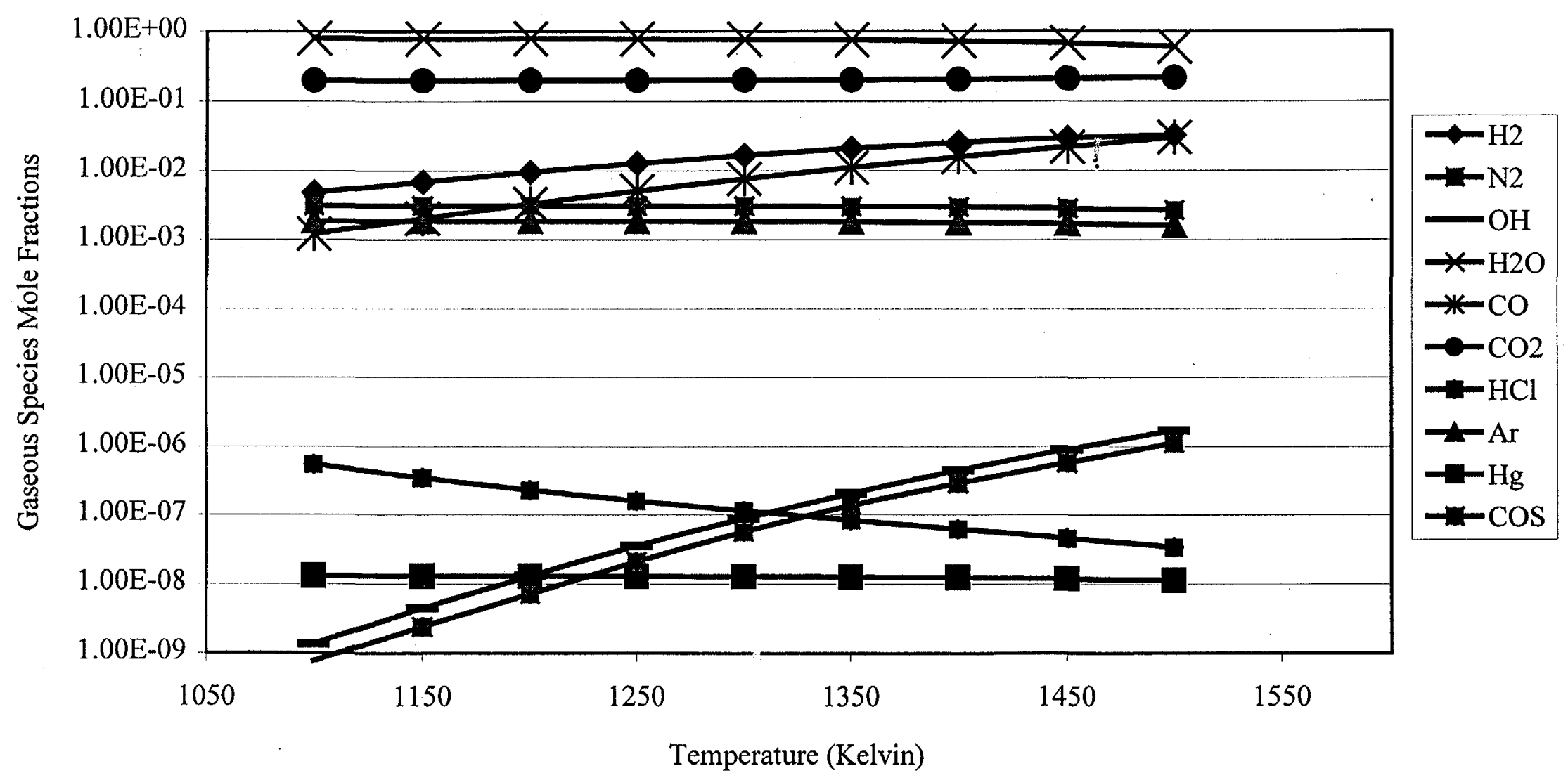

Figure A.22 Significant Gaseous Species Mole Fraction vs Temperature for $\mathrm{K}_{2} \mathrm{CO}_{3}$ and Lurgi Off-Gas with $\mathrm{ZrO}_{2}$ under Reducing Conditions (2.3.1). 
Potassium Gaseous Species vs Temperature for $\mathrm{K}_{2} \mathrm{CO}_{3}$ and a Lurgi Off-Gas with $\mathrm{ZrO}_{2}$ under Reducing Conditions (2.3.1)

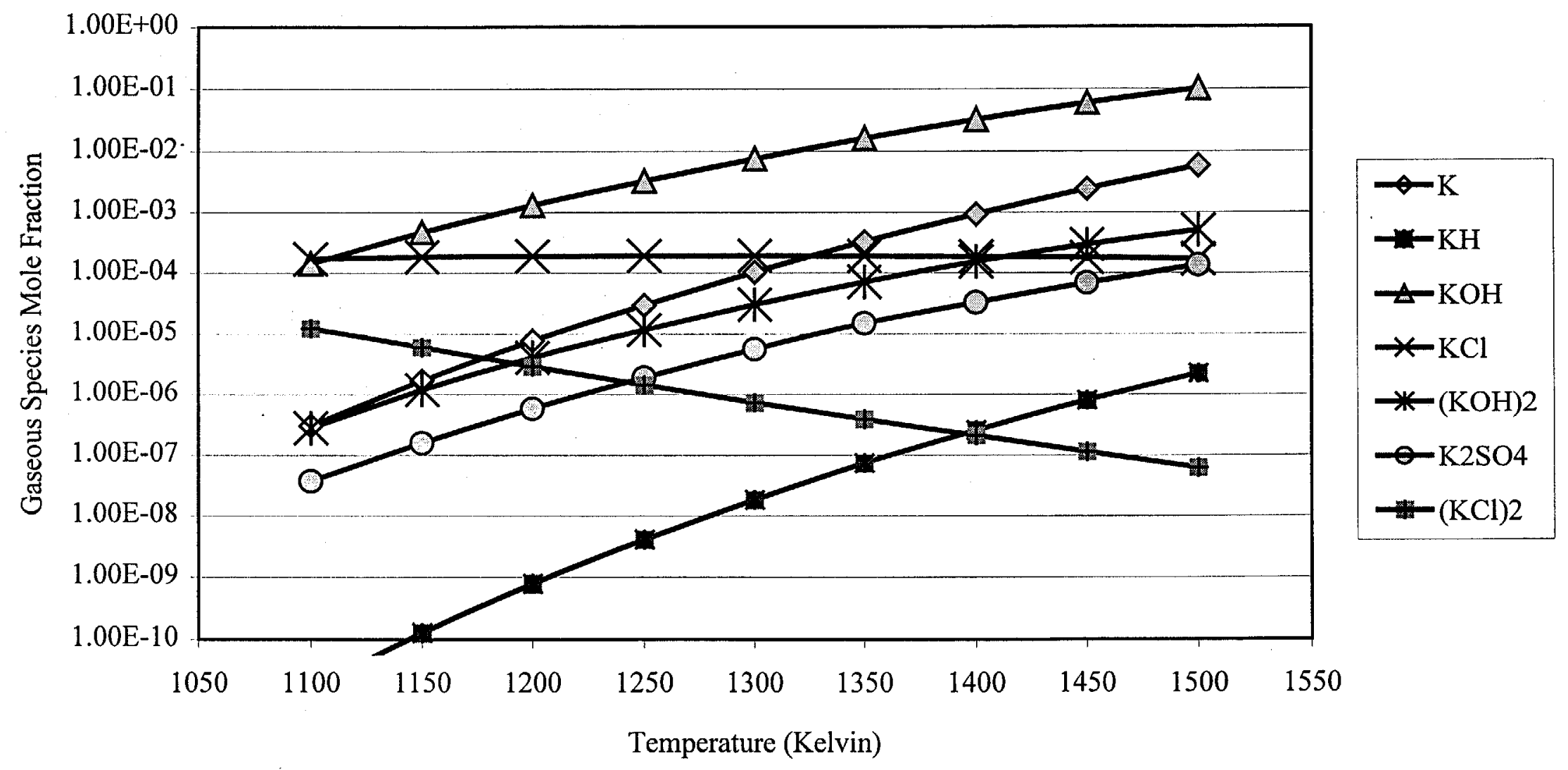

Figure A.23 Potassium Gaseous Species Mole Fractions for $\mathrm{K}_{2} \mathrm{CO}_{3}$ and a Lurgi Off-Gas with $\mathrm{ZrO}_{2}$ under Reducing Conditions (2.3.1). 
$\mathrm{H}_{2} \mathrm{~S}$ Mole Fraction vs Temperature for $\mathrm{K}_{2} \mathrm{CO}_{3}$ and a Lurgi Gasifier Off-Gas with various "Non-Reactive" Supports under Reducing Condtions

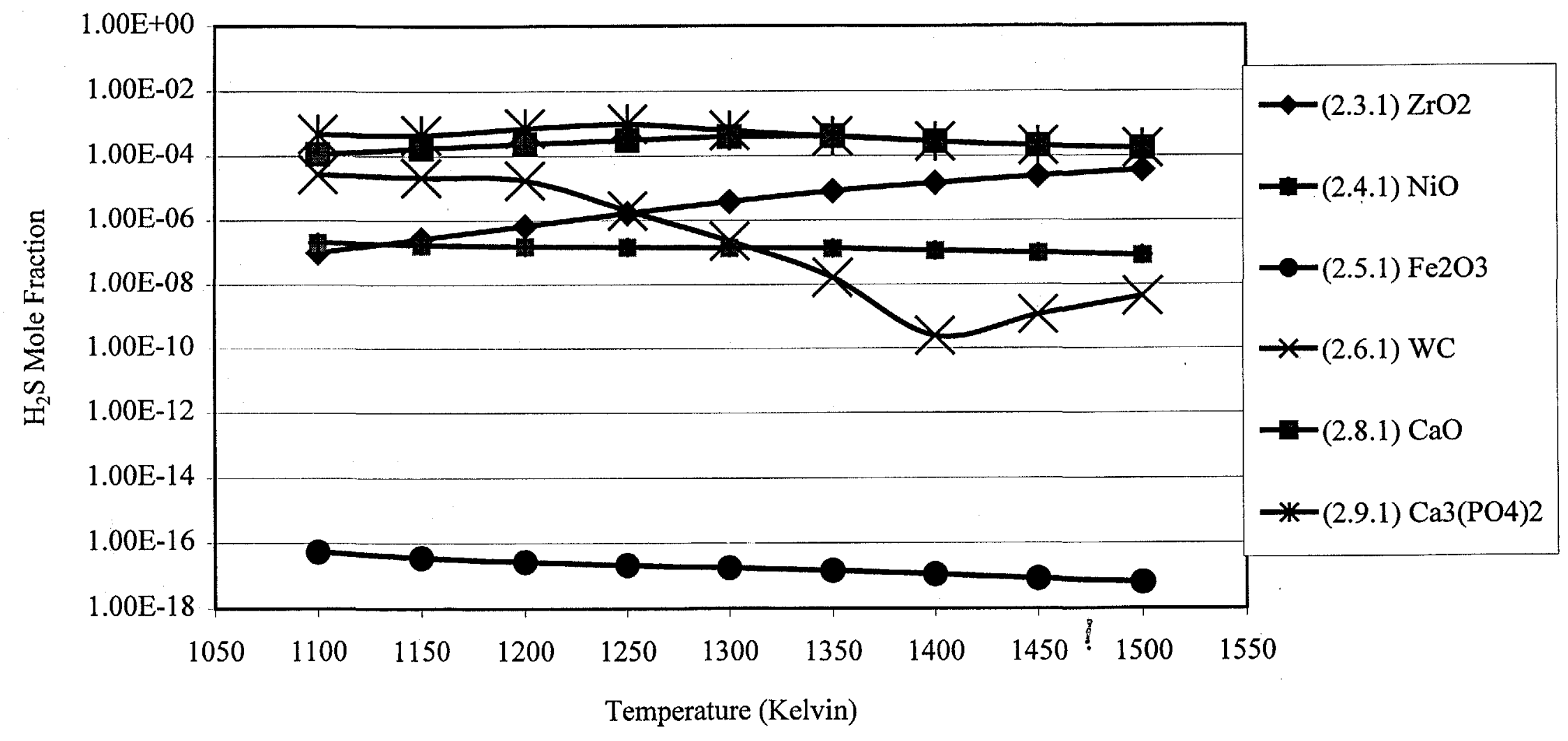

Figure A.24 $\mathrm{H}_{2} \mathrm{~S}$ Mole Fraction for $\mathrm{K}_{2} \mathrm{CO}_{3}$ and a Lurgi Gasifier Off-Gas with various "Non-Reactive" Supports under Reducing Conditions. 
$\mathrm{SO}_{2}$ Mole Fraction vs Temperature for $\mathrm{K}_{2} \mathrm{CO}_{3}$ and a Lurigi Off-Gas with various Supports under Reducing Conditions

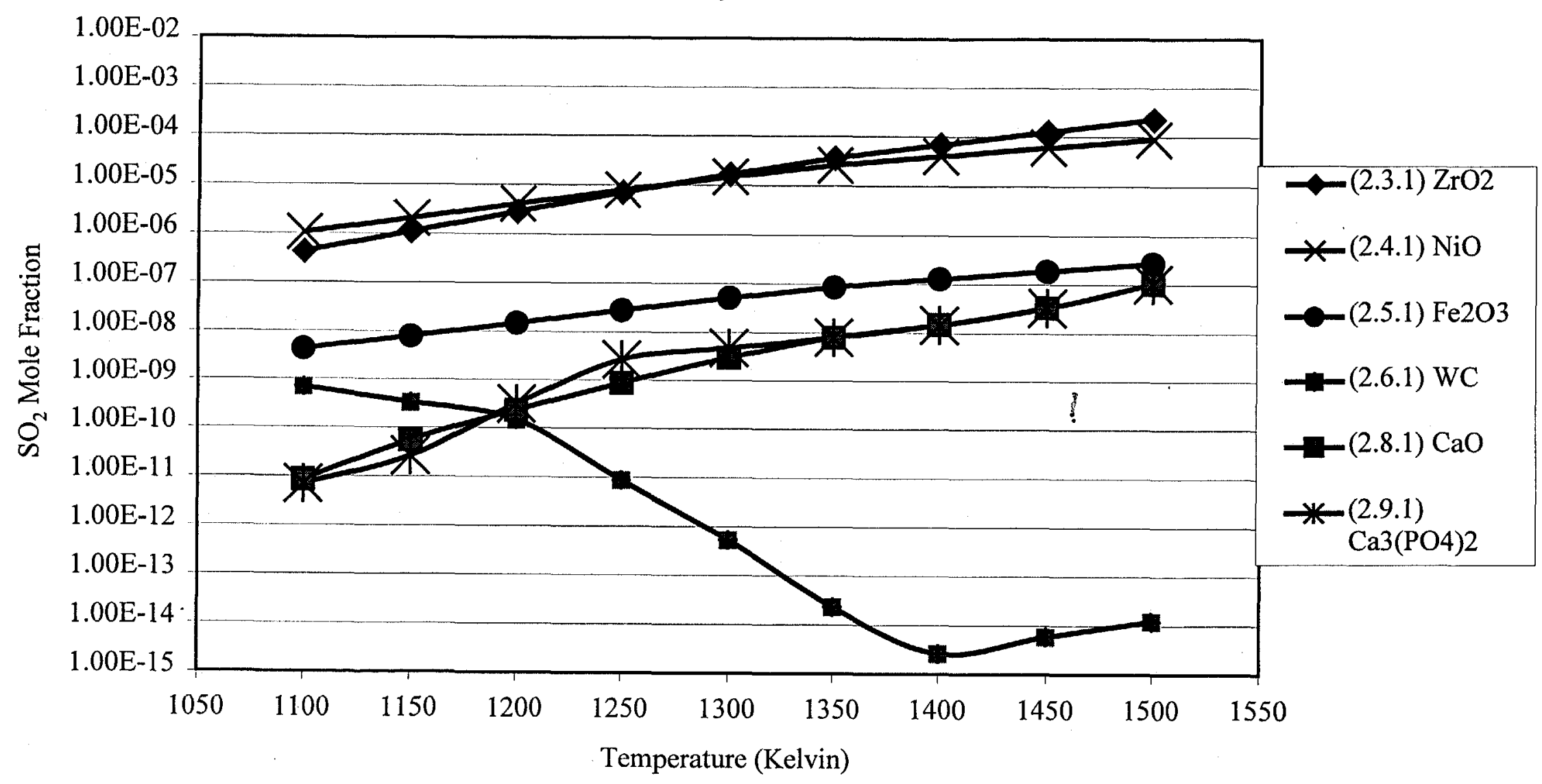

Figure A.25 $\mathrm{SO}_{2}$ Mole Fraction for $\mathrm{K}_{2} \mathrm{CO}_{3}$ and a Lurgi Off-Gas with "Non-Reactive" Supports under Reducing Conditions. 
Figures A.24 and A.25 show $\mathrm{H}_{2} \mathrm{~S}$ and $\mathrm{SO}_{2}$ concentrations, respectively, for systems with $\mathrm{K}_{2} \mathrm{CO}_{3}$ supported on what were thought to be "non-reactive" supports. The entering molar ratios for the equilibrium simulations are listed in Table A.10. Surprisingly, the degree of sulfur capture is a function of the type of support used. The system with $\mathrm{Fe}_{2} \mathrm{O}_{3}$ by far does the best in terms of sulfur capture with extremely low concentrations of $\mathrm{H}_{2} \mathrm{~S}$ and $\mathrm{SO}_{2}$ below the ppm-v level over the entire temperature range explored

In these systems, again two distinct types of behavior are seen. $\mathrm{ZrO}_{2}, \mathrm{NiO}$, and $\mathrm{Fe}_{2} \mathrm{O}_{3}$ all partially react, releasing oxygen to the system. This causes these systems to behave as if they were under weakly oxidized conditions, which accounts for the significant concentrations of $\mathrm{SO}_{2}$ seen in Figure A.25. The presence of oxygen also accounts for the low concentrations of $\mathrm{H}_{2}$ and $\mathrm{CO}$ and high concentrations of $\mathrm{CO}_{2}$ and water vapor present for these three systems seen in Figures A.23, A.26 and A.27. Under these weak oxidizing conditions, the sulfur was captured as $\mathrm{K}_{2} \mathrm{SO}_{4}$. The amount of sulfur captured in these three systems is highest for the iron oxide support. Unfortunately, this system also has $\mathrm{H}_{2}$ and $\mathrm{CO}$ concentrations two orders of magnitude lower than the either $\mathrm{NiO}$ or $\mathrm{ZrO}_{2}$.

For $\mathrm{WC}, \mathrm{CaO}$, and $\mathrm{Ca}_{3}\left(\mathrm{PO}_{4}\right)_{2}$, the situation was entirely different. These three systems behaved like they were under reducing conditions. Their respective $\mathrm{SO}_{2}$ concentrations were all very low, but their $\mathrm{H}_{2} \mathrm{~S}$ concentrations were much higher, which indicates a reduced environment. For these three supports, the sulfur captured was in a reduced form, like $\mathrm{K}_{2} \mathrm{~S}$ or CaS. Figures A.28-30 show the main gaseous constituents as $\mathrm{H}_{2}$ and $\mathrm{CO}$ for all three systems, opposed to $\mathrm{CO}_{2}$ and $\mathrm{H}_{2} \mathrm{O}$ like the previous supports. An important note regarding the WC system; around $1350 \mathrm{~K}$ the remaining $\mathrm{K}_{2} \mathrm{CO}_{3}$ dissociates diluting the gas phase, which causes the sudden drop in gaseous species concentrations. Another important aspect of the reduced system is the high concentrations of COS still present in the systems seen Figure A.28-A.30. For WC from $1100-1200 \mathrm{~K}$ there is a COS concentration on the order of $100 \mathrm{ppm}-\mathrm{v}$, which explains where the sulfur resides. The other two reducing supports $(\mathrm{CaO}$ and $\left.\mathrm{Ca}_{3}\left(\mathrm{PO}_{4}\right)_{2}\right)$ have $\mathrm{COS}$ concentrations an order of magnitude lower than the WC system over the entire temperature range.

The amount of gaseous potassium species follows the same temperature trend seen for the high temperature oxidizing section. Figure A.31-A.33 show that the potassium gaseous species are essentially the same for the "oxidizing" supports. Figures A.34-A.36 show that the potassium gaseous species are the same for the "reducing" supports up until the point where $\mathrm{K}_{2} \mathrm{CO}_{3}$ breaks down in the WC system. The primary difference between the two groups of support gaseous species' concentrations is the presence of $\mathrm{K}_{2} \mathrm{SO}_{4}$ (g) in the "oxidized" systems and higher $\mathrm{K}$ (g) concentrations in the "reduced" systems.

Equilibrium shows that not one of the supports investigated is truly stable under reduced conditions at high temperature. The supports do not necessarily react with the salt as seen in the high temperature oxidizing environment, but do react to a small extent. It is entirely possible for a system such as (2.4.1), with $\mathrm{NiO}$ as the 
support, that the reaction that forms the small amount $\mathrm{Ni}$ (s) seen in the equilibrium products is kinetically limited. If it was kinetically limited, the support would be nonreactive and the system as a whole should behave as if under reduced conditions. Even if this scenario was possible the sulfur capture seen in the other "reduced" systems was not to the extent to warrant using the high temperature fluidized bed as a gas clean up system for carbonate fuel cells. The $\mathrm{H}_{2} \mathrm{~S}$ concentrations are around 100 $\mathrm{ppm}-\mathrm{v}$ at the lower temperatures for the three reducing supports, which are one to two orders of magnitude higher than acceptable levels for a fuel cell system. In the end, the high temperature region under reducing conditions does not possess sufficient sulfur or mercury capturing capability to justify its implementation. 
Table A.10 FACT entering Molar Ratios for $\mathrm{K}_{2} \mathrm{CO}_{3}$ and a Lurgi Off-Gas with various Supports under Reducing Conditions.

\begin{tabular}{|c|c|c|c|c|}
\hline & (2.1.1) & (2.2.1) & $(2.4 .1)$ & $\overline{(2.5 .1)}$ \\
\hline Support & $1.000 \mathrm{E}+00$ & $1.000 \mathrm{E}+00$ & $1.000 \mathrm{E}+00$ & $1.000 \mathrm{E}+00$ \\
\hline Salt & $4.347 \mathrm{E}-02$ & $7.378 \mathrm{E}-02$ & $5.404 \mathrm{E}-02$ & $1.155 \mathrm{E}-01$ \\
\hline $\mathrm{CO}$ & $3.515 \mathrm{E}-05$ & $3.689 \mathrm{E}-05$ & $3.574 \mathrm{E}-05$ & $3.952 \mathrm{E}-05$ \\
\hline $\mathrm{CH}_{4}$ & 3.241E-05 & $3.402 \mathrm{E}-05$ & $3.296 \mathrm{E}-05$ & $3.644 \mathrm{E}-05$ \\
\hline$\overline{\mathbf{H}_{2}}$ & $1.313 \mathrm{E}-04$ & $1.378 \mathrm{E}-04$ & $1.335 \mathrm{E}-04$ & $1.477 \mathrm{E}-04$ \\
\hline $\mathrm{COS}$ & $4.565 \mathrm{E}-07$ & 4.791E-07 & 4.642E-07 & $5.133 \mathrm{E}-07$ \\
\hline $\mathrm{H}_{2} \mathrm{~S}$ & $9.130 \mathrm{E}-07$ & $9.582 \mathrm{E}-07$ & $9.284 \mathrm{E}-07$ & $1.027 \mathrm{E}-06$ \\
\hline $\mathbf{N H}_{3}$ & $0.000 \mathrm{E}+00$ & $0.000 \mathrm{E}+00$ & $0.000 \mathrm{E}+00$ & $0.000 \mathrm{E}+00$ \\
\hline $\mathrm{CO}_{2}$ & $1.001 \mathrm{E}-04$ & $1.050 \mathrm{E}-04$ & $1.017 \mathrm{E}-04$ & $1.125 \mathrm{E}-04$ \\
\hline $\mathbf{N}_{2}$ & $7.608 \mathrm{E}-07$ & $7.985 \mathrm{E}-07$ & $7.736 \mathrm{E}-07$ & $8.555 \mathrm{E}-07$ \\
\hline $\mathbf{O}_{2}$ & $0.000 \mathrm{E}+00$ & $0.000 \mathrm{E}+00$ & $0.000 \mathrm{E}+00$ & $0.000 \mathrm{E}+00$ \\
\hline Ar & $4.565 \mathrm{E}-07$ & $4.791 \mathrm{E}-07$ & $4.642 \mathrm{E}-07$ & $5.133 \mathrm{E}-07$ \\
\hline $\mathbf{H g}$ & $3.216 \mathrm{E}-12$ & $3.376 \mathrm{E}-12$ & $3.270 \mathrm{E}-12$ & $3.616 \mathrm{E}-12$ \\
\hline $\mathbf{H C l}$ & $4.824 \mathrm{E}-08$ & $5.063 \mathrm{E}-08$ & $4.906 \mathrm{E}-08$ & $5.425 \mathrm{E}-08$ \\
\hline & (2.6.1) & $(2.7 .1)$ & (2.8.1) & (2.9.1) \\
\hline Support & $1.000 \mathrm{E}+00$ & $1.000 \mathrm{E}+00$ & $1.000 \mathrm{E}+00$ & $1.000 \mathrm{E}+00$ \\
\hline Salt & $1.417 \mathrm{E}-01$ & $5.780 \mathrm{E}-02$ & $4.057 \mathrm{E}-02$ & $2.244 \mathrm{E}-01$ \\
\hline $\mathrm{CO}$ & $4.133 \mathrm{E}-05$ & $3.596 \mathrm{E}-05$ & $3.499 \mathrm{E}-05$ & $4.795 \mathrm{E}-05$ \\
\hline $\mathrm{CH}_{4}$ & $3.811 \mathrm{E}-05$ & $3.315 \mathrm{E}-05$ & $3.226 \mathrm{E}-05$ & $4.422 \mathrm{E}-05$ \\
\hline $\mathrm{H}_{2}$ & $1.544 \mathrm{E}-04$ & $1.343 \mathrm{E}-04$ & $1.307 \mathrm{E}-04$ & $1.791 \mathrm{E}-04$ \\
\hline $\mathrm{COS}$ & $5.367 \mathrm{E}-07$ & $4.670 \mathrm{E}-07$ & $4.544 \mathrm{E}-07$ & $6.227 \mathrm{E}-07$ \\
\hline$\overline{\mathrm{H}_{2} \mathrm{~S}}$ & $1.073 \mathrm{E}-06$ & $9.339 \mathrm{E}-07$ & $9.088 \mathrm{E}-07$ & $1.245 \mathrm{E}-06$ \\
\hline $\mathrm{NH}_{3}$ & $0.000 \mathrm{E}+00$ & $0.000 \mathrm{E}+00$ & $0.000 \mathrm{E}+00$ & $0.000 \mathrm{E}+00$ \\
\hline $\mathrm{CO}_{2}$ & $1.176 \mathrm{E}-04$ & $1.024 \mathrm{E}-04$ & $9.961 \mathrm{E}-05$ & $1.365 \mathrm{E}-04$ \\
\hline $\mathbf{N _ { 2 }}$ & $8.945 \mathrm{E}-07$ & $7.783 \mathrm{E}-07$ & $7.573 \mathrm{E}-07$ & $1.038 \mathrm{E}-06$ \\
\hline$\overline{\mathbf{O}_{2}}$ & $0.000 \mathrm{E}+00$ & $0.000 \mathrm{E}+00$ & $0.000 \mathrm{E}+00$ & $0.000 \mathrm{E}+00$ \\
\hline $\mathbf{A r}$ & $5.367 \mathrm{E}-07$ & $4.670 \mathrm{E}-07$ & $4.544 \mathrm{E}-07$ & $6.227 \mathrm{E}-07$ \\
\hline $\mathbf{H g}$ & $3.781 \mathrm{E}-12$ & $3.290 \mathrm{E}-12$ & $3.201 \mathrm{E}-12$ & $4.388 \mathrm{E}-12$ \\
\hline $\mathrm{HCl}$ & $5.672 \bar{E}-08$ & $4.935 \mathrm{E}-08$ & $4.802 \mathrm{E}-08$ & $6.581 \mathrm{E}-08$ \\
\hline
\end{tabular}


Significant Gaseous Species Mole Fraction vs Temperature for $\mathrm{K}_{2} \mathrm{CO}_{3}$ and a Lurgi Off-Gas with NiO under Reducing Conditions (2.4.1)

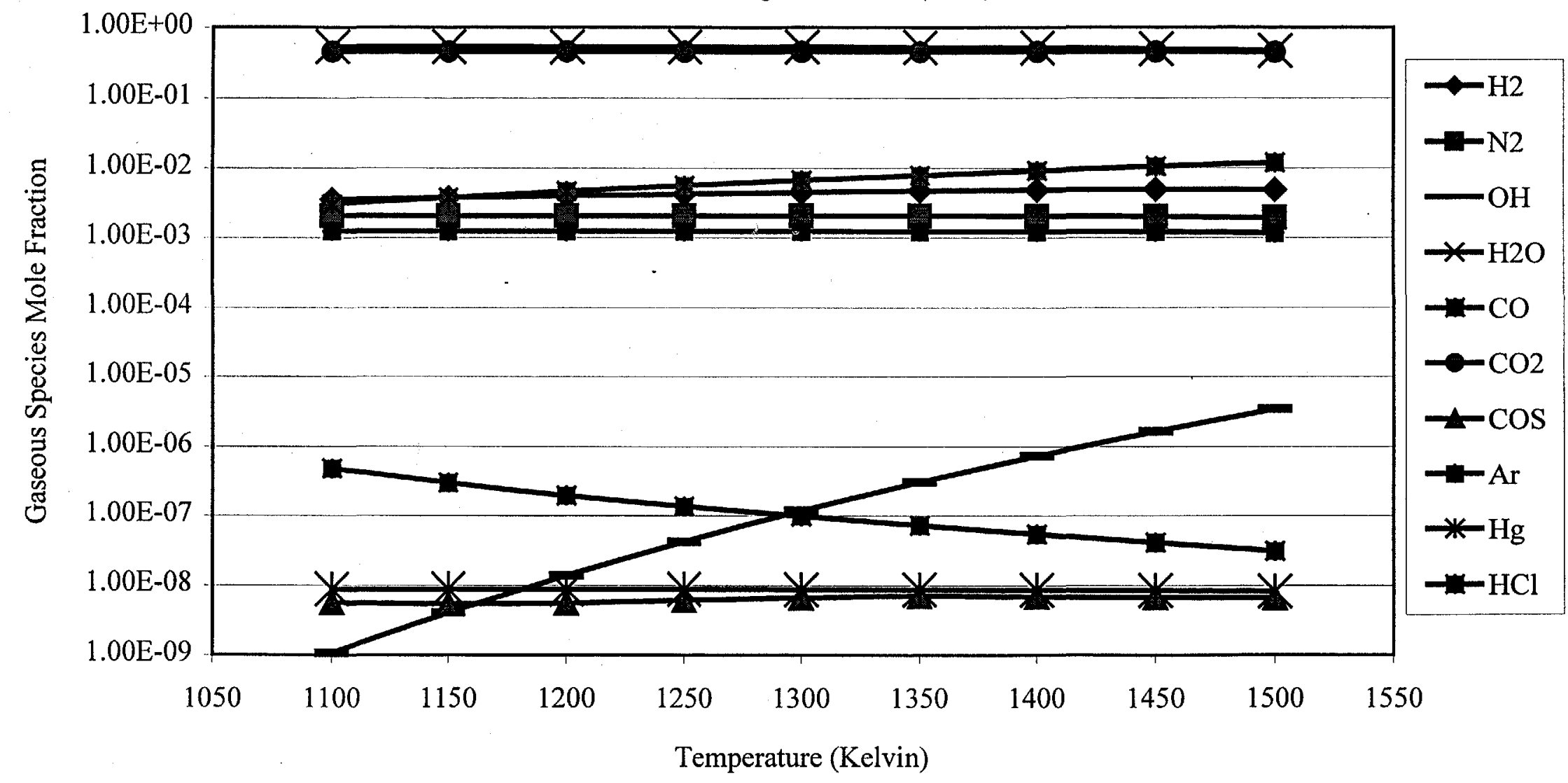

Figure A.26 Significant Gaseous Species Mole Fraction for $\mathrm{K}_{2} \mathrm{CO}_{3}$ and a Lurgi Off-Gas with NiO under Reducing Conditions (2.4.1). 
Significant Gaseous Species Mole Fraction vs Temperature for $\mathrm{K}_{2} \mathrm{CO}_{3}$ and a Lurgi Off-Gas with $\mathrm{Fe}_{2} \mathrm{O}_{3}$ under Reducing Conditions (2.5.1)

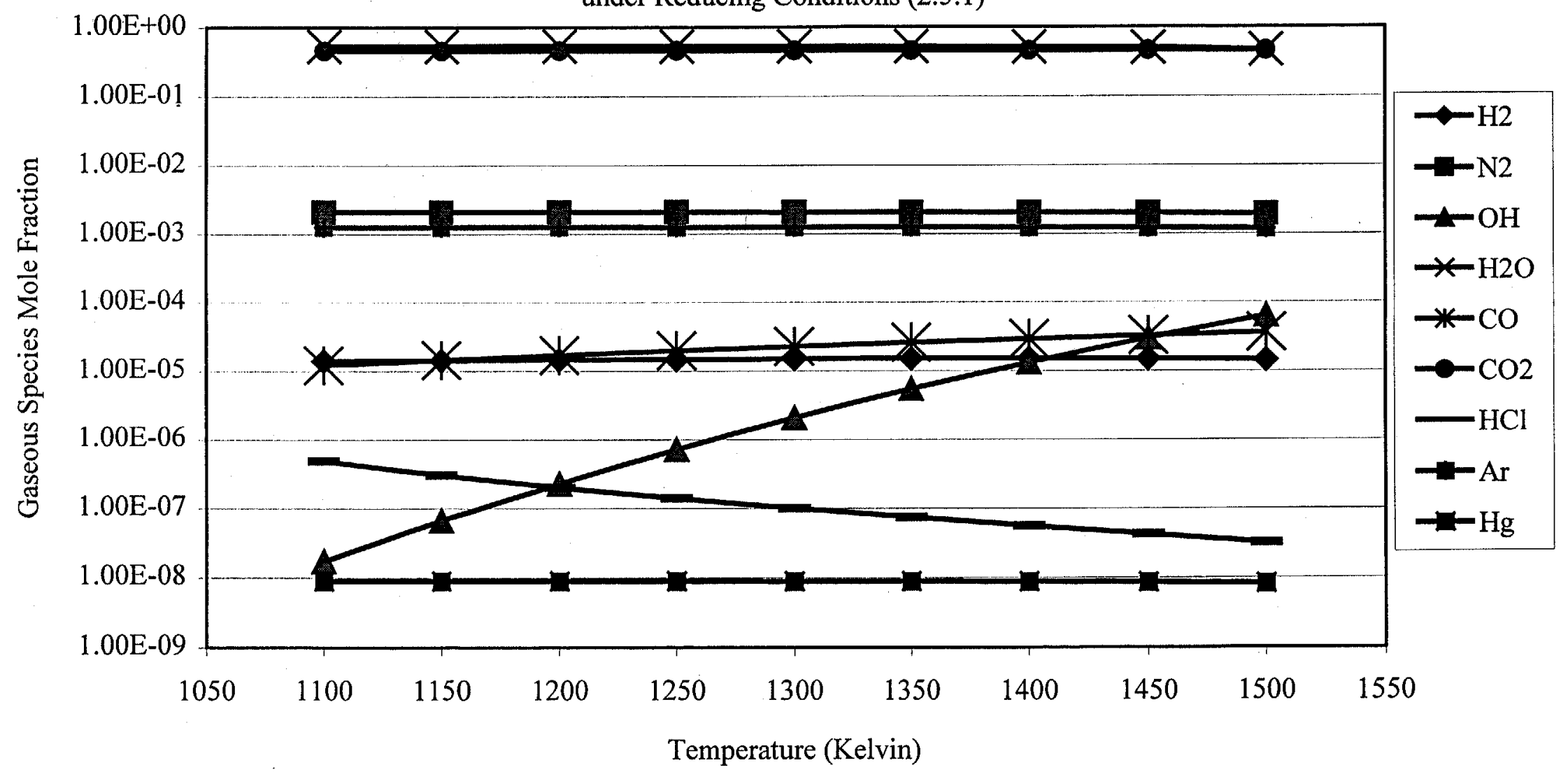

Figure A.27 Significant Gaseous Species Mole Fraction for $\mathrm{K}_{2} \mathrm{CO}_{3}$ and a Lurgi Off-Gas with $\mathrm{Fe}_{2} \mathrm{O}_{3}$ under Reducing Conditions (2.5.1). 


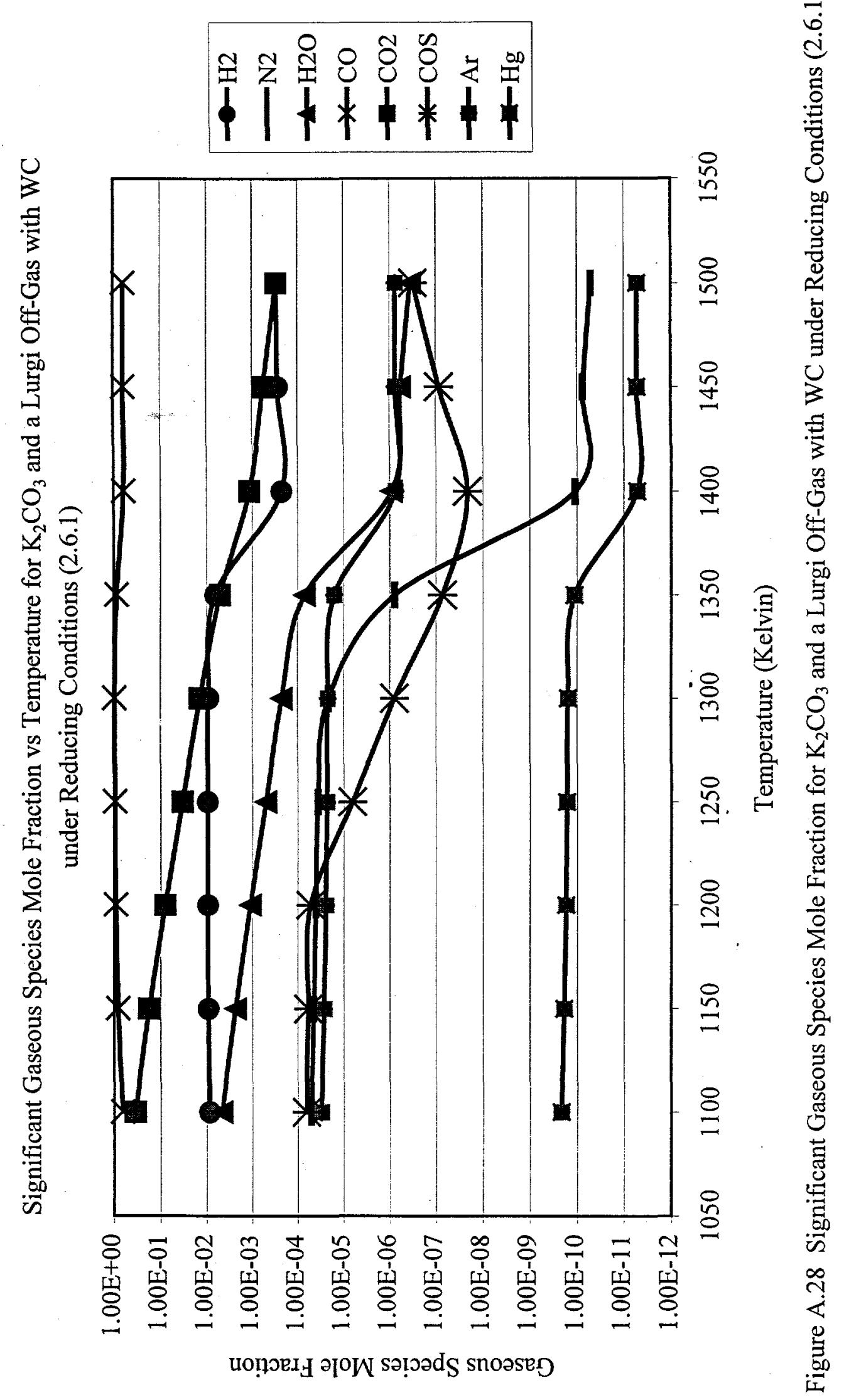




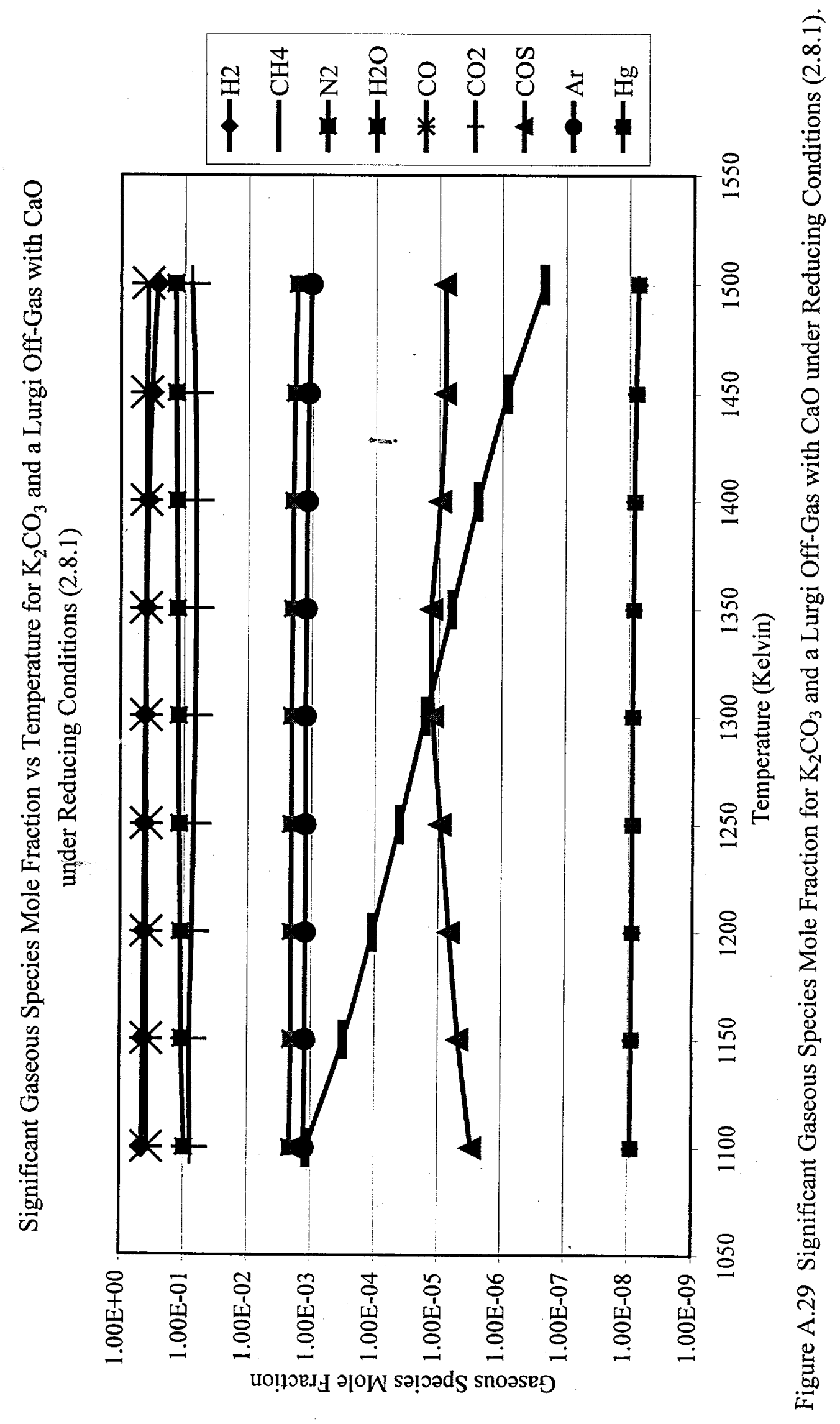


Significant Gaseous Species Mole Fraction for $\mathrm{K}_{2} \mathrm{CO}_{3}$ and a Lurgi Off-Gas with $\mathrm{Ca}_{3}\left(\mathrm{PO}_{4}\right)_{2}$ under Reducing Conditions (2.9.1)

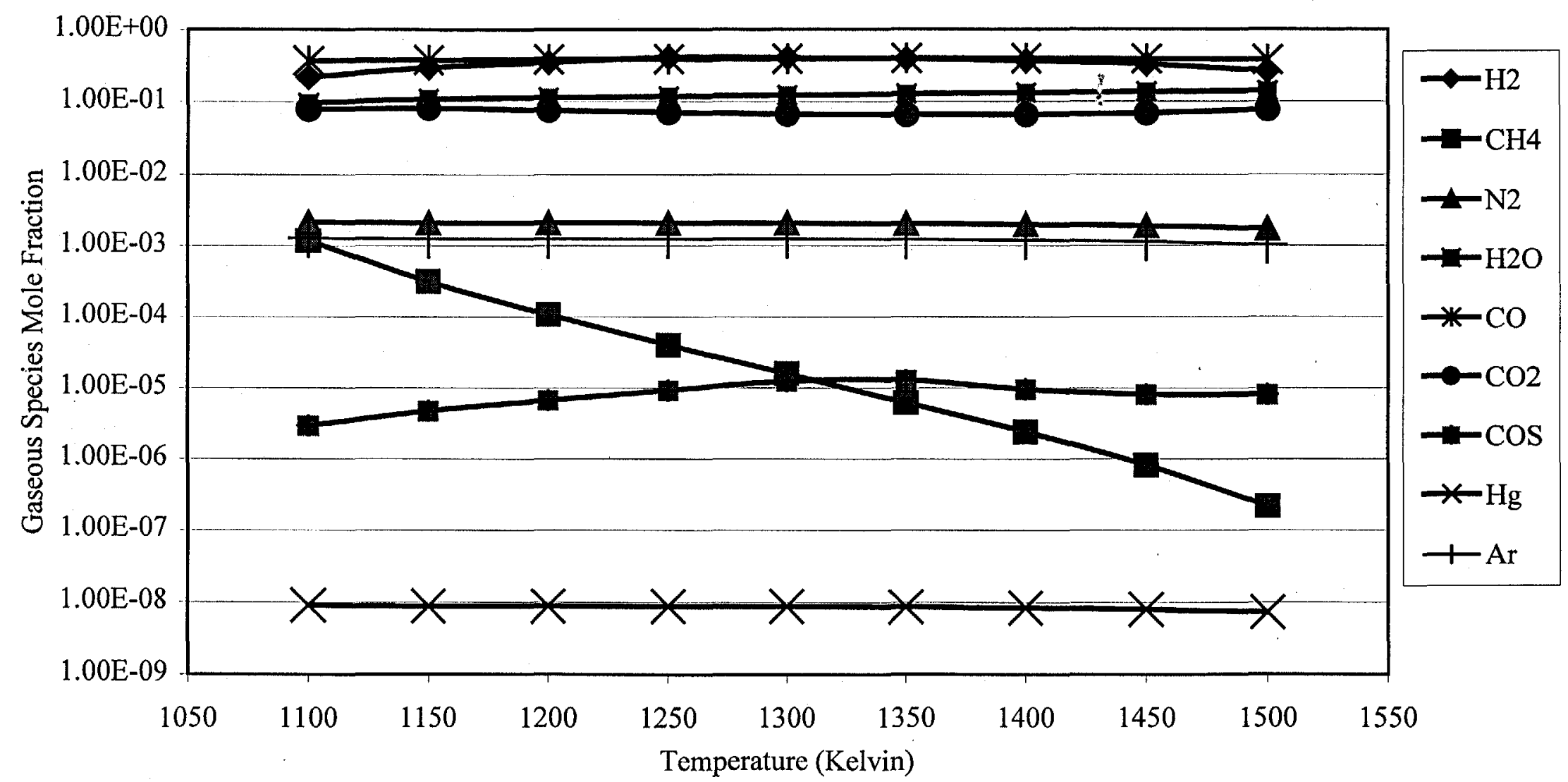

Figure A.30 Significant Gaseous Species Mole Fraction for $\mathrm{K}_{2} \mathrm{CO}_{3}$ and a Lurgi Off-Gas with $\mathrm{Ca}_{3}\left(\mathrm{PO}_{4}\right)_{2}$ under Reducing Conditions (2.9.1). 
Potassium Gaseous Species Mole Fraction vs Temperature for $\mathrm{K}_{2} \mathrm{CO}_{3}$ and a Lurgi Off-Gas with NiO under Reducing Conditions (2.4.1)

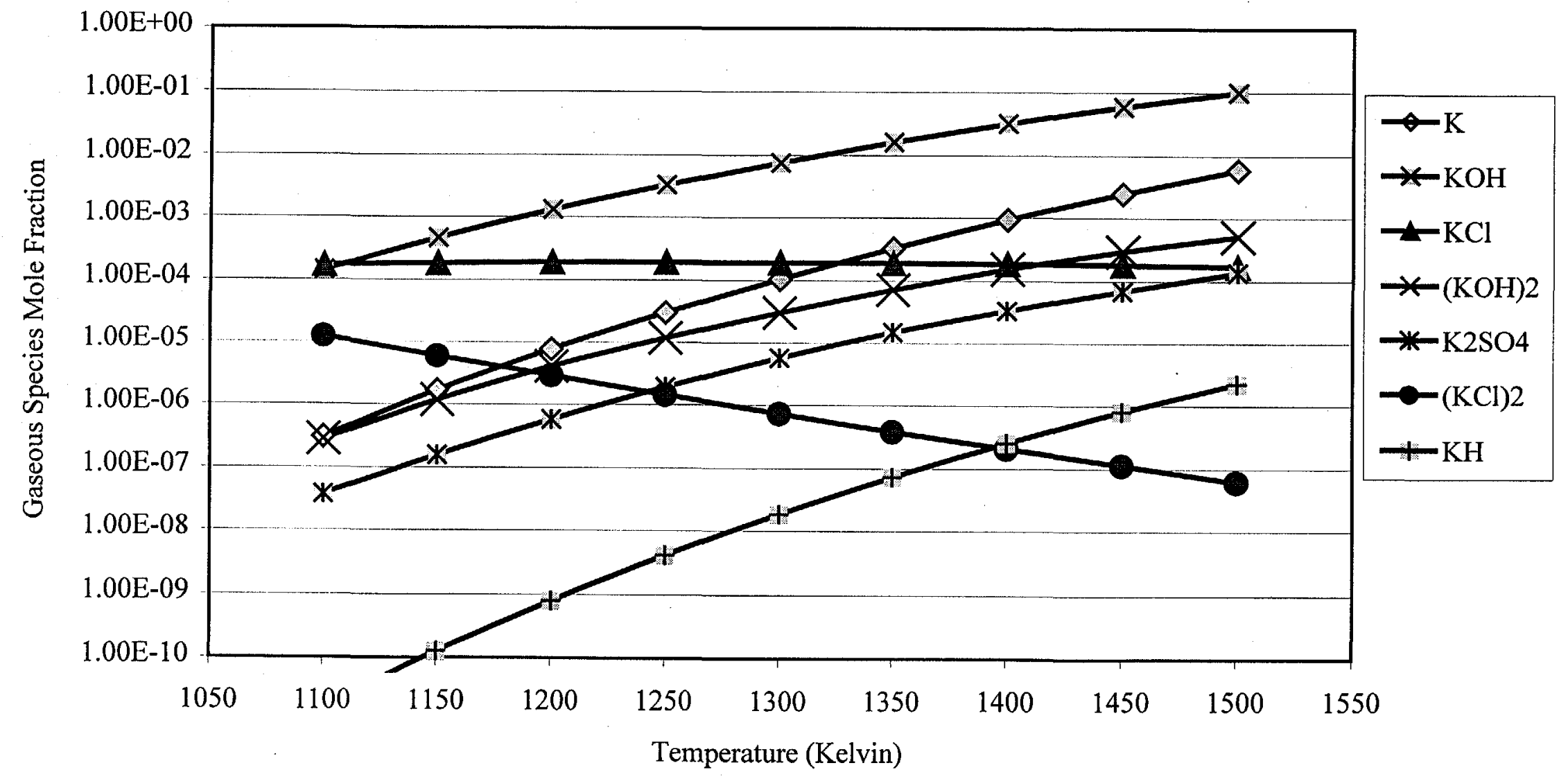

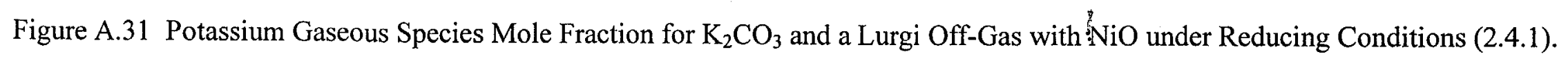


Potassium Gaseous Species Mole Fraction vs Temperature for $\mathrm{K}_{2} \mathrm{CO}_{3}$ and a Lurgi Off-Gas with $\mathrm{Fe}_{2} \mathrm{O}_{3}$ under Reducing Conditions (2.5.1)

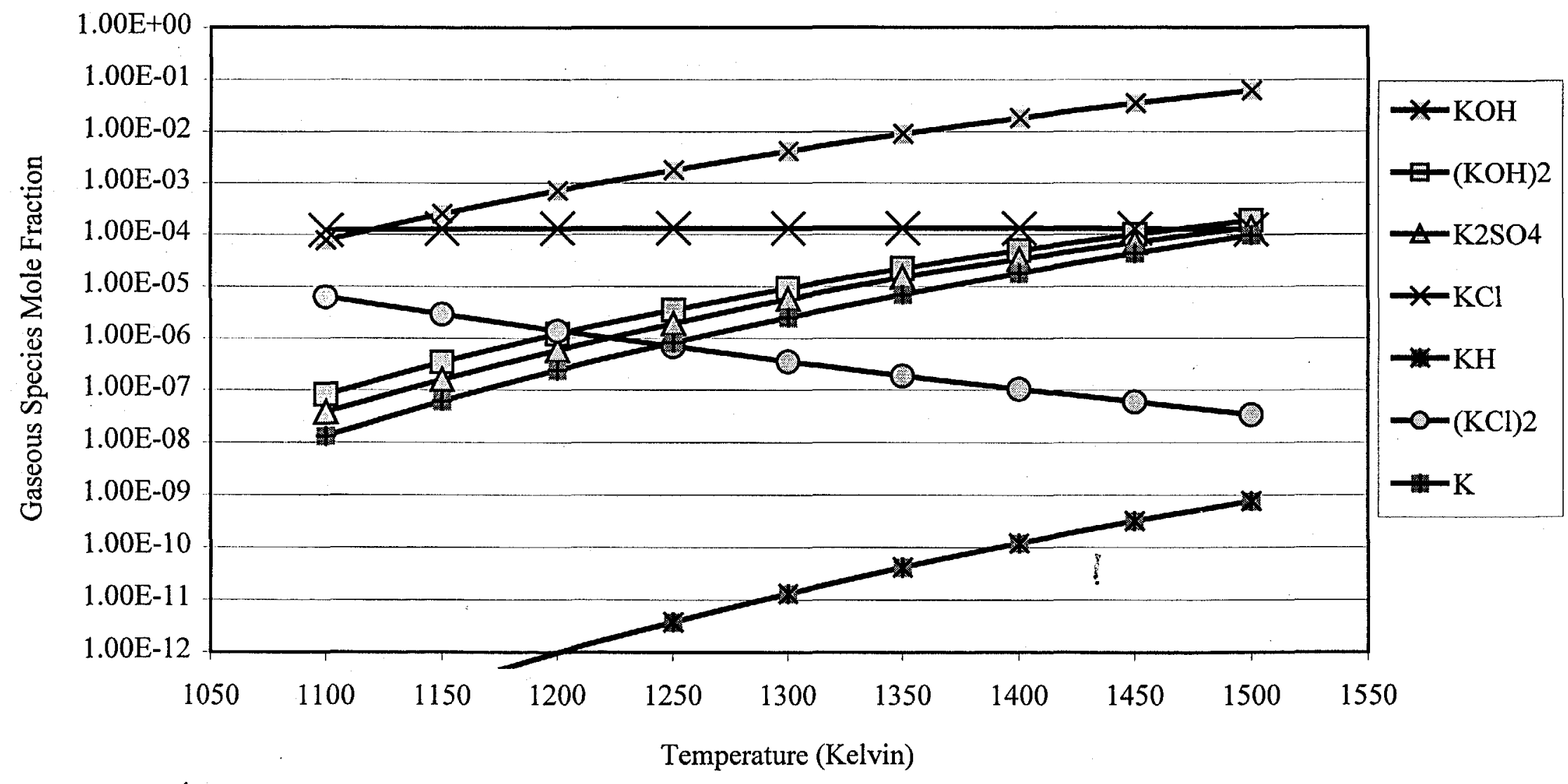

Figure A.32 Potassium Gaseous Species Mole Fraction for $\mathrm{K}_{2} \mathrm{CO}_{3}$ and a Lurgi Off-Gas with $\mathrm{Fe}_{2} \mathrm{O}_{3}$ under Reducing Conditions $(2.5 .1)$. 
Potassium Gaseous Species Mole Fraction vs Temperature for $\mathrm{K}_{2} \mathrm{CO}_{3}$ and a Lurgi Off-Gas with WC under Reducing Conditions (2.6.1)

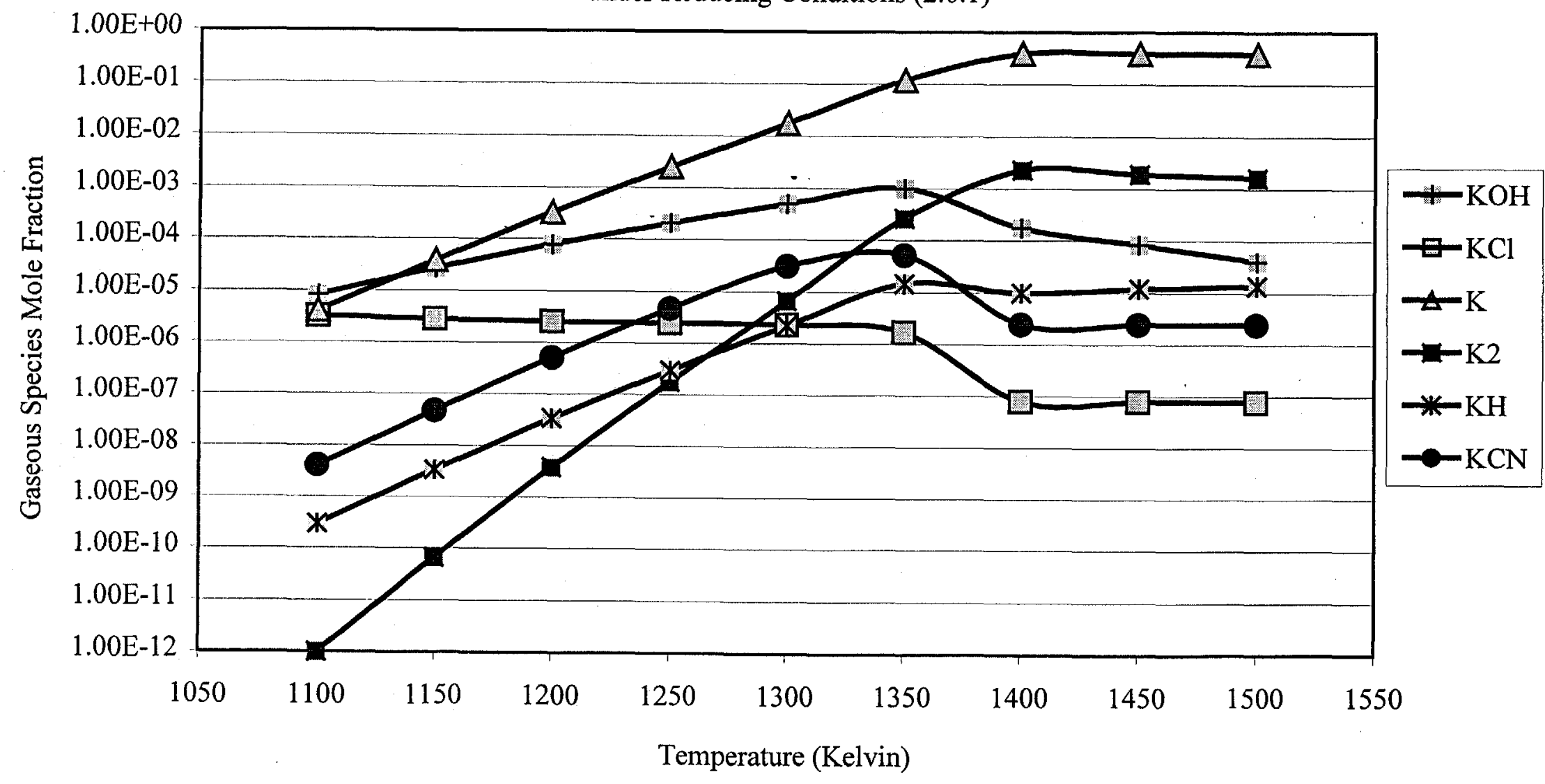

Figure A.33 Potassium Gaseous Species Mole Fraction for $\mathrm{K}_{2} \mathrm{CO}_{3}$ and a Lurgi Off-Gas with WC under Reducing Conditions (2.6.1). 
Potassium Gaseous Species Mole Fraction vs Temperature for $\mathrm{K}_{2} \mathrm{CO}_{3}$ and a Lurgi Off-Gas with $\mathrm{CaO}$

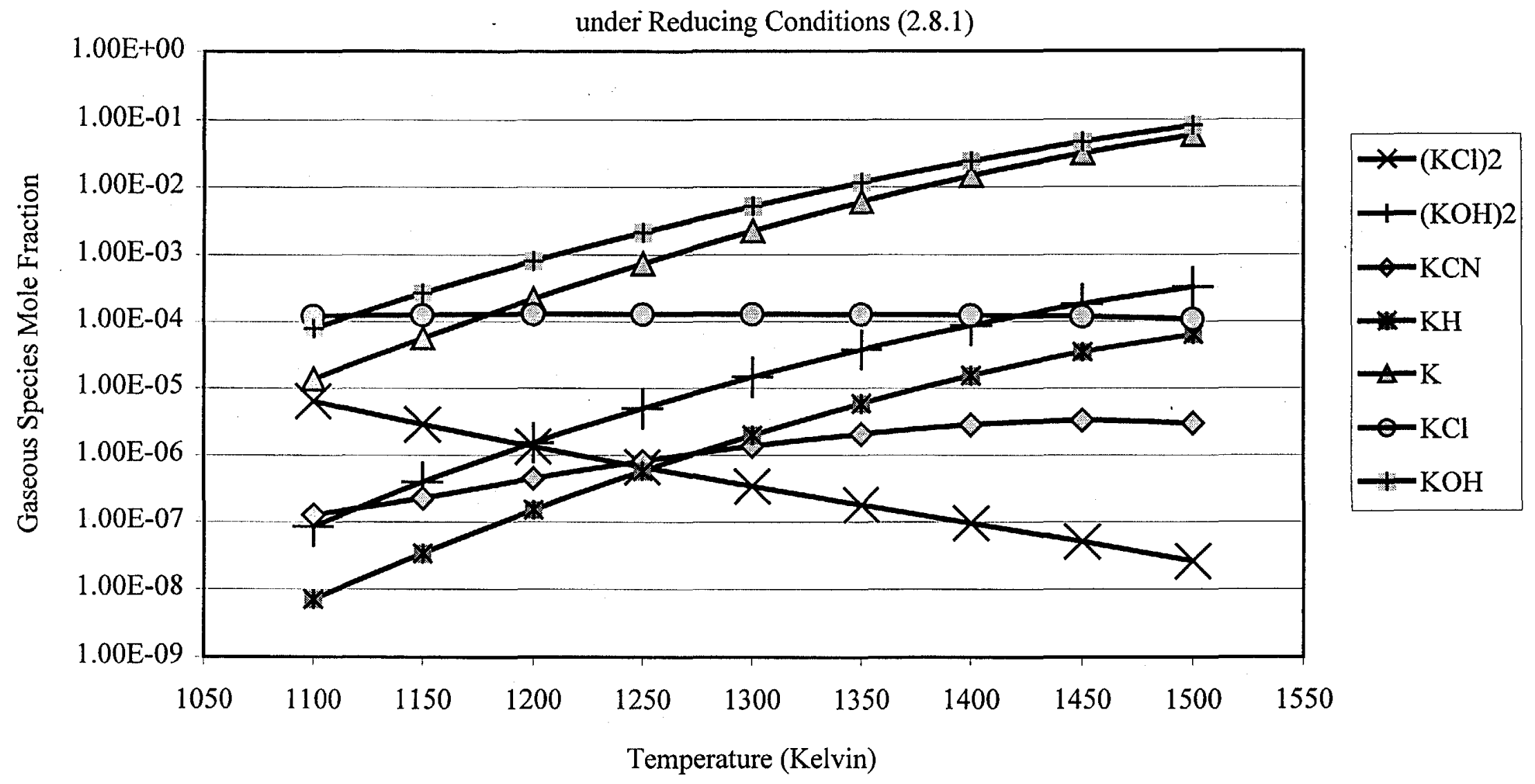

Figure A.34 Potassium Gaseous Species Mole Fraction for $\mathrm{K}_{2} \mathrm{CO}_{3}$ and a Lurgi Off-Gas with $\mathrm{CaO}$ under Reducing Conditions (2.8.1). 


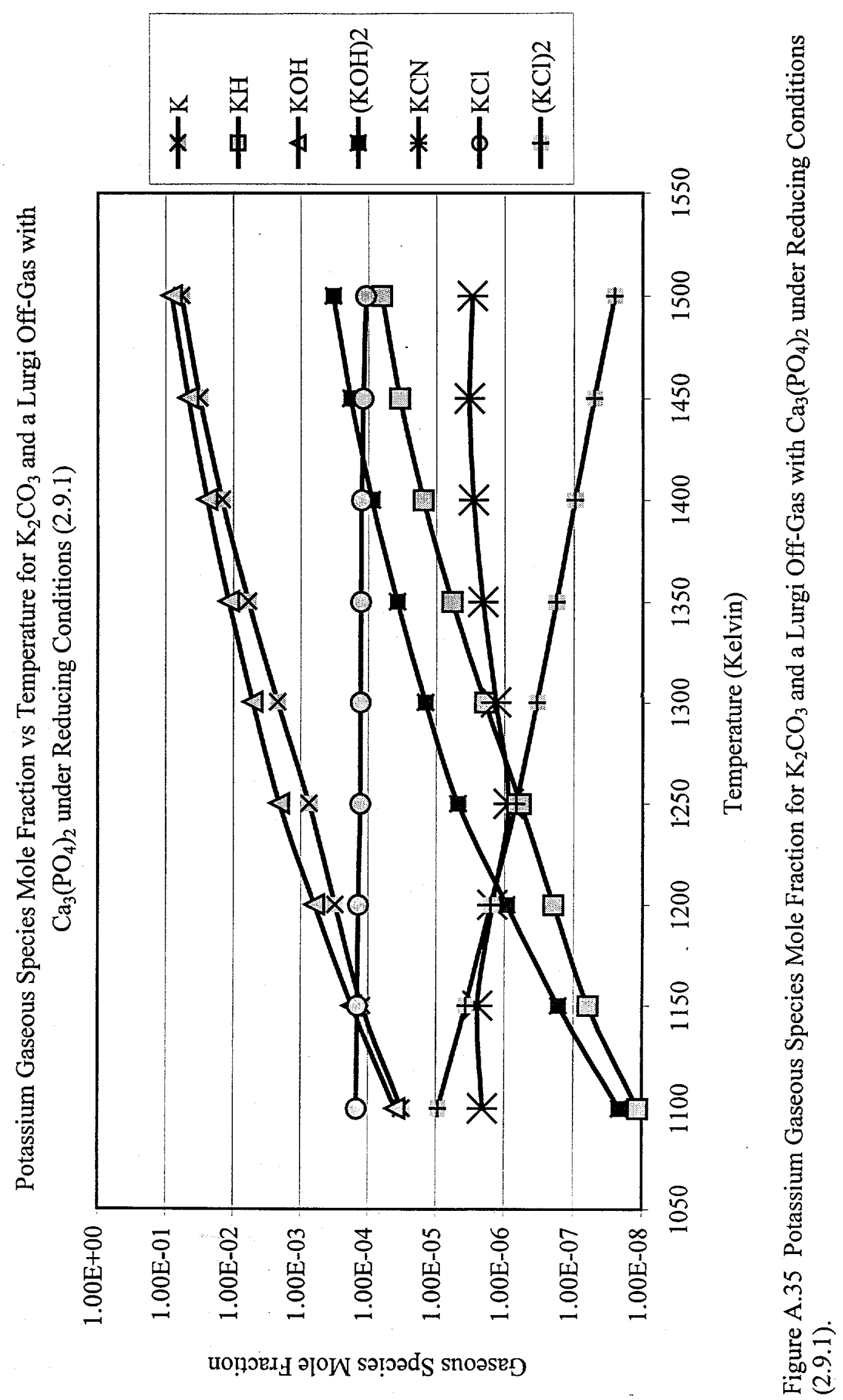




\section{A.6c) Low Temperature/Oxidizing Condition Simulations}

This section examines various nitrates' ability to capture sulfur under oxidizing conditions at low temperature. The simulations were performed for two specific areas. The first step determined which of the nitrates did the best job capturing sulfur. After completing that section, the designated salt was combined with the set of supports in Table A. 1 to see if sulfur capture was a function of a "nonreactive" support. Table A.11 contains the reactant molar ratios inputted into the Equilib program. The simulations were run from $500-1100 \mathrm{~K}$, taking equilibrium species information every $50 \mathrm{~K}$.

Figure A.36 contains the $\mathrm{SO}_{2}$ mole fraction versus temperature for these simulations. The $\mathrm{SO}_{2}$ concentration for all of the salts at the lower end of the temperature range is extremely low, but clearly $\mathrm{NaNO}_{3}$ and $\mathrm{KNO}_{3}$ are the most effective. Around $950 \mathrm{~K}$ there is a distinct change in the $\mathrm{NaNO}_{3}$ curve caused by it dissociating. $\mathrm{AgNO}_{3}$ is unstable immediately and only captures sulfur up to $950 \mathrm{~K}$, while $\mathrm{LiNO}_{3}$ dissociates around $650 \mathrm{~K}$. All of the nitrates capture sulfur aseither a solid or liquid sulfate.

Both $\mathrm{NaNO}_{3}$ and $\mathrm{KNO}_{3}$ do roughly the same job removing the sulfur from the gas phase, except at the upper end of the temperature range tested. $\mathrm{KNO}_{3}$ does have the advantage that it is stable over the entire temperature range. From this perspective it appears that $\mathrm{KNO}_{3}$ is the logical choice to test with the remainder of the supports. Before proceeding it is important to compare the remainder of the gaseous species associated with these two salts found in Figures A.37-A.40. Figure A.37 and A.38 show the significant non-salt related gaseous species for $\mathrm{NaNO}_{3}$ and $\mathrm{KNO}_{3}$ respectively. In both cases, there are very high levels of $\mathrm{N}_{2}$ and $\mathrm{O}_{2}$, due to the nitrates partially dissociating into these components. There also were significant amounts of $\mathrm{CO}_{2}$ and $\mathrm{H}_{2} \mathrm{O}$, which are products of the oxidation of $\mathrm{CO}$ and $\mathrm{H}_{2}$. The $\mathrm{NO}_{\mathrm{X}}$ concentration for both salts crossed the $1 \mathrm{ppm}-\mathrm{v}$ level around $850 \mathrm{~K}$ and topped out at $100 \mathrm{ppm}-\mathrm{v}$ around $1100 \mathrm{~K}$, which is slightly higher than one would expect. In the case of $\mathrm{NaNO}_{3}$, the actual molar amount of $\mathrm{NO}_{\mathrm{x}}$ present after it dissociates at $950 \mathrm{~K}$ was still greater than the system with $\mathrm{KNO}_{3}$. The concentration remains roughly the same due to diluting the gas phase with additional $\mathrm{N}_{2}$ and $\mathrm{O}_{2}$.

Figures A.39 and A.40 describe the salt related gaseous species for the two salts. Both figures show a general increasing trend with temperature for the gaseous salt species. The figures look identical in terms of the shape of the curves and place in regards to the respective gaseous species, but the gas concentrations for the $\mathrm{NaNO}_{3}$ system is in general two orders of magnitude lower than $\mathrm{KNO}_{3}$. In the end, $\mathrm{KNO}_{3}$ was selected to test with the remainder of the supports due to its stability over the entire temperature range.

None of the low temperature oxidizing nitrate systems captured any mercury in the solid or liquid phase. The mercury remains primarily in its elemental form in the gas phase with only a small amount present as $\mathrm{HgO}$. 
Table A.11 FACT entering Molar Ratios for a Koppers-Totzek Off-Gas and Low Temperature Salts with Non-Reactive Supports.

\begin{tabular}{|c|c|c|c|c|}
\hline & $\mathbf{( 8 . 4 . 3 )}$ & $\mathbf{( 9 . 3 . 3 )}$ & $\mathbf{( 1 0 . 3 . 3 )}$ & $\mathbf{( 1 1 . 3 . 3 )}$ \\
\hline Support & $1.000 \mathrm{E}+00$ & $1.000 \mathrm{E}+00$ & $1.000 \mathrm{E}+00$ & $1.000 \mathrm{E}+00$ \\
\hline Salt & $1.204 \mathrm{E}-01$ & $1.611 \mathrm{E}-01$ & $1.354 \mathrm{E}-01$ & $8.060 \mathrm{E}-02$ \\
\hline $\mathbf{C O}$ & $6.037 \mathrm{E}-05$ & $6.476 \mathrm{E}-05$ & $6.193 \mathrm{E}-05$ & $5.651 \mathrm{E}-05$ \\
\hline $\mathbf{C H}_{\mathbf{4}}$ & $1.059 \mathrm{E}-07$ & $1.136 \mathrm{E}-07$ & $1.087 \mathrm{E}-07$ & $9.915 \mathrm{E}-08$ \\
\hline $\mathbf{H}_{\mathbf{2}}$ & $3.040 \mathrm{E}-05$ & $3.260 \mathrm{E}-05$ & $3.118 \mathrm{E}-05$ & $2.846 \mathrm{E}-05$ \\
\hline $\mathbf{C O S}$ & $3.177 \mathrm{E}-08$ & $3.408 \mathrm{E}-08$ & $3.260 \mathrm{E}-08$ & $2.974 \mathrm{E}-08$ \\
\hline $\mathbf{H}_{\mathbf{2}} \mathbf{S}$ & $2.118 \mathrm{E}-07$ & $2.272 \mathrm{E}-07$ & $2.173 \mathrm{E}-07$ & $1.983 \mathrm{E}-07$ \\
\hline $\mathbf{N H}_{\mathbf{3}}$ & $0.000 \mathrm{E}+00$ & $0.000 \mathrm{E}+00$ & $0.000 \mathrm{E}+00$ & $0.000 \mathrm{E}+00$ \\
\hline $\mathbf{C O}_{\mathbf{2}}$ & $1.323 \mathrm{E}-05$ & $1.419 \mathrm{E}-05$ & $1.357 \mathrm{E}-05$ & $1.238 \mathrm{E}-05$ \\
\hline $\mathbf{N}_{\mathbf{2}}$ & $1.901 \mathrm{E}-04$ & $2.040 \mathrm{E}-04$ & $1.951 \mathrm{E}-04$ & $1.780 \mathrm{E}-04$ \\
\hline $\mathbf{O}_{\mathbf{2}}$ & $5.020 \mathrm{E}-05$ & $5.385 \mathrm{E}-05$ & $5.151 \mathrm{E}-05$ & $4.700 \mathrm{E}-05$ \\
\hline $\mathbf{A r}$ & $2.118 \mathrm{E}-07$ & $2.272 \mathrm{E}-07$ & $2.173 \mathrm{E}-07$ & $1.983 \mathrm{E}-07$ \\
\hline $\mathbf{H g}$ & $5.524 \mathrm{E}-12$ & $5.925 \mathrm{E}-12$ & $5.667 \mathrm{E}-12$ & $5.171 \mathrm{E}-12$ \\
\hline $\mathbf{H C l}$ & $8.285 \mathrm{E}-08$ & $8.888 \mathrm{E}-08$ & $8.500 \mathrm{E}-08$ & $7.756 \mathrm{E}-08$ \\
\hline
\end{tabular}


$\mathrm{SO}_{2}$ Mole Fraction vs Temperature for a Koppers-Totzek Gasifier and Low Temperature Salts with a

Non-Reactive Support under Oxidizing Conditions

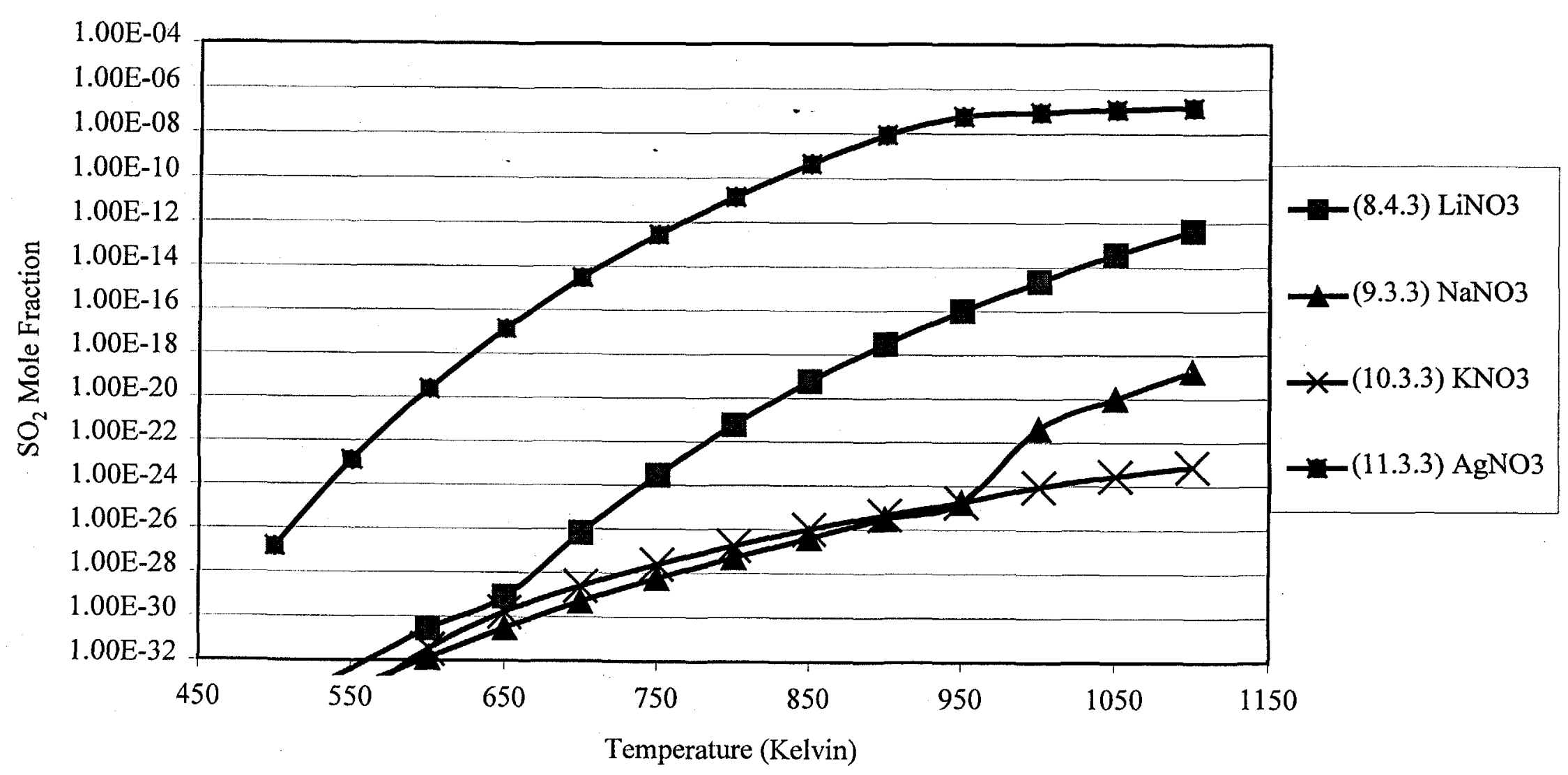

Figure A.36 $\mathrm{SO}_{2}$ Mole Fraction for a Koppers-Totzek Off-Gas and Low Temperature Salts with a Non-Reactive Support under Oxidizing Conditions. 


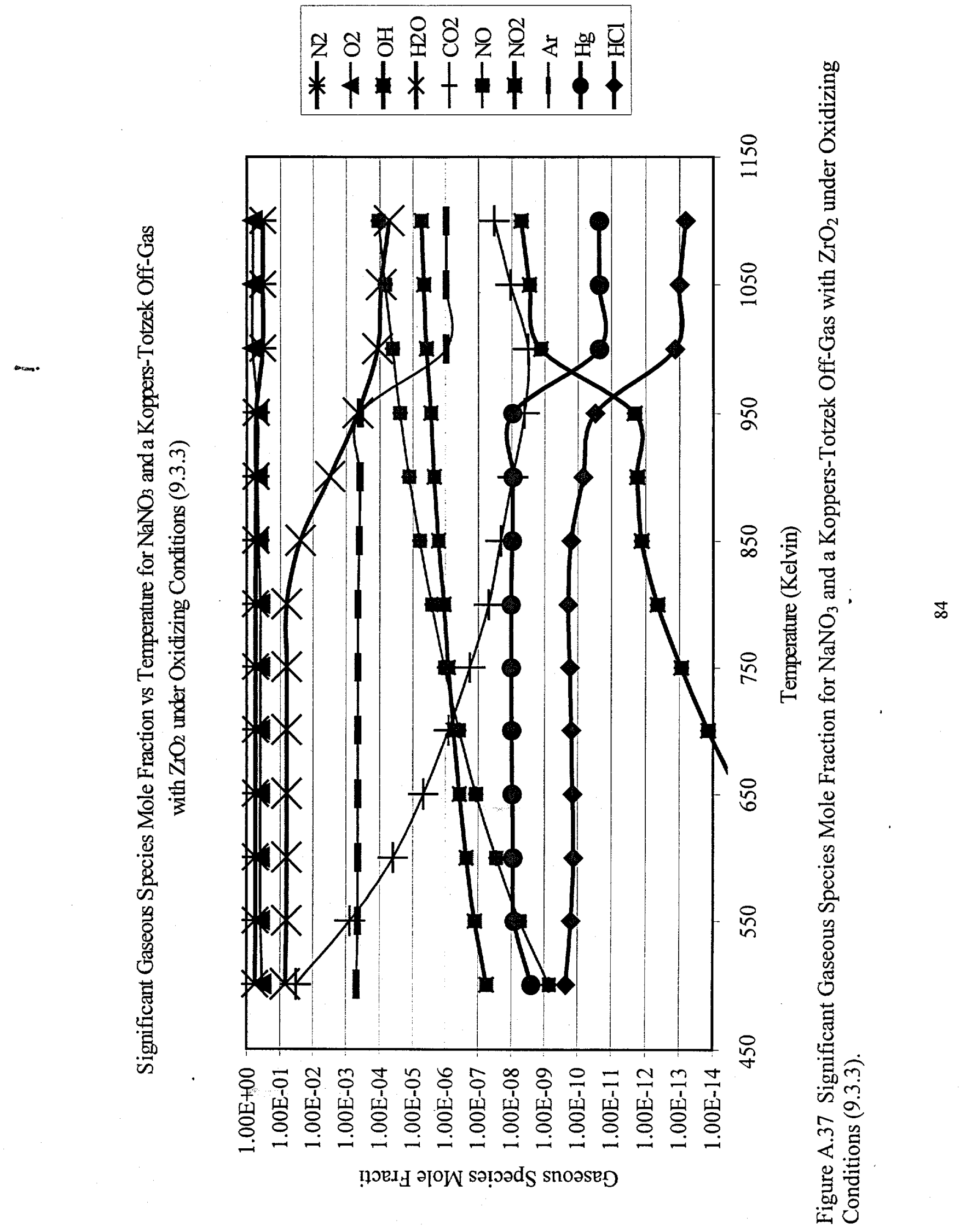


Significant Gaseous Species Mole Fraction vs Temperature for $\mathrm{KNO}_{3}$ and a Koppers-Totzek Off-Gas with $\mathrm{ZrO}_{2}$ under Oxidizing Conditions (10.3.3)

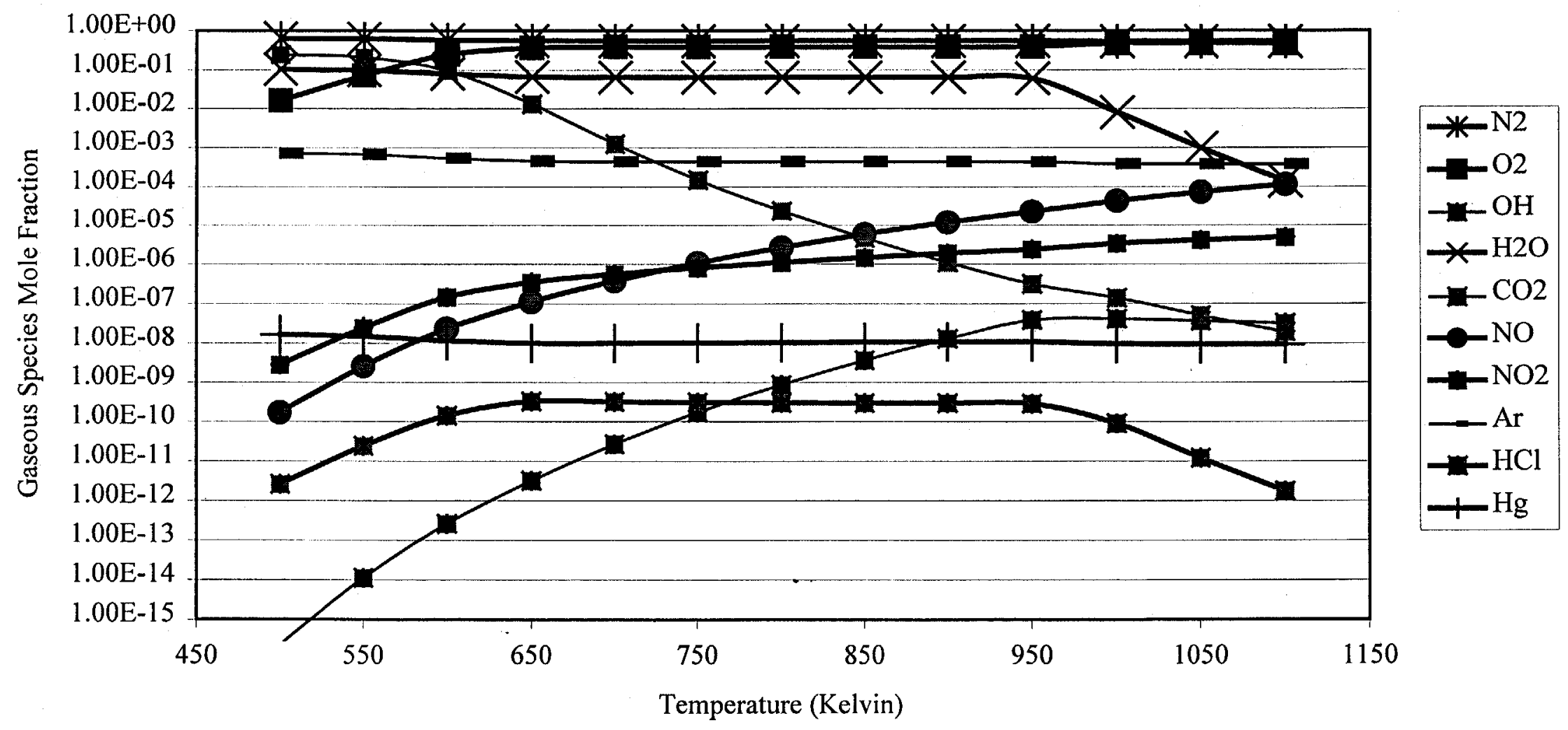

Figure A.38 Significant Gaseous Species Mole Fraction for $\mathrm{KNO}_{3}$ and a Koppers-Totzek Off-Gas with $\mathrm{ZrO}_{2}$ under Oxidizing Conditions (10.3.3). 
Sodium Gaseous Species Mole Fraction vs Temperature for $\mathrm{NaNO}_{3}$ and a Koppers-Totzek Off-Gas with $\mathrm{ZrO}_{2}$ under Oxidizing Conditions

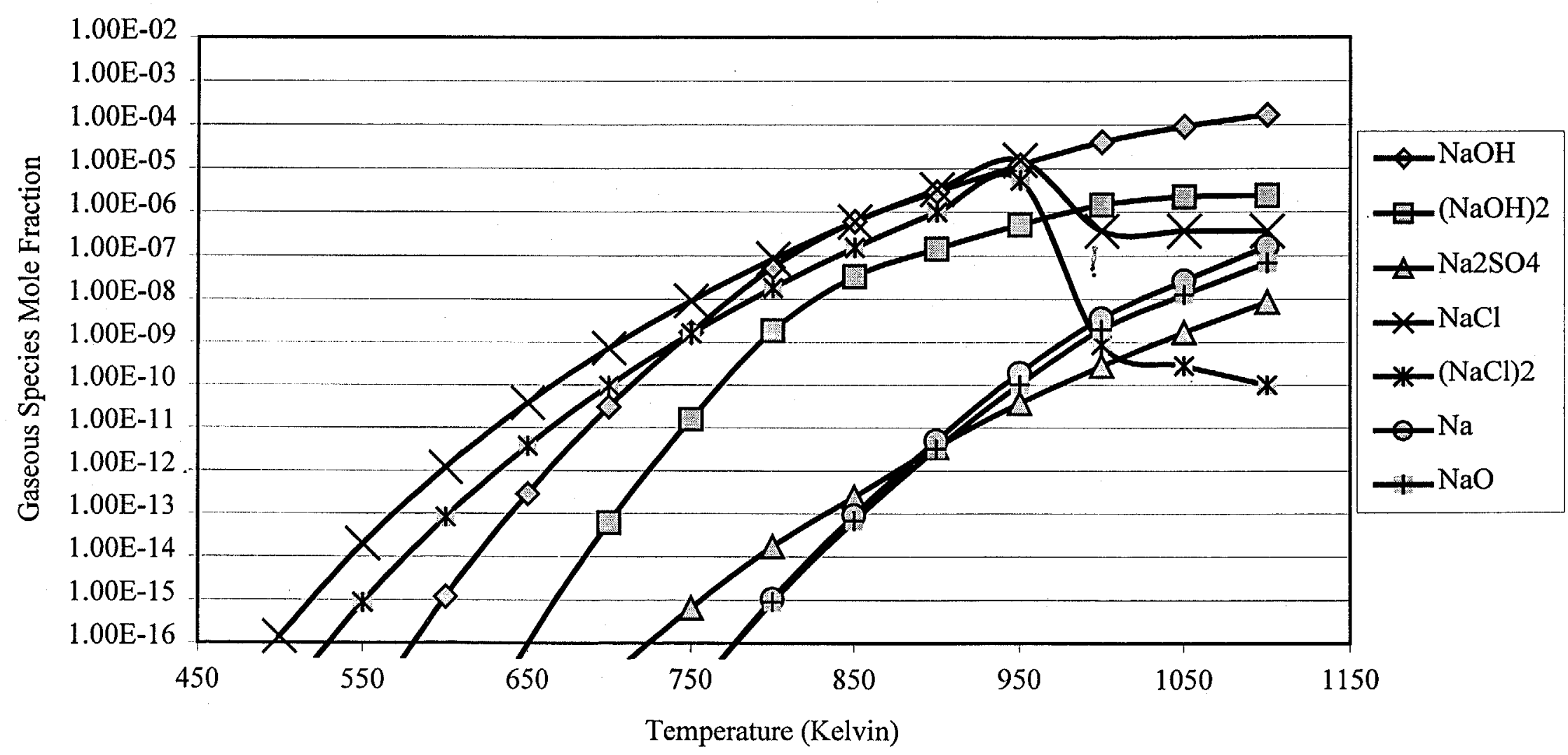

Figure A.39 Sodium Gaseous Species Mole Fraction for $\mathrm{NaNO}_{₹}$ and a Koppers-Totzek Off-Gas with $\mathrm{ZrO}_{2}$ under Oxidizing Conditions (9.3.3). 
Potassium Related Gaseous Species Mole Fraction vs Temperature for $\mathrm{KNO}_{3}$ and a Koppers-Totzek OffGas with $\mathrm{ZrO}_{2}$ under Oxidizing Conditions (10.3.3)

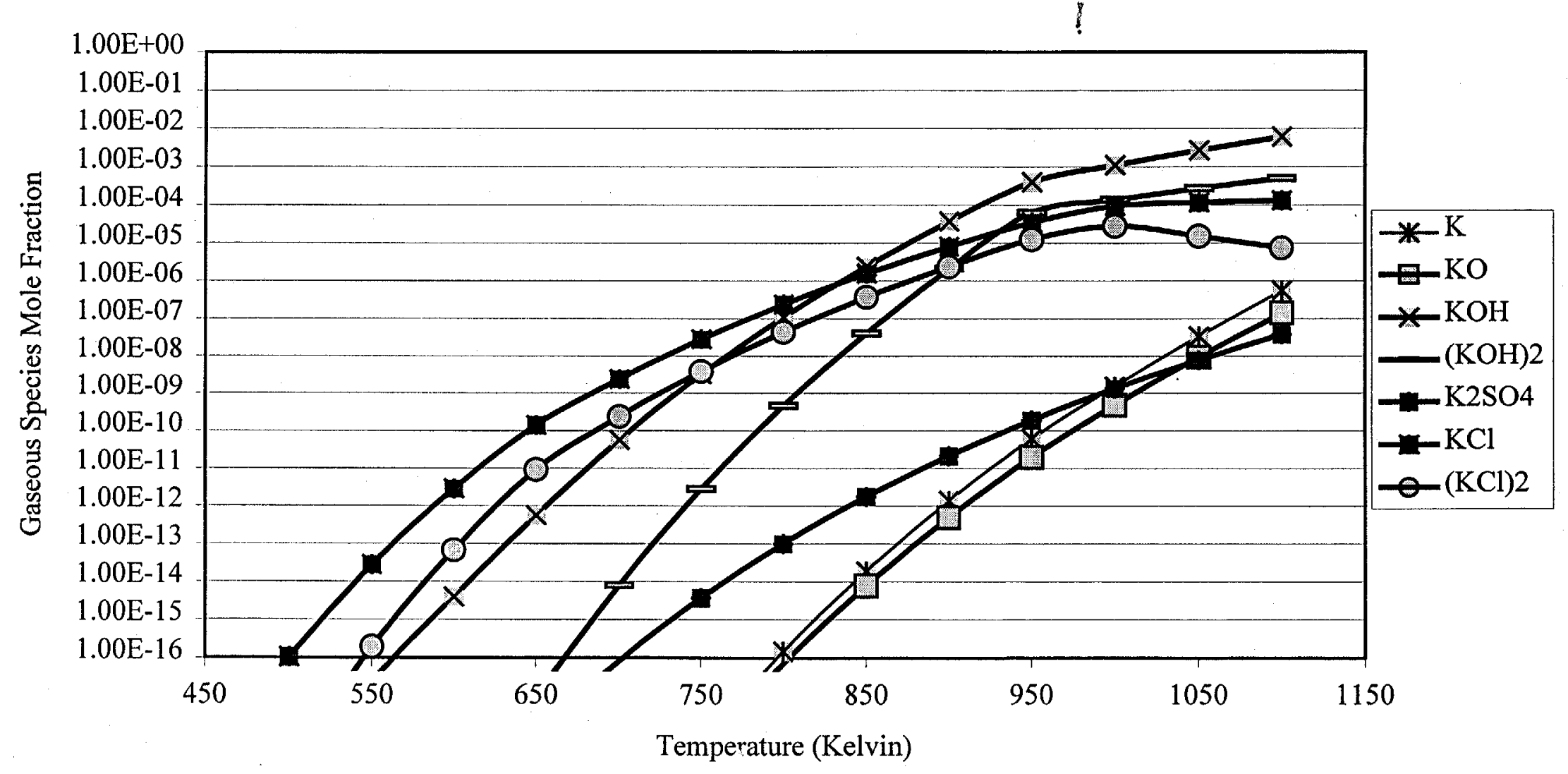

Figure A.40 Potassium Gaseous Species Mole Fraction for $\mathrm{KNO}_{3}$ and a Koppers-Totzek Off-Gas with $\mathrm{ZrO}_{2}$ under Oxidizing Conditions (10.3.3). 
In this section, $\mathrm{KNO}_{3}$ was run with each support to determine if there were any significant differences in sulfur capture for systems where the salt and the support do not react and to examine what products form in the solid and liquid phase for all of the systems tested. Table A.12 contains the reactant molar ratios inputted into the Equilib program for this section.

Figure A.41 plots the $\mathrm{SO}_{2}$ concentration for the various systems tested. Initially, it appears that all of the systems expected to be non-reactive, from earlier results found in Table A.4, captured the same amount of sulfur. The reactive supports still captured a significant amount of sulfur as a solid sulfate but the formation of glassy compounds such as $\mathrm{K}_{2} \mathrm{Si}_{4} \mathrm{O}_{9}, \mathrm{KAl}_{9} \mathrm{O}_{14}$, and $\mathrm{K}_{2} \mathrm{Ti}_{6} \mathrm{O}_{13}$ would further complicate their practical implementation in a high temperature fluidized bed. All of the supports captured sulfur as a sulfate, except WC. Entering this section, it was first thought that both $\mathrm{CaO}$ and $\mathrm{Ca}_{3}\left(\mathrm{PO}_{4}\right)_{2}$ were not going to react with the $\mathrm{KNO}_{3}$. For $\mathrm{CaO}$, small amounts of $\mathrm{Ca}(\mathrm{OH})_{2}$ and $\mathrm{CaCO}_{3}$ are formed from $500-700 \mathrm{~K}$. For $\mathrm{Ca}_{3}\left(\mathrm{PO}_{4}\right)_{2}$, a small amount of $\mathrm{K}_{2} \mathrm{HPO}_{4}(\mathrm{~s})$ is formed over the entire temperature range. The sulfur capture in these systems is still the same when compared to the completely non-reactive supports: $\mathrm{ZrO}_{2}, \mathrm{NiO}$, and $\mathrm{Fe}_{2} \mathrm{O}_{3}$.

Important gaseous species are plotted in Figures A.42-A.46 for NiO, $\mathrm{Fe}_{2} \mathrm{O}_{3}$, $\mathrm{WC}, \mathrm{CaO}$, and $\mathrm{Ca}_{3}\left(\mathrm{PO}_{4}\right)_{2}$ respectively. All of the systems resemble each other with the exception of WC. In the WC system, oxygen reacted with WC to form $\mathrm{WO}_{2}$. This reaction used up a majority of the oxygen present in the system causing it to behave as if in a reduced state. For this system, there actually was no sulfur capture in the liquid or solid phase. The reason the $\mathrm{SO}_{2}$ concentration in Figure A.41 was lower in this system compared to the systems using $\mathrm{SiO}_{2}, \mathrm{Al}_{2} \mathrm{O}_{3}$, and $\mathrm{TiO}_{2}$ was a result of the sulfur remaining in its reduced form, $\mathrm{H}_{2} \mathrm{~S}$. Appropriately, Figure A.44 shows a high $\mathrm{H}_{2} \mathrm{~S}$ concentration. As stated previously, the remainder of supports all exhibited similar gaseous species concentration. Moderate levels of $\mathrm{NO}_{\mathrm{x}}$ and significant combustion products were present. Again, all of the mercury entering the system remained in the gas phase.

Figures A.47-50 show the significant salt related species for the non-reactive supports. There was very little difference in the salt speciation for the various supports tested. For low temperature oxidizing conditions, $\mathrm{KNO}_{3}$ and $\mathrm{NaNO}_{3}$ capture significant amounts of sulfur in the solid phase. As a whole, sulfur capture is not a function of the support particle used when the support did not react substantially with the salt or oxygen present in the system. Based on the very low equilibrium concentrations of $\mathrm{SO}_{2}$ and only moderate levels of $\mathrm{NO}_{x}$, the low temperature oxidation of an off-gas from a gasifier in the presence of $\mathrm{KNO}_{3}$ or $\mathrm{NaNO}_{3}$ demonstrates the necessary qualities for its implementation as a hot gas clean-up strategy. 
Table A.12 FACT entering Molar Ratios for $\mathrm{KNO}_{3}$ and a Koppers-Totzek Off Gas with various Supports under Oxidizing Conditions.

\begin{tabular}{|c|c|c|c|c|}
\hline & $(10.1 .3)$ & $(10.2 .3)$ & $(10.4 .3)$ & $(10.5 .3)$ \\
\hline Support & $1.00 \mathrm{E}+0$ & $1.000 \mathrm{E}+00$ & $1.000 \mathrm{E}+00$ & $1.000 \mathrm{E}+00$ \\
\hline Salt & $6.603 \mathrm{E}-2$ & $1.121 \mathrm{E}-01$ & $8.209 \mathrm{E}-02$ & $1.755 \mathrm{E}-01$ \\
\hline $\mathrm{CO}$ & $5.520 \mathrm{E}-5$ & $5.953 \mathrm{E}-05$ & $5.665 \mathrm{E}-05$ & $6.643 \mathrm{E}-05$ \\
\hline $\mathrm{CH}_{4}$ & $9.684 \mathrm{E}-8$ & $1.044 \mathrm{E}-07$ & 9.939E-08 & $1.165 \mathrm{E}-07$ \\
\hline $\mathrm{H}_{2}$ & $2.779 \mathrm{E}-5$ & $2.997 \mathrm{E}-05$ & $2.852 \mathrm{E}-05$ & $3.345 \mathrm{E}-05$ \\
\hline $\mathrm{COS}$ & $2.905 \mathrm{E}-8$ & $3.133 \mathrm{E}-08$ & $2.982 \mathrm{E}-08$ & $3.496 \mathrm{E}-08$ \\
\hline $\mathrm{H}_{2} \mathrm{~S}$ & $1.937 \mathrm{E}-7$ & $2.089 \bar{E}-07$ & $1.988 \mathrm{E}-07$ & $2.331 \mathrm{E}-07$ \\
\hline $\mathrm{NH}_{3}$ & $0.00 \mathrm{E}+0$ & $0.000 \mathrm{E}+00$ & $0.000 \mathrm{E}+00$ & $0.000 \mathrm{E}+00$ \\
\hline $\mathrm{CO}_{2}$ & $1.209 \mathrm{E}-5$ & $1.304 \mathrm{E}-05$ & $1.241 \mathrm{E}-05$ & $1.456 \mathrm{E}-05$ \\
\hline $\mathbf{N}_{2}$ & $1.739 \mathrm{E}-4$ & $1.875 \mathrm{E}-04$ & $1.784 \mathrm{E}-04$ & $2.092 \mathrm{E}-04$ \\
\hline $\mathbf{O}_{2}$ & $4.591 \mathrm{E}-5$ & $4.951 \mathrm{E}-05$ & $4.711 \mathrm{E}-05$ & $5.525 \mathrm{E}-05$ \\
\hline $\mathbf{A r}$ & $1.937 \mathrm{E}-7$ & $2.089 \mathrm{E}-07$ & $1.988 \mathrm{E}-07$ & $2.331 \mathrm{E}-07$ \\
\hline $\mathrm{Hg}$ & $5.051 \mathrm{E}-12$ & $5.447 \mathrm{E}-12$ & $5.184 \mathrm{E}-12$ & $6.078 \mathrm{E}-12$ \\
\hline $\mathbf{H C l}$ & $7.576 \mathrm{E}-8$ & $8.170 \mathrm{E}-08$ & 7.775E-08 & $9.117 \mathrm{E}-08$ \\
\hline & $(10.6 .3)$ & (10.7.3) & $(10.8 .3)$ & $(10.9 .3)$ \\
\hline Support & $1.000 \mathrm{E}+00$ & $1.000 \mathrm{E}+00$ & $1.000 \mathrm{E}+00$ & $1.000 \mathrm{E}+00$ \\
\hline Salt & $2.153 \mathrm{E}-01$ & $8.779 \mathrm{E}-02$ & $6.162 \mathrm{E}-02$ & $3.409 \mathrm{E}-01$ \\
\hline $\mathrm{CO}$ & $7.141 \mathrm{E}-05$ & $5.718 \mathrm{E}-05$ & $5.481 \mathrm{E}-05$ & $9.175 \mathrm{E}-05$ \\
\hline $\mathrm{CH}_{4}$ & $1.253 \mathrm{E}-07$ & $1.003 \mathrm{E}-07$ & $9.615 \mathrm{E}-08$ & $1.610 \mathrm{E}-07$ \\
\hline $\mathbf{H}_{2}$ & $3.596 \mathrm{E}-05$ & $2.879 \mathrm{E}-05$ & $2.760 \mathrm{E}-05$ & $4.620 \mathrm{E}-05$ \\
\hline $\mathrm{COS}$ & $3.759 \mathrm{E}-08$ & $3.010 \mathrm{E}-08$ & $2.885 \mathrm{E}-08$ & $4.829 \mathrm{E}-08$ \\
\hline $\mathbf{H}_{2} \mathrm{~S}$ & $2.506 \mathrm{E}-07$ & $2.006 \mathrm{E}-07$ & $1.923 \mathrm{E}-07$ & $3.219 \mathrm{E}-07$ \\
\hline $\mathrm{NH}_{3}$ & $0.00 \mathrm{E}+00$ & $0.00 \mathrm{E}+00$ & $0.00 \mathrm{E}+00$ & $0.00 \mathrm{E}+00$ \\
\hline $\mathrm{CO}_{2}$ & $1.565 \mathrm{E}-05$ & $1.253 \mathrm{E}-05$ & $1.201 \mathrm{E}-05$ & $2.010 \mathrm{E}-05$ \\
\hline $\mathbf{N}_{2}$ & $2.249 \mathrm{E}-04$ & $1.801 \mathrm{E}-04$ & $1.726 \mathrm{E}-04$ & $2.890 \mathrm{E}-04$ \\
\hline $\mathbf{O}_{2}$ & $5.939 \mathrm{E}-05$ & $4.756 \mathrm{E}-05$ & $4.558 \mathrm{E}-05$ & $7.630 \mathrm{E}-05$ \\
\hline $\mathbf{A r}$ & $2.506 \mathrm{E}-07$ & $2.006 \mathrm{E}-07$ & $1.923 \mathrm{E}-07$ & $3.219 \mathrm{E}-07$ \\
\hline $\mathbf{H g}$ & $6.534 \mathrm{E}-12$ & $5.232 \mathrm{E}-12$ & $5.015 \mathrm{E}-12$ & $8.395 \mathrm{E}-12$ \\
\hline $\mathrm{HCl}$ & $9.801 \mathrm{E}-08$ & $7.848 \mathrm{E}-08$ & $7.522 \mathrm{E}-08$ & $1.259 \mathrm{E}-07$ \\
\hline
\end{tabular}



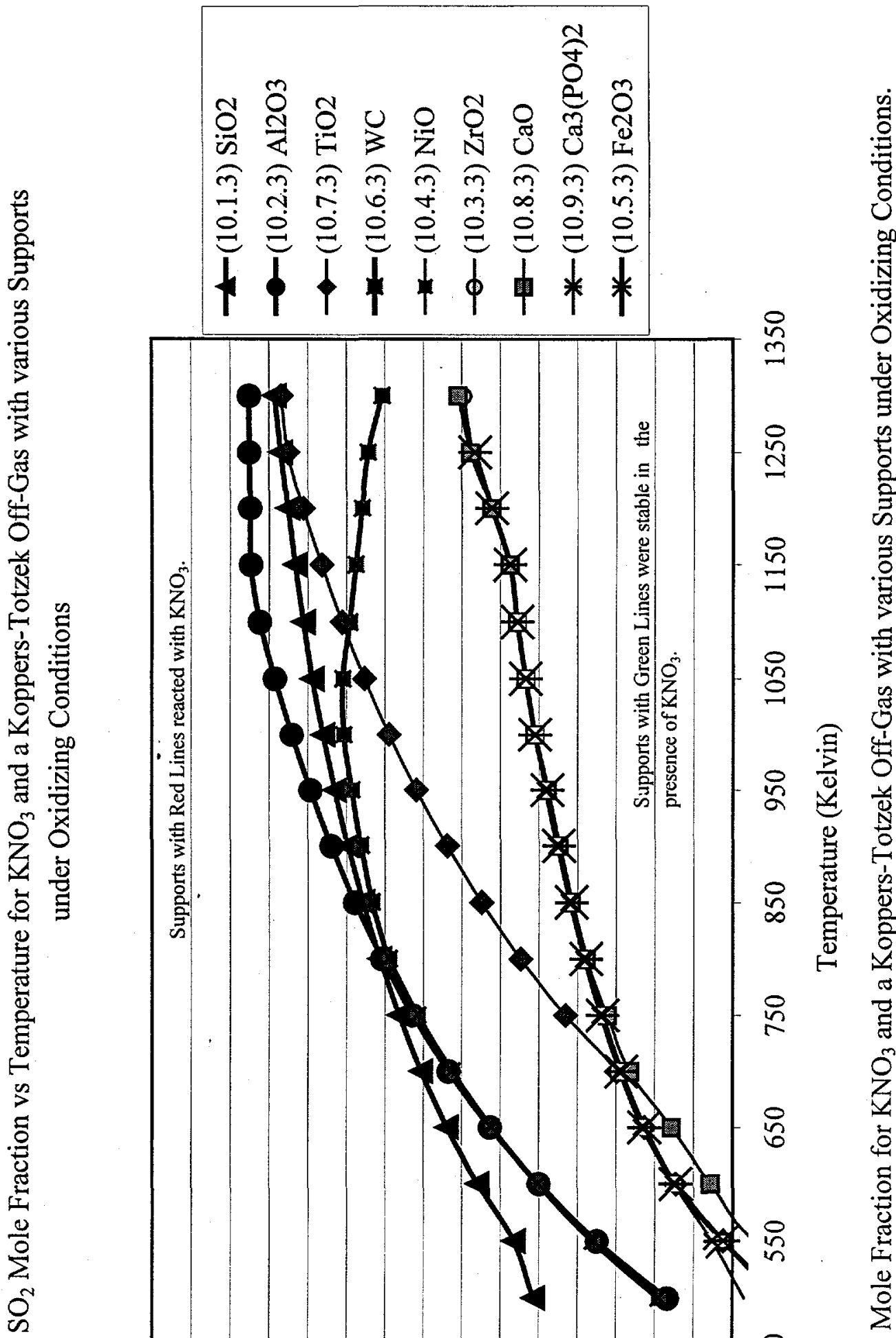
Significant Gaseous Species Mole Fraction vs Temperature for $\mathrm{KNO}_{3}$ and a Koppers-Totzek Gasifier Off Gas with NiO under Oxidizing Conditions (10.4.3)

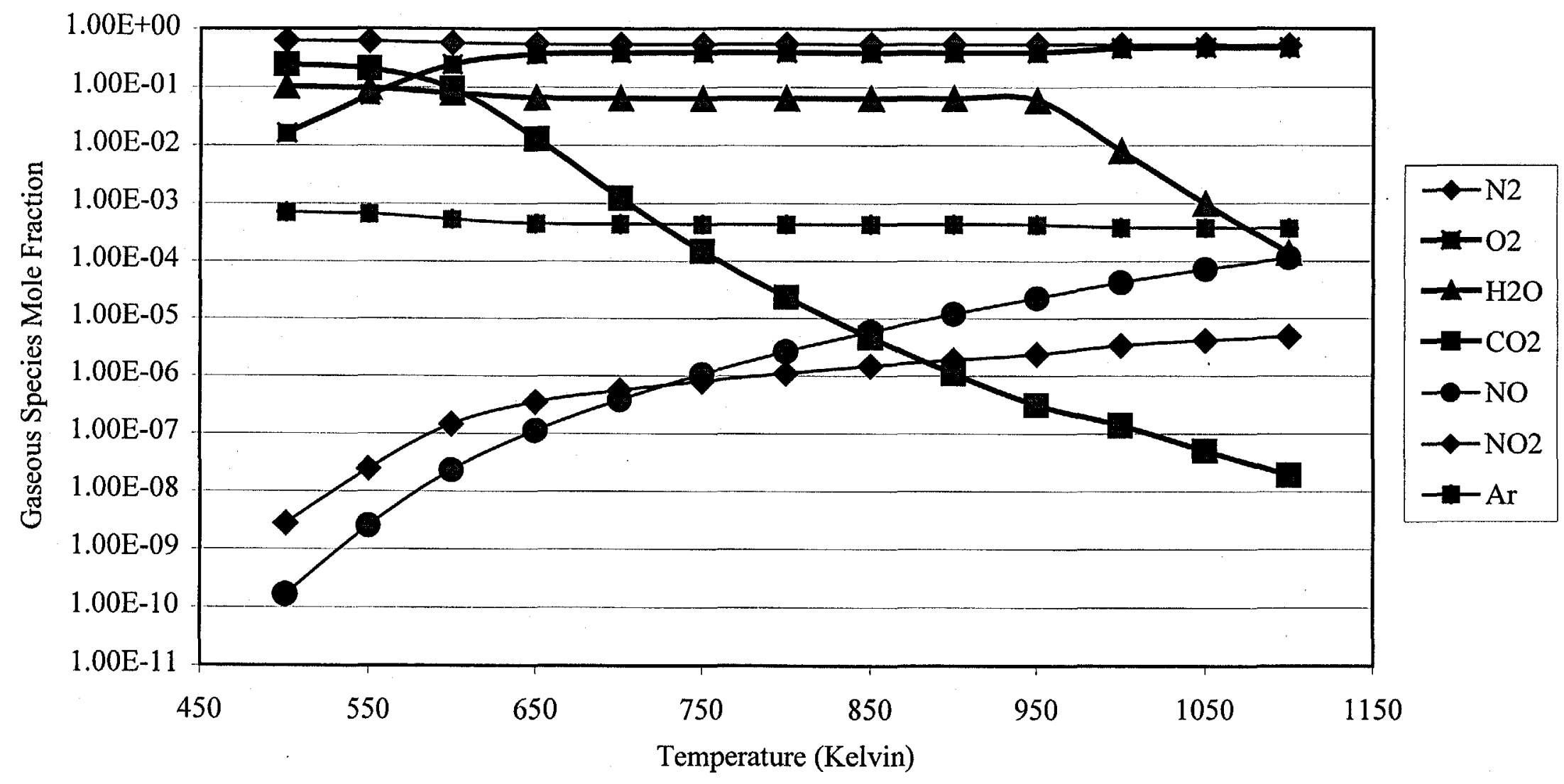

Figure A.42 Significant Gaseous Species Mole Fraction for $\mathrm{KNO}_{3}$ and a Koppers-Totzek Off-Gas with $\mathrm{NiO}$ under Oxidizing Conditions (10.4.3). 
Significant Gaseous Species Mole Fraction vs Temperature for $\mathrm{KNO}_{3}$ and a Koppers-Totzek Off-Gas with $\mathrm{Fe}_{2} \mathrm{O}_{3}$ under Oxidizing Conditions (10.5.3)

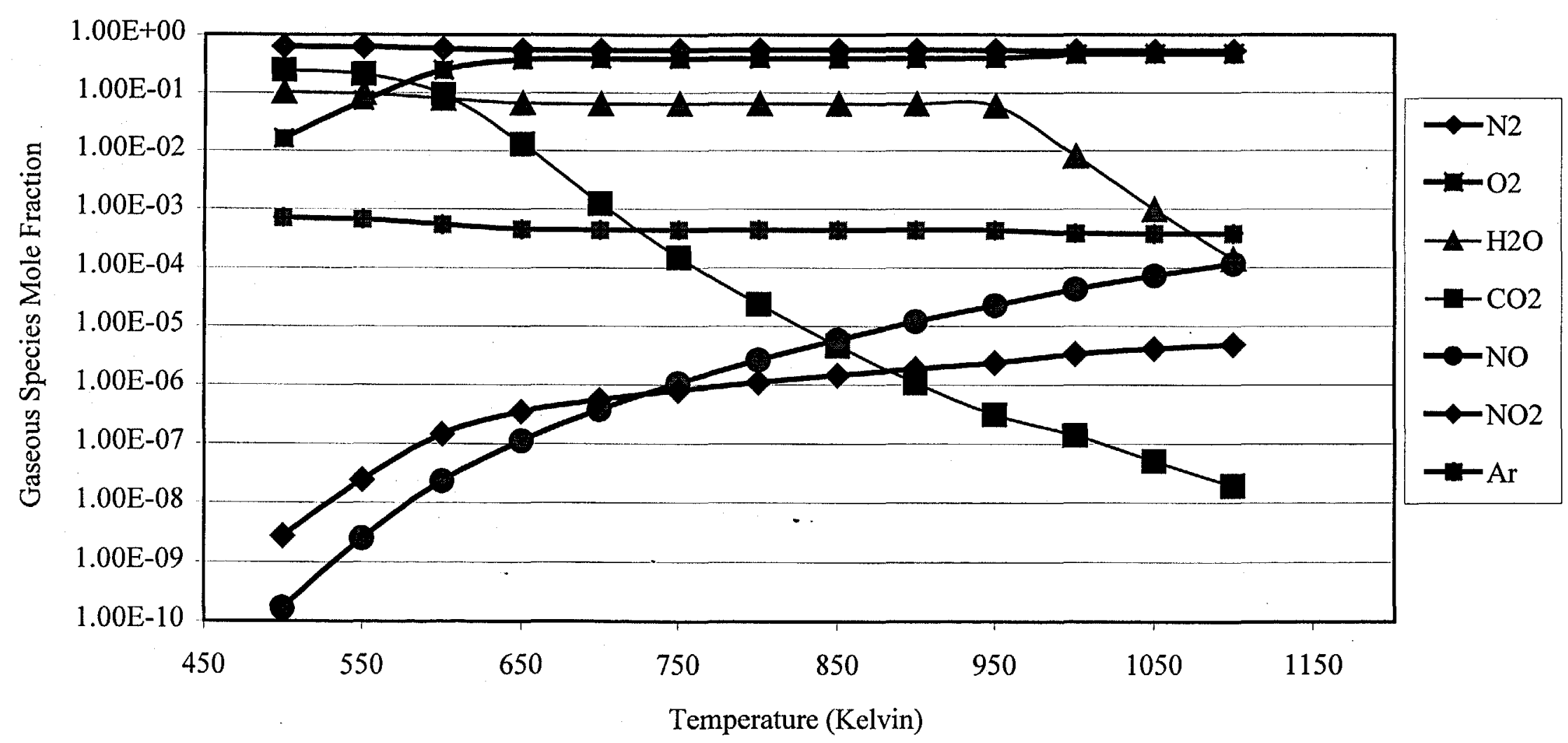

Figure A.43 Significant Gaseous Species Mole Fraction for $\mathrm{KNO}_{3}$ and a Koppers-Totzek Off-Gas with $\mathrm{Fe}_{2} \mathrm{O}_{3}$ under Oxidizing Conditions (10.5.3). 
Gaseous Species Mole Fraction vs Temperature for $\mathrm{KNO}_{3}$ and a Koppers-Totzek Off-Gas with WC under "Oxidizing Conditions" (10.6.3)

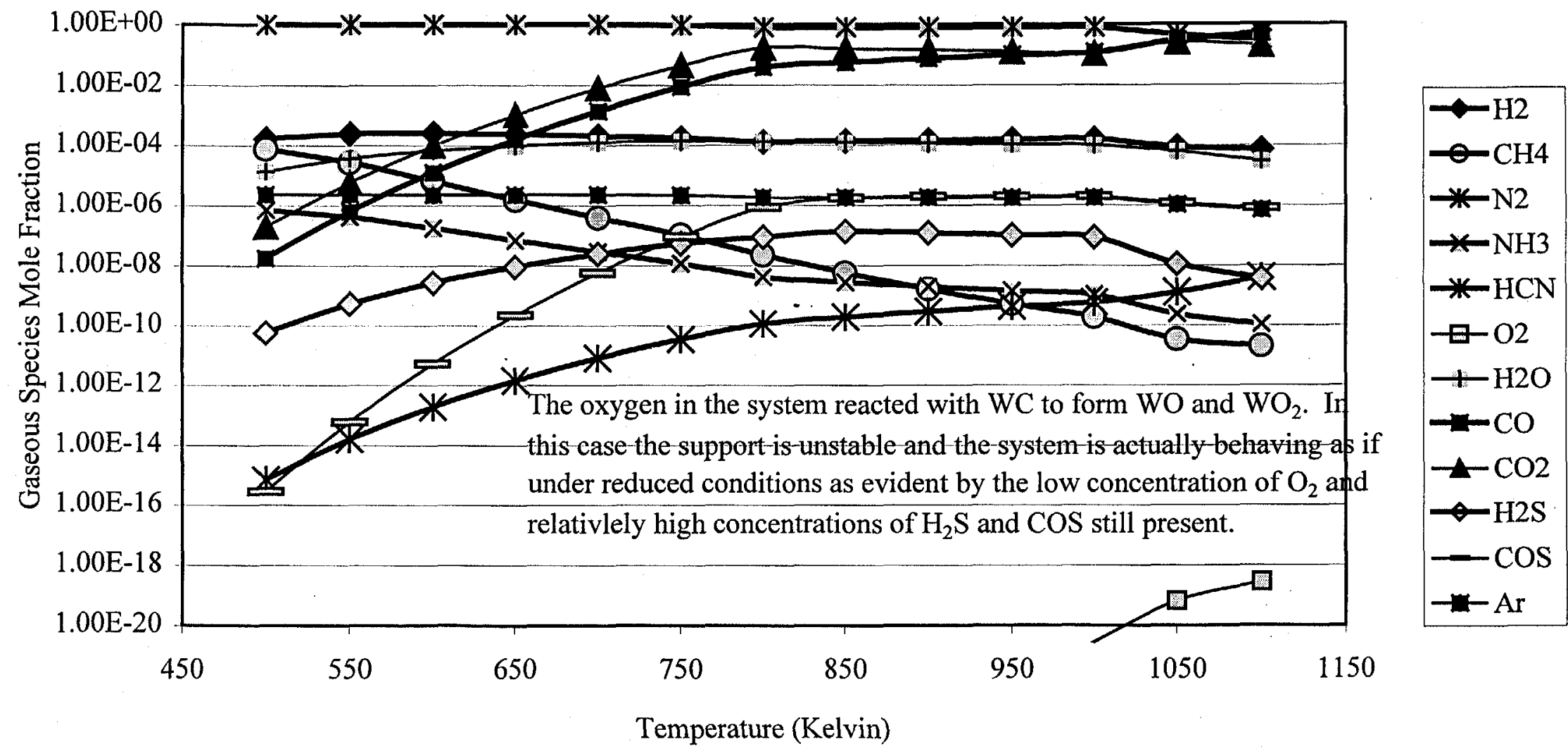

Figure A.44 Significant Gaseous Species Mole Fraction for $\mathrm{KNO}_{3}$ and a Koppers-Totzek Off-Gas with WC under Oxidizing Conditions (10.6.3). 
Significant Gaseous Species Mole Fraction vs Temperature for $\mathrm{KNO}_{3}$ and a Koppers-Totzek Off-Gas with $\mathrm{CaO}$ under Oxidizing Conditions (10.8.3)

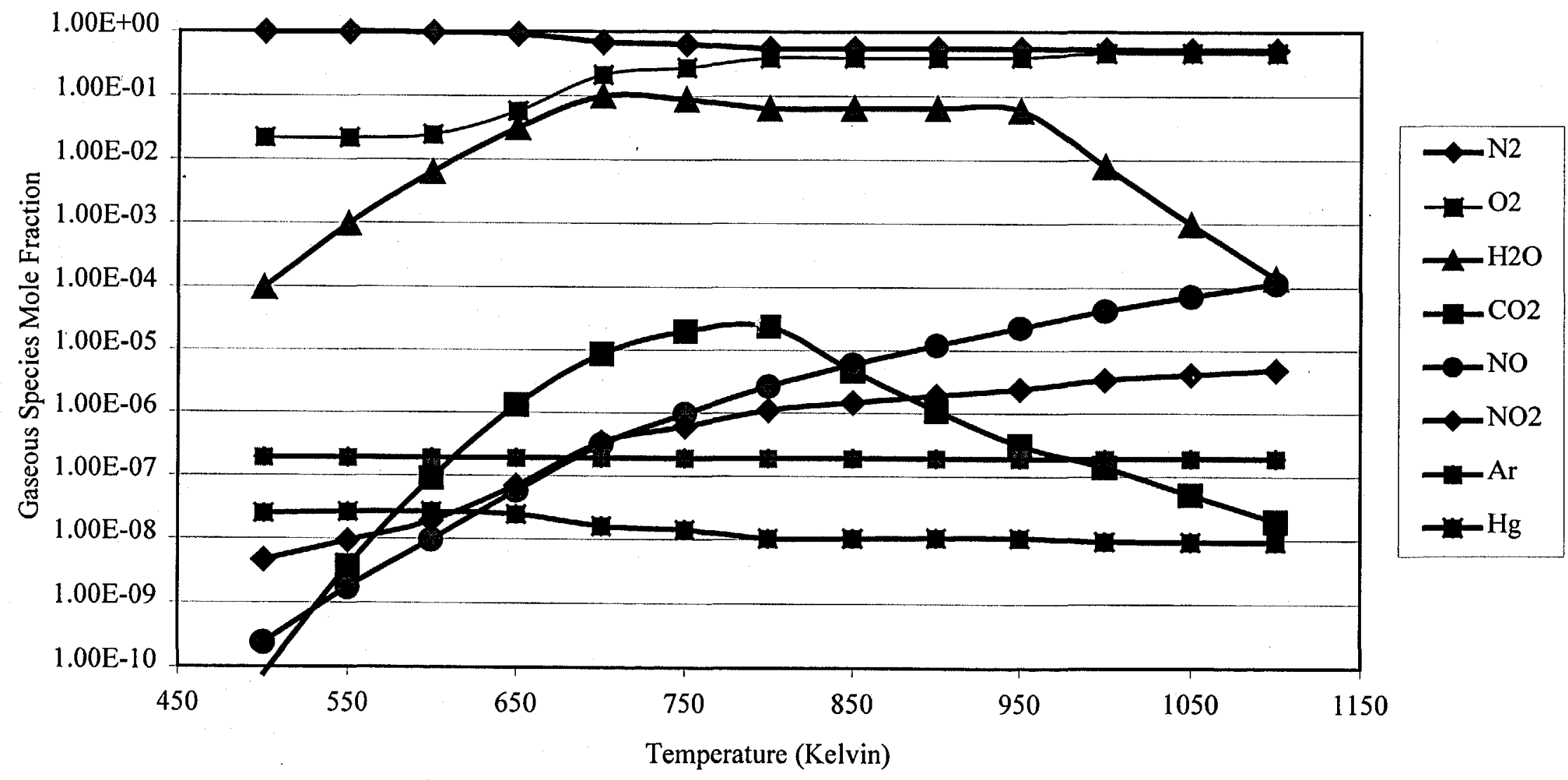

Figure A.45 Significant Gaseous Species Mole Fraction for $\mathrm{KNO}_{3}$ and a Koppers-Totzek Off-Gas with $\mathrm{CaO}$ under Oxidizing Conditions (10.8.3). 
Gaseous Species Mole Fraction vs Temperature for $\mathrm{KNO}_{3}$ and a Koppers-Totzek Off-Gas with $\mathrm{Ca}_{3}\left(\mathrm{PO}_{4}\right)_{2}$ under Oxidizing Conditions (10.9.3)

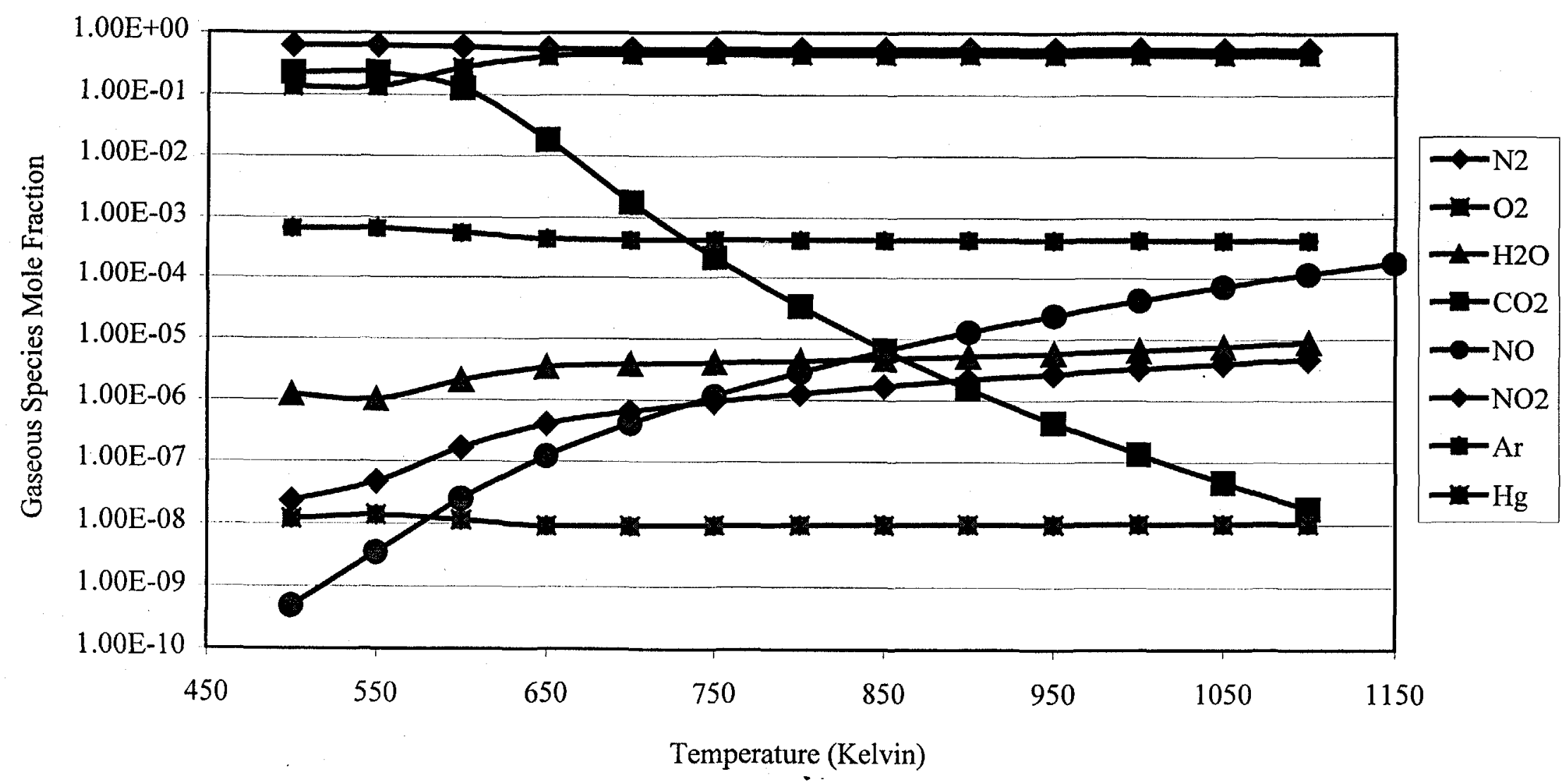

Figure A.46 Significant Gaseous Species Mole Fraction for $\mathrm{KNO}_{3}$ and a Koppers-Totzek Off-Gas with $\mathrm{Ca}_{3}\left(\mathrm{PO}_{4}\right)_{2}$ under Oxidizing Conditions (10.9.3). 
Potassium Gaseous Species Mole Fraction vs Temperature for $\mathrm{KNO}_{3}$ and a Koppers-Totzek Off-Gas with $\mathrm{NiO}$ under Oxidizing Conditions (10.4.3)

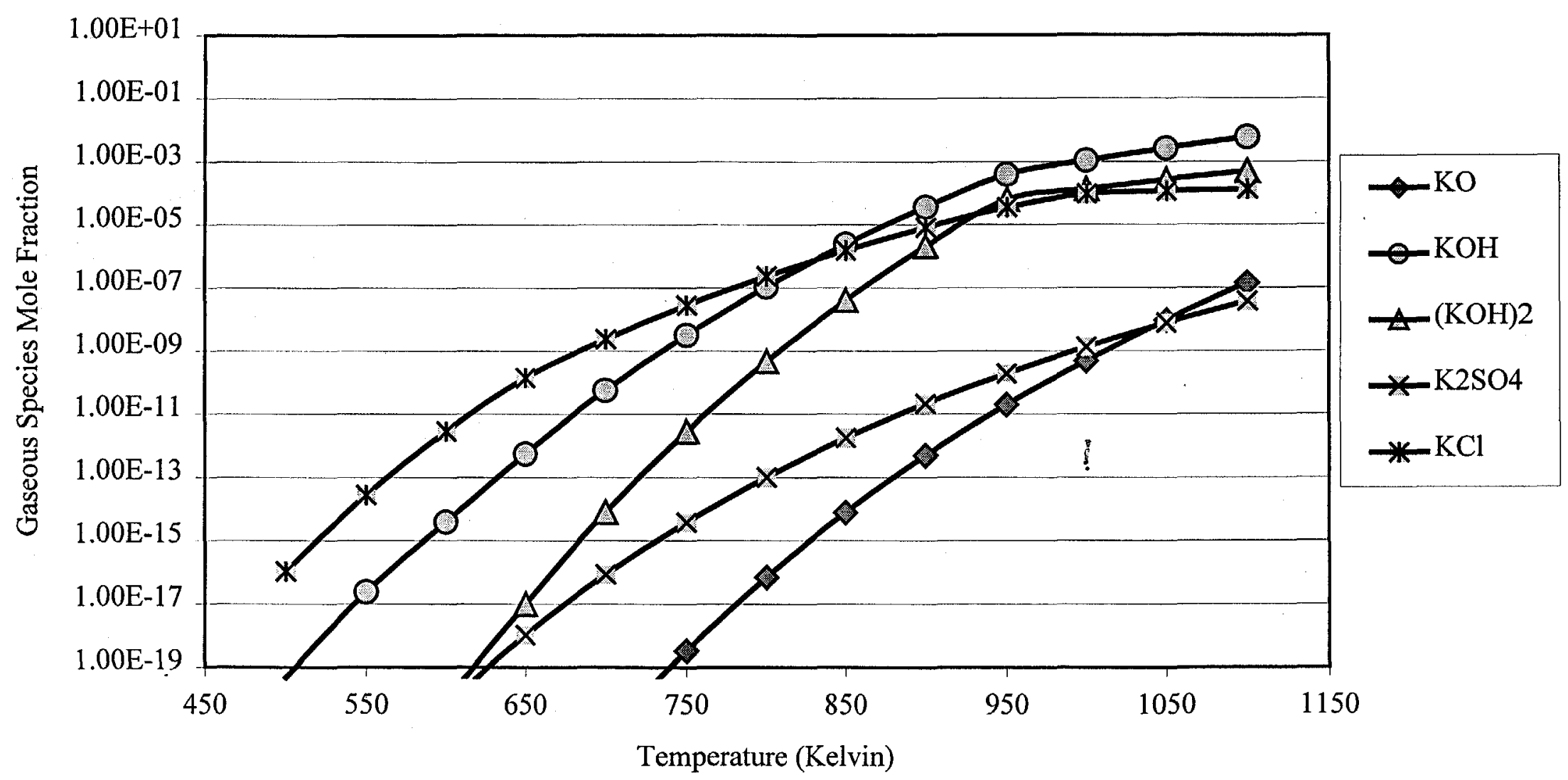

Figure A.47 Potassium Gaseous Species Mole Fraction for $\mathrm{KNO}_{3}$ and a Koppers-Totzek Off-Gas with NiO under Oxidizing Conditions (10.4.3). 
Potassium Gaseous Species Mole Fraction vs Temperature for $\mathrm{KNO}_{3}$ and a Koppers-Totzek Off-Gas with $\mathrm{Fe}_{2} \mathrm{O}_{3}$ under Oxidizing Conditions (10.5.3)

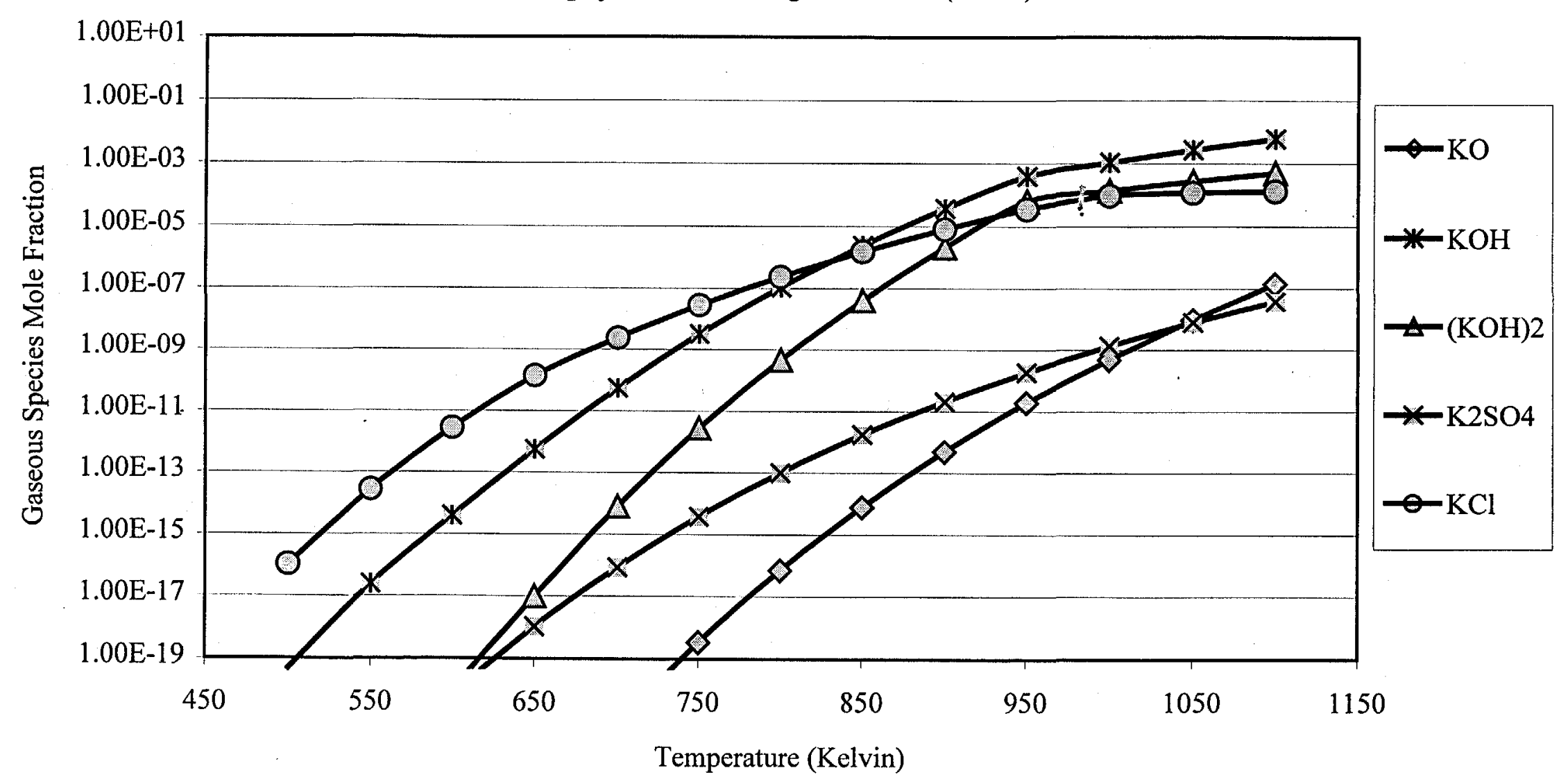

Figure A.48 Potassium Gaseous Species Mole Fraction for $\mathrm{KNO}_{3}$ and a Koppers-Totzek Off-Gas with $\mathrm{Fe}_{2} \mathrm{O}_{3}$ under Oxidizing Conditions (10.5.3). 
Potassium Gaseous Species Mole Fraction vs Temperature for $\mathrm{KNO}_{3}$ and a Koppers-Totzek Off-Gas with $\mathrm{CaO}$ under Oxidizing Conditions (10.8.3)

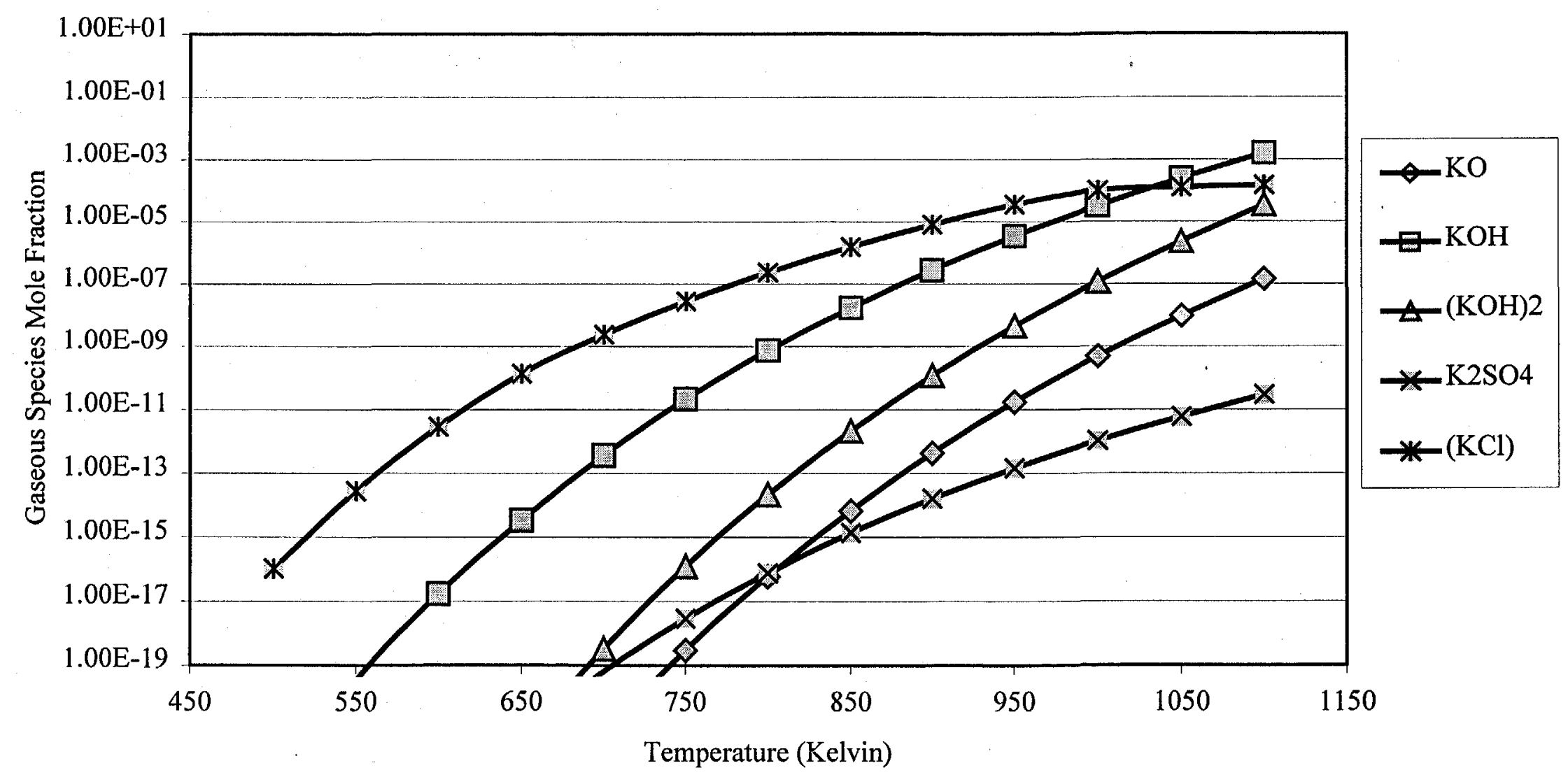

Figure A.49 Potassium Gaseous Species Mole Fraction for $\mathrm{KNO}_{3}$ and a Koppers-Totzek Off-Gas with $\mathrm{CaO}$ under Oxidizing Conditions (10.8.3). 
Potassium Gaseous Species Mole Fraction vs Temperature for $\mathrm{KNO}_{3}$ and a Koppers-Totzek Off-Gas with $\mathrm{Ca}_{3}\left(\mathrm{PO}_{4}\right)_{2}$ under Oxidizing Conditions (10.9.3)

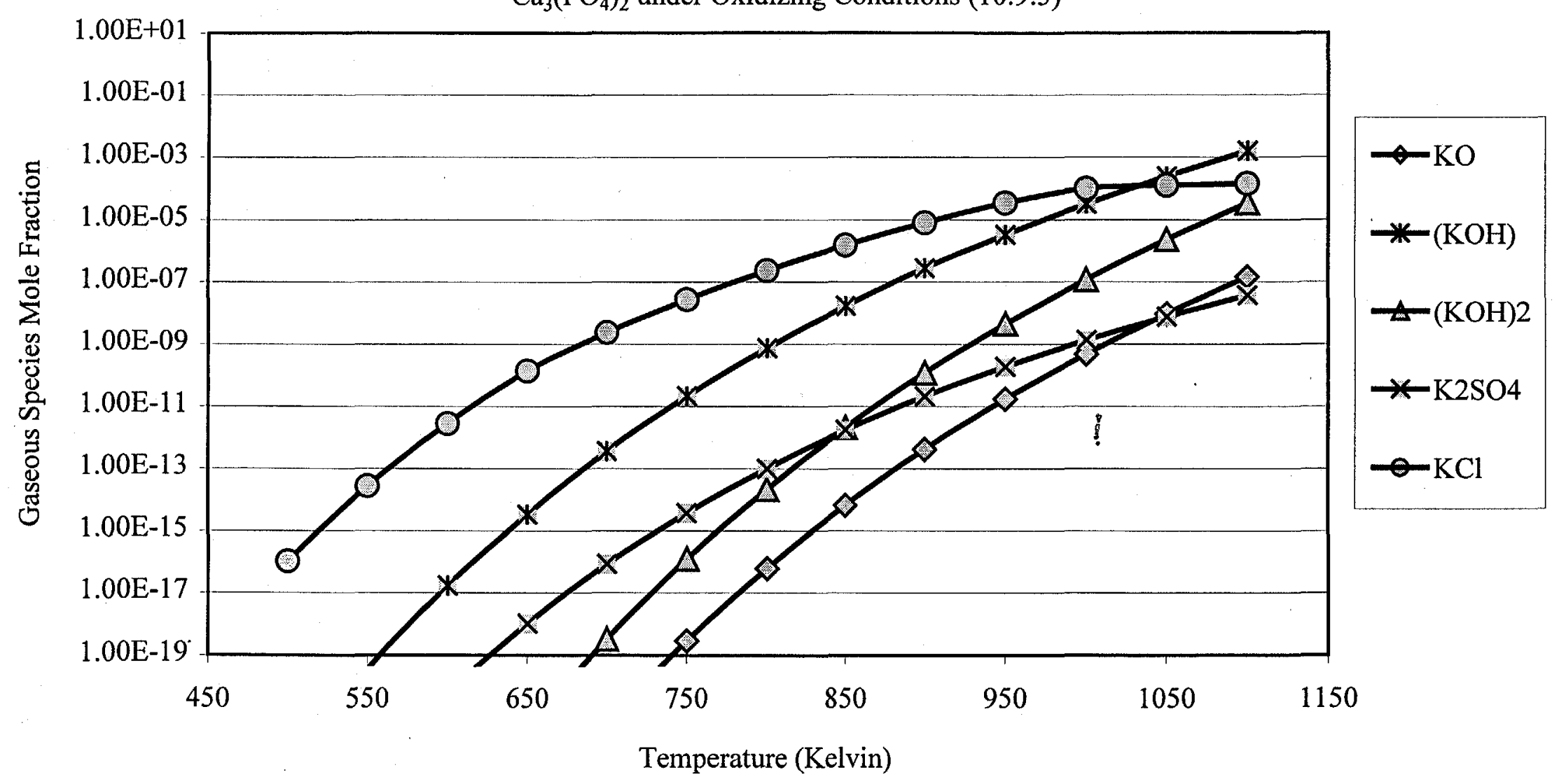

Figure A.50 Potassium Gaseous Species Mole Fraction for $\mathrm{KNO}_{3}$ and a Koppers-Totzek Off-Gas with $\mathrm{Ca}_{3}\left(\mathrm{PO}_{4}\right)_{2}$ under Oxidizing Conditions (10.9.3). 


\section{A.6d) Low Temperature/Reducing Condition Simulations}

This section looked at the nitrates' ability to capture sulfur under reducing conditions. Two main areas were tested, similar to the manner in which previous sections were studied. First, all of the applicable salts were tested with a non-reactive supports and the off-gas from a Winkler Gasifier to determine which salt does the best job as far as sulfur removal and overall stability. The next section ran the selected salt with the remainder of the supports to ascertain if there were any differences as far as sulfur capture for non-reactive systems and also determine the solid and liquid products for all of the systems tested.

The FACT entering molar ratios for the scenarios testing the various nitrates' sulfur capturing capabilities are listed in Table A.13.

The scenarios were run from $500-1100 \mathrm{~K}$ to cover the stable range for the different nitrates. Figures A.51-A.54 contain information on the sulfur containing gaseous species. The amount of sulfur containing species in the gas phase for these systems was extremely fow. Both $\mathrm{KNO}_{3}$ and $\mathrm{NaNO}_{3}$ are far superior compared to $\mathrm{LiNO}_{3}$ and $\mathrm{AgNO}_{3}$ at keeping the sulfur species mole fraction below $10^{-20}$ over the entire temperature range. $\mathrm{AgNO}_{3}$ is unstable over the entire temperature range tested, immediately forming silver sulfate and $\mathrm{Ag}(\mathrm{s}) . \mathrm{LiNO}_{3}$ is stable up to $650 \mathrm{~K}$ at which it completely dissociates releasing nitrogen and oxygen, thus diluting the gas phase. $\mathrm{NaNO}_{3}$ is stable up to $950 \mathrm{~K}$, while $\mathrm{KNO}_{3}$ is stable over the entire temperature range tested. From a stability and sulfur capture standpoint $\mathrm{KNO}_{3}$ is the best choice to test with the rest of the supports.

Initially, the potential for sulfur capture looks very promising, but an inspection of the other equilibrium gas phase constituents shows that a majority of the $\mathrm{H}_{2}$ and $\mathrm{CO}$ was oxidized to $\mathrm{CO}_{2}$ and $\mathrm{H}_{2} \mathrm{O}$. Although the systems were designed to operate under reduced conditions, small amounts of the nitrates dissociate and release nitrogen and oxygen into the gas phase. The sulfur is captured as a sulfate, which is not expected in a system truly operating in a reduced state. Figure A.55 shows the significant gaseous species for the $\mathrm{KNO}_{3}$ system. $\mathrm{CO}$ and $\mathrm{H}_{2}$ are at very low concentrations over the entire temperature range leaving virtually nothing left to oxidize for generating electricity in a molten carbonate fuel cell. Another concern with these systems is the high concentration of $\mathrm{NO}_{\mathrm{x}}$ present at relatively low temperatures tested. At the upper end of the temperature range, $\mathrm{NO}_{\mathrm{x}}$ values are on the order of $100 \mathrm{ppm}-\mathrm{v}$, which is higher than expected in a reduced system. Again, the nitrate dissociation contributes to the formation of $\mathrm{NO}_{\mathrm{x}}$ in systems where it is not expected.

Figure A.55 shows a mercury concentration just over $1 \mathrm{E}-2 \mathrm{ppm}-\mathrm{v}$ that slightly decreases with increasing temperature. The actual molar amount of elemental mercury present in the gas phase is equal to $2.5334 \mathrm{E}-11$ moles. This amount is slightly less than the amount input into FACT of 2.651E-11 moles found in Table A.13. The "missing" mercury remains in the gas phase as $\mathrm{HgO}$.

Figure A.56 shows the potassium gaseous species concentrations as a function of temperature. As expected there were very low levels of potassium gaseous species at the lower temperatures. Around $850 \mathrm{~K}$, the first salt gaseous species 
reached a concentration greater than $1 \mathrm{ppm}-\mathrm{v}$ and topped out at $10000 \mathrm{ppm}-\mathrm{v}$ at the upper end of the temperature range. The other salt species exhibit behavior similar to the potassium gaseous species in relation to the temperature trend. The sodium system curves look similar to those found in Figure A.56, but on average are two orders of magnitude lower than the potassium gaseous species. The highest sodium gaseous species concentration is around $100 \mathrm{ppm}-\mathrm{v}$ at $1100 \mathrm{~K}$ for $\mathrm{NaOH}$. From this perspective $\mathrm{NaNO}_{3}$ is the more attractive candidate. 
Table A.13 FACT entering Molar Ratios for Low Temperature Salts and a Winkler Off-Gas with a Non-Reactive Support under Reducing Conditions.

\begin{tabular}{|c|c|c|c|c|}
\hline & $\mathbf{( 8 . 4 . 2 )}$ & $\mathbf{( 9 . 3 . 2 )}$ & $\mathbf{( 1 0 . 3 . 2}$ & $\mathbf{( 1 1 . 3 . 2 )}$ \\
\hline Support & $1.000 \mathrm{E}+00$ & $1.000 \mathrm{E}+00$ & $1.000 \mathrm{E}+00$ & $1.000 \mathrm{E}+00$ \\
\hline Salt & $1.204 \mathrm{E}-01$ & $1.611 \mathrm{E}-01$ & $1.354 \mathrm{E}-01$ & $8.060 \mathrm{E}-02$ \\
\hline $\mathbf{C O}$ & $2.826 \mathrm{E}-04$ & $3.024 \mathrm{E}-04$ & $2.897 \mathrm{E}-04$ & $2.652 \mathrm{E}-04$ \\
\hline $\mathbf{C H} \mathbf{H}_{\mathbf{4}}$ & $9.421 \mathrm{E}-06$ & $1.008 \mathrm{E}-05$ & $9.656 \mathrm{E}-06$ & $8.841 \mathrm{E}-06$ \\
\hline $\mathbf{H}_{\mathbf{2}}$ & $2.415 \mathrm{E}-04$ & $2.584 \mathrm{E}-04$ & $2.475 \mathrm{E}-04$ & $2.266 \mathrm{E}-04$ \\
\hline $\mathbf{C O S}$ & $3.140 \mathrm{E}-07$ & $3.360 \mathrm{E}-07$ & $3.219 \mathrm{E}-07$ & $2.947 \mathrm{E}-07$ \\
\hline $\mathbf{H}_{\mathbf{2}} \mathbf{S}$ & $9.421 \mathrm{E}-07$ & $1.008 \mathrm{E}-06$ & $9.656 \mathrm{E}-07$ & $8.841 \mathrm{E}-07$ \\
\hline $\mathbf{N H}_{\mathbf{3}}$ & $0.000 \mathrm{E}+00$ & $0.000 \mathrm{E}+00$ & $0.000 \mathrm{E}+00$ & $0.000 \mathrm{E}+00$ \\
\hline $\mathbf{C O}_{\mathbf{2}}$ & $8.786 \mathrm{E}-05$ & $9.401 \mathrm{E}-05$ & $9.006 \mathrm{E}-05$ & $8.245 \mathrm{E}-05$ \\
\hline $\mathbf{N}_{\mathbf{2}}$ & $4.396 \mathrm{E}-06$ & $4.704 \mathrm{E}-06$ & $4.506 \mathrm{E}-06$ & $4.126 \mathrm{E}-06$ \\
\hline $\mathbf{O}_{\mathbf{2}}$ & $0.000 \mathrm{E}+00$ & $0.000 \mathrm{E}+00$ & $0.000 \mathrm{E}+00$ & $0.000 \mathrm{E}+00$ \\
\hline $\mathbf{A r}$ & $6.281 \mathrm{E}-07$ & $6.720 \mathrm{E}-07$ & $6.438 \mathrm{E}-07$ & $5.894 \mathrm{E}-07$ \\
\hline $\mathbf{H g}$ & $2.586 \mathrm{E}-11$ & $2.767 \mathrm{E}-11$ & $2.651 \mathrm{E}-11$ & $2.427 \mathrm{E}-11$ \\
\hline $\mathbf{H C l}$ & $3.879 \mathrm{E}-07$ & $4.150 \mathrm{E}-07$ & $3.976 \mathrm{E}-07$ & $3.640 \mathrm{E}-07$ \\
\hline
\end{tabular}


Sulfur Containing Gaseous Species Mole Fraction vs Temperature for $\mathrm{LiNO}_{3}$ and a Winkler Off-Gas with $\mathrm{NiO}$ under Reducing Conditions (8.4.2)

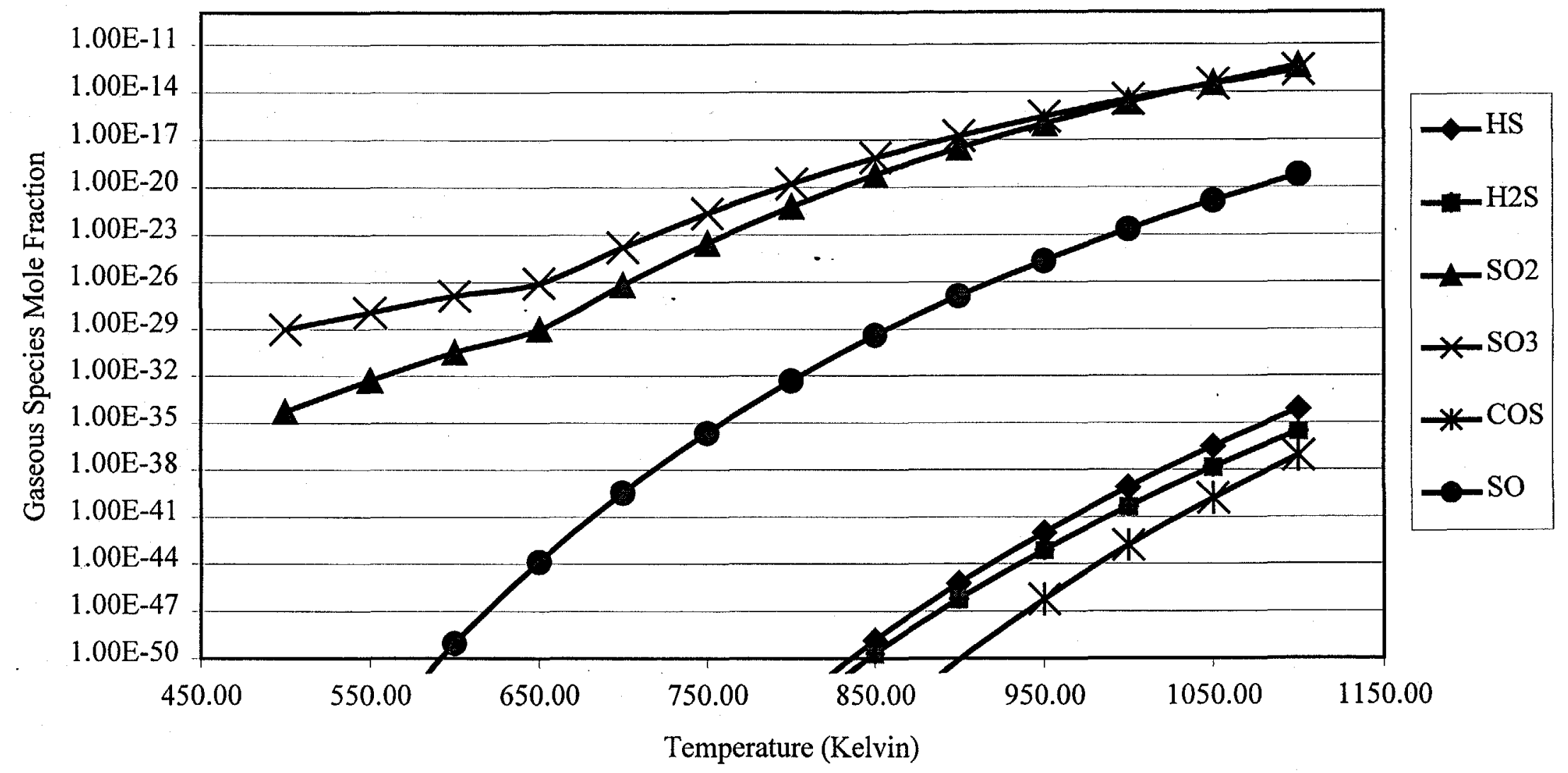

Figure A.51 Sulfur Containing Gaseous Species Mole Fraction for $\mathrm{LiNO}_{3}$ and a Winkler Off-Gas with NiO under Reducing Conditions (8.4.2). 
Sulfur Containing Gaseous Speces Mole Fraction vs Temperature for $\mathrm{NaNO}_{3}$ and a Winkler Off-Gas with $\mathrm{ZrO}_{2}$ under reducing conditions (9.3.2)

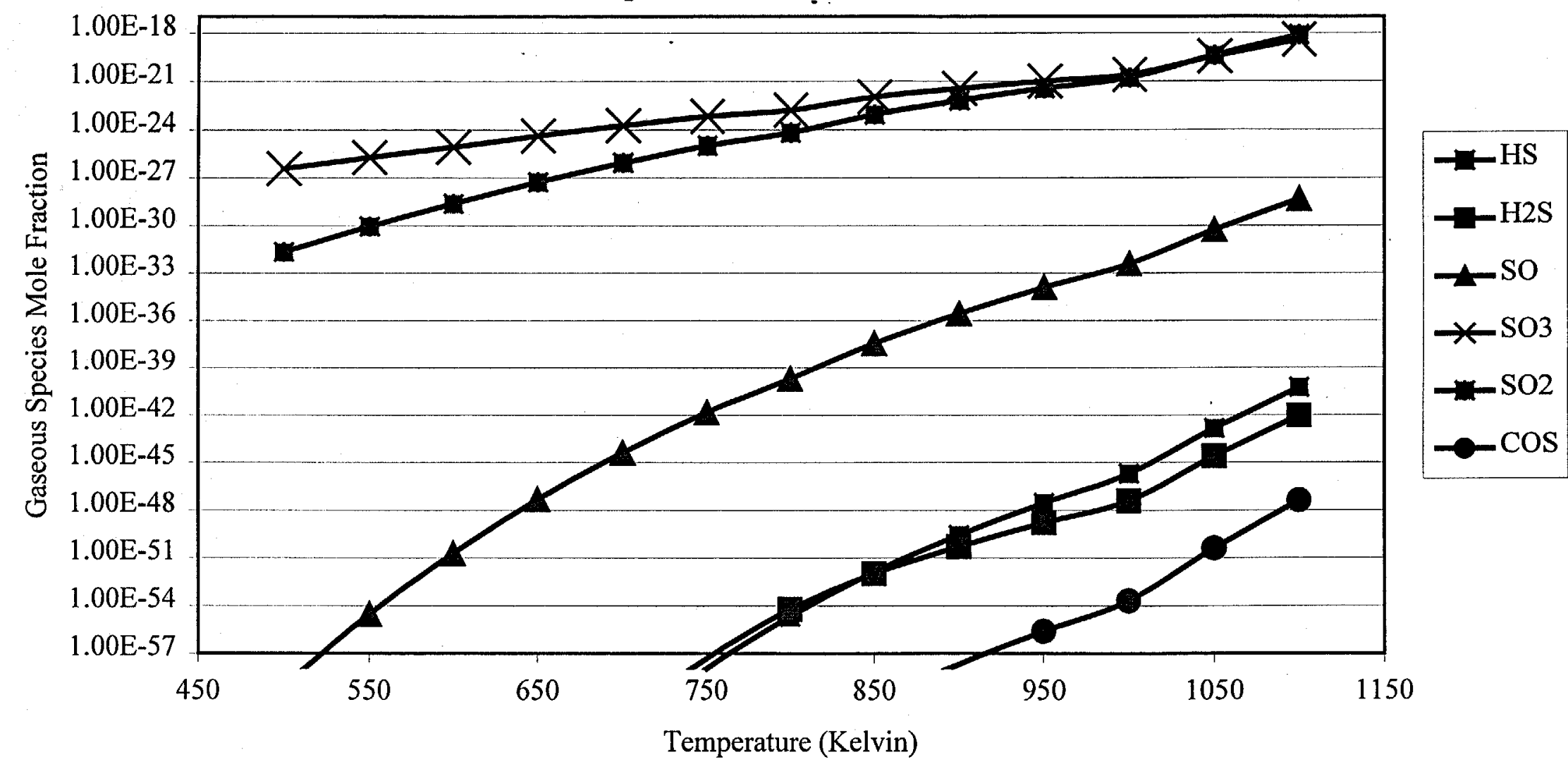

Figure A.52 Sulfur Containing Gaseous Species Mole Fraction for $\mathrm{NaNO}_{3}$ and a Winkler Off-Gas with $\mathrm{ZrO}_{2}$ under Reducing Conditions (9.3.2). 
Sulfur Containing Gaseous Species vs Temperature for $\mathrm{KNO}_{3}$ and a Winkler Gasifier Off-Gas with $\mathrm{ZrO}_{2}$ under Reducing Conditions (10.3.2)

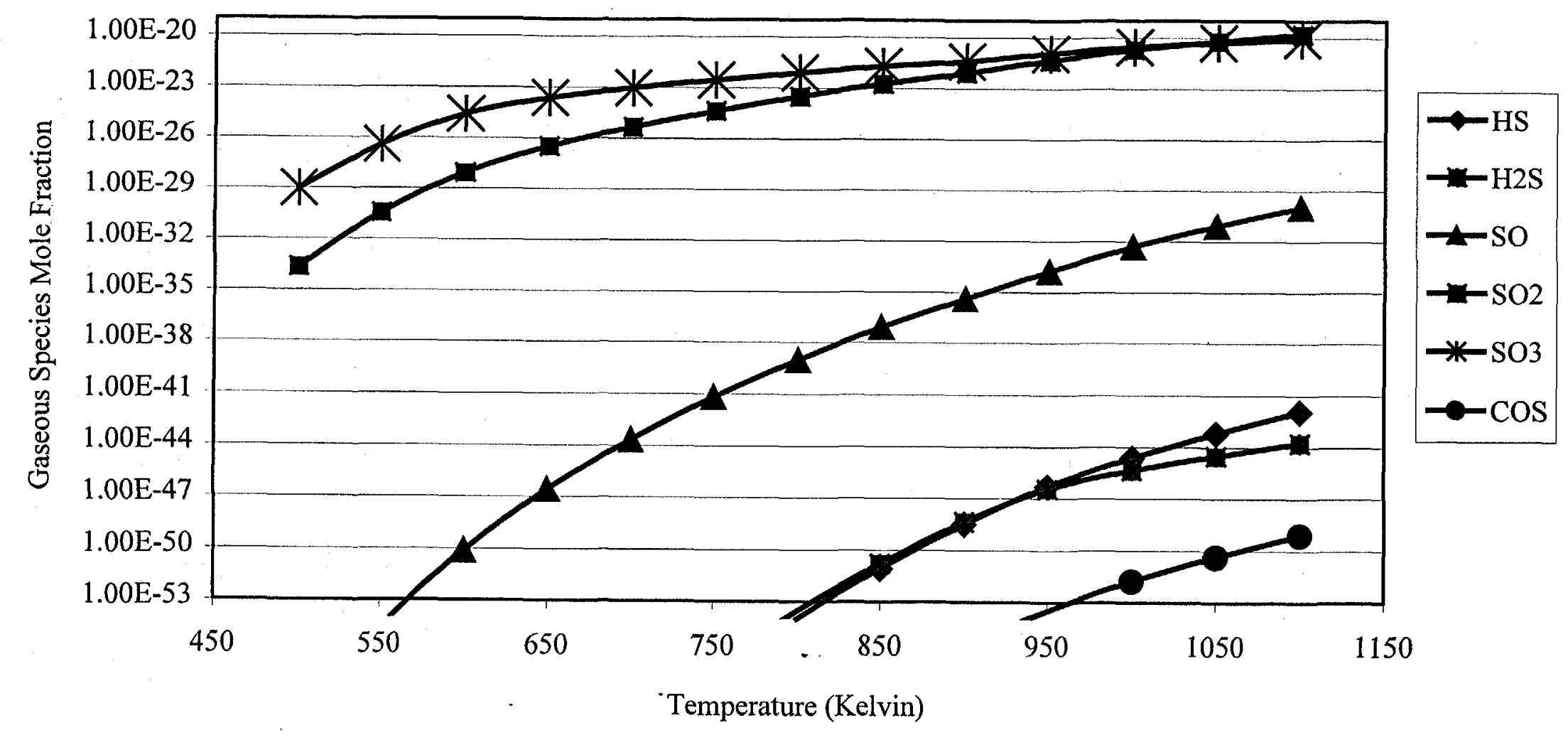

Figure A.53 Sulfur Containing Gaseous Species Mole Fraction for $\mathrm{KNO}_{3}$ and a Winkler Off-Gas with $\mathrm{ZrO}_{2}$ under Reducing Conditions (10.3.2). 
Sulfur Containing Gaseous Species Mole Fraction vs Temperature for $\mathrm{AgNO}_{3}$ and a Winkler Off-Gas with $\mathrm{ZrO}_{2}$ under Reducing Conditions (11.3.2)

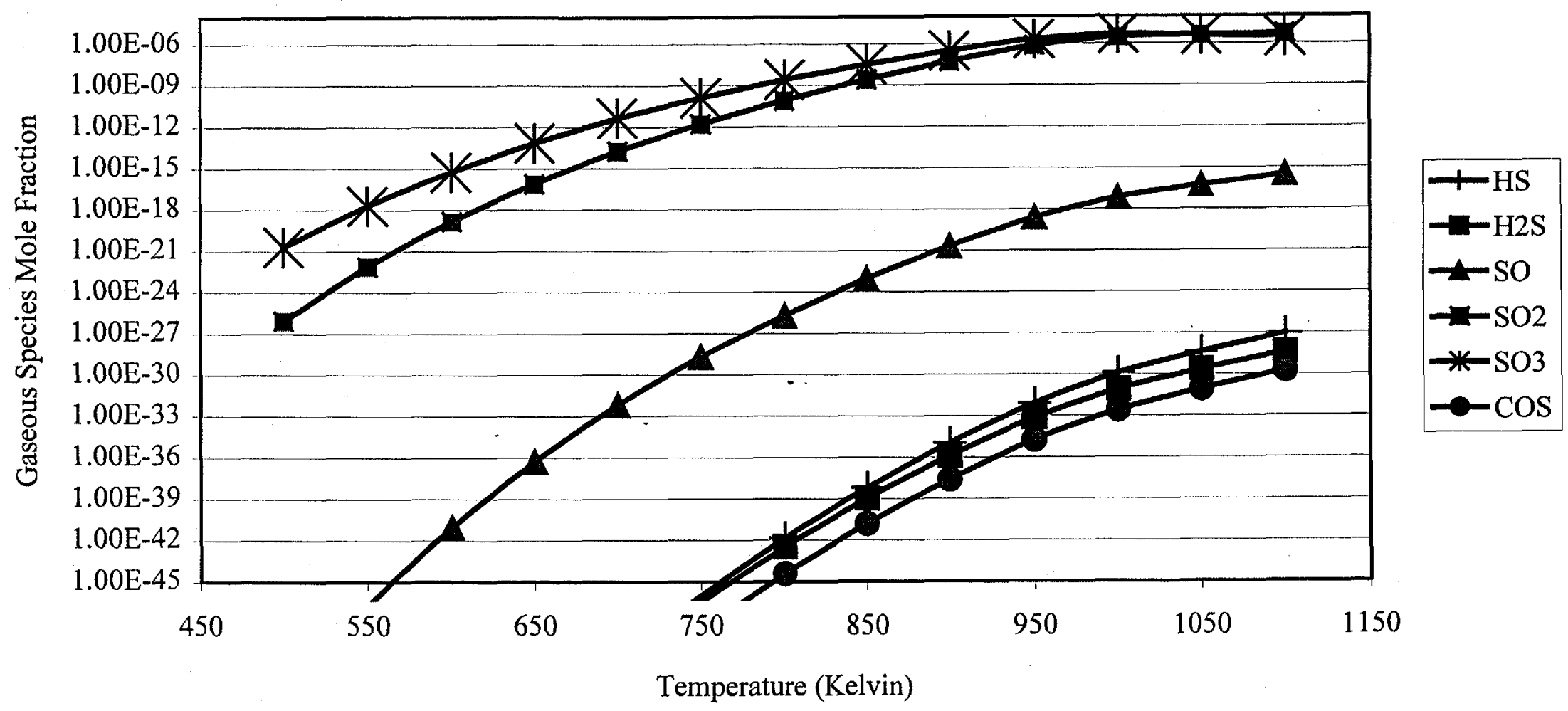

Figure A.54 Sulfur Containing Species Mole Fraction for $\mathrm{AgNO}_{3}$ and a Winkler Off-Gas with $\mathrm{ZrO}_{2}$ under Reducing Conditions (11.3.2). 


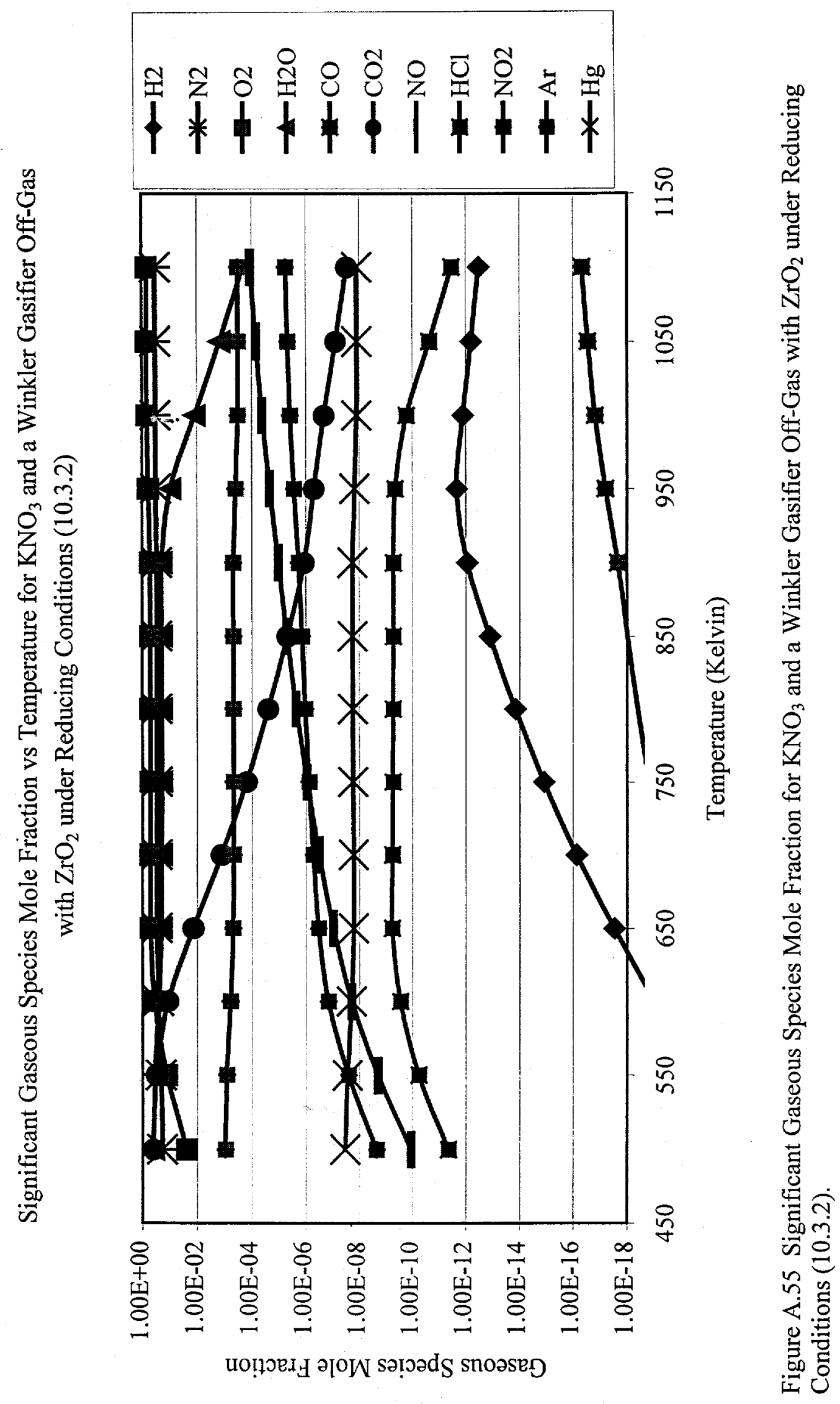


Potassium Gaseous Species Mole Fraction vs Temperature for $\mathrm{KNO}_{3}$ and a Winkler Gasifier Off-Gas with $\mathrm{ZrO}_{2}$ under Reducing Conditions (10.3.2)

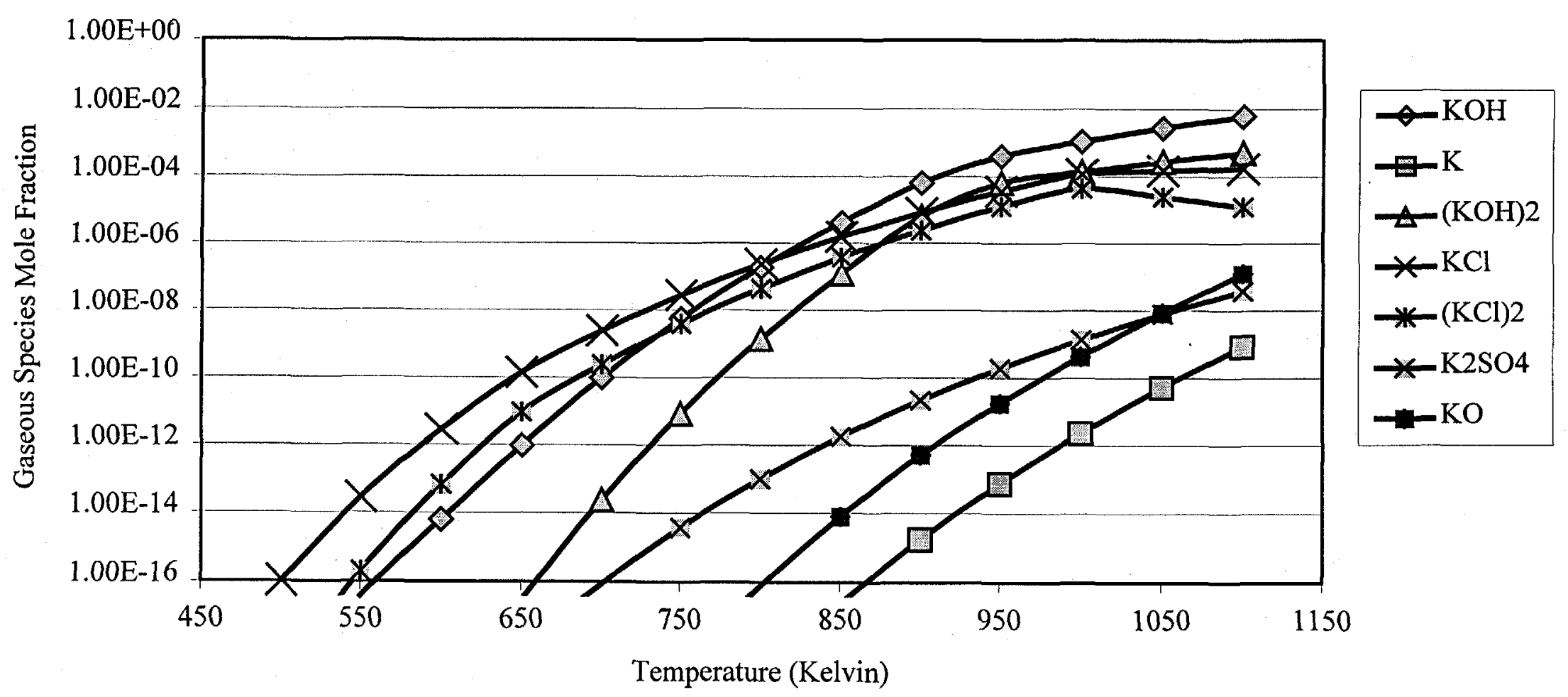

Figure A.56 Potassium Gaseous Species Mole Fraction for $\mathrm{KNO}_{3}$ and a Winkler Gasifier Off-Gas with $\mathrm{ZrO}_{2}$ under Reducing Conditions (10.3.2). 
This section gives the results for systems tested with $\mathrm{KNO}_{3}$ and various supports. Table A.14 lists the reactant molar ratios inputted into FACT. In this section, it turned out there were only three completely stable supports: $\mathrm{ZrO}_{2}, \mathrm{NiO}$, and $\mathrm{Fe}_{2} \mathrm{O}_{3}$. $\mathrm{CaO}$ and $\mathrm{Ca}_{3}\left(\mathrm{PO}_{4}\right)_{2}$ both reacted with the salt over a substantial portion of the temperature range forming very small amounts of $\mathrm{K}_{2} \mathrm{Ca}_{2}\left(\mathrm{CO}_{3}\right)_{3}$ and $\mathrm{K}_{2} \mathrm{HPO}_{4}$, respectively. This type of behavior mirrors that of the systems in the low temperature oxidizing condition section. The amount of gas phase sulfur containing species and $\mathrm{K}_{2} \mathrm{SO}_{4}$ (s) in the partially reactive supports were still the same compared to the completely non-reactive supports. How this small reaction would affect the system's ability to be fluidized is difficult to speculate. There was no appreciable difference between the results obtained for $\mathrm{ZrO}_{2}$ in the previous section and those found when using $\mathrm{NiO}$ and $\mathrm{Fe}_{2} \mathrm{O}_{3}$. This is why no graphs were provided for these systems. Both the low values of the sulfur containing gaseous species and the surprising oxidative behavior were observed with $\mathrm{NiO}$ and $\mathrm{Fe}_{2} \mathrm{O}_{3}$.

It is entirely possible that when kinetics are taken into account for these systems that the $\mathrm{CO}$ and $\mathrm{H}_{2}$ are not oxidized. Further study using the FACT React program, literature searches, and empirical studies is needed to truly determine whether this type of system is of any practical use in conjunction with a molten carbonate fuel cell. 
Table A.14 FACT entering Molar Ratios for $\mathrm{KNO}_{3}$ and a Winkler Off-Gas with various Supports under Low Temperature Reducing Conditions.

\begin{tabular}{|c|c|c|c|c|}
\hline & $(10.1 .2)$ & $(10.2 .2)$ & $(10.4 .2)$ & $(10.5 .2)$ \\
\hline Support & $1.000 \mathrm{E}+00$ & $1.000 \mathrm{E}+00$ & $1.000 \mathrm{E}+00$ & $1.000 \mathrm{E}+00$ \\
\hline Salt & 6.603E-02 & 1.121E-01 & 8.209E-02 & $1.755 \mathrm{E}-01$ \\
\hline $\mathrm{CO}$ & $2.593 \mathrm{E}-04$ & 2.788E-04 & 2.658E-04 & 3.099E-04 \\
\hline $\mathbf{C H}_{4}$ & 8.642E-06 & 9.295E-06 & 8.861E-06 & $1.033 \mathrm{E}-05$ \\
\hline $\mathbf{H}_{2}$ & $2.215 \mathrm{E}-04$ & 2.383E-04 & 2.271E-04 & $2.648 \mathrm{E}-04$ \\
\hline $\mathrm{COS}$ & 2.881E-07 & 3.098E-07 & 2.954E-07 & $3.444 \mathrm{E}-07$ \\
\hline $\mathrm{H}_{2} \mathrm{~S}$ & 8.642E-07 & $9.295 \mathrm{E}-07$ & 8.861E-07 & $1.033 \mathrm{E}-06$ \\
\hline $\mathrm{NH}_{3}$ & $0.000 \mathrm{E}+00$ & $0.000 \mathrm{E}+00$ & $0.000 \mathrm{E}+00$ & $0.000 \mathrm{E}+00$ \\
\hline $\mathrm{CO}_{2}$ & 8.060E-05 & $8.669 \mathrm{E}-05$ & $8.265 \mathrm{E}-05$ & $9.635 \mathrm{E}-05$ \\
\hline $\mathbf{N}_{2}$ & 4.033E-06 & $4.338 \mathrm{E}-06$ & $4.135 \mathrm{E}-06$ & $4.821 \mathrm{E}-06$ \\
\hline $\mathbf{O}_{2}$ & $0.000 \mathrm{E}+00$ & $0.000 \mathrm{E}+00$ & $0.000 \mathrm{E}+00$ & $0.000 \mathrm{E}+00$ \\
\hline Ar & $5.761 \mathrm{E}-07$ & $6.196 \mathrm{E}-07$ & $5.908 \mathrm{E}-07$ & $6.887 \mathrm{E}-07$ \\
\hline $\mathbf{H g}$ & $2.372 \mathrm{E}-11$ & $2.551 \mathrm{E}-11$ & $2.432 \mathrm{E}-11$ & $2.836 \mathrm{E}-11$ \\
\hline \multirow[t]{2}{*}{$\mathbf{H C l}$} & 3.558E-07 & 3.827E-07 & 3.649E-07 & 4.254E-07 \\
\hline & $(10.6 .2)$ & $(10.7 .2)$ & $(10.8 .2)$ & $(10.9 .2)$ \\
\hline Support & $1.000 \mathrm{E}+00$ & $1.000 \mathrm{E}+00$ & $1.000 \mathrm{E}+00$ & $1.000 \mathrm{E}+00$ \\
\hline Salt & $2.153 \mathrm{E}-01$ & $8.779 \mathrm{E}-02$ & $6.162 \mathrm{E}-02$ & $3.409 \mathrm{E}-01$ \\
\hline $\mathrm{CO}$ & $3.323 \mathrm{E}-04$ & $2.682 \mathrm{E}-04$ & $2.575 \mathrm{E}-04$ & $4.230 \mathrm{E}-04$ \\
\hline $\mathrm{CH}_{4}$ & $1.108 \mathrm{E}-05$ & 8.941E-06 & 8.583E-06 & $1.410 \mathrm{E}-05$ \\
\hline $\mathrm{H}_{2}$ & $2.839 \mathrm{E}-04$ & $2.292 \mathrm{E}-04$ & $2.200 \mathrm{E}-04$ & $3.614 \mathrm{E}-04$ \\
\hline $\mathrm{COS}$ & $3.692 \mathrm{E}-07$ & $2.980 \mathrm{E}-07$ & $2.861 \mathrm{E}-07$ & $4.700 \mathrm{E}-07$ \\
\hline $\mathrm{H}_{2} \mathrm{~S}$ & $1.108 \mathrm{E}-06$ & $8.941 \mathrm{E}-07$ & $8.583 \mathrm{E}-07$ & $1.410 \mathrm{E}-06$ \\
\hline $\mathbf{N H}_{3}$ & $0.000 \mathrm{E}+00$ & $0.000 \mathrm{E}+00$ & $0.000 \mathrm{E}+00$ & $0.000 \mathrm{E}+00$ \\
\hline $\mathrm{CO}_{2}$ & $1.033 \mathrm{E}-04$ & $8.339 \mathrm{E}-05$ & $8.005 \mathrm{E}-05$ & $1.315 \mathrm{E}-04$ \\
\hline $\mathbf{N _ { 2 }}$ & $5.169 \mathrm{E}-06$ & $4.173 \mathrm{E}-06$ & $4.006 \mathrm{E}-06$ & $6.580 \mathrm{E}-06$ \\
\hline $\mathbf{O}_{2}$ & $0.000 \mathrm{E}+00$ & $0.000 \mathrm{E}+00$ & $0.000 \mathrm{E}+00$ & $0.000 \mathrm{E}+00$ \\
\hline $\mathbf{A r}$ & $7.384 \mathrm{E}-07$ & $5.961 \mathrm{E}-07$ & $5.722 \mathrm{E}-07$ & 9.400E-07 \\
\hline $\mathbf{H g}$ & $3.040 \mathrm{E}-11$ & $2.454 \mathrm{E}-11$ & $2.356 \mathrm{E}-11$ & $3.871 \mathrm{E}-11$ \\
\hline $\mathrm{HCl}$ & $4.561 \mathrm{E}-07$ & $3.682 \mathrm{E}-07$ & $3.534 \mathrm{E}-07$ & $5.806 \mathrm{E}-07$ \\
\hline
\end{tabular}




\section{Appendix B: Experimental Procedures and Results}

This appendix focuses on the experimental procedures and equipment used to study fluidization characteristics during salt loading experiments. Two different fluidized beds were used to complete the experiments. The first fluidized bed was made out of alumina and designed by Pete Czerpak (M.S. 1998) to study alumina and silica particles in the 100-250 micron size range. A brief description of this first generation system is given below. The second generation fluidized bed was made out of Inconel ${ }^{\mathrm{TM}}$, and designed to uniformly fluidize 500-micron silica glass ballotini.

The primary component used in both the generation I and II systems is a Thermal Technology Astro laboratory furnace designed to provide a $0.46 \mathrm{~m}(1.51 \mathrm{ft})$ hot zone with a $0.11 \mathrm{~m}\left(4.3^{\prime \prime}\right)$ internal diameter (ID). The furnace itself is capable of reaching temperatures upward of $2300^{\circ} \mathrm{C}\left(4772^{\circ} \mathrm{F}\right)$. A Eurotherm Controls EPC Controller controls the furnace element temperature. The temperature is measured with a pneumatically controlled retractable thermocouple up to $1100^{\circ} \mathrm{C}\left(2012^{\circ} \mathrm{F}\right)$ and then a dual wavelength optical pyrometer measures temperatures higher than $1100^{\circ} \mathrm{C}$ $\left(2012^{\circ} \mathrm{F}\right)$. A Honeywell Limit Control Module monitors the maximum temperature allowable for the equipment and can affect process shutdown. The reactor is cooled using house water at a flow rate greater than $17 \mathrm{Lpm}(4.5 \mathrm{gpm})$. The graphite element is isolated from the centerline of the furnace with a $9.21 \mathrm{~cm}(3.625$ ") ID alumina muffle tube.

\section{B.1) Generation I Process Description}

The Generation I process schematic is given in Figure B.1. The Generation I Process used an alumina fluidized bed reactor made by Coors Ceramic $\mathrm{Co}$. The fluidized bed consisted of two alumina tubes approximately $6.79 \mathrm{~cm}\left(2.675^{\prime \prime}\right)$ ID and extended the length of the furnace's hot zone. The distributor plate was made out of $0.3 \mathrm{~cm}(.11$ ") thick alumina with 18-0.01 $\mathrm{cm}\left(0.039^{\prime}\right)$ holes. Peter Czerpak completed the distributor plate deston and Coors Ceramic Co made the distributor plate.(Czerpak 1998). A schematic for the fluidized bed is shown in Figure B.2. The distributor plate was permanently secured between the two alumina reactor tubes with a larger diameter alumina coupling tube and Aremco Ceramabound 503 ceramic cement. Nitrogen acted as the fluidizing gas and the inert sweep gas to protect the graphite element. Nitrogen was supplied from a large liquid nitrogen dewer. If the large dewer's pressure dropped below $2.76 \mathrm{E} 5 \mathrm{~Pa}(40 \mathrm{psig}$ ), nitrogen from a high-pressure gaseous nitrogen cylinder began flowing. Three Brooks Flowmeters with varying capacities controlled the flow of nitrogen to the fluidized bed. Two Dwyer flowmeters delivered sweep gas to the element chamber and sight glass windows.

All gas supplied to the furnace and fluidized bed was vented to the laboratory hood via $0.635 \mathrm{~cm}(0.25$ ") stainless steel tubing to accommodate the high temperature gases from the fluidized bed. The nitrogen was filtered $\mathrm{b}$ a microfilter (Balston Model 82-700-BX) to remove any fine particles prior to entering the flowmeters. The process gas was also filtered after leaving the fluidized bed. The fine particles were removed to prevent clogging in the $0.635 \mathrm{~cm}(0.25$ ") stainless tubing on the way to the hood. 


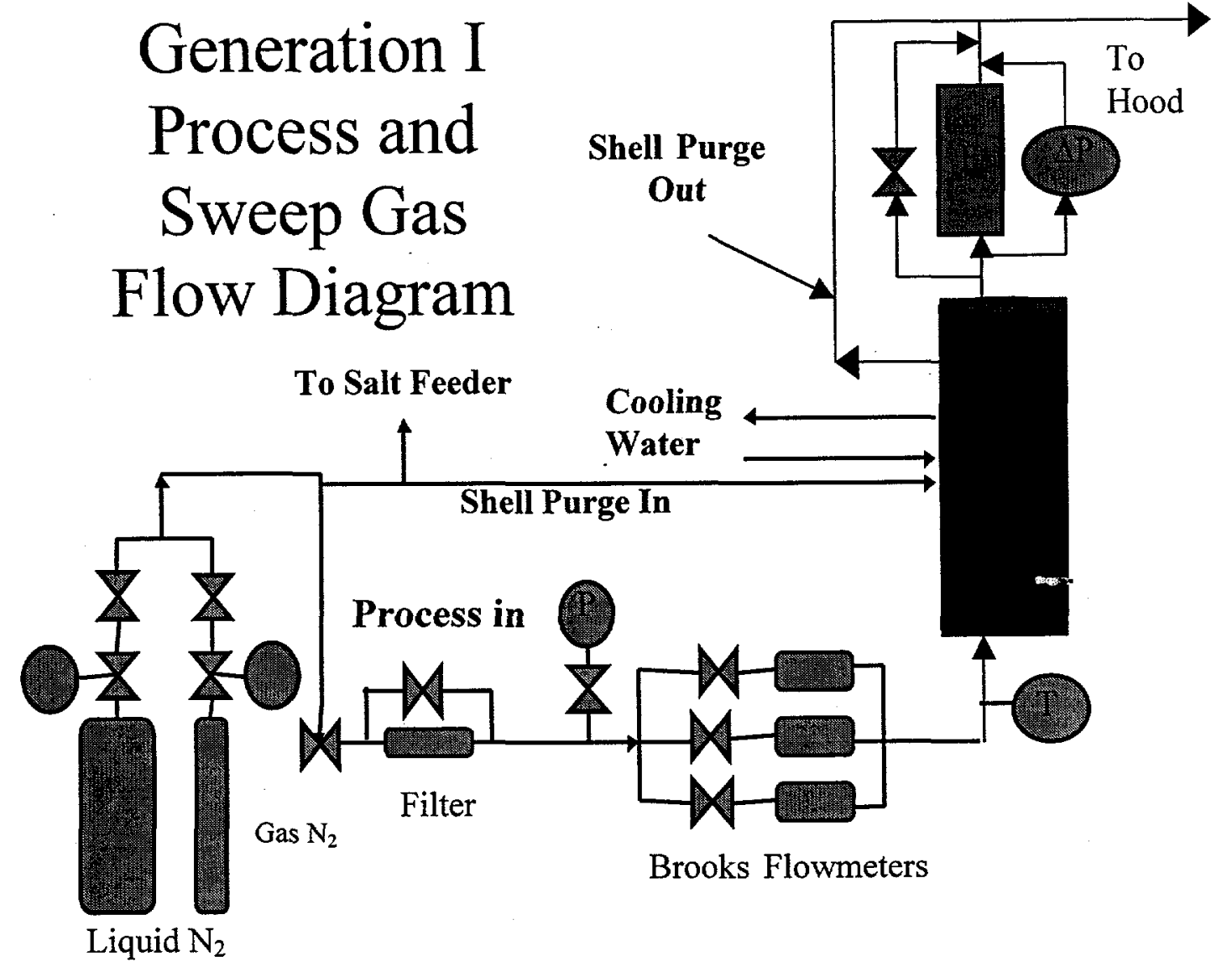

Figure B.1 Generation I Process and Sweep Gas Flow Diagram. 


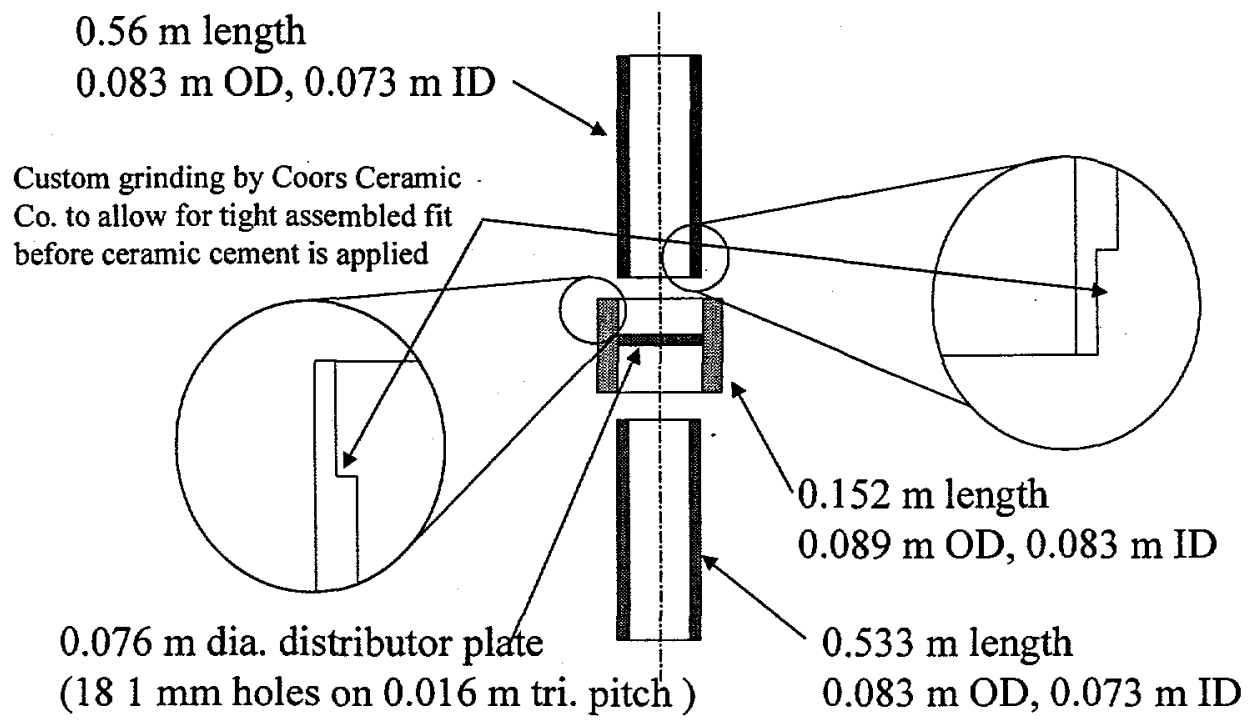

Figure B.2 Generation I Fluidized Bed Reactor Schematic. 
The temperature in the bed was measured with an Omega Sciences type K, ungrounded, Inconel ${ }^{\mathrm{TM}}$ sheathed, closed-tip thermocouple. The thermocouple enters the reactor through a Swagelock $0.635 \mathrm{~cm}\left(0.25^{\prime \prime}\right)$ tube fitting connection located in the top furnace plate and extended down into the fluidized bed, position just above the distributor plate. The temperature of the gas entering the fluidized bed was measured along with the inlet pressure for use in calculating the correct volumetric flow rate. The inlet pressure was measured using another Validyne DP-15 pressure transducer. The volumetric flow rate and superficial velocity through the fluidized bed were calculated.

The pressure drop across the fluidized bed is the critical measurement for understanding the particles' fluidization characteristics. The $\triangle \mathrm{P}$ was measured by first inserting an uncapped $0.635 \mathrm{~cm}\left(0.25^{\prime \prime}\right)$ stainless steel tube through the top reactor plate to the bottom of the particle. The pressure above the bed was measured with an uncapped, $0.32 \mathrm{~cm}\left(0.125^{\prime \prime}\right)$ stainless steel tube, which also passed through the top reactor plate. The tube opening for the low-pressure measurement is located at the top of the fluidized bed reactor as seen in Figure B.3. Considering the importance of the pressure drop measurement, two different measuring devices were used to determine the pressure drop. A Validyne DP-15 pressure transducer (PTDR\# 1) was used in conjunction with a Dwyer Magnehelic 0-2.5E3 $\mathrm{Pa}\left(0-10\right.$ " of $\left.\mathrm{H}_{2} \mathrm{O}\right)$ low pressure gauge. The gauge pressure in the reactor above the distributor plate was measured with a Dwyer Magnehelic 0-1.25E4 $\mathrm{Pa}\left(0-50\right.$ " of $\left.\mathrm{H}_{2} \mathrm{O}\right)$ low pressure gauge. 


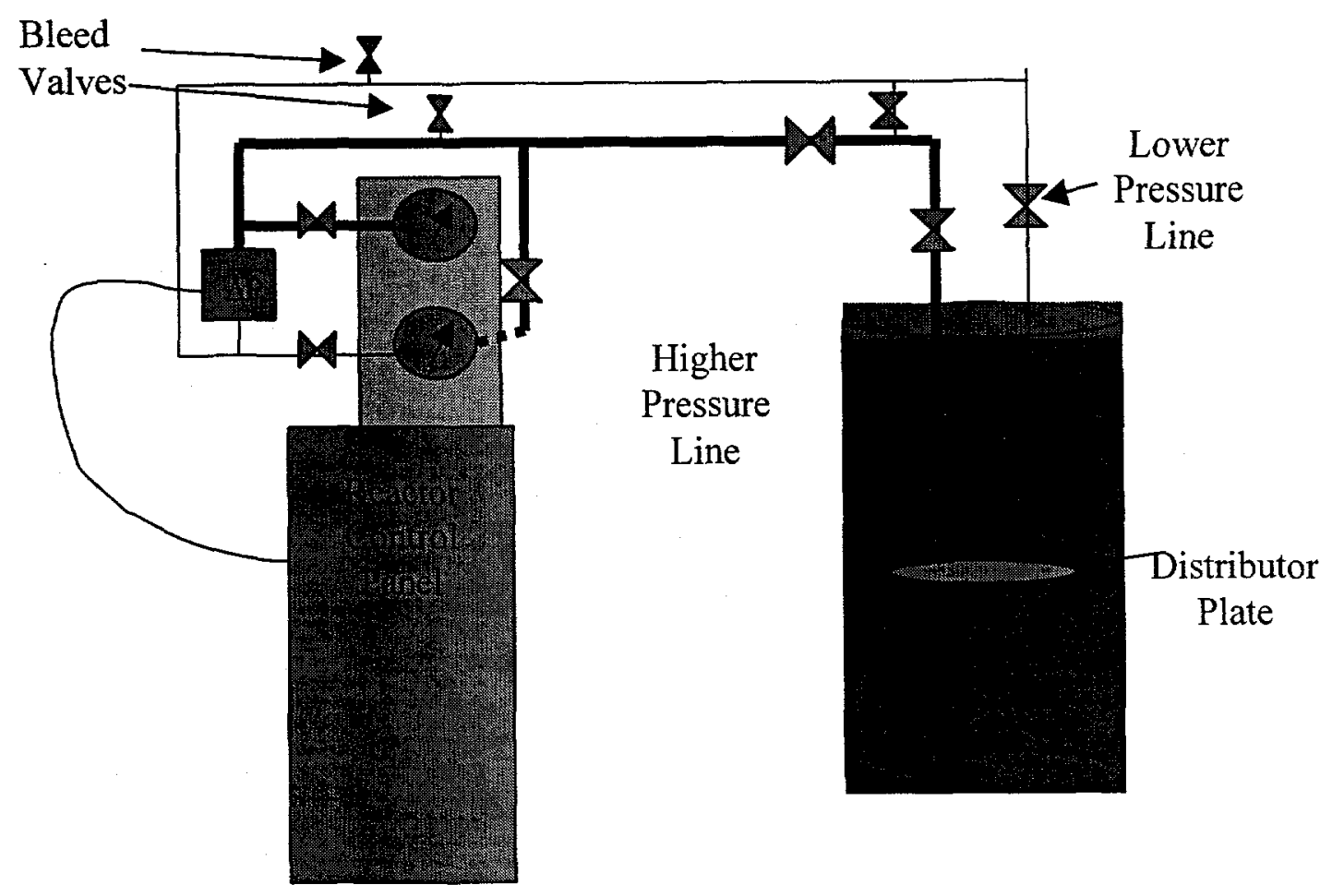

Figure B.3 Generation I Pressure Drop Measuring System.

Figure B.4 Salt Injector Schematic.

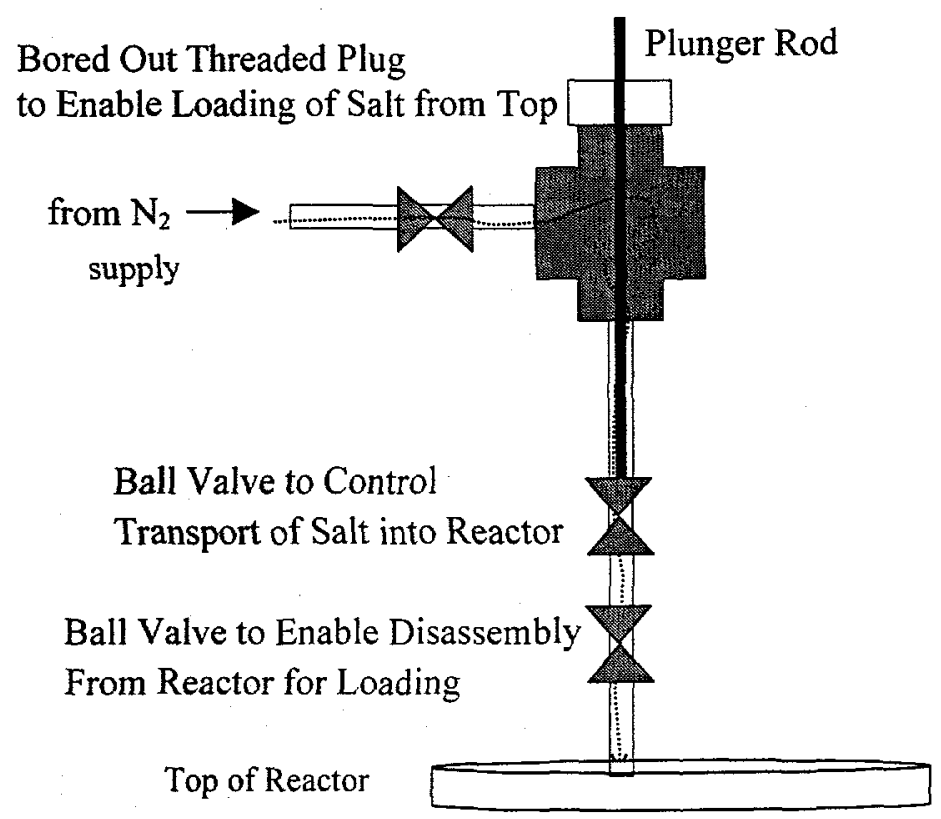


The salt was injected into the fluidized bed reactor through the top reactor plate. The pneumatic salt feeder seen in Figure B.4 used compressed $\mathrm{N}_{2}$ from the gaseous $\mathrm{N}_{2}$ cylinder. When the salt feeder was in use the gaseous $\mathrm{N}_{2}$ tank was isolated from the process flow nitrogen to prevent disrupting the flow through the fluidized bed reactor. The salt feeder was connected to the gaseous nitrogen line with flexible stainless steel tubing. The plunger rod was made from an old coat hanger and inserted into the feeder through a $0.32 \mathrm{~cm}(0.125$ ") Swagelock $®$ tube fitting. The feeder itself is $0.95 \mathrm{~cm}\left(0.375^{\prime \prime}\right)$ stainless steel tubing with two Swagelock $\$$ ball valves. The $0.95 \mathrm{~cm}\left(0.375^{\prime \prime}\right)$ tubing enters the reactor through another Swagelock ${ }^{\circledR}$ tube fitting. The salt feeder extends down into the reactor where the salt is released approximately $1.5 \mathrm{~cm}\left(6^{\prime \prime}\right)$ above the surface of the bed.

\section{B.2) Generation II Process Description}

A number of changes were made to the Generation I set up to accommodate larger particle sizes. A new fluidized bed reactor was designed out of an $8.9 \mathrm{~cm}$ (3.5") O.D. Inconel ${ }^{\mathrm{TM}}$ tube. In the Generation II system, compressed air is used as the fluidizing gas. Figure B.5 shows the new process and sweep gas flow schematic. There are a number of changes that deserve mentioning.

First, a fourth Brooks Flowmeter was installed to handle the larger volumetric flow rates of gas needed to fluidize larger particles. The piping from the house compressed air line is $0.635 \mathrm{~cm}\left(0.25^{\prime \prime}\right)$ galvanized steel with a series of brass 0.635 $\mathrm{cm}(0.25$ ") ball values to control the flow. A regulator controls the compressed air's pressure, which is typically set between $4.46-4.84 \mathrm{E} 5 \mathrm{~Pa}$ (65-70 psig). The compressed air flows through Parker coalescing and adsorbing filters, each with an auto drain. The gas' pressure is still measured after leaving the flowmeters with a Validyne DP-15 pressure transducer referred to as PTDR \#2. The air leaving the flowmeter enters $0.635 \mathrm{~cm}\left(0.25^{\prime \prime}\right)$ galvanized steel tubing before entering $0.6 \mathrm{~m}(2$ ') of $1.59 \mathrm{~cm}\left(0.675^{\prime \prime}\right)$ I.D. Tygon tubing which is attached to the furnace bottom plate with a hose clamp and tubing nipple. Thin walled $1.25 \mathrm{~cm}(0.5$ ") O.D. stainless steel tubing transports the post reactor gas to the hood. A Filterite porous metal filter made by the Memtec of America Corporation filters the compressed air on the way to the hood. Another Validyne pressure transducer measures the pressure drop across the filter. This pressure transducer is referred to as PTDR \#3.

The Inconel ${ }^{\mathrm{TM}}$ fluidized bed reactor is $114.3 \mathrm{~cm}$ (43") long with a $7.62 \mathrm{~cm}$ (3.0") ID. The distributor plate is made out of 304 Stainless Steel, and has a $7.87 \mathrm{~cm}$ (3.1") diameter and $0.127 \mathrm{~cm}(0.05$ ") thickness. The distributor plate was welded into the Inconel ${ }^{\mathrm{TM}}$. The distributor plate has approximately 70 holes, each $0.05 \mathrm{~cm}$ $\left(0.020^{\prime \prime}\right)$ in diameter, arranged in a $0.8 \mathrm{~cm}(0.32)$ triangular pitch pattern. 


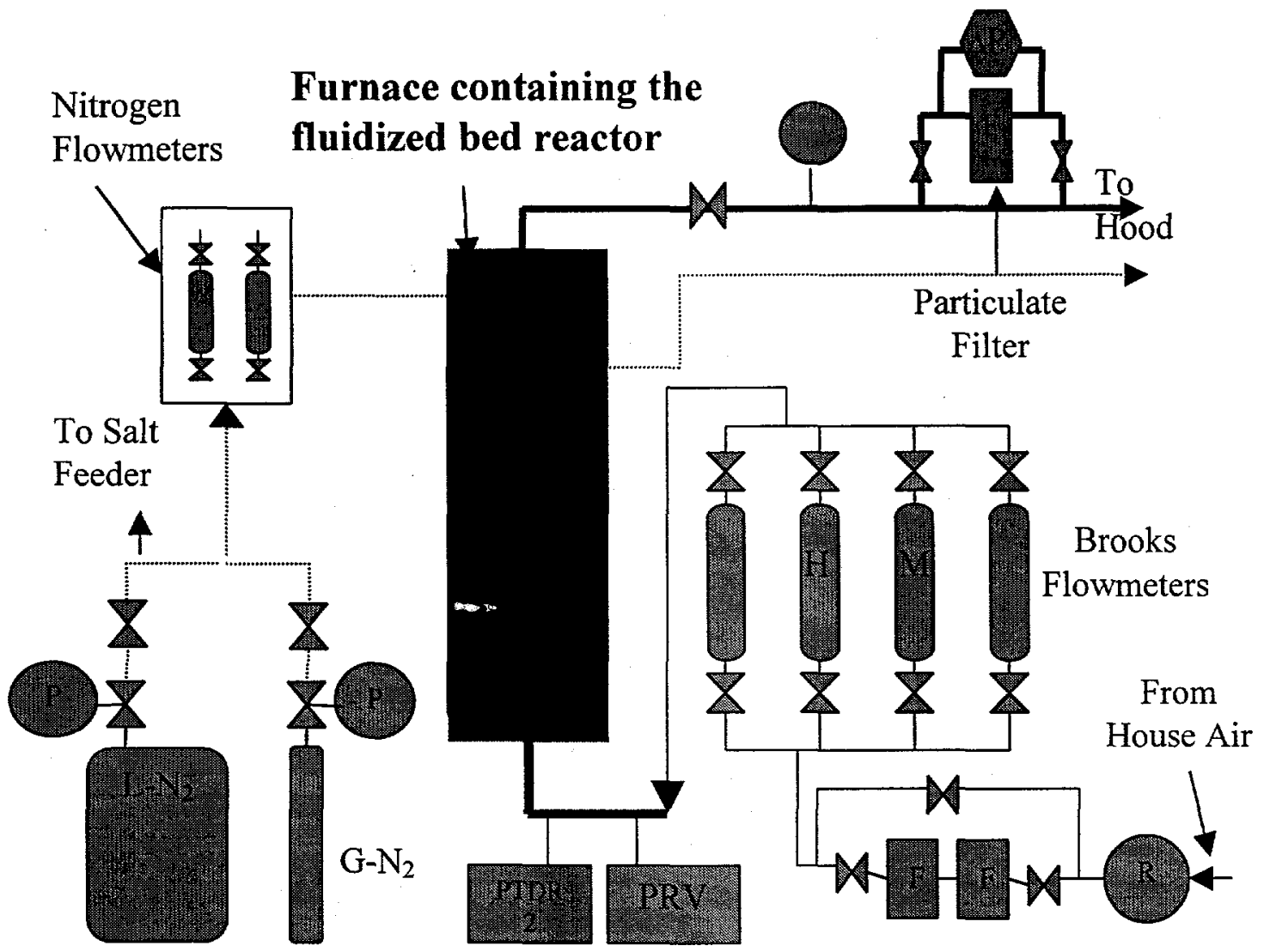

Figure B.5 Generation II Process and Sweep Gas Flow Diagram. 
The inert sweep gas is still nitrogen and is supplied from the same source previously mentioned for the Generation I system. There are three main differences in the piping set up for the nitrogen. All of these changes were made to reduce the risk of compressed air entering the graphite element chamber. First, the $0.635 \mathrm{~cm}$ $\left(0.25^{\prime \prime}\right)$ stainless steel tubing that connected the sweep and process flow in the Generation I setup was removed and capped in order to completely separate the compressed air lines from the nitrogen lines. Next, the sweep gas was given its own vent line to the hood made out the $0.635 \mathrm{~cm}(0.25$ ") stainless steel. Finally, the Tygon tubing line that carried nitrogen to the top plate reactor sight window was removed and capped. Removing this line prevented the compressed air flowing through the fluidized bed from flowing back through the nitrogen line and contaminating the graphite element chamber.

A couple of changes were made to the pressure drop measuring system as seen in Figure B.6. Two in-line filters were installed to prevent the support from traveling ap the stainless steel tubing and contaminating the pressure transducer (PTDR\#1) and pressure gauges. This is only an issue if a valve happens to be turned the wrong way at an in-opportune moment. An additional, 0.635 (0.25") stainless steel tube was inserted through the bottom reactor plate for a number of reasons. The additional tube, which opens a couple of centimeters below the distributor plate, measures the pressure of the gas entering the reactor. The stainless steel tube that measures the pressure above the distributor plate was capped and12-1 $\mathrm{mm}$ holes were drilled equidistant around the outer circumference to reduce clogging.

The final set of experiments used a different method for introducing the salt into the fluidized bed reactor. The method used water as the vehicle for salt transport into the reactor. The aqueous salt solution was injected from a syringe through 0.32 $\mathrm{cm}(0.125$ ") stainless steel tubing down into the reactor. The water would flash-off and the salt would in theory be left in an even coating on the particles. See Figure B.7 for a schematic. 


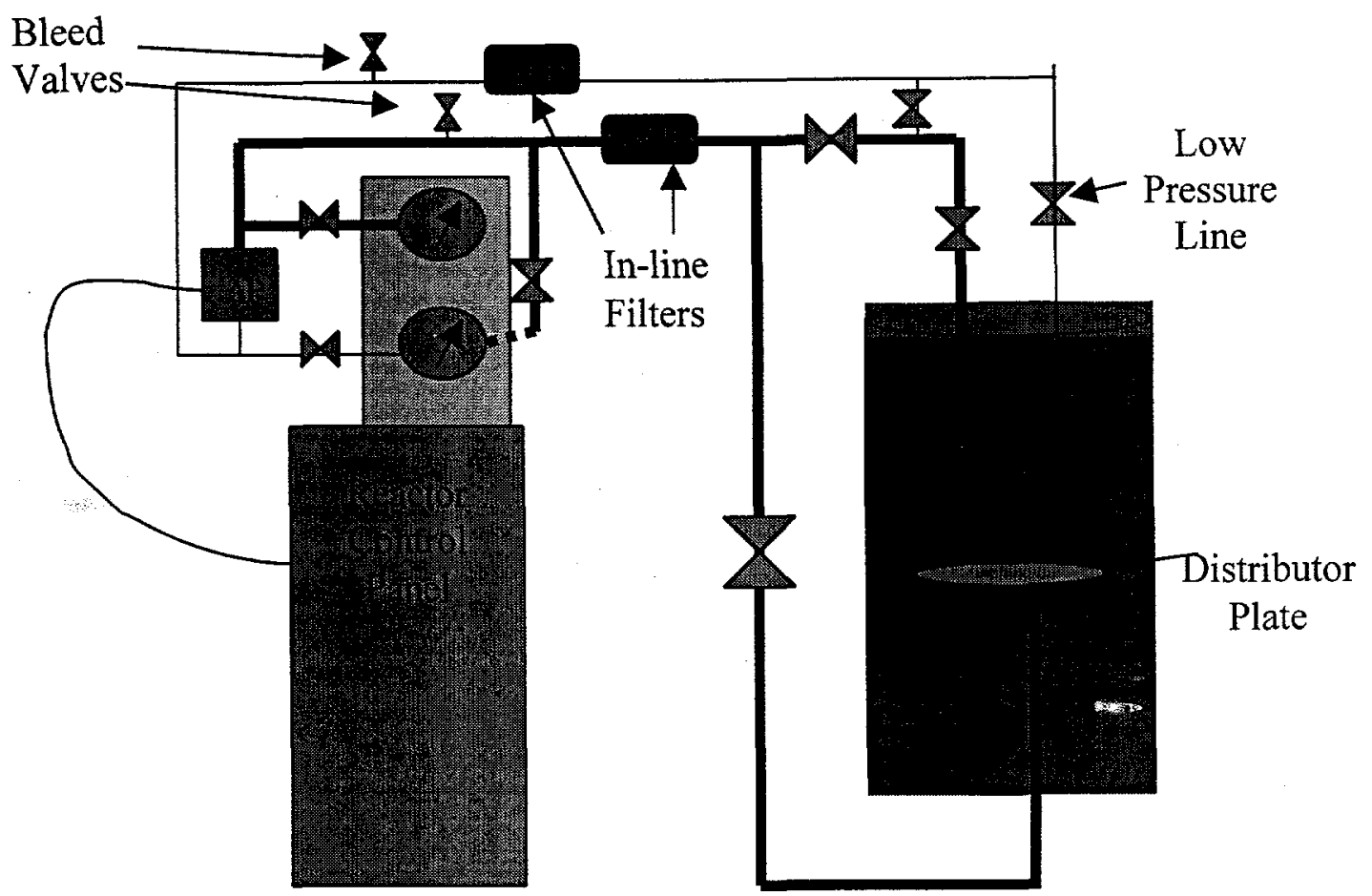

Figure B.6 Generation II Pressure Drop Measurement.

Figure B.7 Aqueous Salt Injection System.

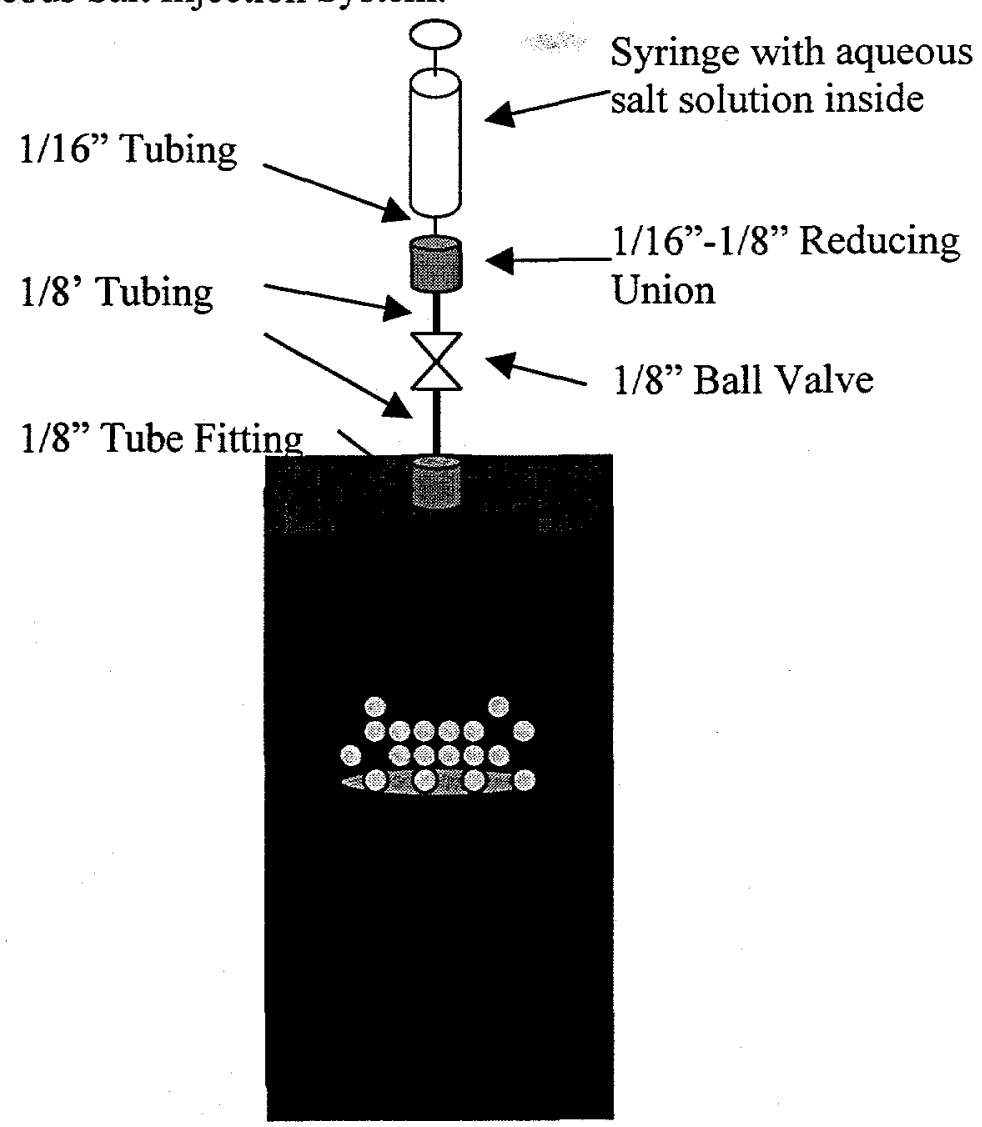




\section{B.3) Generation I Data Collection Procedures/Results}

In this section, two supports were tested to ascertain their salt loading capability. The two supports explored were U.S. Silica F-110 and L-60 whose important characteristics are listed in Table B.1. One goal centered on achieving complete fluidization of the support material. In previous experiments completed using these supports, the pressure drop measured for a bed mass of $350 \mathrm{gm}$ and a reactor diameter of $6.8 \mathrm{~cm}$ (2.675") was consistently $30-40 \%$ below the theoretical $\Delta \mathrm{P}$. The theoretical value for a pressure drop across a fluidized bed at the point of minimum fluidization is calculated by dividing the weight of the support material by the cross sectional area of the reactor tube (Kunii and Levenspiel 1991). The theoretical pressure drop for these supports should have been $897 \mathrm{~Pa}$ (3.6 inches of $\mathrm{H}_{2} \mathrm{O}$ ) based on this postulate. Presumably, the lower pressure drop across the bed of particles was caused by incomplete fluidization of the support particles.

A Dwyer Magnehelic Gauge (0-2.49E3) $\mathrm{Pa}\left((0-10)\right.$ " of $\left.\mathrm{H}_{2} \mathrm{O}\right)$ was used in conjunction with the Validyne pressure transducer (PTDR\#1) to provide additional confidence that the measurements were accurate. 
Table B.1 Support Material Properties.

\begin{tabular}{|c|c|c|c|}
\hline Designation & Supplier & Avg $\mathrm{d}_{\mathrm{p}}$ & Loose Bulk Density \\
\hline & & $(\mu \mathrm{m})$ & $\left(\mathrm{gm} / \mathrm{cm}^{3}\right)$ \\
\hline F-110 & US Silica & 110 & 1.55 \\
\hline L-60 & US Silica & 227 & 1.48 \\
\hline
\end{tabular}


The method in which the pressure drop measurement was determined is different from previous experiments for the Generation I fluidized bed. Previous experiments measured the nitrogen's pressure prior to entering the furnace and then after it left the furnace. Figure B.8 shows how this was accomplished. In order to use this method, the pressure drop across the distributor plate, as a function of the gas flow rate and temperature, must be determined. In addition to that correction, the pressure drop across the large $5 \mathrm{~mm}$ alumina particles also needs to be known as a function of the gas flow rate and temperature. The $5 \mathrm{~mm}$ alumina particles just mentioned prevented the much smaller support particles from falling through the distributor plate and aided in uniformly distributing the gas flow through the fluidized particles. The pressure drop across the bed of fluidized particles is easily determined if these two quantities are known. The problem with using this method is that there is an error associated with each measurement taken to obtain the pressure drop across the distributor plate and the bed of stationary particles. Measuring the pressure drop from the bottom of the fluidized particles and then at some height above the bed is a preferred method. This method was adopted for Generation II and I experiments. A visual schematic for this method is found in Figures B.3 and B.5.

\section{B.3a) Minimum Fluidization Curve Procedure}

Approximately $500 \mathrm{gm}$ of the $5 \mathrm{~mm} \mathrm{Al}_{2} \mathrm{O}_{3}$ spheres were initially loaded into the fluidized bed reactor through the top slight glass window. Nitrogen flow was initiated through the bed to prevent the smaller material from falling down through the large particles. Next 350 grams of the designated support material was loaded into the bed. In order to understand the molten salt's affect on the interparticle forces between the particles, a baseline for a system where the interparticle forces are assumed to be negligible was established. This is one of the reasons minimum fluidization curves for the various support materials were determined prior to adding salt to the bed

To obtain the minimum fluidization curves, the volumetric flow was increased to well above the minimum fluidization point. The velocity at which the pressure drop no longer substantially increases with increased flow rate signifies the minimum fluidization point (Kunii and Levenspiel 1991). The flow rate was slowly decreased and the pressure drop readings from both pressure transducers and pressure gauges were recorded along with the corresponding flow rate. The flow rate was decreased well past the point of minimum fluidization, but care was taken not to decrease the flow to the point that the particles began to fall through the distributor plate. The flow rate was then increased to see if a specific flow rate produces the same pressure drop. Initially, runs were completed to obtain the minimum fluidization curve for $\mathrm{F}$ 110 with the large $\mathrm{Al}_{2} \mathrm{O}_{3}$ spheres present below the smaller silica particles. This experiment's results are found in Figure B.9. It was extremely difficult to determine where the minimum fluidization point is on the figure due the consistent increase in the pressure drop with flow rate, but it most likely resides between $(1.0-1.75) \mathrm{cm} / \mathrm{s}$. It was suspected that the problem with the pressure drop increasing above the minimum fluidization point might involve the silica support getting trapped in the alumina packed bed. By increasing the flow rate, more and more, of the silica particles left the bed, causing the pressure drop to increase. Figure B.10 shows the result of a 
minimum fluidization experiment for the same particles at ambient temperature where no alumina buffer support was used. 


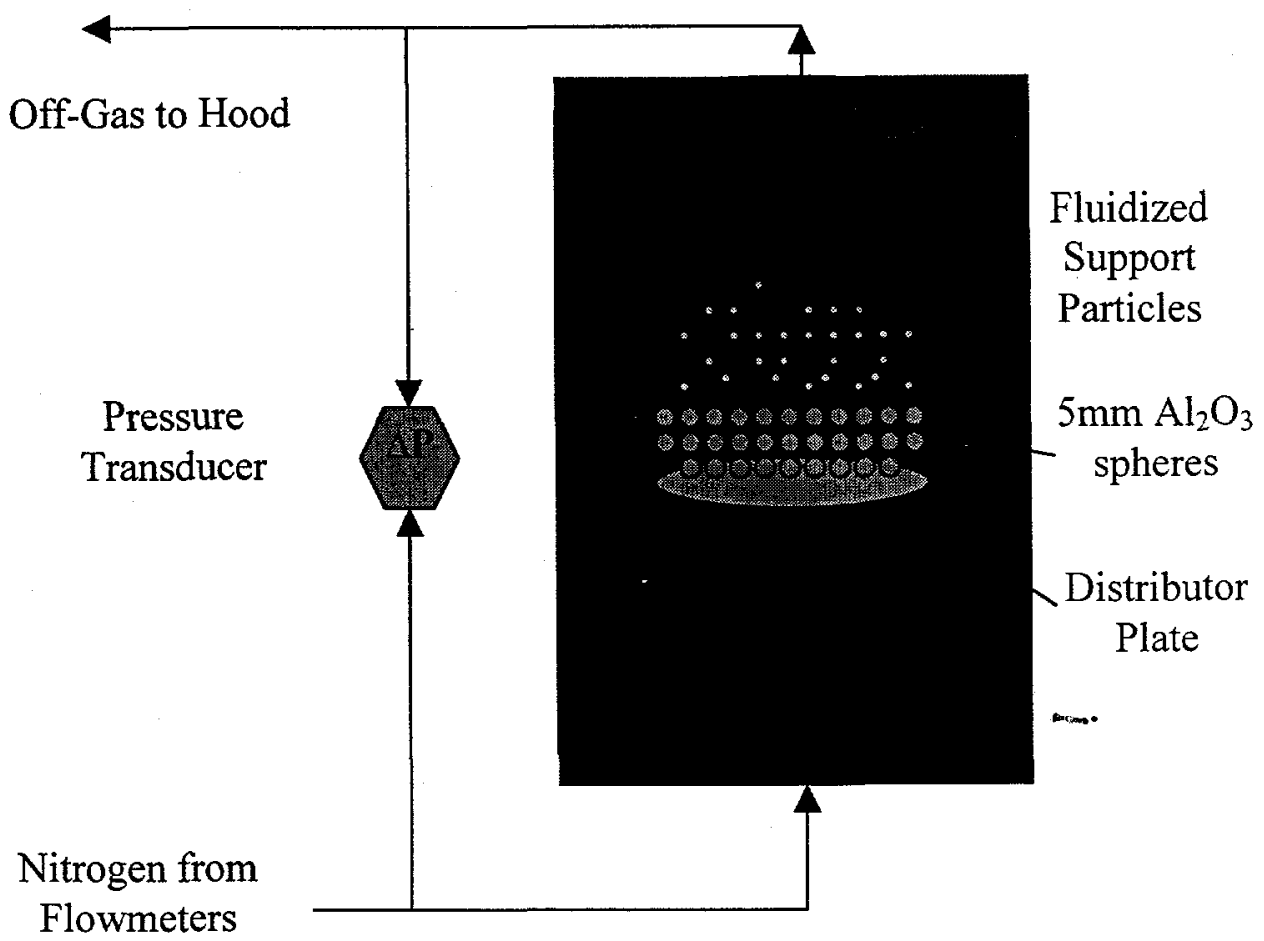

Figure B.8 Schematic for an Alternate Method for Calculating the Pressure Drop Across the Fluidized Bed. 
Minimum Fluidization Curve: Pressure Drop vs Superficial Velocity (Temp $25^{\circ} \mathrm{C}$, Support 350 gm of US Silica F-110, with $500 \mathrm{gm} \mathrm{Al}_{2} \mathrm{O}_{3}$ Buffer Support)

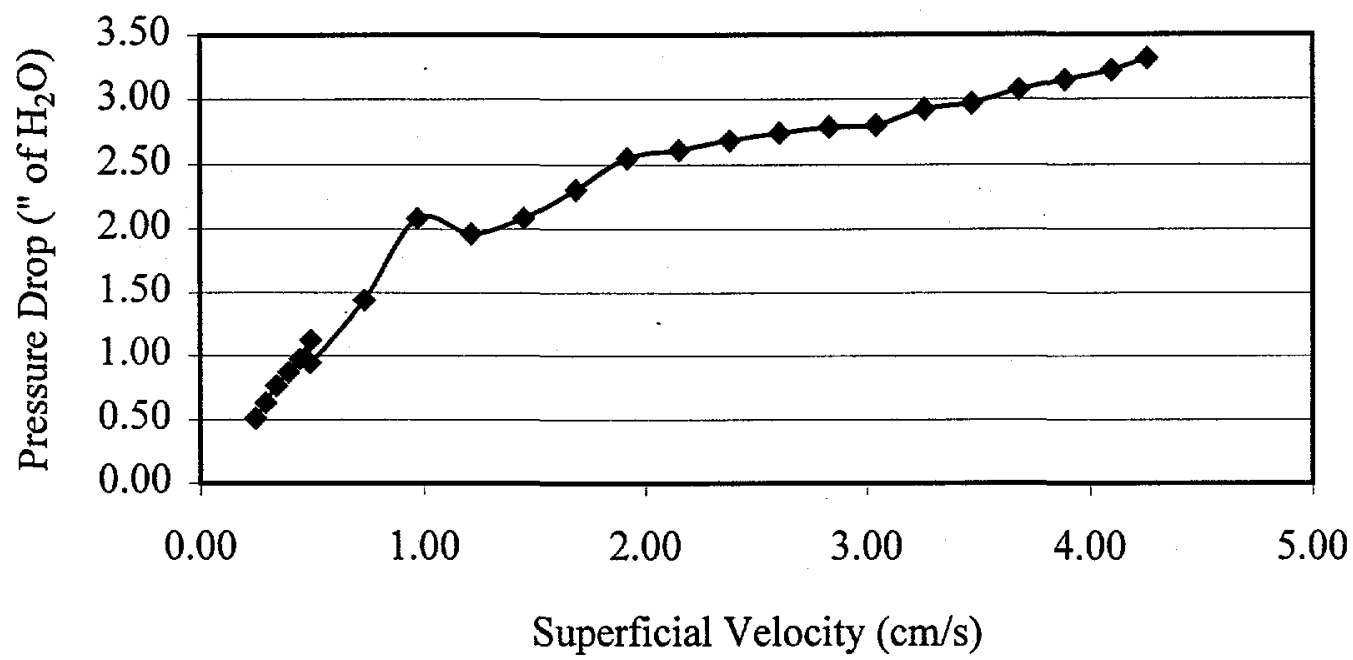

Figure B.9 Minimum Fluidization Curve for 350 grams of US Silica F-110 at $25^{\circ} \mathrm{C}$ with Buffer Support.

Minimum Fluidization Curve: Pressure Drop vs Superficial Velocity (Temp 25oC, Support 350 gm US Silica F-110, No Buffer Support)

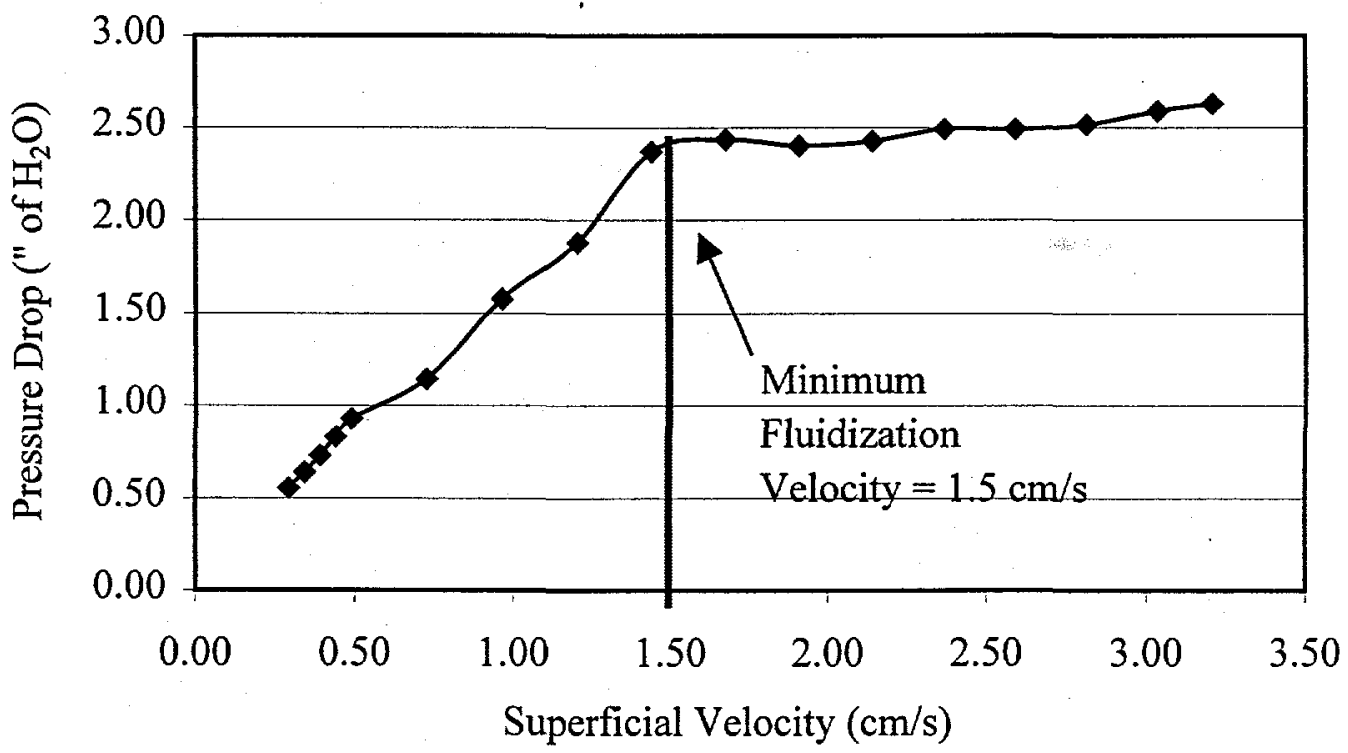

Figure B.10 Minimum Fluidization Curve for 350 grams of US Silica F-110 at $25^{\circ} \mathrm{C}$ with no Buffer Support. 
The minimum fluidization point is in the neighborhood of $1.5 \mathrm{~cm} / \mathrm{s}$ and the pressure drop beyond that point is fairly constant. The curve looks like a classical fluidization curve for this type of particles, except the pressure drop is much lower than the theoretical value of $897 \mathrm{~Pa}\left(3.6\right.$ " of $\left.\mathrm{H}_{2} \mathrm{O}\right)$. In order to check the accuracy of the two pressure measuring devices, a $U$-tube manometer was constructed and attached to the bleed valves seen in Figure B.3. The manometer pressure drop measurement typically fell between the other two experimental readings. After visually observing the fluidization characteristics of the bed at ambient temperature, it appeared that bubbling only occurred in one region of the bed.

The inability to completely fluidize the particles was a problem that could not be corrected without designing a new distributor plate. Unfortunately, due to the nature of alumina, in house changes to the fluidized bed reactor were impossible. As the Generation II reactor was designed and built, further experiments with the F-110 and L-60 were conducted. Prior to conducting the salt loading experiments, the minimum fluidization curves for F-110 and L-60 at elevated temperatures were obtained. The temperature region of interest was between $300-500^{\circ} \mathrm{C}$ because of the melting point and thermal stability of the salt used for salt loading experiments. The salt, $\mathrm{LiNO}_{3}$, melts at $251^{\circ} \mathrm{C}$ and dissociates at $600^{\circ} \mathrm{C}$. The fluidization curves for the F-110 support particles at $300^{\circ} \mathrm{C}$ and $400^{\circ} \mathrm{C}$ are shown in Figures B. 11 and B.12. Figure B.13 shows the minimum fluidization curve for the $\mathrm{L}-60$ support at $500^{\circ} \mathrm{C}$. The minimum fluidization velocities for each curve are $0.85 \mathrm{~cm} / \mathrm{s}, 0.8 \mathrm{~cm} / \mathrm{s}$, and 2.9 $\mathrm{cm} / \mathrm{s}$ respectively. 
Minimum Fluidization Curve: Pressure Drop vs Superficial Velocity (Temp - 300oC, Support 350 gm of US Silica F-110, No Buffer support)

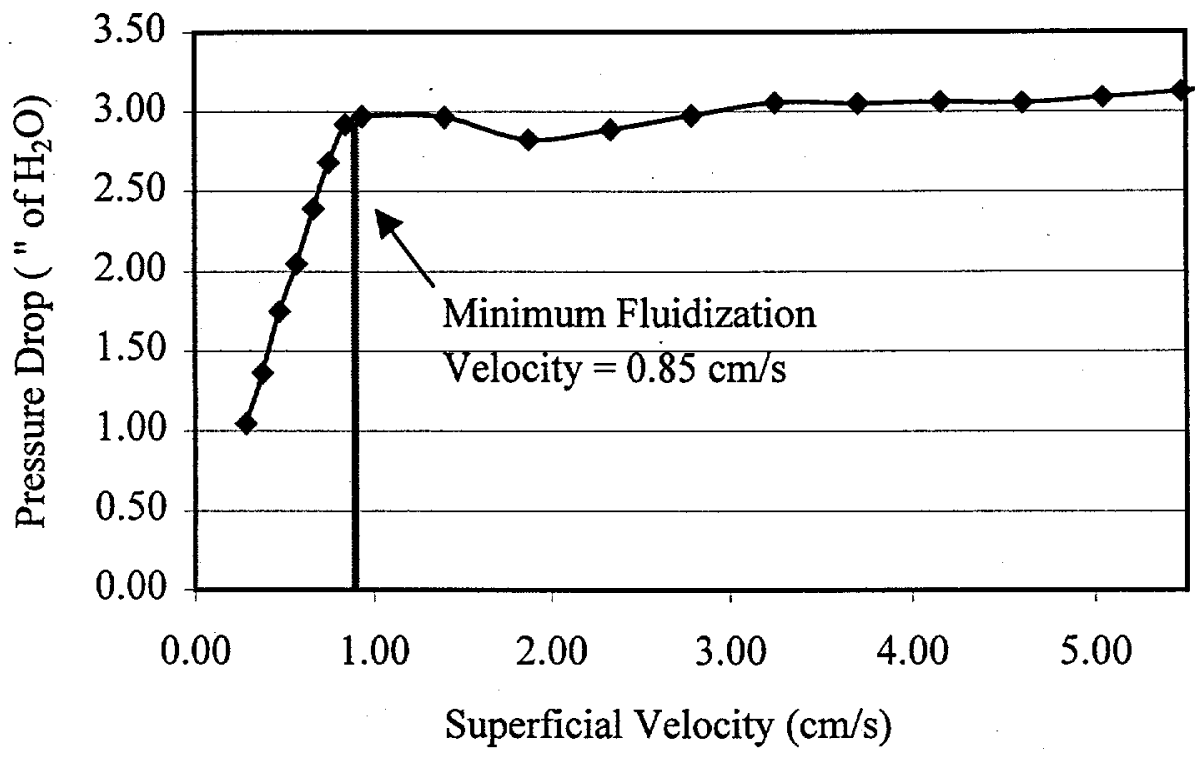

Figure B.11 Minimum Fluidization Curve for 350 grams of US Silica F-110 at $300^{\circ} \mathrm{C}$.

Minimum Fluidization Curve: Pressure Drop vs Superficial Velocity (Temp - 400oC, Support 350 gm of US Silica F-110, No Buffer support)

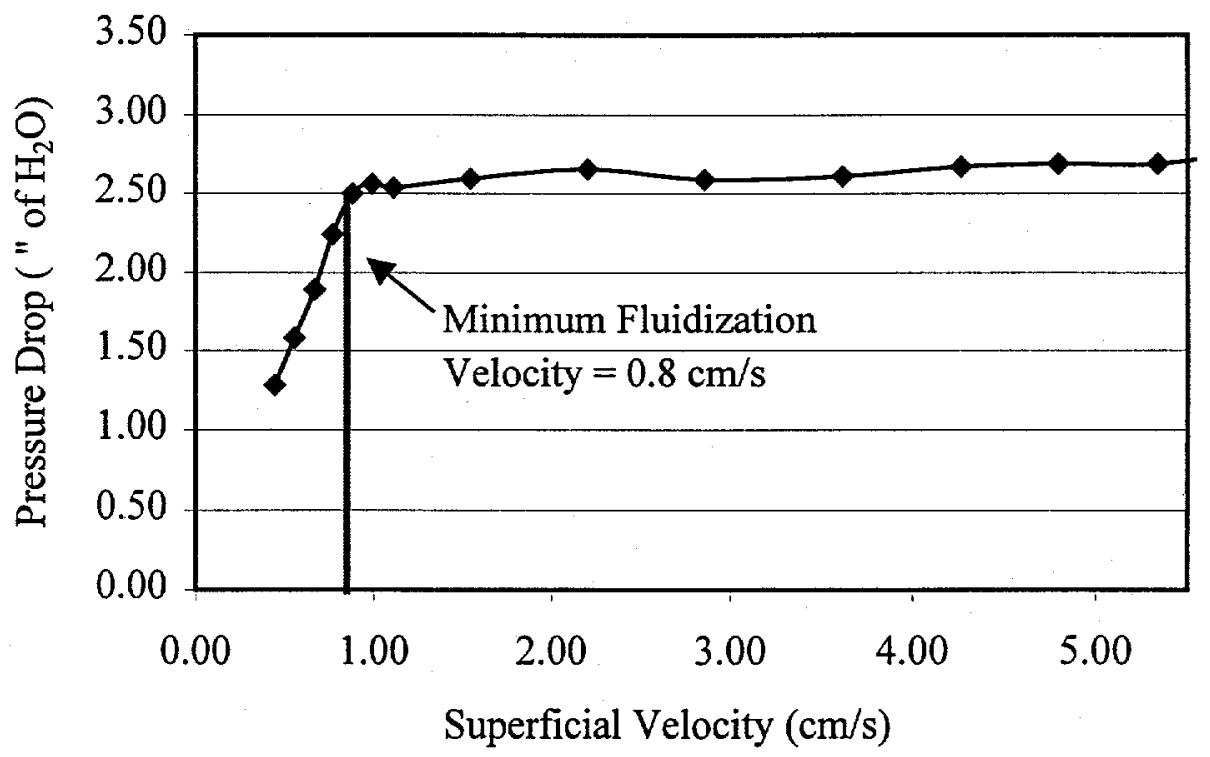

Figure B.12 Minimum Fluidization Curve for 350 grams of US Silica F-110 at $400^{\circ} \mathrm{C}$. 
Minimum Fluidization Curve: Pressure Drop vs Superficial Velocity (Temp - 500oC, Support 350 grams of US Silica L-60, No Buffer Support)

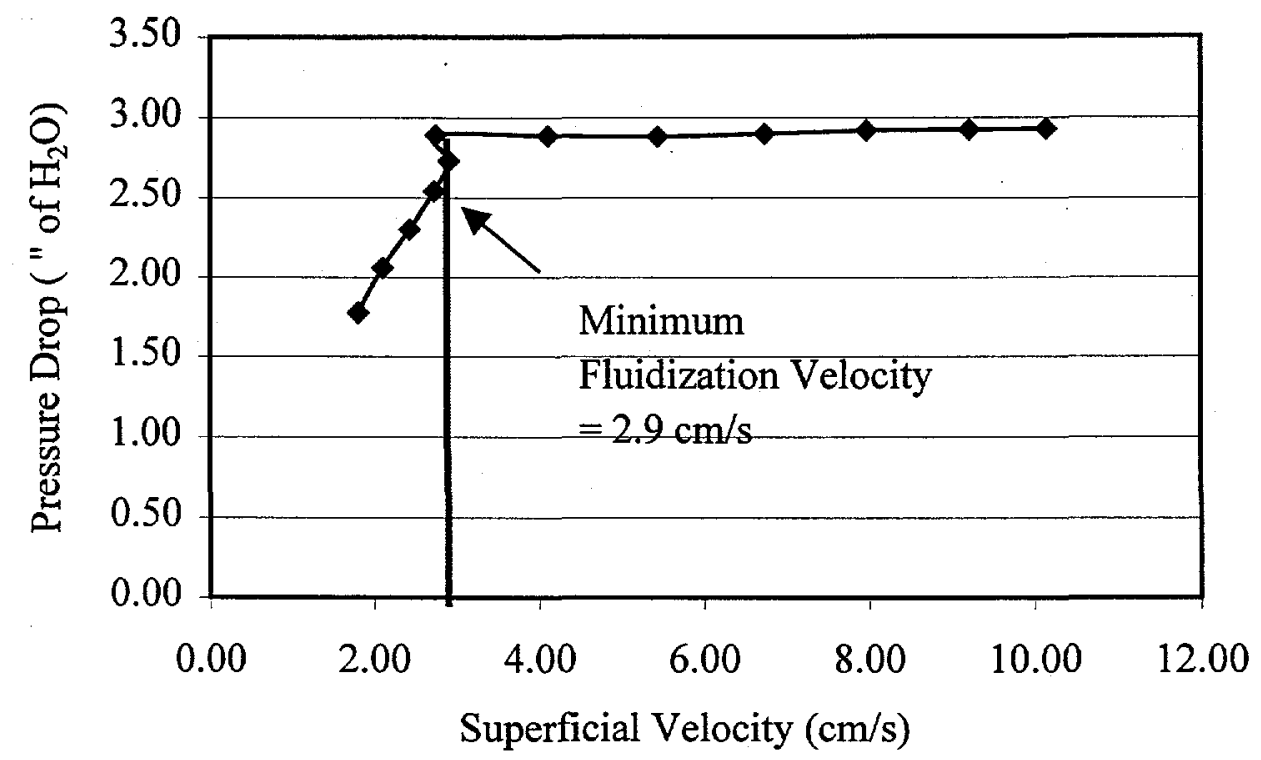

Figure B.13 Minimum Fluidization Curve for 350 grams of US Silica L-60 at $500^{\circ} \mathrm{C}$. 
For a sanity check, the L-60 minimum fluidization curve at ambient temperature was determined experimentally. The theoretical minimum fluidization velocity for silica particles with a sphericity of 0.9 and an average particle diameter of 250 microns was calculated. The $u_{\mathrm{mf}}$ theoretical was $4.97 \mathrm{~cm} / \mathrm{s}$ just slightly larger than the experimentally determined value for the smaller L-60 particles of $4.8 \mathrm{~cm} / \mathrm{s}$. The close proximity of the theoretical and experimental minimum fluidization values provided confidence that the flowmeters and the procedure used to calculate the superficial velocity were sound.

For an undetermined reason, the pressure drops measured above the minimum fluidization point were different for all three cases. During the process of running the experiments, the U-tube manometer readings were compared to the pressure drop values given by the pressure transducer and pressure gauge. Again, the manometer's readings closely matched those given by the pressure transducer and pressure gauge.

\section{B.3b) Salt Loading Experifinents.}

Figures B.14-B.16 contain the pressure drop across the bed of particles as a function of salt loading. The salt loading experiments were run at three different temperatures, different multiples of minimum fluidization velocity, and with two different size supports. By varying these parameters, one could begin to understand how the dimensionless groups important in the force balance between the particles affected the salt loading capability under different physical conditions.

The salt was added to the reactor using the pneumatic salt feeder in 1 gram increments. The pressure drop readings were recorded typically 20-30 minutes after the system had presumably reached a steady state. From Figures B.14-B.16, a clear trend does not exist between any of the cases. The data were also not consistent with the results obtained by Czerpak (Czerpak 1998). Figure B.14 shows the most promising results with a gradual pressure drop increase during the addition of the first seven grams of salt followed by an apparent collapse. Unfortunately, it was not made a practice to increase the flow rate through the bed to witness how that affected the pressure drop. Presumably, if the pressure drop remained constant even while increasing the flow rate, the bed was still in a fluidized state. This procedure was adopted for the Generation II experiments. The validity of the pressure drop readings were questionable due to the fact the pressure tube that measured the pressure directly above the distributor plate was typically clogged with particles and salt. Changes in the pressure drop measuring system were made to alleviate this problem for the Generation II experiments. 
Figure B.14 Salt Loading Experiment with $\mathrm{LiNO}_{3}$ for 350 grams of US Silica F-110 at $300^{\circ} \mathrm{C}$.

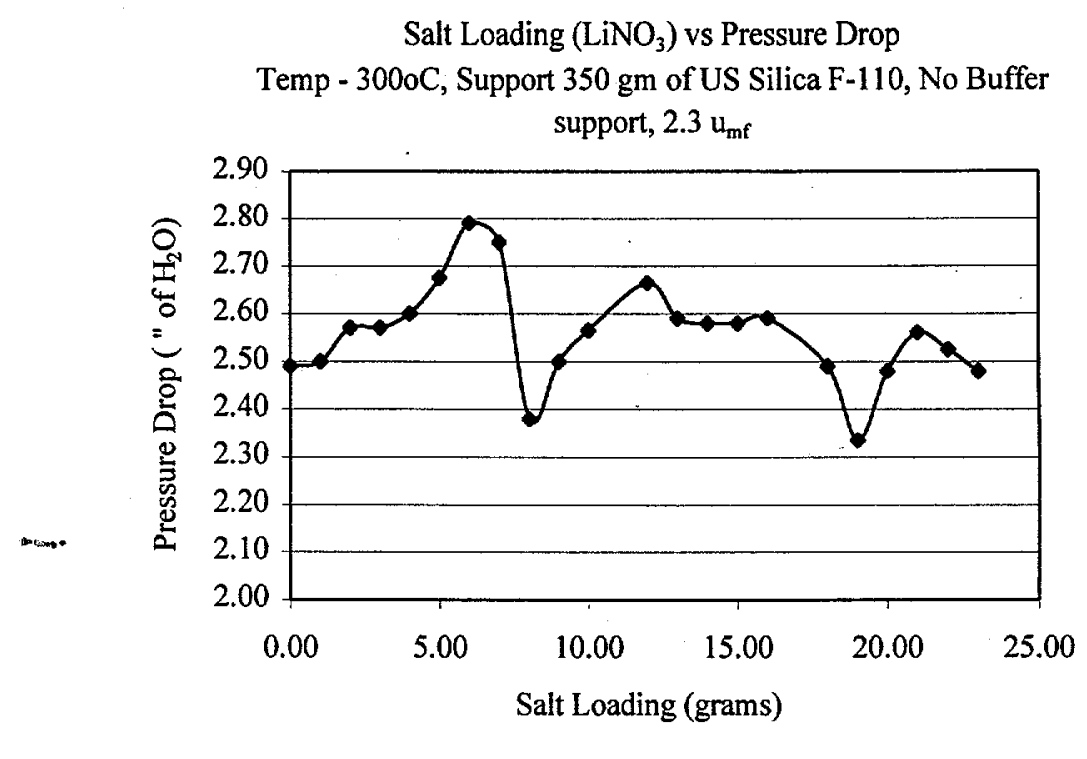

0

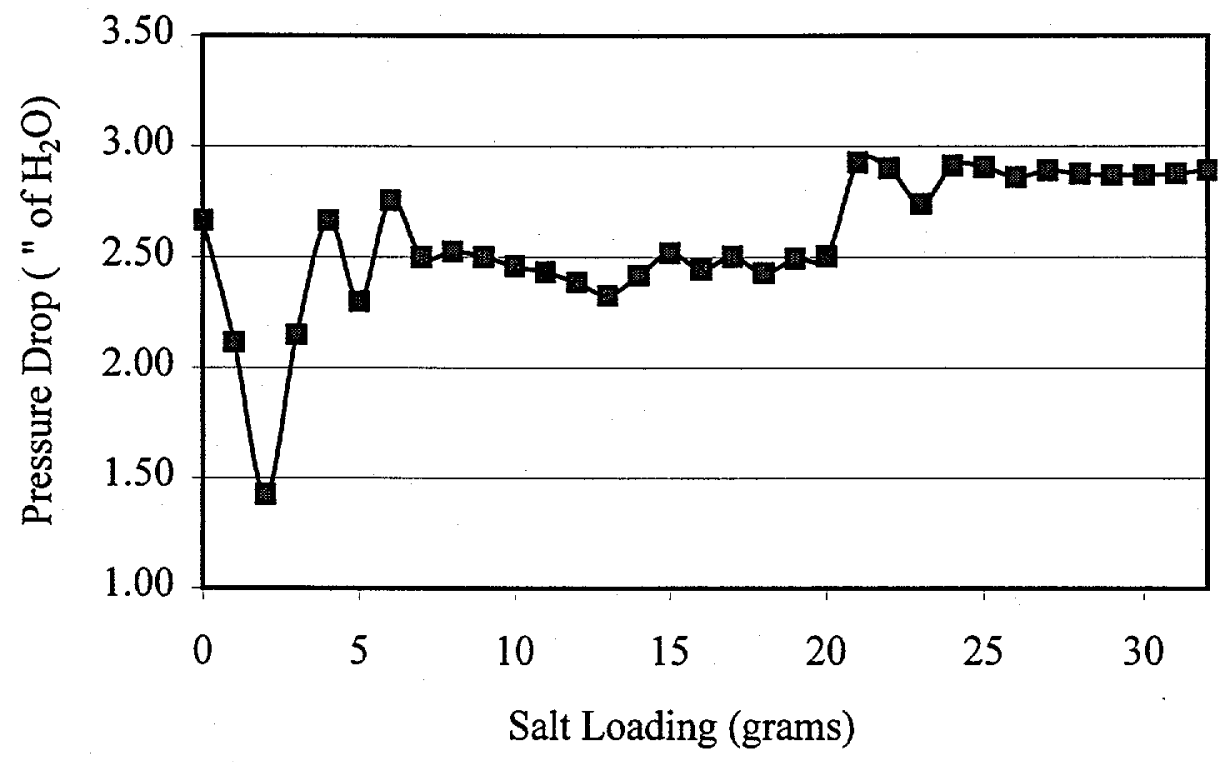

Figure B.15 Salt Loading Experiment with $\mathrm{LiNO}_{3}$ for 350 grams of US Silica $\mathrm{F}-110$ at $400^{\circ} \mathrm{C}$. 
Salt Loading $\left(\mathrm{LiNO}_{3}\right)$ vs Pressure Drop

(Temp-500oC, Support 350 gm of US Silica L-60, No Buffer

Support, $3 u_{m f}$ )

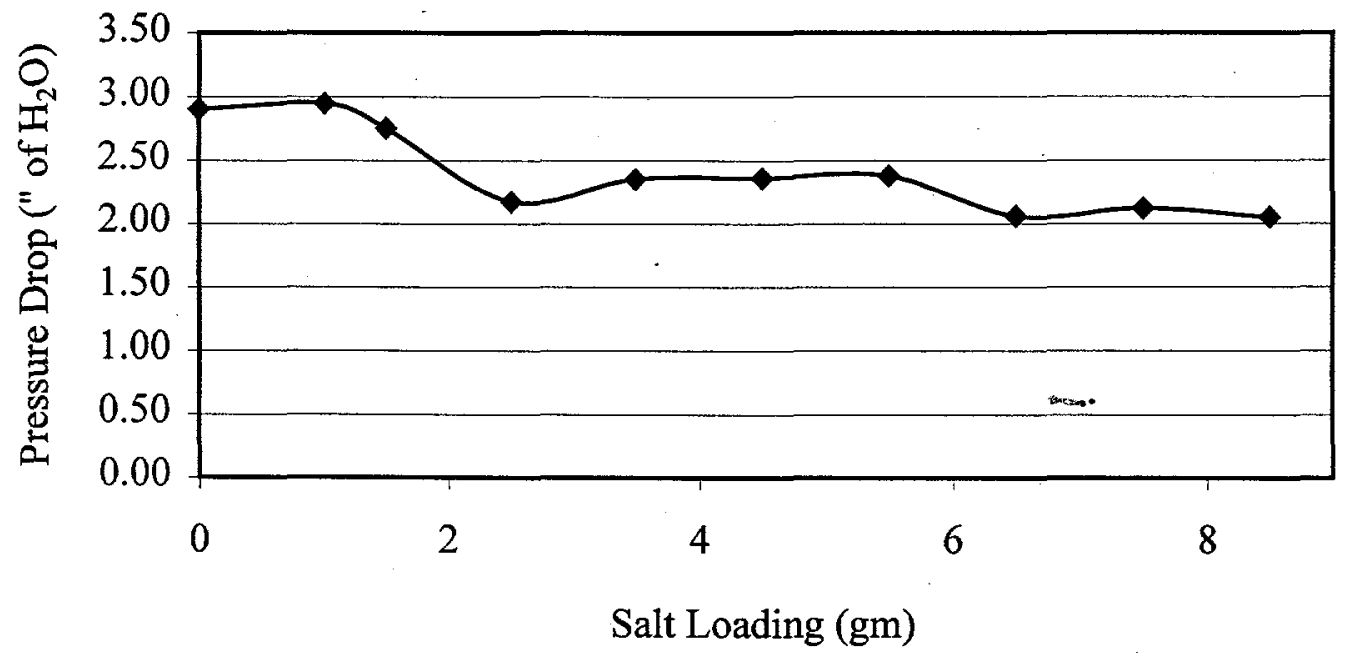

Figure B.16 Salt Loading Experiment with $\mathrm{LiNO}_{3}$ for 350 grams of US Silica L-60 at $500^{\circ} \mathrm{C}$. 


\section{B.4) Generation II - Data Collection Procedures/Results}

The second generation fluidized bed reactor was designed to fluidize larger diameter particles in order to take advantage of the greater inertial forces present in the bed of particles. The larger particle diameters and greater superficial velocity through the bed will increase the Reynolds number and hopefully overcome the molten salt's viscosity and high surface tension. Potter's Glass Ballotini, which are $>99 \%$ pure silica spheres, between 300-1100 microns were chosen for the initial experiments in the section. Table B.2 lists the potential samples of glass ballotini available for experimentation along with their advertised and experimentally determined average particle size range.

The particles were purchased from Potters Industries Inc. The experimentally determined particle size ranges were determined with Fisher Scientific USA Standard testing Sieves and a Cenco Sieve Shaker. A majority of the samples were well within the advertised size range. During the sieving process the fraction of the sample that did not reside on the main sieve tray was discarded. The remaining particles were discarded attempting to narrow the sample's particle size distribution and improve its fluidization characteristics.

The set up for the pressure drop measurement was altered for the generation II experiments to prevent clogging and give greater flexibility for measuring the pressure drop over different regions. A general schematic for the new pressure drop set up is shown in Figure B.6. The addition of the new tube into the bottom of the reactor made measuring the pressure drop over three different regions possible simply by manipulating the valves. Figure B.17 contains valve configurations for measuring the pressure drop across the bed of particles and the distributor plate (Configuration \#1), pressure drop across the bed of particles (Configuration \#2), and the pressure drop across the distributor plate (Configuration \#3). In order to accommodate the higher flow rates encountered in this section of experiments, the pressures gauges were replaced with a (0-3.74E4) $\mathrm{Pa}(0-150)$ " of $\mathrm{H}_{2} \mathrm{O}$ gauge for measuring the inlet reactor pressure and $(0-1.25 \mathrm{E} 4) \mathrm{Pa}(0-50)$ " of $\mathrm{H}_{2} \mathrm{O}$ gauge for measuring the pressure drop across the different regions of interest.

To minimize clogging in the pressure tube inserted into the bed of particles, configuration \#4 was used anytime the reactor was heating up or the flow rate through the reactor was increased. This kept the pressure inside the tube higher than the pressure of the gas above the distributor plate. This method proved very effective in keeping the particles from clogging the pressure tube. During data collection for minimum fluidization and salt loading experiments, the pressure drop measurements using configuration \#1 and \#2 were recorded and continually compared to each other to ensure that the changes in the corresponding pressure drop measurements were consistent. This method would detect when the pressure tube was clogged and the pressure drop measurement across the bed of particles was no longer accurate. 
Table B.2 Potters Glass Ballotini Particle Size Characteristics.

\begin{tabular}{|c|c|c|c|c|}
\hline $\begin{array}{c}\text { Sample } \\
\text { Identification }\end{array}$ & $\begin{array}{c}\text { Advertised } \\
\text { Size Range } \\
(\mu \mathbf{m})\end{array}$ & $\begin{array}{c}\text { Particle Size } \\
\text { Range } \\
(\mu \mathbf{m})\end{array}$ & $\begin{array}{c}\text { Sieve } \\
\text { Size }\end{array}$ & $\begin{array}{c}\text { Mass of } \\
\text { Sample } \\
(\text { grams })\end{array}$ \\
\hline $\begin{array}{c}\text { 1922 Lot 1117 } \\
(98)\end{array}$ & $\mathbf{1 5 0 - 2 5 0}$ & $212-300$ & $70-50$ & 758.81 \\
\cline { 3 - 5 } & & $150-212$ & $100-70$ & 141.45 \\
\hline P-0120 Lot 1119 & $\mathbf{2 1 0 - 3 0 0}$ & $212-300$ & $70-50$ & 806.34 \\
\hline P-170 Lot 14/93 & $\mathbf{3 0 0 - 4 3 0}$ & $300-425$ & $50-40$ & 844.4 \\
\hline $\begin{array}{c}\text { Mil \#5 Lot 119 } \\
\text { (98) }\end{array}$ & $\mathbf{3 0 0 - 4 2 5}$ & $300-425$ & $50-40$ & 750.24 \\
\hline B Lot 1119(98) & $\mathbf{4 2 5 - 6 0 0}$ & $425-600$ & $40-30$ & 106.1 \\
\hline A-055 Lot & $\mathbf{5 0 0 - 6 0 0}$ & $425-600$ & $40-30$ & 891.9 \\
\hline 073198 & & & $40-30$ & 904.16 \\
\hline $\begin{array}{c}\text { A-065 Lot 1 } \\
\text { 12/96 }\end{array}$ & $\mathbf{6 0 0 - 7 1 0}$ & $600-850$ & $30-20$ & 892.7 \\
\hline A Lot 1117 (98) & $\mathbf{6 0 0 - 8 5 0}$ & $600-850$ & $30-20$ & 832.29 \\
\hline A-085 Lot 2 1/97 & $\mathbf{7 1 0 - 8 5 0}$ & $850-1180$ & $20-16$ & 882.89 \\
\hline A-90 Lot 120897 & $\mathbf{8 0 0 - 1 1 0 0}$ & $850-1180$ & $20-16$ & 817.45 \\
\hline A-110 Lot & $\mathbf{1 0 0 0 - 1 2 0 0}$ & $850-1180$ & $20-16$ & 875.96 \\
070798 & & & & \\
\hline
\end{tabular}




\section{Configuration \#1}

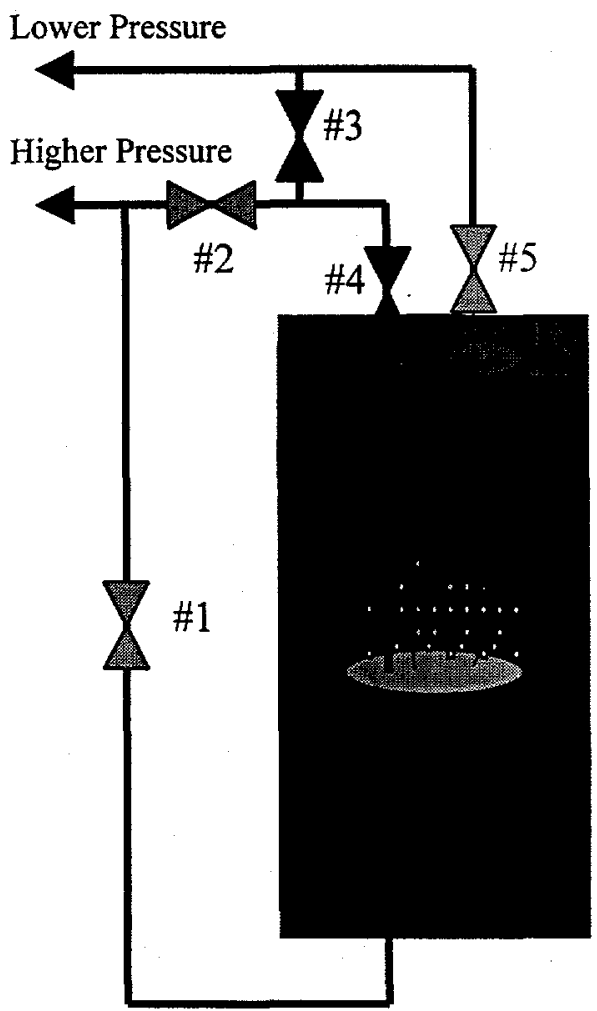

Configuration \#3

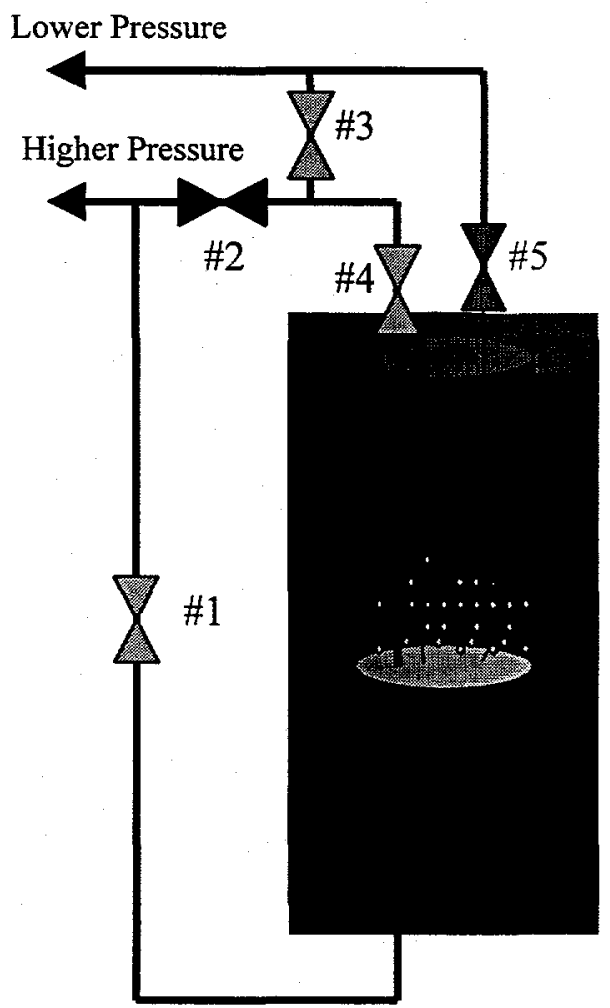

Configuration \#2

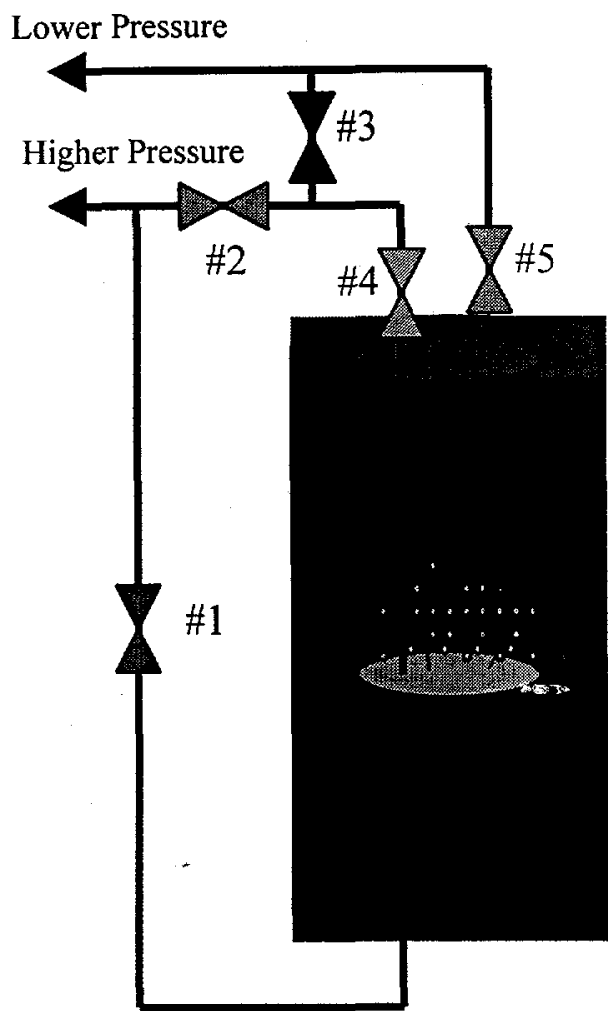

Configuration \#4

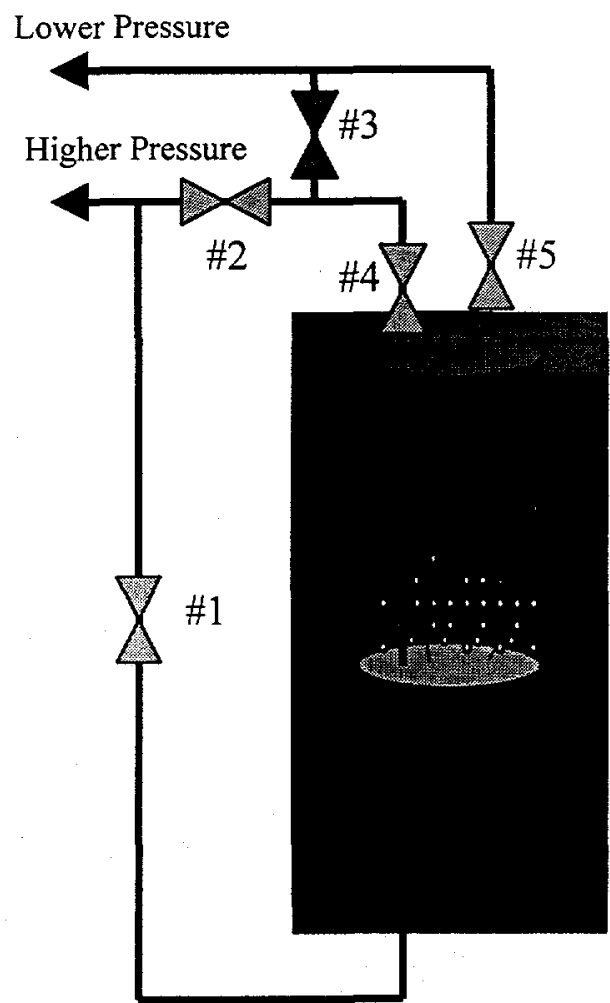

Figure B.17 Generation II Pressure Drop Measurement Configurations. 
An attempt was made to develop a curve fit equation for the pressure drop across the distributor plate as a function of the volumetric flow rate and temperature as a backup to the pressure drop measuring system just described. The pressure drop across the distributor plate and the volumetric flow rate data were taken and then plotted for various temperatures. The orifice equation has the pressure drop proportional to the square of the volumetric flow rate $\left(\Delta \mathrm{P} \propto \mathrm{Q}^{2}\right)$. Figure $\mathrm{B} .18$ shows a sample of the data collected for the distributor plate pressure drop versus volumetric flow rate at $400^{\circ} \mathrm{C}$. The expectation is for a straight line to form by plotting the square root of the pressure drop against the flow rate. Figure B.18 does give a plot very close to a straight line, but there is a sudden change in the line around 60 $(\mathrm{L} / \mathrm{min})$. This discontinuity occurs when switching from the $\mathrm{B}$ to $\mathrm{H}$ flowmeter. There is a slight difference between the distributor plate pressure drop for the same "measured" flow rate between the two flowmeters. After extensive discussions with the support staff at Brooks Instruments, the validity of the temperature and pressure corrections made to calculate the actual flow rates were verified. It was concluded that the B flowmeter is not as accurate at the lower region of its scale and at pressures significantly lower than its calibrated pressure $3.4 \mathrm{E} 4 \mathrm{~Pa}$ (5 psig). Even small differences between the two flowmeters can make a big difference at elevated temperatures. The reactor temperature correction exacerbates the error and makes developing one equation for the distributor plate pressure drop as a function of volumetric flow rate impractical. 
Figure B.18 Generation II Distributor Plate Pressure Drop versus Volumetric Flow Rate at $400^{\circ} \mathrm{C}$.

Distributor Plate Pressure Drop vs Volumetric Flow Rate at $400 \mathrm{oC}$

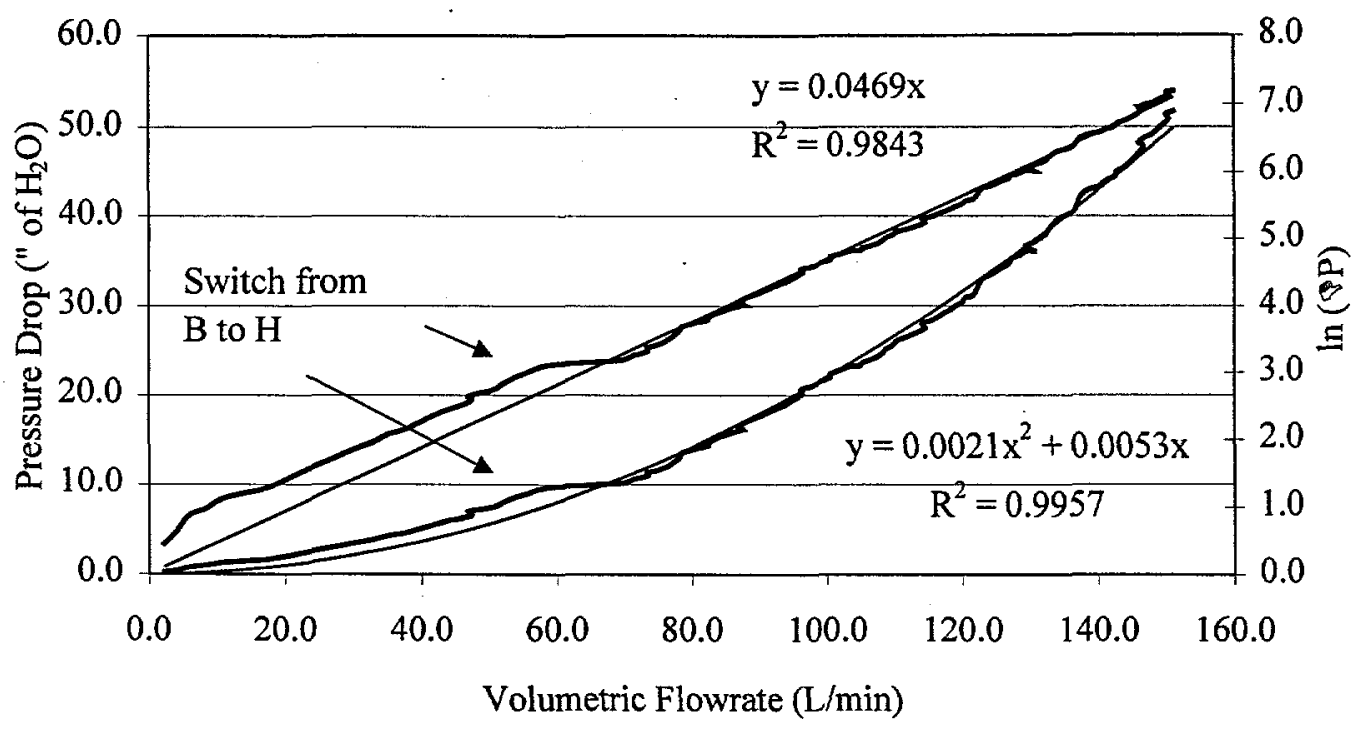




\section{B.4a) Minimum Fluidization Calculations for "P-170"}

The glass ballotini support "P-170" was chosen to test out the new fluidized bed reactor and pressure drop measuring system. The first experiments compared the experimental pressure drop above minimum fluidization to the theoretical value to test the new reactor. For a particle loading of 350 grams and bed diameter of $7.49 \mathrm{~cm}$ $\left(2.95^{\prime \prime}\right)$, the pressure drop across the bed of particles bed loading should be just over $7.47 \mathrm{~Pa}\left(3\right.$ " of $\mathrm{H}_{2} \mathrm{O}$ ). Figures B.19-B.22 are all minimum fluidization curves for "P170 " at four different temperatures. The experiments began by loading the particles into the reactor with sufficient flow through the bed to keep the particles from falling through the distributor plate. The reactor was then brought up to temperature with the pressure drop measuring system in configuration \#4. Once the desired temperature was reached, the pressure drop readings were taken for both configurations \#1 and \#2 along with the inlet pressure from Validyne PTDR \#.2 The graphite element temperature was also lowered as the flow rate was decreased through the bed to maintain the reactor temperature to with $+1-5^{\circ} \mathrm{C}$ of the desired reactor temperature. The minimum fluidization figures show that an average measured pressure drop above the minimum fluidization point is typically around $747 \mathrm{~Pa}\left(3.0\right.$ " of $\left.\mathrm{H}_{2} \mathrm{O}\right)$, which matches extremely well with the theoretical value. There was excellent dynamic response in the pressure drop measurements along with a clear pressure tube upon cleaning the reactor. These facts point toward the improved accuracy and effectiveness of the new pressure drop measuring system.

The minimum fluidization velocities at elevated temperature were significantly lower than at ambient temperature, which concurs with theory. The minimum fluidization velocity at ambient temperature is around $8.0 \mathrm{~cm} / \mathrm{s}$.

\section{B.4b) Trial Salt Loading Experiments}

Three salt loading experiments were completed to test out the salt feeder at higher gas velocities through the reactor and to see how the pressure tube responded to the presence of molten salt. The salt loading experiments were run at $300^{\circ} \mathrm{C}$ at $4 \mathrm{u}_{\mathrm{mf}}$, then $500^{\circ} \mathrm{C}$ at $5 \mathrm{u}_{\mathrm{mf}}$ and finally at $500^{\circ} \mathrm{C}$ at $7.5 \mathrm{u}_{\mathrm{mf}}$ to examine the pressure drop behavior. For the first trial, $\mathrm{LiNO}_{3}$ was injected using the pneumatic salt feeder at one-gram increments. Prior to using the salt feeder to inject salt into the reactor, two "dry" injections were performed to examine the bed's response to a blast of highpressure nitrogen. The nitrogen without the salt had no sustained effect on the pressure drop across the bed. 
Minimum Fluidization Curve: Pressure Drop vs Superficial Velocity (Temp $25^{\circ} \mathrm{C}$, Support 350 gm of Glass Ballotini "P$\left.170^{\prime \prime}\right)$

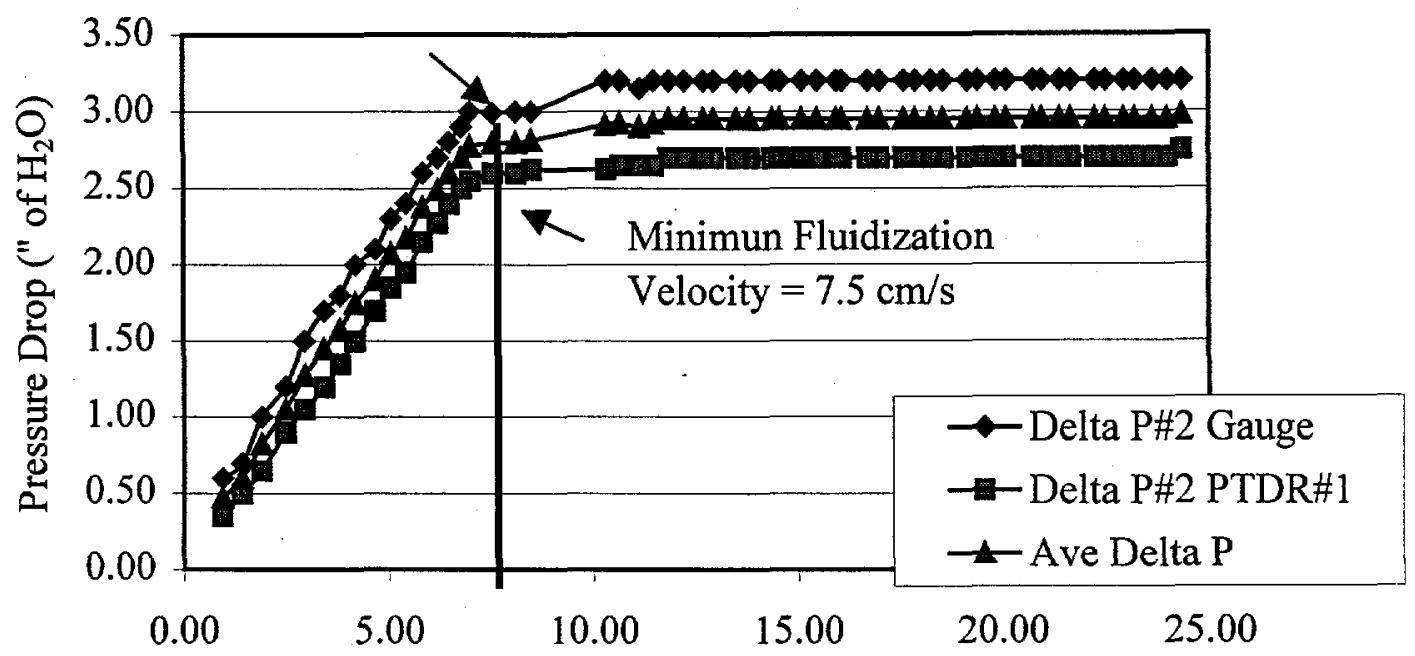

Superficial Velocity $(\mathrm{cm} / \mathrm{s})$

Figure B.19 Minimum Fluidization Curve for 350 grams of Glass Ballotini "P-170" at $25^{\circ} \mathrm{C}$.

Minimum Fluidization Curve: Pressure Drop vs Superficial Velocity (Temp 300oC Support 350 gm of Glass Ballotini "P-

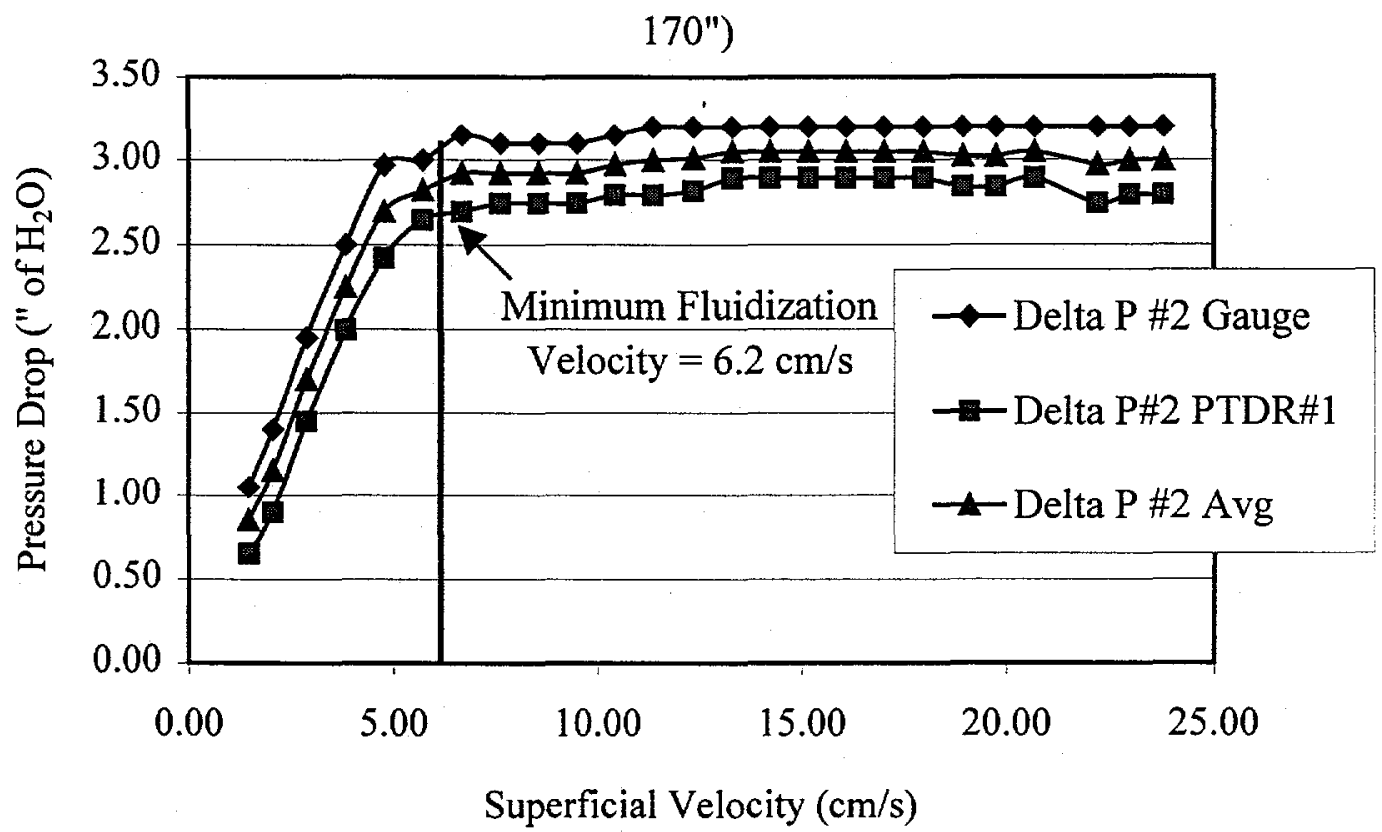

Figure B.20 Minimum Fluidization Curve for 350 grams of Glass Ballotini "P-170" at $300^{\circ} \mathrm{C}$. 
Minimum Fluidization Curve: Pressure Drop vs Superficial Velocity (Temp 400oC Support 350 gm of Glass Ballotini "P-

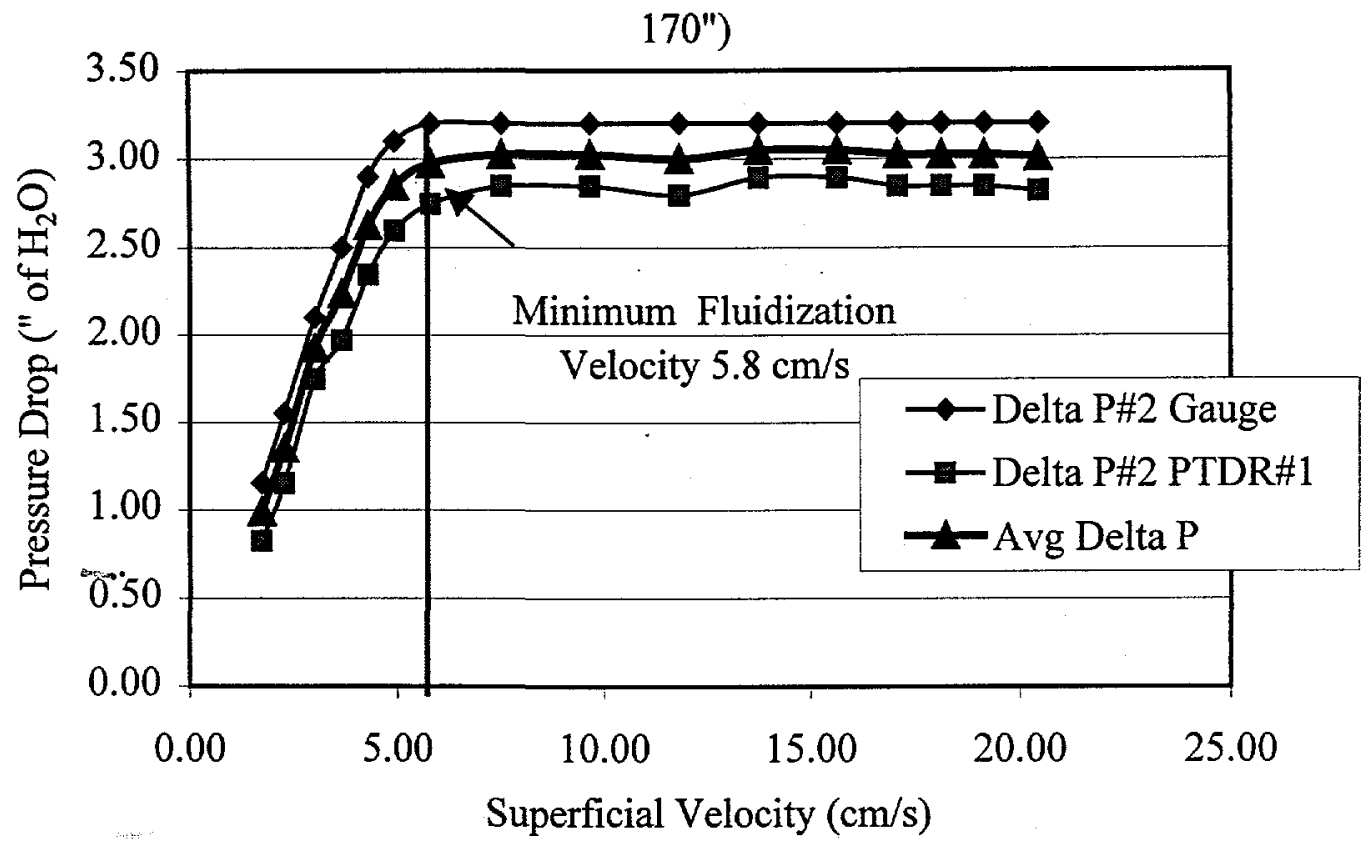

Figure B.21 Minimum Fluidization Curve for 350 grams of Glass Ballotini "P-170" at $400^{\circ} \mathrm{C}$.

Minimum Fluidization Curve: Pressure Drop vs Superficial Velocity (Temp 500oC Support 350 gm of Glass Ballotini

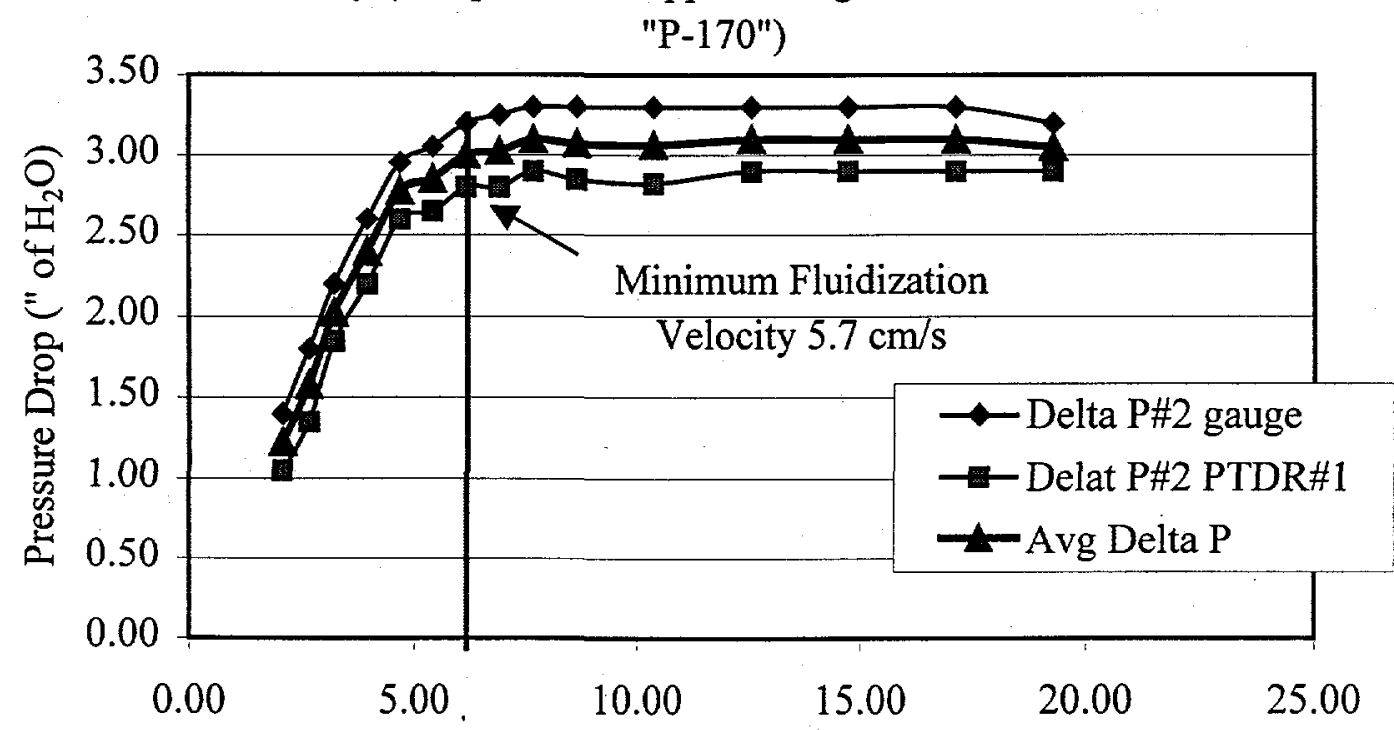

Superficial Velocity $(\mathrm{cm} / \mathrm{s})$

Figure B.22 Minimum Fluidization Curve for 350 grams of Glass Ballotini "P-170" at $500^{\circ} \mathrm{C}$. 
While fluidized at $300^{\circ} \mathrm{C}$ and $4 \mathrm{u}_{\mathrm{mf}}$, salt was added to the reactor. The first gram of salt caused the bed to collapse, which was signified by a dramatic decrease in the pressure drop across the bed and a slight temperature drop in this case. Five more grams of salt were injected over a period of 12 hours, but the pressure drop never recovered. The final pressure drop across the bed was $224 \mathrm{~Pa}\left(0.9\right.$ " of $\left.\mathrm{H}_{2} \mathrm{O}\right)$. Prior to cooling the reactor, the volumetric flow rate through the bed was increased to determine its effect on the pressure drop. If the bed was still in a fluidized state, the pressure drop should stay approximately constant while increasing flow rate. Figure B.23 shows that a linear relationship between the pressure drop and the superficial velocity exists, which indicates a collapsed bed. A solid matrix of particles and salt that had formed on top of the collapsed bed was visible upon taking the reactor apart. The matrix was easily broken up with a metal rod and the bed refluidized at ambient temperature. The particles were removed using a vacuum and then ground with a mortar and pestle to break up the remaining agglomerates. 
Figure B.23 Linear Relationship between $\Delta \mathrm{P}$ and Volumetric Flow Rate across a Collapsed Bed.

Pressure Drop vs Superficial Velocity for 350 gm of Glass Ballotini "P$170^{\prime \prime}$ at $300 \mathrm{oC}$ after Salt Loading

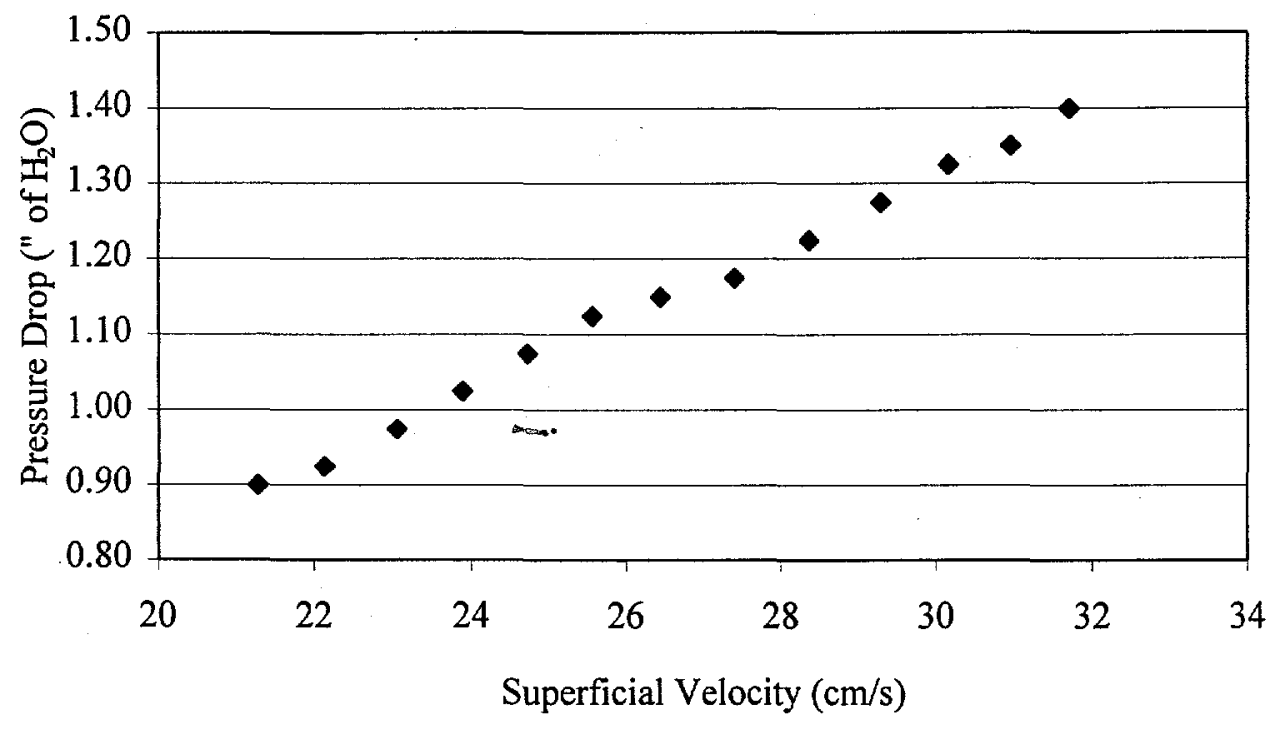


An additional five grams of $\mathrm{LiNO}_{3}$ were added to the particles before putting them back into the reactor. The particles were easily fluidized at ambient temperature. This experiment looked to see if there was any difference in the bed behavior when the salt is already present in the fluidized bed as the salt melts. The pressure drop was recorded every $20^{\circ} \mathrm{C}$ as the reactor temperature increased. The pressure drop remained constant up to $250^{\circ} \mathrm{C}$, which happens to be the melting point of $\mathrm{LiNO}_{3}$. The pressure drop decreased only slightly as the temperature continued to go up until reaching $270^{\circ} \mathrm{C}$. The temperature paused for almost five minutes during which the pressure drop went down significantly. The pressure drop continued to decrease as the temperature went up, presumably due to the bed of particles collapsing.

The next experiment, at $500^{\circ} \mathrm{C}$ at $5 \mathrm{u}_{\mathrm{mf}}$, exhibited some very bizarre behavior. The first attempt at this experiment saw the bed collapse as the reactor heated up. Again, the bed collapse occurred at a temperature slightly higher than $\mathrm{LiNO}_{3}$ 's mellt?ing point. The Inconel ${ }^{\mathrm{TM}}$ reactor at the end of the previous experiment was only cleaned with a vacuum to remove the clumps of particles and salt and the a wire brush and damp sponge to remove the remaining salt on the reactor walls. Apparently, the small amount of salt that was still on the walls of the reactor was enough to initiate bed collapse. This meant that after each experiment the entire fluidized bed had to be removed and water washed before the addition of new, clean particles.

The reactor was removed and new particles were added. The water washing worked as the pressure drop remained constant while passing through the salt's melting point. With a reactor temperature of $500^{\circ} \mathrm{C}$ at $5 \mathrm{u}_{\mathrm{mf}}$ there was an average pressure drop of $747 \mathrm{~Pa}\left(3.0\right.$ " of $\left.\mathrm{H}_{2} \mathrm{O}\right)$ across the fluidized bed. The salt feeder was "dry" injected twice with no effect. Initially, 0.25 grams of salt were injected into the bed with no effect on the pressure drop. Then another 0.25 grams was injected and the bed collapsed as indicated by a sharp decrease in the bed temperature and pressure drop. Over a period of two hours the temperature climbed up to just below the original value, as did the pressure drop. This same phenomenon was observed after each successive addition of 0.25 grams of salt, with the exception that the temperature did not return to $500^{\circ} \mathrm{C}$ unless the graphite element temperature was increased. On the first two occasions, as the bed refluidized the temperature in the reactor jumped all the way up to $550^{\circ} \mathrm{C}$. This occurred because the graphite element temperature was increased to warm the bed back to the original temperature of $500^{\circ} \mathrm{C}$, not expecting the bed to refluidize. The temperature jumped quickly when the bed refluidized. The bed appeared to refluidize with each successive addition of salt, up to 6.25 grams.

The collapsed bed at ambient temperature looked similar to the previous experiment, but it had a distinct green color to it. It was also very difficult to break up, and the agglomerates no longer dissolved during water washing. Considering all of these factors it appears that a chemical reaction occurred, which might somehow attribute to this bizarre refluidization phenomenon. Not once in the remaining salt loading experiments performed did the bed refluidize once it had collapsed.

This experiment was repeated to see if the results could be duplicated. In this case, after salt addition, the bed collapsed and never refluidized even after waiting for 
over 24 hours. The apparent chemical reaction occurred again indicating that once should avoid this temperature in the future.

\section{B.4c) Glass Ballotini Experimental Design}

To efficiently investigate the various glass ballotini supports, an experimental design matrix was created as seen in Figure B.24. The variables of interest are temperature, velocity above minimum fluidization, and particle size. The experiments were all run at $400^{\circ} \mathrm{C}$. The temperature was fixed at $400^{\circ} \mathrm{C}$ in order to avoid the apparent chemical reaction around $500^{\circ} \mathrm{C}$ and temperatures in the bed below the melting point if operated around $300^{\circ} \mathrm{C}$ due to large radial temperature developing gradients upon bed collapse.

Four different average diameter supports covering the 300-1100 micron size range were selected for the experimental design matrix in Figure B.24. The four supports chosen are listed in Table B.3. 
Table B.3 Glass Ballotini Specs for Experimental Design Matrix.

\begin{tabular}{|c|c|}
\hline Designator & $\begin{array}{c}\text { Avg dp } \\
\text { (Microns) }\end{array}$ \\
\hline MIL \#5 Lot 1119 & 350 \\
\hline A-055 & 550 \\
\hline A-085 & 850 \\
\hline A-110 & 1100 \\
\hline
\end{tabular}

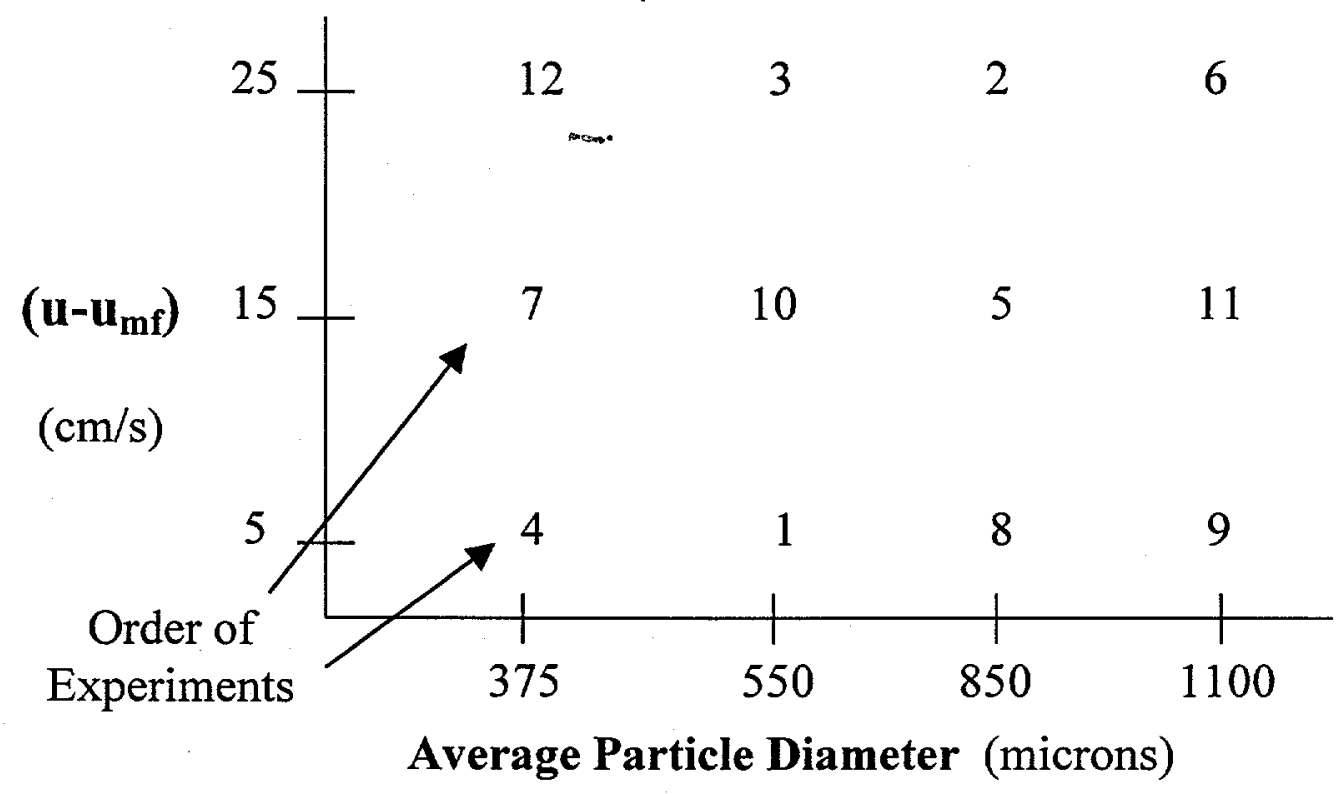

Figure B.24 Glass Ballotini (375-1100 $\mu \mathrm{m})$ with the Pneumatic Salt Injector Experimental Design Matrix. 
Drawing numbers out of a hat randomized the order of experiments. Prior to running the salt experiments, the minimum fluidization curves for each support were generated. Figures B.25-B.28 contain the minimum fluidization curves for the supports tested in this section. The fluidization curves' pressure drops above the minimum fluidization velocity are consistent from support to support and match well with the theoretical values. The minimum fluidization velocities are also consistent with theoretical predictions: The individual support's minimum fluidization velocities at $400^{\circ} \mathrm{C}$ are all lower than those predicted by theory at ambient temperature. 
Minimum Fluidization Curve: Pressure Drop vs. Superficial Velocity (Temp 400oC Support 350 gm of Glass Ballotini "MIL \#5 Lot 1119")

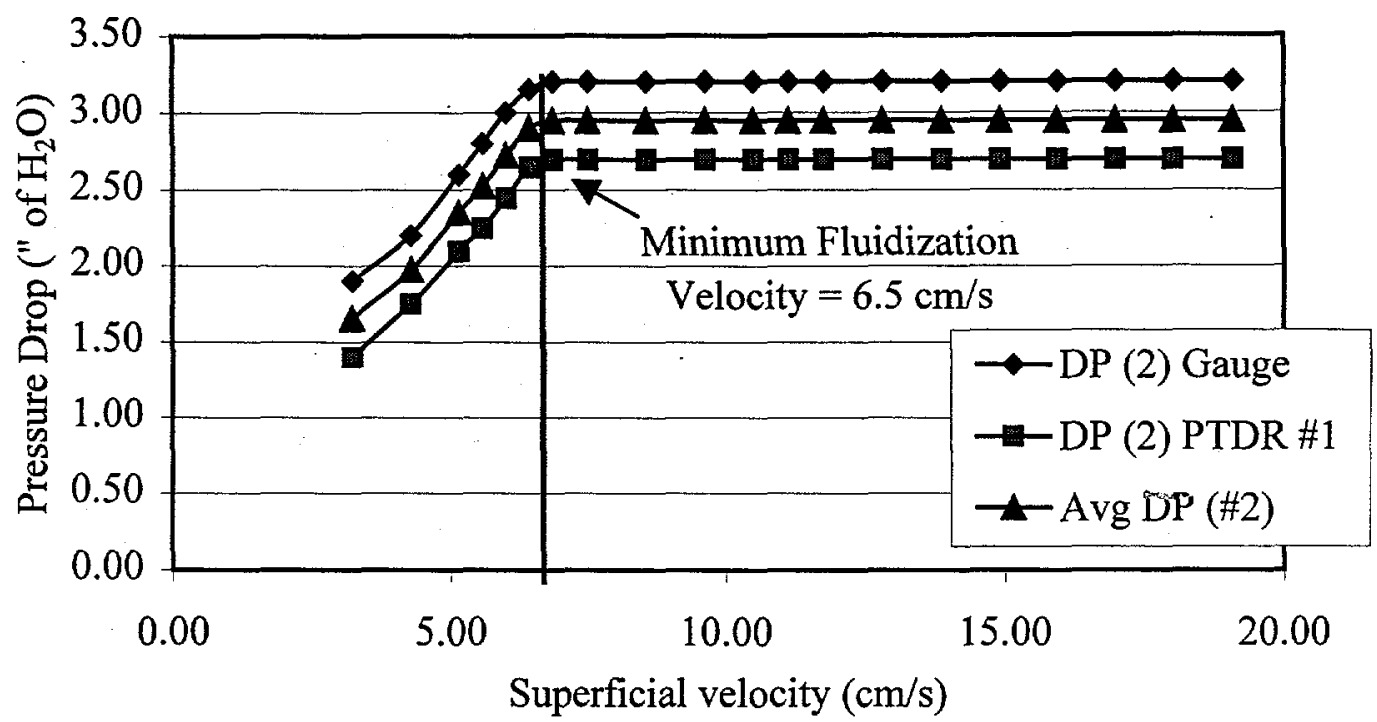

Figure B.25 Minimum Fluidization Curve for 350 grams of Glass Ballotini MIL \#5 Lot 1119 at $400^{\circ} \mathrm{C}$.

Minimum Fluidization Curve: Pressure Drop vs Superficial Velocity (Temp 400oC Support $350 \mathrm{gm}$ of Glass Ballotini

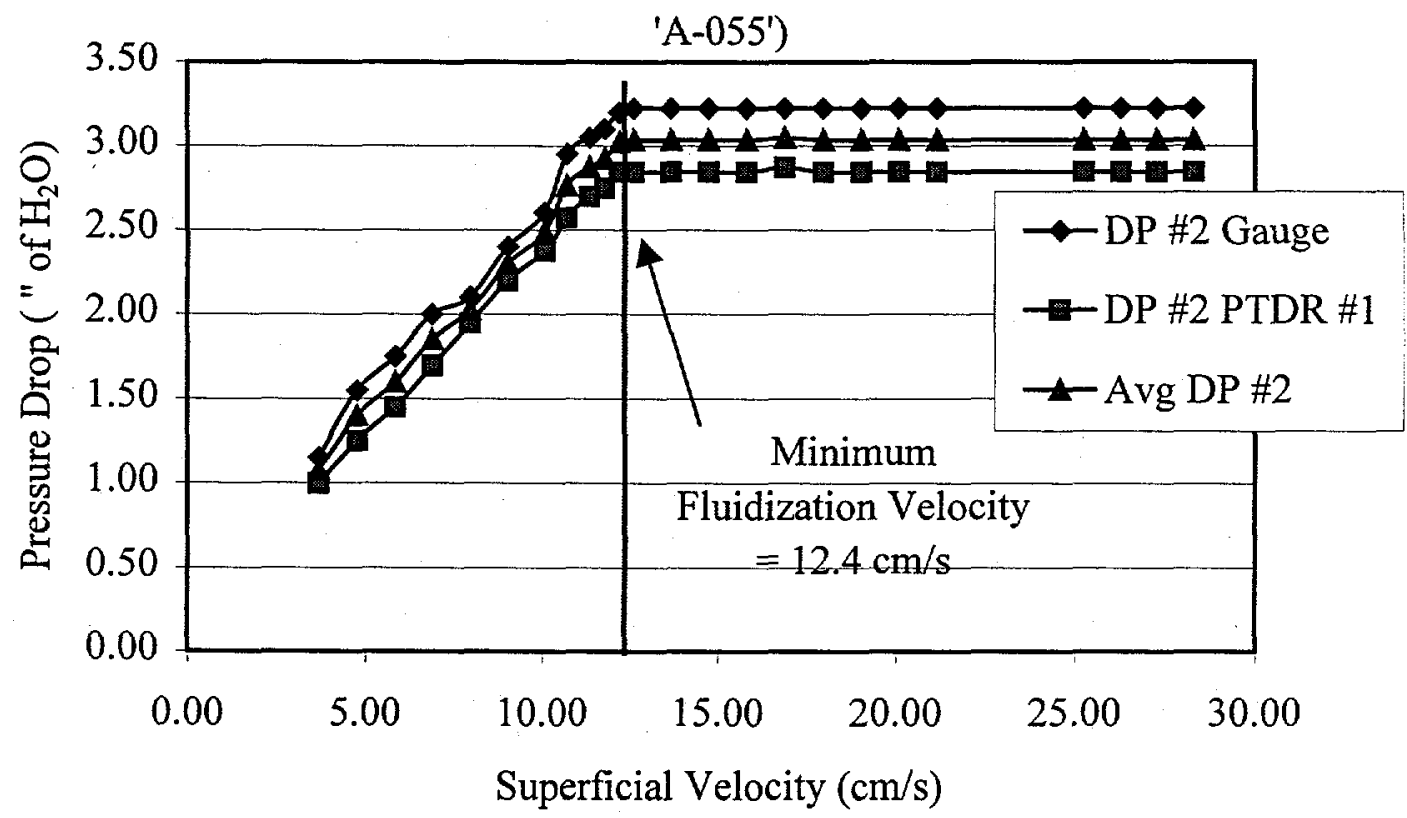

Figure B.26 Minimum Fluidization Curve for 350 grams of Glass Ballotini "A-055" at $400^{\circ} \mathrm{C}$. 
Minimum Fluidization Curve: Pressure Drop vs. Superficial

Velocity (Temp 400oC Support 350 gm of Glass Ballotini "A$085^{\prime \prime}$

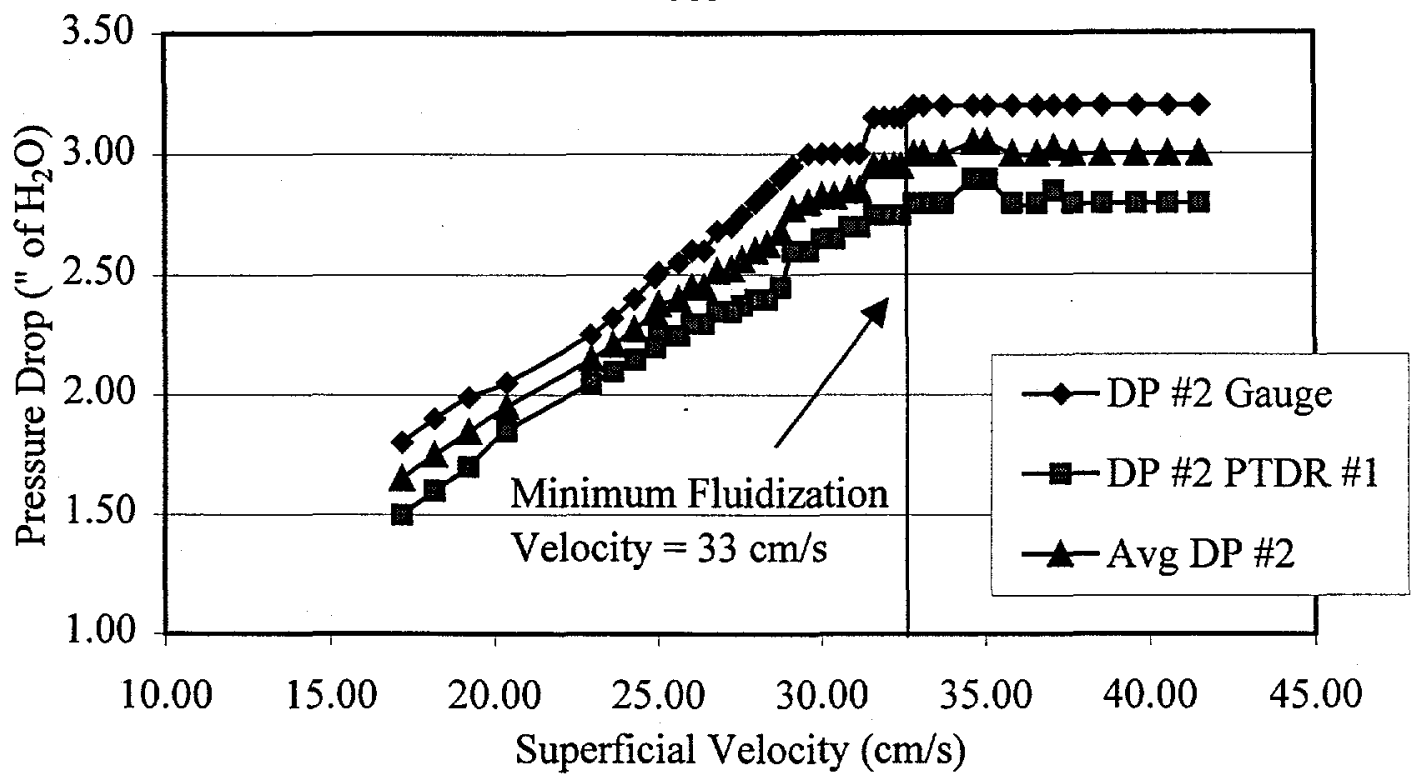

Figure B.27 Minimum Fluidization Curve for 350 grams of Glass Ballotini "A-085" at $400^{\circ} \mathrm{C}$.

Figure B.28 Minimum Fluidization Curve for 350 grams of Glass Ballotini "A-110" at $400^{\circ} \mathrm{C}$.

Minimum Fluidization Curve: Pressure Drop vs. Superficial Velocity (Temp $400 \mathrm{oC}$ Support 350 gm of Glass Ballotini, "A-110")

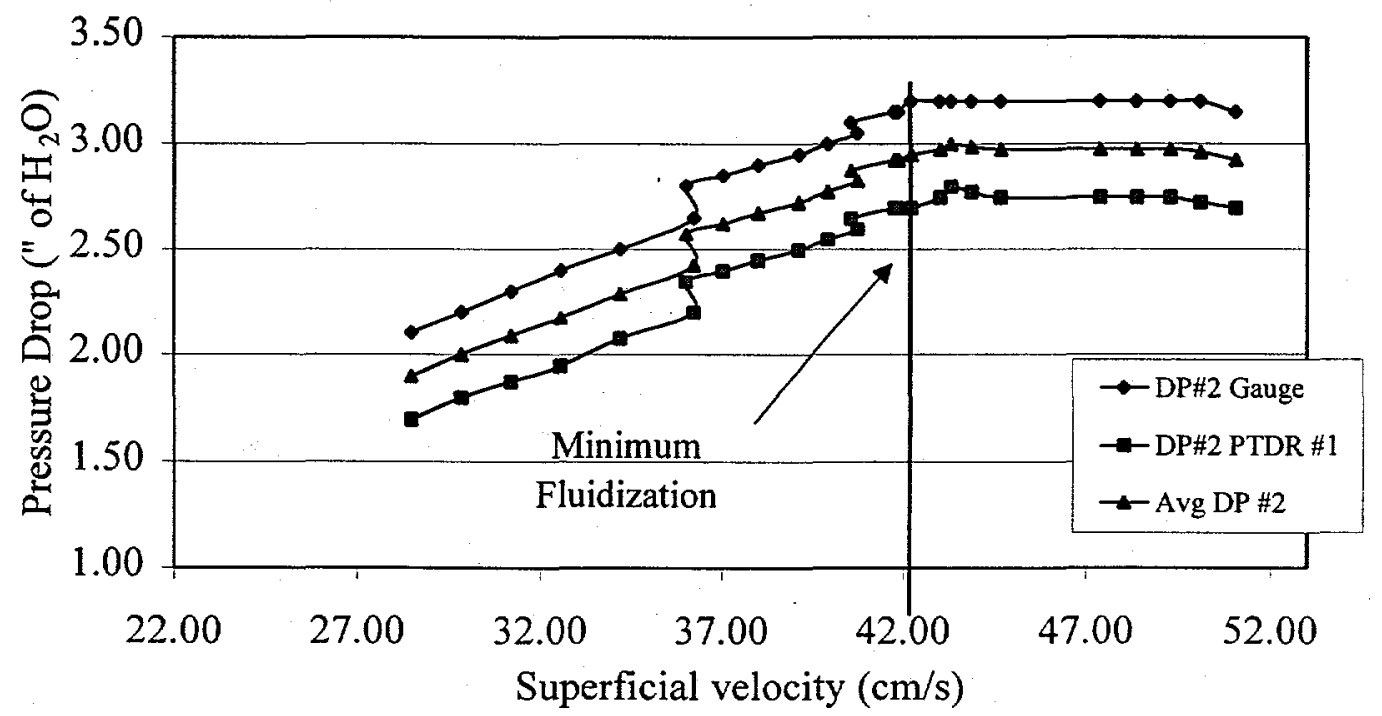


Salt was injected into the fluidized bed at either 0.25 or 0.5 gram increments. The amount of salt injected did not change the fluidization characteristics of the bed from one experiment to another. In all cases, the bed had collapsed after adding a total of 1.5 grams of $\mathrm{LiNO}_{3}$, and in many cases the bed collapsed immediately after adding the first 0.25 or 0.5 grams. The results of this section, seen in Table B.4, do not shed a favorable light on the potential for high temperature fluidization for nonporous glass spheres in the presence of molten salts.

\section{B.4d) Zirconia Experimental Design Matrix}

The next set of experiments was performed to see if changing the type of support (the density) and the type of salt (surface tension) affected the bed's ability to stay fluidized. The support consisted of 300 micron, spherical, non-porous zirconia particles generously donated by the TOSOH Company. $\mathrm{KNO}_{3}$ and $\mathrm{CsNO}_{3}$ were the salts for this set of experiments. $\mathrm{KNO}_{3}$ and $\mathrm{CsNO}_{3}$ both have higher melting points than $\mathrm{LiNO}_{3}$, around $350^{\circ} \mathrm{C}$ and $401^{\circ} \mathrm{C}$, respectively. This is the reason the higher temperature, $500^{\circ} \mathrm{C}$, for this simple experimental design matrix was chosen. The experimental design matrix for this set of experiments is shown in Figure B.29. The minimum fluidization curve for the zirconia particles at $500^{\circ} \mathrm{C}$ is found in Figure B.30. Due to the higher density of the zirconia particles, a 450 gram bed mass was used in order to have a sufficient bed height to achieve uniform fluidization. 
Table B.4 Amount of Salt Injected (grams) Causing $\mathrm{SiO}_{2}$ Fluidized Bed to Collapse.

\begin{tabular}{|c|c|c|c|c|}
\hline & \multicolumn{4}{|c|}{ Support } \\
\hline$\left(u-u_{m f}\right) \mathrm{cm} / \mathrm{s}$ & MIL \#5 Lot 1119 & A-055 & $\overline{\mathbf{A}-085}$ & A-110 \\
\hline 5 & $(0-0.5)$ & $(0-0.5)$ & $(0-0.5)$ & $(0.5-1.0)$ \\
\hline 15 & $(0-0.5)$ & $(0.5-1.0)$ & $(0-0.5)$ & $(1.0-1.5)$ \\
\hline 25 & $(0-0.5)$ & $(0-0.5)$ & $(0.5-1.0)$ & $(0-0.5)$ \\
\hline
\end{tabular}

Figure B.29 TOSOH Zirconia Spheres $(300 \mu \mathrm{m})$ Experimental Design Matrix.

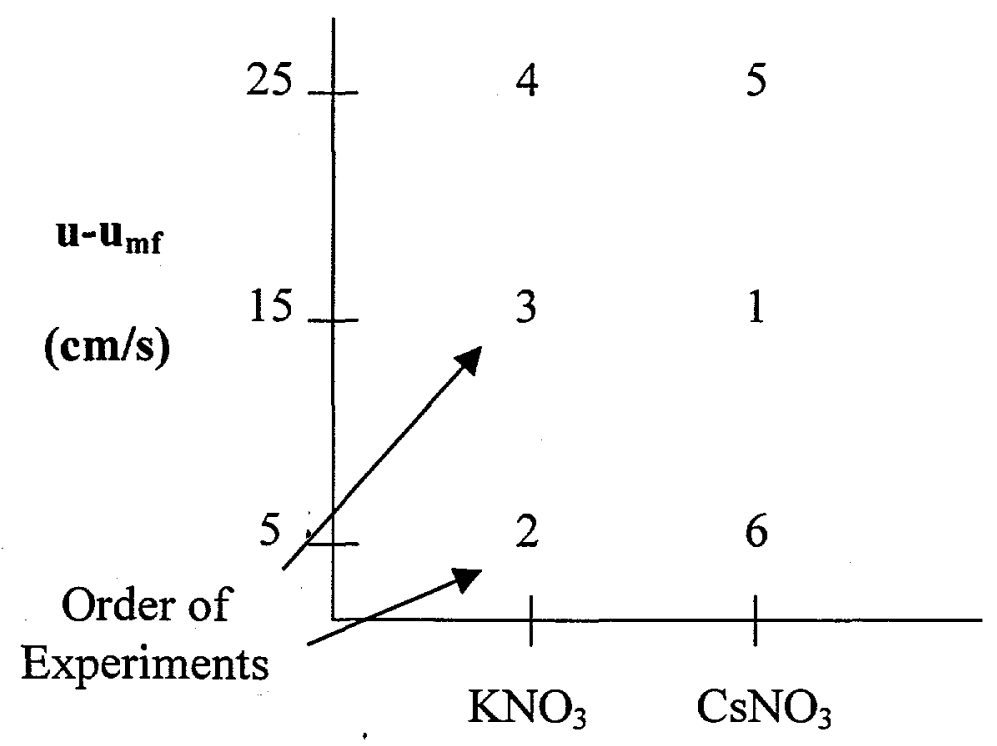


Theory predicts a pressure drop of $968 \mathrm{~Pa}\left(3.89\right.$ " of $\left.\mathrm{H}_{2} \mathrm{O}\right)$ across the bed above the minimum fluidization point. The experimental pressure drop above minimum fluidization is only around $846 \mathrm{~Pa}\left(3.4\right.$ " of $\left.\mathrm{H}_{2} \mathrm{O}\right)$. Since $\mathrm{ZrO}_{2}$ 's density is 2.5 times that of $\mathrm{SiO}_{2}$, the pressure drop occurs over a much shorter distance in the vertical direction. The pressure tube that measures the pressure directly above the distributor plate has holes drilled in the end of the tube. These holes do not start immediately above the distributor plate. The holes are in fact almost $2 \mathrm{~mm}$ above the distributor plate due to having the drill above the plug in the end of stainless steel tube. This artifact of the experimental apparatus did not have as pronounced an effect when using the $\mathrm{SiO}_{2}$ particles due to its lower density. The second reason for the lower pressure drop value stems from the small amount of $\mathrm{ZrO}_{2}$ support available for experimentation. Without a sufficient bed height, the gas does not get evenly distributed through the particles and part of the bed does not fluidize. These two reasons are proposed for the observed lower pressure drop. The experiments in - Figure B.29 were still run, in light of this disparity. The result of these experiments was similar to the previous section. All but one of the experiments saw the bed collapse shortly after adding the first 0.5 grams of salt. Table B. 6 contains the amount of salt added to the reactor prior to the bed collapsing. Bed collapse was assumed when a temperature decrease and sharp decline in the pressure drop across the bed of particles was observed. Again, fluidization in the presence of molten salts for this region of parameter space with non-porous particles does not appear feasible. 
Figure B.30 Minimum Fluidization Velocity for 450 grams of TOSOH Zirconia at $500^{\circ} \mathrm{C}$.

Minimum Fluidization Curve: Pressure Drop vs. Superficial Velocity

(Temp 500oC Support 450 gm off TOSOH $\mathrm{ZrO}_{2}, 300$ micron)

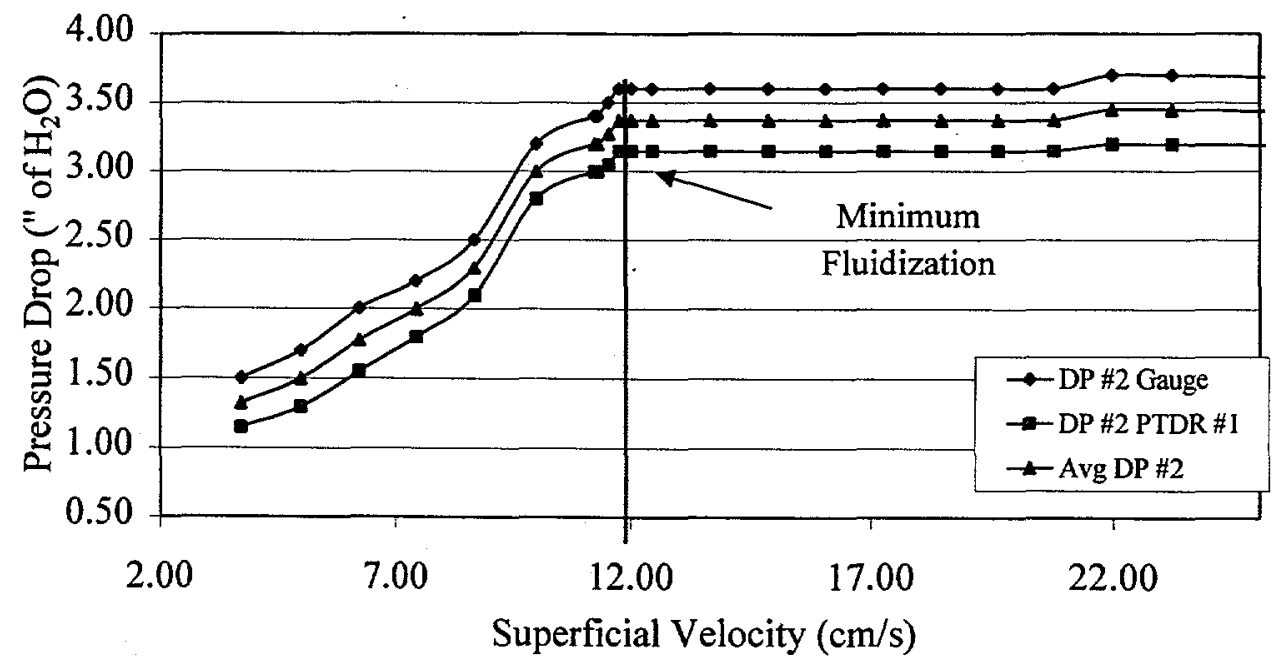

Table B.5 Amount of Salt Injected (grams) Causing $\mathrm{ZrO}_{2}$ Fluidized Bed to Collapse.

\begin{tabular}{|c|c|c|}
\hline & \multicolumn{2}{|c|}{ Salt } \\
\hline$\left(\mathbf{u}-\mathbf{u}_{\mathbf{m f}}\right) \mathbf{c m} / \mathbf{s}$ & $\mathbf{K N O}_{\mathbf{3}}$ & $\mathbf{C s N O}_{\mathbf{3}}$ \\
\hline $\mathbf{5}$ & $(0.5-1.0)$ & $(0-0.5)$ \\
\hline $\mathbf{1 5}$ & $(0-0.5)$ & $(0-0.5)$ \\
\hline $\mathbf{2 5}$ & $(0-0.5)$ & $(0-0.5)$ \\
\hline
\end{tabular}




\section{B.4e) Aqueous Salt Syringe Injector Experiments}

This set of experiments was completed using the silica particles listed in Table B.2. The experimental design matrix in Figure B. 24 was run again with the same procedures except for the method of salt injection. A saturated solution of $\mathrm{LiNO}_{3}$ was made. At room temperature, roughly 90 grams of $\mathrm{LiNO}_{3}$ is soluble in 1 Liter of water. $5 \mathrm{~mL}$ of salt solution was injected into the fluidized bed reactor. $5 \mathrm{~mL}$ of solution contains approximately 0.45 grams of salt. Water without salt present was injected into the fluidized bed prior to each run to act as a control. In each case, the water did not change the pressure drop across the bed. The temperature in the bed naturally decreased upon injection of the water, but with in a couple of minutes it would return to its original value. Only eight of the twelve experiments were completed in the experimental design matrix. The different method of injection did not produce tangible differences from the previous experiments. Table B.8 lists the total amount of salt injected that caused the bed to collapse. 


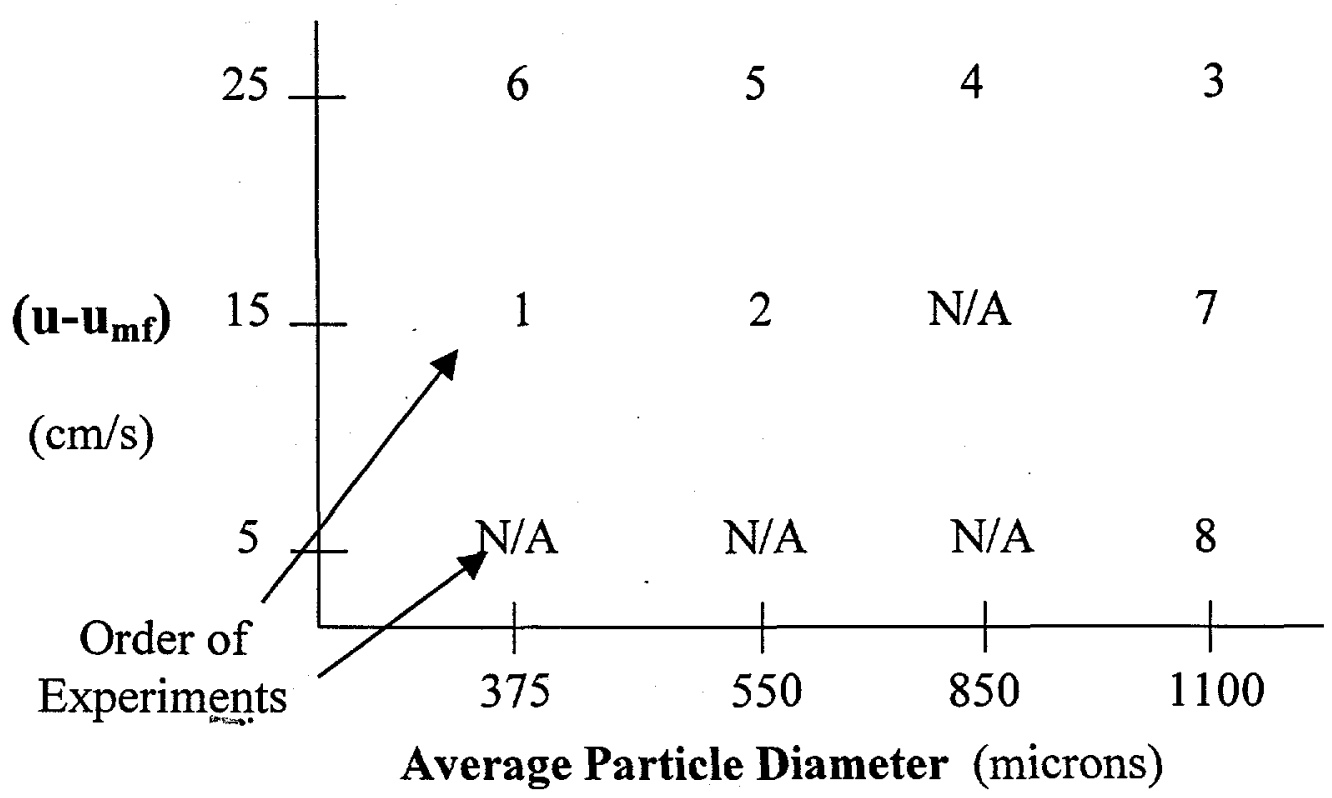

Figure B.31 Glass Ballotini (375-1100 $\mu \mathrm{m})$ with Aqueous Salt Injector Experimental Design Matrix.

Table B.6 Amount of Salt injected (grams) causing $\mathrm{SiO}_{2}$ Fluidized Bed to Collapse Using an Aqueous Syringe Injector.

\begin{tabular}{|c|c|c|c|c|}
\hline & \multicolumn{4}{|c|}{ Support } \\
\hline$\left(\mathbf{u}-\mathbf{u}_{\mathbf{m} \mathbf{f}}\right) \mathbf{~ c m} / \mathbf{s}$ & MIL \#5 Lot 1119 & $\mathbf{A - 0 5 5}$ & $\mathbf{A - 0 8 5}$ & $\mathbf{A - 1 1 0}$ \\
\hline 5 & $(0-0.45)$ & $(0.9-1.35)$ & $(0.45-0.9)$ & $(0.45-0.9)$ \\
\hline 15 & $(0-0.25)$ & $(0-0.45)$ & N/A & $(0.9-1.35)$ \\
\hline 25 & N/A & N/A & N/A & $(0-0.45)$ \\
\hline
\end{tabular}

